UNIVERSIDADE DE BRASÍLIA-UNB

FACULDADE DE AGRONOMIA E MEDICINA VETERINÁRIA-FAV

PROGRAMA DE PÓS-GRADUAÇÃO EM AGRONOMIA

\title{
CARACTERIZAÇÃO DE VARIEDADES DE CANA-SOCA SOB DIFERENTES REGIMES HÍDRICOS NO CERRADO
}

TESE DE DOUTORADO EM AGRONOMIA

PUBLICAÇÃO No 031D/2015

Brasília

Abril de 2015 
UNIVERSIDADE DE BRASÍLIA-UNB

FACULDADE DE AGRONOMIA E MEDICINA VETERINÁRIA-FAV

PROGRAMA DE PÓS-GRADUAÇÃO EM AGRONOMIA

\section{CARACTERIZAÇÃO DE VARIEDADES DE CANA-SOCA SOB DIFERENTES REGIMES HIIDRICOS NO CERRADO}

Francisco Rodolfo Junior

ORIENTADORA: Maria Lucrécia Gerosa Ramos

CO-ORIENTADOR: Walter Quadros Ribeiro Junior

TESE DE DOUTORADO EM AGRONOMIA

Brasília

Abril de 2015 


\title{
CARACTERIZAÇÃO DE VARIEDADES DE CANA-SOCA SOB DIFERENTES REGIMES HÍDRICOS NO CERRADO
}

\author{
FRANCISCO RODOLFO JUNIOR
}

\begin{abstract}
TESE DE DOUTORADO SUBMETIDA AO PROGRAMA DE PÓS-GRADUAÇÃO EM AGRONOMIA, COMO PARTE DOS REQUISITOS NECESSÁRIOS À OBTENÇÃO DO GRAU DE DOUTOR EM AGRONOMIA.
\end{abstract}

\section{APROVADA POR:}

Dra. Maria Lucrécia Gerosa Ramos - UnB/FAV

Orientadora - CPF 002.094.438-12/ lucrecia@unb.br

Dr. Marcelo Fagioli - UnB/FAV

Membro interno - CPF 729.409.306-78/ mfagioli@unb.br

Dr. Omar Cruz Rocha -Embrapa Cerrados

Membro externo - CPF 579.134.475-91/ omar.rocha@embrapa.br

Dr. André Ferreira Pereira -Embrapa Cerrados

Membro externo - CPF 898.027.301-06/ andré.ferreira@embrapa.br

Dr. Lineu Neiva Rodrigues

Membro externo - CPF 692.033.696-00/ lineu.rodrigues@embrapa.br

Brasília, 14 de abril de 2015 


\section{FICHA CATALOGRÁFICA}

Ficha catalográfica elaborada automaticamente,

com os dados fornecidos pelo(a) autor(a)

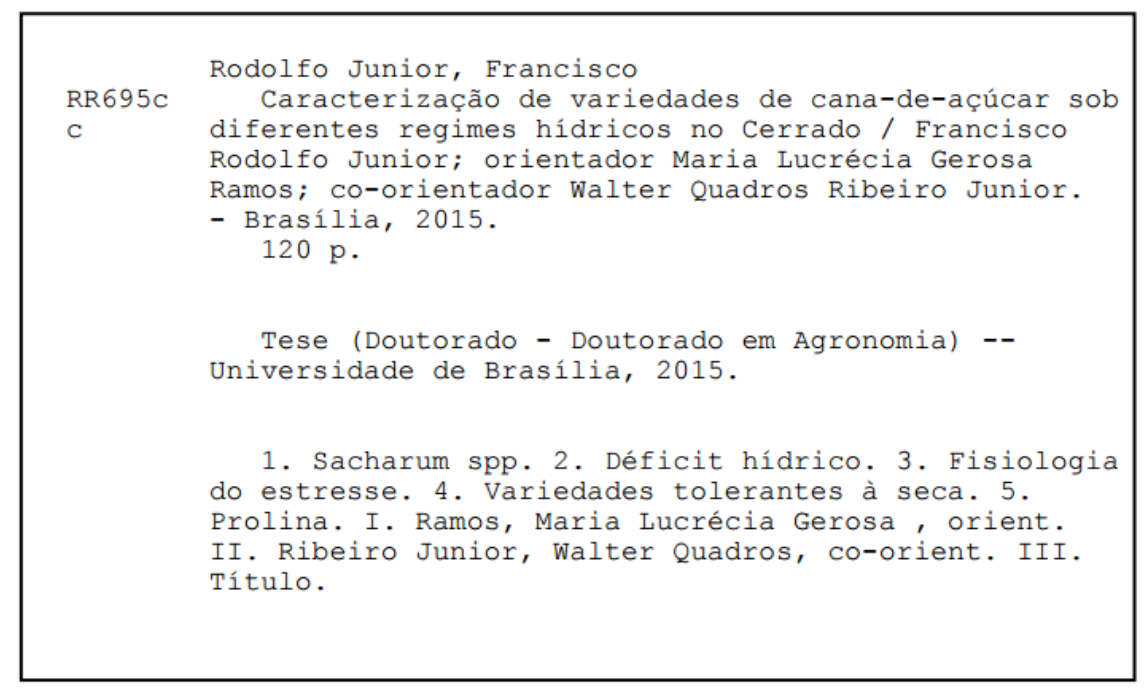

\section{REFERÊNCIA BIBLIOGRÁFICA}

RODOLFO JUNIOR, F. Caracterização de variedades de cana-soca sob diferentes regimes hídricos no Cerrado. 2015. 120f. Tese (Doutorado em Agronomia) - Faculdade de Agronomia e Medicina Veterinária, Universidade de Brasília, Brasília, 2015.

\section{CESSÃO DE DIREITOS}

NOME DO AUTOR: Francisco Rodolfo Junior

TÍTULO DA TESE DE DOUTORADO: Caracterização de variedades de cana-soca sob diferentes regimes hídricos no Cerrado.

GRAU: DOUTOR.

ANO: 2015

É concedida à Universidade de Brasília permissão para reproduzir cópias desta tese de doutorado e para emprestar ou vender tais cópias somente para propósitos acadêmicos e científicos. $\mathrm{O}$ autor reserva os outros direitos de publicação e nenhuma parte desta dissertação de mestrado pode ser reproduzida sem a autorização por escrito do autor.

Francisco Rodolfo Junior

CPF: 041.919.414-29

Endereço: Rua Dr Otávio Mariz 03, CEP 58819-000, Marizópois, PB, Brasil

Tel: 55+ 83 8180-8684, 89 9928-6783

Email: rodolfo@ufpi.edu.br, fcorodolfojunior@hotmail.com 
Llos meus pais, francisco Qodolfo de CKelo (in memonian) e francisca Osousa de CKelo. Alos meus irmãos, OHaria do Osocorro de Chelo, Qodolfo Phesma de CKelo, Qodrigo Qodolfo de Ckelo e Qafael Qodolfo de CKelo. As minhas queridas sobrinhas, Oricoly Abrantes de CKelo, Emily Ropes de Chelo, Osarah QKelly Gerönimo de Panvatho dkelo e Tasmin Gerônimo de Panvatho dKelo.

A todos os tios e primos; Alo meu amor, OHopra Allesandre de Eliveira pela força e compreensã̄o;

Enfim, a toda minha amada familia, meu presente divino, enviada por Deus para iluminar minha vida e ser meu porto seguro onde neles encontro a minha eterna fonte de inspiraçä́o. 


\section{AGRADECIMENTOS}

A Deus, pela sua bondade infinita, pelo dom da vida que nos concede, pela felicidade e família que tenho.

A minha família, pelo grande apoio e incentivo, principalmente nos momentos de dificuldades encontradas no decorrer de nossas vidas.

À Universidade de Brasília (UnB), pela realização do sonho em me tornar Doutor em Agronomia.

A Profa. Dra. Maria Lucrécia Gerosa Ramos, pela grande orientação, apoio, amizade, lições e experiências de viva.

Ao Dr. Walter Quadros Ribeiro Junior, pela dedicação e compreensão, assim como pelos ensinamentos e contribuição para este trabalho.

Aos amigos Fábio Pedro da Silva Batista e Cristiane Andréa de Lima pela participação e colaboração na condução do experimento.

À Embrapa Cerrados pela parceria na infra-estrutura de pesquisa.

Aos funcionários e professores do Programa de Pós-Graduação em Agronomia da FAV-UnB.

Aos grandes amigos contemporâneos de Pós-Graduação e Colina, e a todos que participaram de forma direta ou indireta da minha vida na UnB.

Por fim, à todos que contribuíram de alguma forma para a realização deste trabalho. 


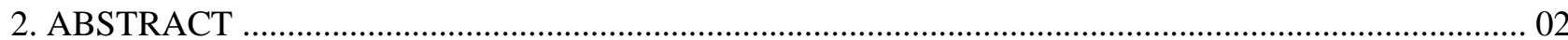

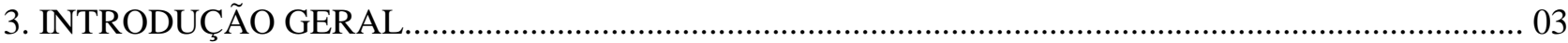

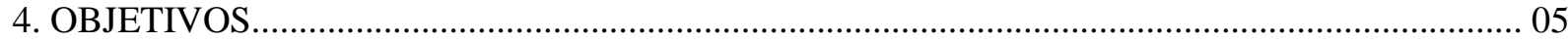

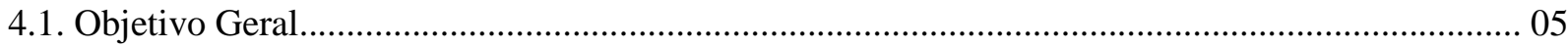

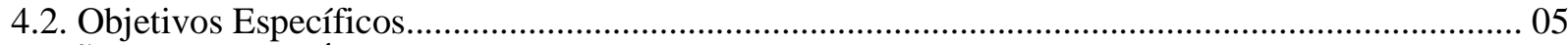

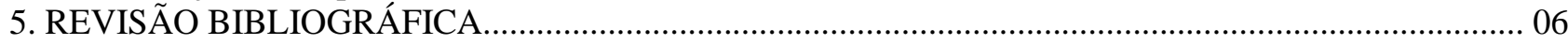

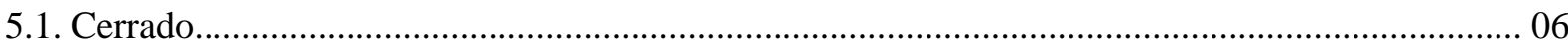

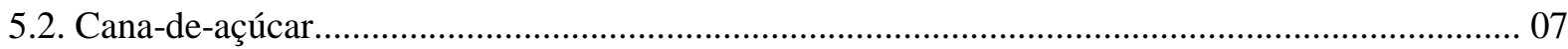

5.2.1. Histórico, importância econômica e produção da cana-de-açúcar no Brasil............................... 08

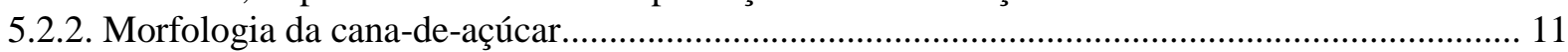

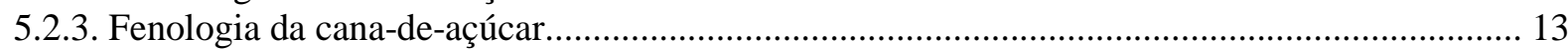

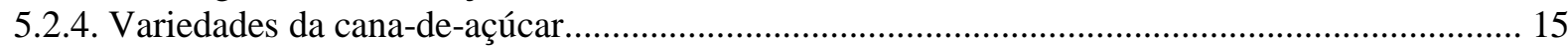

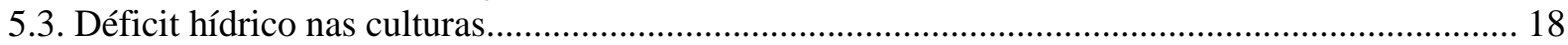

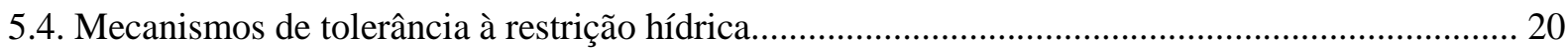

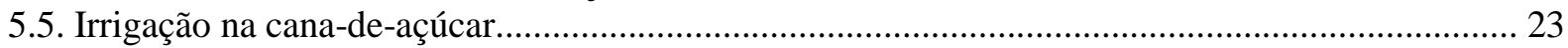

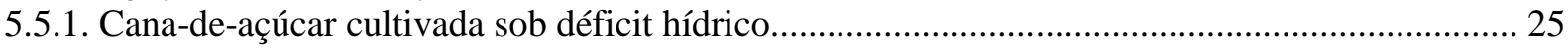

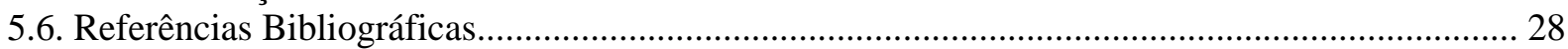

6. CAPÍTULO I - RESPOSTAS BIOMÉTRICAS DE VARIEDADES DE CANA-DE-AÇÚCAR DE

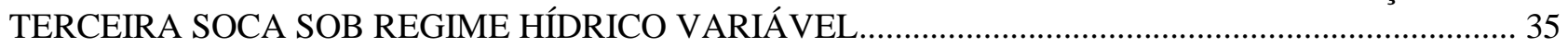

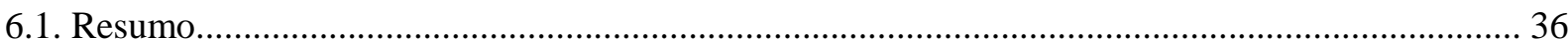

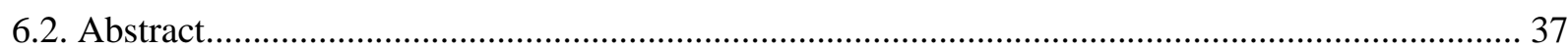

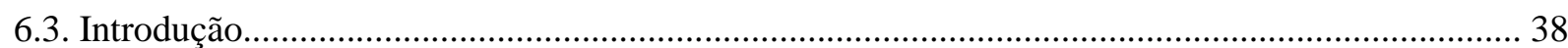

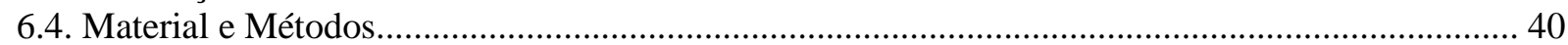

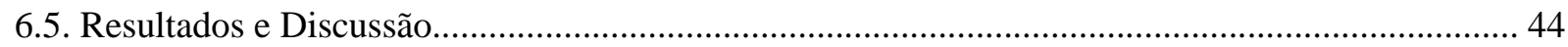

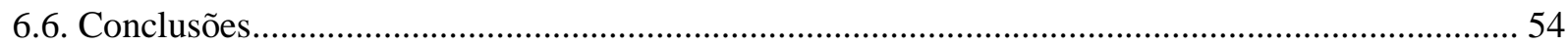

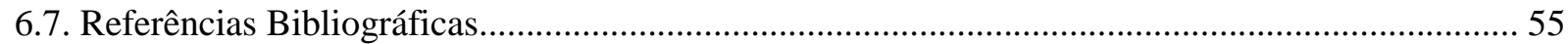

7. CAPÍTULO II - PRODUTIVIDADE AGRÍCOLA E QUALIDADE INDUSTRIAL DE VARIEDADES

DE CANA-DE-AÇÚCAR DE TERCEIRA FOLHA SOB REGIME HÍDRICO VARIÁVEL....................... 58

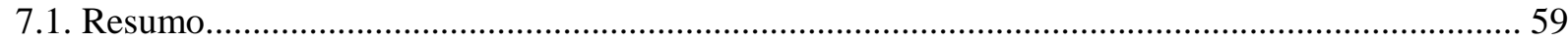

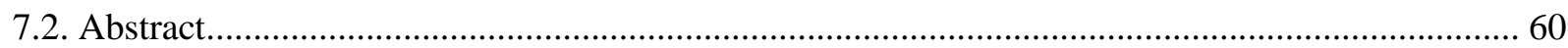

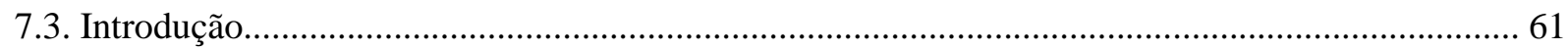

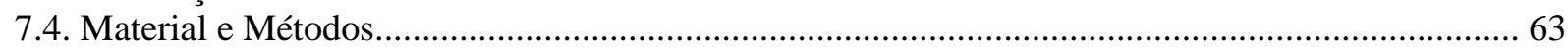

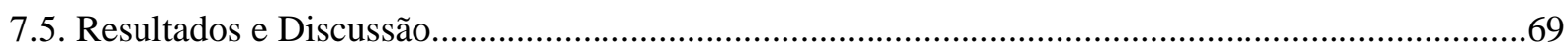

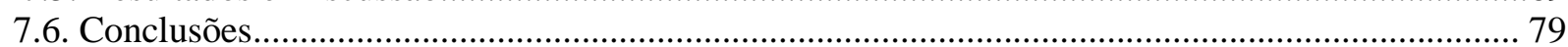

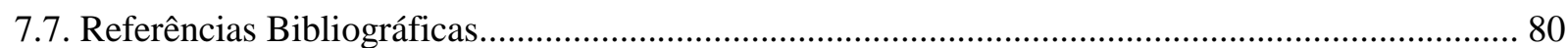

8. CAPÍTULO III - RESPOSTAS FISIOLÓGICOS EM VARIEDADES DE CANA-DE-AÇÚCAR

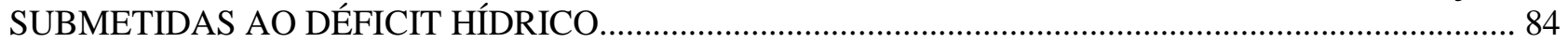

8.1. Resumo

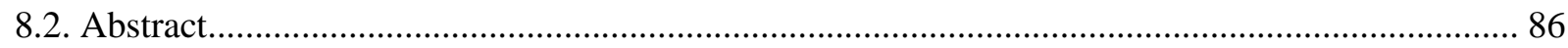

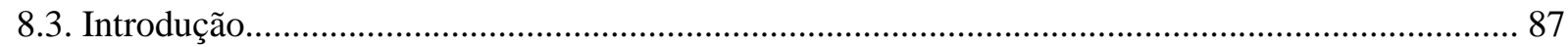

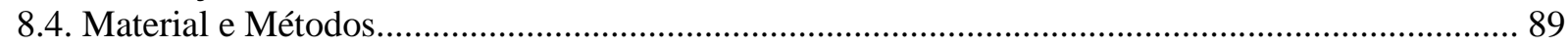

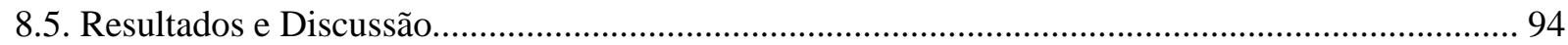

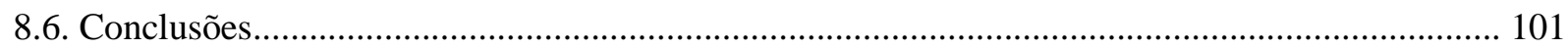

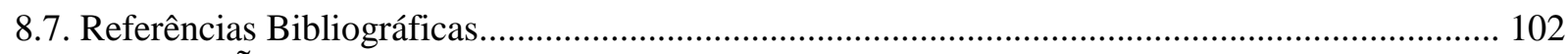

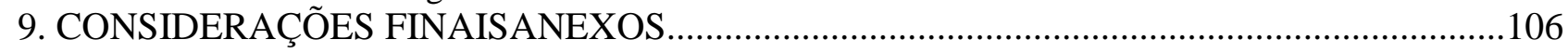

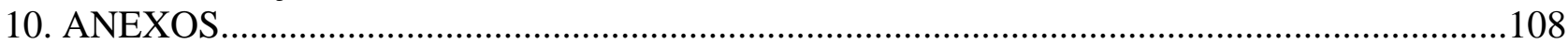




\section{RESUMO GERAL}

A cana-de-açúcar é uma planta $\mathrm{C} 4$ que possui boa adaptabilidade em regiões tropicais e subtropicais, em diferentes tipos de solos e condições climáticas, destacando a sua grande importância econômica no cenário mundial atual, por ser matéria prima de produtos como o álcool e o açúcar e subprodutos. A deficiência hídrica é um dos principais fatores que limitam a produção da cana-de-açúcar. O objetivo deste estudo foi caracterizar variedades de cana-soca sob diferentes regimes hídricos no Cerrado brasileiro. O experimento foi conduzido em uma área de 0,36 hectares, localizada na EMBRAPA Cerrados, próxima a Planaltina-DF. O delineamento experimental utilizado foi em blocos ao acaso com três repetições em parcelas subdivididas; cada variedade constituía uma parcela e os diferentes regimes hídricos, irrigado e sequeiro, as subparcelas. No experimento a irrigação foi aplicada conforme o sistema Line Source Sprinkler System, modificado de forma que a lâmina de água aplicada na cultura descresse do centro para as extremidades da área. Foram avaliadas características biométricas: diâmetro médio do colmo (DMC), altura média do perfilho (AMP), número de folhas verdes completamente abertas (NFVA), comprimento e largura da folha $+3(\mathrm{C}+3$ e $\mathrm{L}+3$, respectivamente), índice de área foliar (IAF) e área foliar (AF); características de produção: produtividade de colmos e qualidade do caldo : comprimento do entrenó (CE), peso do colmo (PC), número de perfilhos por hectare e produtividade; tecnológicos do caldo: ${ }^{\circ}$ Brix do caldo, Pol do caldo (teor de sacarose), pureza (PZA), AR (teor de açúcares redutores do caldo), ARC (açúcares redutores da cana), fibras, Pol da cana (PCC), açúcares totais recuperáveis (ATR) e o valor da megagrama da cana $(\mathrm{VMgC})$; e características fisiológicos: prolina livre na folha; e trocas gasosas foliares: transpiração $(\mathrm{E})$, condutância estomática $\left(\mathrm{g}_{\mathrm{s}}\right)$, fotossíntese líquida (A), carboxilação (EC); e aumento da eficiência intrínseca do uso da água (EIUA) e a concentração foliar de clorofilas ( $a, b$ e total); Os dados foram submetidos à análise de variância e regressão, e as médias comparadas pelo teste de Tukey a p<0,05. A variedade $R B 867515$ foi a que apresentou maiores valores biométricos de DMC, AMP, C+3 e L+3, tanto em cultivo irrigado como em sequeiro; observou-se que houve redução nos números de NFVA, e aumento do NFE e NFM por perfilhos quando as variedades foram cultivadas em sequeiro; as variedades RB835486 e RB867515 se mostraram melhor adaptadas à restrição hídrica ocorrida até os 137 DAC para os tratamentos em sequeiro. A variedade RB867515 e a RB855156 foram as que obtiveram maior produtividade, com 174,99 e $148,10 \mathrm{Mg} \mathrm{ha}^{-1}$, respectivamente. A cana-de-açúcar cultivada com irrigação equivalente a $75 \%$ da ETc não proporcionou diferença significativa para a qualidade industrial das variedades RB835486, RB855156 e RB867515 em relação ao cultivo em sequeiro (0\% da ETc). Não houve diferença significativa para os valores do teor de açúcares redutores (AR), açúcares redutores da cana (ARC) e a pureza do caldo (PZA) entre as variedades RB835486, RB855156 e RB867515. As variedades de cana-de-açúcar RB835486, RB855156 e RB867515 cultivadas em sistema de sequeiro apresentaram redução na transpiração $(\mathrm{E})$, condutância estomática $\left(\mathrm{g}_{\mathrm{s}}\right)$, fotossíntese líquida (A), carboxilação (EC), clorofila $a$ (Clo $a$ ), clorofila total (Clo $a+b)$; e aumento da eficiência intrínseca do uso da água (EIUA).

Palavras-chave: Saccharum spp. L., déficit hídrico, fisiologia do estresse, variedades tolerantes à seca. 


\section{GENERAL ABSTRACT}

The sugarcane is a $\mathrm{C} 4$ plant that has good adaptability in tropical and subtropical regions, in different types of soils and climatic conditions, highlighting its great economic importance in the current world scenario, because it is raw material for products such as alcohol and sugar and byproducts. Water stress is a major factor limiting the production of cane sugar. The objective of this study was to characterize ratoon varieties under different water regimes cultived in the Brazilian Cerrado. The experiment was conducted in an area of 0.36 hectares, located in EMBRAPA Cerrado, near Planaltina-DF. The experimental design was a randomized block design with three replications in a split plot; each variety was a plot and the different water regimes, irrigated and rainfed, the subplots. In the experiment the irrigation was applied as Line Source Sprinkler System system, modified so that the amount of water applied to disbelieve culture from the center to the edges of the area. Biometric characteristics were evaluated: average diameter of the stem (DMC), average stem height (AMP), number of wide open green leaves (NFVA), length and width of the sheet $+3(\mathrm{C}+3$ and $\mathrm{L}+3$, respectively), leaf area index (LAI) and leaf area (LA); production characteristics: sugarcane yield and quality of the broth: length of internode (EC), stem weight (PC), tiller number per hectare productivity; processing the juice: ${ }^{\circ}$ Brix of the juice, the juice Pol (Sucrose content), purity (PZA), AR (content of reducing sugars of the juice), ARC (reducing sugarcane), fibers, cane Pol (PCC), sugars total recoverable (ATR) and the value of megagram sugarcane $(\mathrm{VMgC})$; and physiological characteristics: free proline in leaf; and leaf gas exchange: transpiration (E), stomatal conductance $\left(\mathrm{g}_{\mathrm{s}}\right)$, net photosynthesis $(\mathrm{A})$, carboxylation $(\mathrm{CE})$; and increased intrinsic water use efficiency (EIUA) and leaf chlorophyll concentration $(a, b$ and total); Data were subjected to analysis of variance and regression and the means compared by Tukey test ap $<0.05$. The RB867515 variety showed the largest biometric values of DMC, AMP, $\mathrm{C}+3$ and $\mathrm{L}+3$ in both irrigated and rainfed; it was observed that there was a reduction in the number of NFVA and increasing the SNF and NFM per tiller where varieties were grown in upland; the RB835486 and RB867515 varieties proved better suited to water restriction occurred until 137 CAD for treatments in upland. The RB867515 and RB855156 variety were the ones that had higher productivity, with 174.99 and $148.10 \mathrm{Mg} \mathrm{ha}^{-1}$, respectively. The sugarcane grown with irrigation equivalent to $75 \%$ of ETc not provided significant difference to the quality of industrial RB835486 varieties, RB855156 and RB867515 concerning cultivation in rainfed (0\% ETc). There was no significant difference in the values of reducing sugars (AR), reducing sugarcane (ARC) and the purity of the broth (PZA) between varieties RB835486, RB855156 and RB867515. The varieties of sugarcane RB835486, RB855156 and RB867515 grown in rainfed system had reduced transpiration (E), stomatal conductance $\left(\mathrm{g}_{\mathrm{s}}\right)$, net photosynthesis (A), carboxylation (CE), chlorophyll a (Clo $a$ ) chlorophyll (Clo $a+b)$; and increased intrinsic water use efficiency (EIUA).

Keywords: Saccharum spp. L., water deficit, stress physiology, drought-tolerant varieties. 


\section{INTRODUÇÃO GERAL}

A preocupação com o aumento do uso de combustíveis fósseis vem causando preocupação com os efeitos danosos ao clima global. Nesse sentido, comunidades internacionais procuram estudar e atingir metas rígidas para a redução da emissão dos gases que agravam o efeito estufa, considerados, de acordo com a maioria das investigações científicas, como causas antropogênicas do aquecimento global. Com o Protocolo de Kyoto surgiu o Mecanismo de Desenvolvimento Limpo (MDL), que é um dos mecanismos de flexibilização para auxiliar o processo de mitigação das emissões de gases do efeito estufa (GEE) ou de captura de carbono (seqüestro de carbono), por parte dos países envolvidos no acordo internacional. Para o Brasil, em especial, o MDL pode ser muito interessante já que aproveita o seu grande potencial para a produção de energia limpa, e possibilita que o país desempenhe papel importante no cenário internacional (MENEGUELLO; CASTRO, 2007; MOREIRA et al., 2008).

Com a proposta do MDL, o Brasil teve o início de numa nova fase de crescimento para o setor sucroalcooleiro, que foi favorecida pelo aumento do uso de biocombustíveis, sendo considerado um dos líderes em projetos de créditos de carbono registrados na ONU, onde a grande maioria desses projetos está relacionada com a geração de energia a partir da cana-de-açúcar (Saccharum spp. L.), sendo uma das melhores opções dentre as fontes de energia renovável, proporcionando o aumento das lavouras de cana-de-açúcar, favorecendo a sua posição de importância no cenário agrícola do país (MAULE et al., 2001; MORAES, 2007). Atualmente, o Brasil é o principal produtor de cana-de-açúcar e tem se destacado por ser o país que detém a liderança na tecnologia de produção, onde do total de açúcar que é produzido no mundo, 55\% é proveniente do Brasil (IBGE, 2014).

Com o recente desafio da exploração canavieira na região Centro-Oeste do país, onde a tendência de crescimento na produção continua sendo observada nas safras atuais (CONAB, 2014), e com quase sua totalidade em áreas de Cerrado, a regularidade das chuvas e a disponibilidade hídrica deve ser cuidadosamente observada, exatamente pelo longo período de estiagem característico marcante do Bioma (SILVA et al., 2008b). Isso faz com que as características climáticas sejam um fator determinante na escolha das variedades para o plantio, haja vista que o Cerrado brasileiro, possui características climáticas peculiares, com um período chuvoso e um seco bem definidos (SANO et al., 2008), o que pode provocar efeitos danosos ao cultivo da cana-deaçúcar, caso os períodos de maior necessidade hídrica da cultura não coincidam com a estação chuvosa do Bioma. Dessa forma, o déficit hídrico é uma das principais causas da redução da produtividade nos canaviais, e pesquisas para entender claramente os mecanismos de respostas da cultura a esse tipo de estresse é uma demanda imediata (MACÊDO et al., 2012). 
A necessidade hídrica no cultivo da cana-de-açúcar é variável de acordo com a fase fenológica (DOORENBOS; KASSAM, 1979), o que possibilita um manejo de irrigação e época de plantio mais eficiente, evitando-se perdas na produtividade por ocorrer estresse hídrico em fases fenológicas sensíveis, afetando na produção de biomassa e acumulação de sacarose (DANTAS NETO et al., 2006; MOURA et al., 2014), sendo essas características consideravelmente diferentes entre os diferentes genótipos (SILVA et al., 2008b). Por isso, para atingir eficiência satisfatória no sistema produtivo, assim como a sustentabilidade econômica da atividade sucroalcooleira, o uso de lâminas de irrigação adequadas à cada fase fenológica passa a ser o ponto crucial a fim de evitar o estresse hídrico na cultura nos períodos considerados críticos de seu crescimento e desenvolvimento, viabilizando o aumento da produtividade e, ao mesmo tempo potencializando o retorno econômico do setor e a longevidade do canavial (GAVA et al., 2011; SILVA et al., 2012).

A escolha da variedade de cana-de-açúcar é outra etapa fundamental para se obter sucesso no cultivo da cultura. As diferentes características agrícolas das áreas de cultivo no Brasil e as variações do material genético utilizado, junto com um sistema de produção eficiente, pode elevar a eficiência produtiva do setor sucroalcooleiro para o ambiente de produção que é encontrado no Cerrado, ou seja, variedades mais tolerantes à seca, para que o período de estiagem longa não seja prejudicial ao desenvolvimento e produtividade canavieira. A ampla oferta de material genético pode favorecer a escolha de uma variedade que seja adaptada às condições específicas de cada sistema de produção, assim como os vários ambientes que podem ser encontrados nas áreas produtivas do Brasil, fazendo com que se produza uma matéria prima com maior qualidade para a produção de açúcar e álcool. 


\section{OBJETIVOS}

\subsection{Objetivo geral}

Caracterizar variedades de cana-soca sob diferentes regimes hídricos cultivadas no Cerrado brasileiro.

\subsection{Objetivos específicos}

a) Caracterizar biometricamente as variedades da cana-de-açúcar, submetidas a diferentes regimes hídricos.

b) Determinar a produtividade agrícola e a qualidade tecnológica do caldo das variedades da cana-de-açúcar, submetidas a diferentes regimes hídricos.

c) Caracterizar fisiologicamente as variedades da cana-de-açúcar, submetidas a diferentes regimes hídricos. 


\section{REVISÃO BIBLIOGRÁFICA}

\subsection{O Cerrado}

Cerrado é um Bioma do tipo biócoro savana que ocorre predominantemente na região central do Brasil, sendo atualmente o segundo maior entre os seis grandes Biomas do país, abrangendo 15 estados da federação e ocupando uma área equivalente a $2.036 .448 \mathrm{~km}^{2}$, que representa $22 \%$ do território brasileiro (SANO et al., 2008). Este Bioma localiza-se entre $5^{\circ}$ e $20^{\circ}$ de latitude Sul e de $45^{\circ}$ a $60^{\circ}$ de longitude Oeste, fazendo limite com a Mata Atlântica, a Floresta Amazônica, a Caatinga e o Pantanal, e a sua vegetação predominante apresenta semelhanças ecológicas e fisionômicas quando comparada a outros Biomas tropicais, como na América Tropical, África e Austrália (IBRAM, 2014; BRASIL, 2014). O cerrado é a savana que possui a maior biodiversidade do mundo e a sua área contínua está presente nos Estados de Goiás, Tocantins, Mato Grosso, Mato Grosso do Sul, Minas Gerais, Bahia, Maranhão, Piauí, Rondônia, Paraná, São Paulo e Distrito Federal, além dos encraves no Amapá, Roraima e Amazonas. Neste espaço territorial encontram-se as nascentes das três maiores bacias hidrográficas da América do Sul (Amazônica/Tocantins, São Francisco e Prata), o que resulta em um elevado potencial aqüífero e favorece a sua biodiversidade (BRASIL, 2014).

Os solos dominantes no Cerrado são, em sua maioria, classificados como Latossolos (45,7\%), além de Neossolos Quartzarênicos (15,2\%), Podzólicos (15,1\%) e Plintossolos (9,0\%), representando $85 \%$ do total da área do Bioma, sendo os demais classificados como Litossolos (GOMES et al., 2004). Desse modo, pode se afirmar que de maneira geral, os solos do Cerrado são antigos e intemperizados, com baixa CTC, profundos, baixa densidade, bem estruturados, alta estabilidade de agregados, alta permeabilidade, boa aeração e baixa resistência à penetração (GOEDERT, 1980; KLUTHCOUSKI et al., 2003). São solos fisicamente favoráveis ao uso de implementos agrícolas quando bem manejados, pois com o cultivo e o manejo não adequados, ocorre aumento da densidade e, como consequiência, maior resistência à penetração das raízes e menor permeabilidade da água no perfil, provocando riscos à erosão (LUCHIARI JÚNIOR et al., 1987). No entanto, quimicamente precisam de atenção especial, principalmente devido à baixa fertilidade natural e aos teores de matéria orgânica desses solos, que passam a desempenhar papel importante na sua fertilidade e elevação da capacidade de troca catiônica CTC (GOEDERT, 1980; MIELNICZUK, 2008).

O clima do Cerrado é classificado como sendo do tipo Tropical Estacional com períodos bem definidos de chuva e seca (SILVA et al., 2001), com considerável variação climática pela sua grande distribuição e extensão no território brasileiro. O clima do Cerrado brasileiro é diretamente afetado por fatores como a ação conjunta da dinâmica ou sistemas da atmosfera que afetam toda a 
América do Sul durante o ano e confere ao Cerrado características climáticas em que se obtém duas estações bem definidas (SANO et al., 2008).

A estação chuvosa inicia-se entre os meses de setembro e outubro e se estende até março e abril, destacando-se os meses de novembro, dezembro e janeiro como os que apresentam a maior média mensal de precipitação. O período de seca é bem definido, ocorrendo a redução e/ou até eliminação total de chuvas, que podem durar meses seguidos sem registros de precipitação. A falta prolongada de chuva provoca período de estresse hídrico intenso nos cultivos agrícolas (SANO et al., 2008).

Em meados da década de 1970, o Cerrado mesmo sendo o Bioma com a maior biodiversidade biológica do planeta, possuia pouca importância no cenário econômico do país. Foi a partir dessa década que por esforços da iniciativa privada e do Estado, iniciou-se a implantação agrícola nas áreas de Cerrado, sendo implantado o que seria uma agricultura moderna, para consolidar a agricultura nessas áreas, até então vistas como áreas em atraso econômico. Essa justificativa e a de integração das áreas de Cerrado com o restante do país motivou a implantação e modernização da agricultura, a urbanização do Bioma Cerrado que passou a integrar à economia nacional e internacional, passando a constituir o "celeiro do Brasil" (MATOS; PESSÔA, 2014). Com isso, nas últimas décadas, o Cerrado passou a ser o principal responsável no agronegócio brasileiro, sendo conhecido como a região mais promissora do país para a produção de gado e monoculturas (soja, milho, cana-de-açúcar, algodão), além da agroindústria e da indústria (CHAVEIRO, 2008; MATOS; PESSÔA, 2014).

Atualmente, o Cerrado brasileiro possui grande importância para o desenvolvimento e expansão do agronegócio brasileiro, sendo considerado como a última fronteira agrícola brasileira, como também a maior do mundo. Apesar dos benefícios socioeconômicos provenientes da implantação agrícola no Bioma, ainda é considerado desconhecido pela sua rica diversidade biológica. Sendo assim, é fundamental o aprofundamento nos estudos para o melhor conhecimento desse ambiente que é o Cerrado brasileiro, para que assim se possa estabelecer sistemas produtivos que sejam sustentáveis e gerar o mínimo de impactos negativos nas áreas de produção, e ao mesmo tempo, atingir o máximo de benefícios fornecidos pelo Cerrado (SANO et al., 2008).

\subsection{A Cana-de-açúcar}

A cana-de-açúcar (Saccharum officinarum L.) é uma planta semiperene da família Poaceae. É originária da Oceania - Ilha de Papua, na Nova Guiné Ocidental, onde a mesma inicialmente foi utilizada como planta ornamental e ainda se desenvolve naturalmente em meio silvestre; sendo a Ásia (Índia e China) também relatadas como possíveis locais de origem da cultura (BASTOS, 1987). É classificada em: Divisão - Manoliophyta, Classe - Magnoliopsida, Ordem - 
Graminales, Família - Poaceae e Gênero - Saccharum (CRONQUIST, 1981). Atualmente se cultiva um híbrido interespecífico que recebe a denominação Saccharum spp. L. (FERNANDES, 1990).

É uma planta, que possui o metabolismo fotossintético tipo $\mathrm{C} 4$, com eficiência na transformação de energia luminosa em energia química, respondendo de forma direta ao aumento de radiação, resultando em aumento expressivo na produção e, conseqüentemente, maior armazenamento de sacarose nos tecidos do colmo. A cana-de-açúcar também tem conquistado seu espaço na função ambiental, por ser conhecida pela sua eficiência na fixação do $\mathrm{CO}_{2}$ e no uso de água e de nutrientes, portanto, indicada para regiões tropicais e contribuindo significativamente para a fixação do $\mathrm{CO}_{2}$ atmosférico e à redução na taxa de aquecimento global (TEJERA et al., 2007).

Estima-se que com a produtividade atual de aproximadamente $74 \mathrm{Mg} \mathrm{ha}^{-1}$ de colmos, contendo aproximadamente $25 \%$ de matéria seca com $45 \%$ de carbono, representando $39 \mathrm{Mg} \mathrm{ha}^{-1}$ de matéria seca (colmo, palha, folhas e raízes, com 18,5;8,71;3,26 e 8,71 $\mathrm{Mg} \mathrm{ha}^{-1}$, respectivamente) pode chegar a $17,64 \mathrm{Mg} \mathrm{ha}^{-1}$ de $\mathrm{C}$ fixado $\left(8,33 ; 3,92 ; 1,47 ; 3,92 \mathrm{Mg} \mathrm{ha}^{-1}\right.$, respectivamente), o que representa que para o Brasil, com uma área plantada com cana-de-açúcar equivalente a 8,7 milhões de ha (safra 2013/2014), chegaria a 153,46 Mt de C fixado na matéria seca da cana-de-açúcar anualmente, correspondente a um aumento de 193,5\% comparado aos dados da safra 1999/2000 (RESENDE et al., 2001).

Para que se tenha maior eficiência produtiva, a cana-de-açúcar requer solos corrigidos e equilibrados, portanto, não se adapta à condição de cultura pioneira (CÂMARA; OLIVEIRA, 1993; WIEDENFELD, 2004; TEJERA et al., 2007). Essa conhecida eficiência fotossintética e acúmulo de sacarose faz com que a cana-de-açúcar seja uma cultura com uma relevante importância econômica, principalmente em países com condições climáticas semelhantes ao Brasil (TEJERA et al., 2007). Além disso, é uma cultura adaptada aos climas tropical e subtropical e necessita de um grande volume de água durante o seu ciclo produtivo e essa necessidade hídrica se potencializa nas fases iniciais do cultivo, onde predominam o crescimento vegetativo da cultura (WIEDENFELD, 2004; TEJERA et al., 2007).

\subsubsection{Histórico, importância econômica e produção da cana-de-açúcar no Brasil}

A exploração da cana-de-açúcar no mundo teve início na sua expansão com as grandes viagens náuticas, onde imigrantes disseminavam a cultura por ilhas no Sul do Pacífico, na Indochina, no Arquipélago da Malásia e em Bengala. No entanto, só na Índia que a cana-de-açúcar tem seus primeiros registros como sendo explorada para a produção de açúcar (MIRANDA, 2008). De acordo com o mesmo autor, em meados do ano de 1532, as primeiras mudas da cultura, foram introduzidas no Brasil por Martim Afonso de Souza, e estas eram provenientes da ilha da Madeira e da Região Autônoma dos Açores, que são arquipélagos situados no Oceano Atlântico a Sudoeste e 
Nordeste, respectivamente, da costa Portuguesa. Esses arquipélagos possuem situação climática semelhante ao Brasil, fato este que provavelmente incentivou o início do plantio no país (CHAVES et al., 2003).

No período imperial, com a introdução da cultura no Brasil, a produção de açúcar era basicamente no Nordeste, principalmente nos Estados do Pernambuco e Bahia, onde, durante muito tempo, a exploração canavieira não tinha impacto no cenário econômico. Mas, foi com a consolidação do mercado nacional e internacional que, aos poucos, a produção sucroalcooleira foi mudando para o Estado de São Paulo, onde estavam concentrados os principais mercados consumidores. É lá onde se tem registros da construção dos primeiros engenhos no Brasil, hoje atual município de São Vicente. Somente em meados do século XVIII, impulsionada pelo declínio na produção do café, e incentivos financeiros e vantagens de infra-estrutura, os antigos cafeicultores e novos investidores, passaram a instalar usinas para o processamento da cana-de-açúcar. A partir desse momento histórico, a produção de açúcar em São Paulo teve destaque, e inúmeros engenhos se instalaram nas regiões de Campinas, Itu, Moji Guaçu, Piracicaba e ao Norte do Estado, nas vizinhanças de Ribeirão Preto, denominado "quadrilátero do açúcar", onde o centro era o atual município de Piracicaba (RAMOS, 1999).

No fim do século XVIII e início do século XIX, agricultores consideravam que as suas terras no entorno de Piracicaba-SP, não eram tão adequadas à exploração da cafeicultura, sendo que na mesma região havia se instalado três dos maiores engenhos da região centro do Estado e usinas de grande porte, o que tornou a região conhecida como a maior produtora de açúcar do Estado de São Paulo. Alguns anos mais tarde, por volta de 1910, com o grande crescimento econômico do Estado de São Paulo, os grandes engenhos de aguardente de cana-de-açúcar tornaram-se usinas e passaram a produzir em grande escala, o que deu origem aos grandes e tradicionais grupos produtores, que estão em atividade até os dias atuais (SZMRECSÁNYI, 1979; MOZAMBANI et al., 2006). Desde então, as indústrias que utilizam a cana-de-açúcar como matéria prima, se multiplicaram e se modernizaram, desempenham papel de extrema importância à economia do Brasil, tornando o país com maior produção de açúcar e álcool do mundo, implantando em larga escala um combustível alternativo derivado da cana-de-açúcar (CHAVES et al., 2003; SILVA et al., 2012).

Além da importância ambiental, devido à sua eficiência na fixação de $\mathrm{CO}_{2}$, a importância econômica da cana-de-açúcar para os países produtores, é pelo fato da cultura ser matéria prima básica para diversos produtos industrializados, dos quais de destacam o açúcar, álcool combustível (etanol), aguardente e a produção de energia utilizando subprodutos da indústria. Nesse último aspecto da utilização da cana-de-açúcar, vem despertando interesses em pesquisas científicas, buscando a otimização na produção de uma matéria prima que possibilite um produto 
que além de possuir elevada riqueza em sacarose para a indústria, também possua médio a baixo teor de fibra, possibilitando assim a produção de energia renovável, a partir de sobra de bagaço após a industrialização da cana-de-açúcar (AGRIANUAL, 2009).

A safra 2012/13, chegou a 595,13 milhões de toneladas, com aumento de 6,2\% em relação à safra anterior (2011/12), que foi de 560,36 milhões de toneladas, indicando que a expansão da cultura continua em crescimento no Brasil (CONAB, 2013). Os levantamentos feitos para 2014 mostraram que a produção de cana-de-açúcar está estimada em 671,7 milhões de toneladas na safra 2014/15, representando um aumento de $2 \%$ em relação à produção do ano anterior (CONAB, 2014).

$\mathrm{Na}$ indústria, os dados atuais também mostram aumento contínuo no crescimento dos subprodutos (açúcar e etanol). A produção de açúcar para 2014/15 está estimada em 39,46 milhões de toneladas, $4,17 \%$ a mais que os 37,88 milhões de toneladas na safra passada, sendo que cerca de $71,48 \%$ do açúcar no país foi produzido na região Sudeste, 10,87\% na região Centro-Oeste, 8,90\% na região Nordeste, $8,64 \%$ na região Sul e $0,12 \%$ na região Norte. A produção de etanol para 2014/15 não tem aumento significativo, estimada em 28,37 bilhões de litros, representando um aumento 1,47\% em relação à safra anterior (27,96 bilhões de litros da safra 2013/14), que representa a produção 412,19 milhões de litros do combustível (CONAB, 2014).

A área agrícola ocupada com canaviais no Brasil (8,735 milhões de ha) apresentou um acréscimo de 3,6\% em relação à safra anterior, correspondendo a 318,7 mil hectares em relação à safra 2013/14. Esse aumento foi devido à expansão da área plantada no Centro-Sul do Brasil, correspondente a 4,5\% (345,5 mil hectares). No Norte-Nordeste do país, foi registrado um decréscimo de 2,5\% (26,9 mil hectares), contribuindo para a manutenção dados de produção para safra 2013/14. São Paulo, Mato Grosso do Sul, Goiás e Paraná foram os Estados com maior ganho de áreas, com 144,3 mil hectares, 57,9 mil hectares, 59,9 mil hectares e 58,3 mil hectares, respectivamente. Este crescimento ocorreu devido à expansão de novas áreas de plantio das novas usinas em funcionamento e a área da cana bisada, cana produzida na safra 2013/14 e que será colhida na safra 2014/15 (CONAB, 2014).

No entanto, na safra 2014/2015 está prevista uma diminuição na produtividade de 74,76 $\mathrm{Mg} \mathrm{ha}^{-1}$ para 73,57 $\mathrm{Mg} \mathrm{ha}^{-1}$, representando uma queda de 1,6\% na produtividade nacional nesta. Essa queda que se concentrou na Região Centro-Sul do Brasil, que provavelmente foi ocasionada por alterações climáticas, com ênfase na falta de chuvas no final de 2013, prejudicando a fase de rebrota da cana-de-açúcar na região, com diminuição de 77,84 $\mathrm{Mg} \mathrm{ha}^{-1}$ para 75,85 $\mathrm{Mg} \mathrm{ha}^{-1}(2,6 \%)$ registrada na Região Centro-Sul do país. No Norte-Nordeste do Brasil, foi registrado um crescimento no rendimento dos canaviais, com um aumento de $2,5 \%$ na área plantada, e de 3,7\% na 
produção, chegando a 6,3\% de aumento na produtividade (de 52,68 $\mathrm{Mg} \mathrm{ha}^{-1}$ para 55,99 $\mathrm{Mg} \mathrm{ha}^{-1}$ ), comparado a ultima safra de 2012/13 (CONAB, 2014).

O crescimento da produção no setor sucroalcooleiro no Brasil está caracterizado com maior significância, pelo crescimento da área plantada, quando comparada com a produtividade propriamente dita. O setor canavieiro continua a se expandir para a Região Centro-Oeste do Brasil, e essas tendências continuam sendo observadas nas safras atuais, com seqüência de crescimento na produção canavieira na região (CONAB, 2014).

\subsubsection{Morfologia da cana-de-açúcar}

A morfologia da cana-de-açúcar segue o padrão das demais plantas da família Poaceae. Apresenta parte aérea bem desenvolvida e de forma agrupada, formando touceiras, e caule do tipo colmo; possui folhas, inflorescências e frutos. A parte subterrânea é constituída de raízes e rizomas com nós e entrenós compactados(MOZAMBANI et al., 2006).

O caule, pertencente à parte aérea da planta, é o responsável pela sustentação das folhas e inflorescências (panículas), como também é nele que se concentra a maior parte dos vasos do câmbio vascular da cultura. É normalmente de porte ereto, tipo colmo, com a presença de nós e entrenós distintos e estes são bastante importantes na diferenciação de uma espécie para outra. Os internódios ou entrenós são de grande importância na identificação de diferentes variedades, isso porque apresentam formas variadas (cilíndricas, carretel, conoidal, obconoidal, tumescente ou barril). É neles que a planta acumula a sacarose, que é a matéria prima essencial da cultura. O nó, nódio ou região nodal, é a parte da cana onde se inserem as folhas e onde estão localizadas as gemas e a zona radicular da planta, formando o anel de crescimento (MOZAMBANI et al., 2006).

As folhas da cana-de-açúcar são ligadas ao colmo concrescidas nas regiões nodulares, em duas fileiras de forma oposta e alternada (MOZAMBANI et al., 2006). Apresenta folha do tipo lanceolada e composta por: lâmina foliar, bainha e colar, ligando-se ao colmo, de forma oposta e alternada. A coloração com a presença de manchas, situação ereta e rígida, ou flácida e arqueada, pilosidade, lâmina foliar serrilhada em formato alongado, e nas regiões intermediárias de ligação das folhas com o colmo, demonstram a presença de uma lígula membranosa, entre outras características da folha que podem variar de acordo com a variedade, o manejo ou ambiente de produção (CASAGRANDE, 1991; MOZAMBANI et al., 2006).

A inflorescência, do tipo bandeira, também conhecida como flecha, é uma panícula aberta, formada por uma raque de onde ramificam as espiguetas que, por sua vez, comportam as flores hermafroditas (CASAGRANDE, 1991; MOZAMBANI et al., 2006).

O sistema radicular da cana-de-açúcar é do tipo fasciculado, com raízes adventícias do rebolo (de fixação) e de perfilhos (COSTA et al., 2014); é bem desenvolvido, e seu desempenho 
varia com a textura do solo e condições hídricas e podem alcançar até $4 \mathrm{~m}$ de profundidade, com $85 \%$ nos primeiros $50 \mathrm{~cm}$ do solo, sendo que aproximadamente $60 \%$ do total ficam entre $20-30 \mathrm{~cm}$ de profundidade (CASAGRANDE, 1991; DILLEWIJN, 1952; MOZAMBANI et al., 2006). As primeiras raízes, ainda quando em cana-planta, são chamadas de raízes de fixação e são formadas a partir dos primórdios radiculares do rebolo plantado, das zonas radiculares são finas e muito ramificadas, e são apenas temporárias, e sua função é eventualmente assumida após os 2 a 3 meses pelas raízes do perfilho (DILLEWIJN, 1952; MILLER; GILBERT, 2014). Os mesmos autores explicaram ainda que a cana-de-açúcar utiliza como fontes nutricionais, as reservas do rebolo durante os primeiros 30 dias após o plantio. Isso acontece até que os perfilhos emitam suas próprias raízes (LUCCHESI, 2001).

Até que as raízes dos perfilhos surjam, são as raízes de fixação que garantem boa parte da absorção de água e sais minerais que garante a sua completa nutrição no período inicial de implantação do canavial. À medida que a touceira emite mais perfilhos, e esses emitem suas próprias raízes, o sistema radicular da mesma se apresenta com área de exploração cada vez maior, até que atinja uma situação de estabilidade, onde cada perfilho se comporta como uma planta individual com seu próprio sistema radicular, ocorrendo em seguida a renovações das raízes velhas (DILLEWIJN, 1952; LUCCHESI, 2001). É importante frisar que para um bom desenvolvimento radicular, não ocorra déficit hídrico na rizosfera da planta, haja vista que a renovação de raízes durante o ciclo da cultura depende de boas condições hídricas, e que essa mesma condição seja mantida, para evitar a morte das novas raízes, devido a um período seco (DILLEWIJN, 1952). O sistema radicular da cana-de-açúcar pode continuar ativo por um longo período de tempo depois do corte da planta, deixando de funcionar gradualmente, à medida que um sistema novo se forma, ao crescerem os perfilhos da soqueira (HUMBERT, 1974).

Cada variedade apresenta suas próprias características de eficiência fotossintética, dados biométricos (número de colmos, diâmetro de colmos, comprimento de colmos, comprimento e largura das folhas) e estas características são influenciados diretamente pelo clima, manejo e práticas culturais (CASAGRANDE, 1991). No entanto, a maneira como essas características morfológicas se expressam, varia bastante e são dependentes das condições ambientais, sistema de manejo da cultura e das variedades plantadas (PASSIOURA, 1997; INMAN-BAMBER; SMITH, 2005). Estudos sobre o comportamento das variedades de cana-de-açúcar, utilizando análises biométricas de crescimento, são importantes ferramentas para se investigar as diferenças estruturais e funcionais de cada variedade, assim como o potencial produtivo de cada uma, permitindo o uso para melhoramento genético de cultivares (PEREIRA; MACHADO, 1986; HERMANN; CÂMARA, 1999). 
É pelo uso da mensuração dos dados biométricos, que se pode observar possíveis reduções no comportamento do crescimento vegetal da cana-de-açúcar, em condições de deficiência hídrica no cultivo da cultura, podendo destacar o número de folhas e a área foliar (INMANBAMBER, 2004), a senescência foliar (SMIT; SINGEL, 2006), comprimento de colmos, diâmetro de colmos e o número de perfilhos (SILVA et al., 2012). A área foliar é reduzida (área de captação da luz solar), em conseqüência ocorre a diminuição da demanda de água pela cultura. A planta também pode reduzir o número de folhas emergentes, o que pode variar de acordo com o potencial genético de cada variedade (INMAN-BAMBER, 2004).

\subsubsection{Fenologia da cana-de-açúcar}

A cana-de-açúcar apresenta quatro estádios ou fases fenológicas distintas e podem ser classificados em: brotação e emergência, perfilhamento, crescimento dos colmos e maturação dos colmos, esquematizados na Figura 1 para cana de ano (GASCHO; SHIH, 1983).

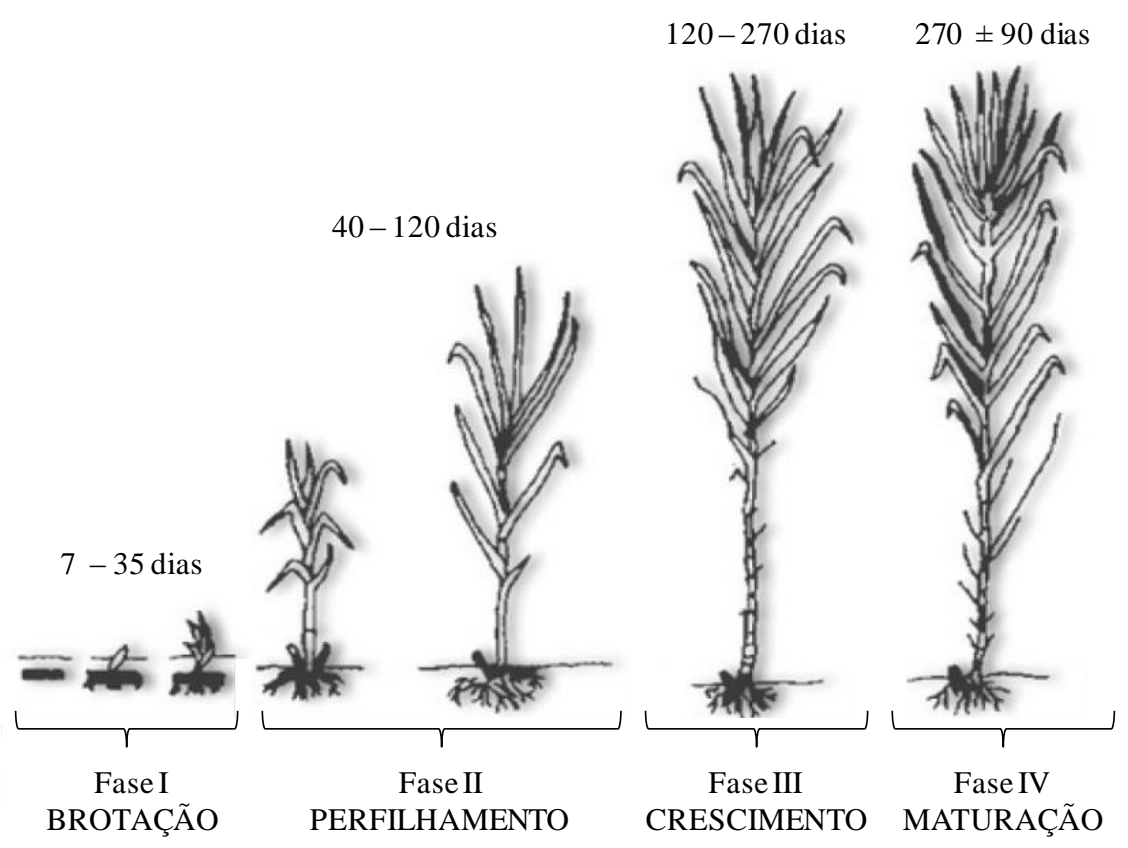

Figura 1. Resumo Fases fenológicas da cana-de-açúcar com ciclo anual (GASCHO; SHIH, 1983).

A brotação (I), ou também conhecida como emergência dos brotos primários, representa a estabilização, que se estende por aproximadamente 30 dias após a brotação (DAB). Esta fase é caracterizada quando o caule primário, ou broto, emergem na superfície do solo, e ocorre o enraizamento inicial do rebolo quando se trata de cana-planta. Esta primeira fase é muito dependente das condições ambientais fornecidas para a cultura, como também o manejo e época de plantio (GASCHO; SHIH, 1983). 
O perfilhamento (II) é considerado como a fase de estabelecimento da cultura, onde no processo ocorre o crescimento de mais de um colmo por planta, sendo estes denominados de perfilhos e são estimulados diretamente pela luz, umidade e temperaturas mais elevadas. Esse processo forma as chamadas touceiras, e inicia-se após a emergência, próximo aos 40 (dias após a brotação (DAB) e pode ir até os 120 DAB. É considerada uma fase de expressiva importância econômica para o canavial, pois vai determinar a quantidade de perfilhos por hectare, que juntamente com o início da acumulação de sacarose nos tecidos do colmo, determinarão a produtividade do cultivo (GASCHO; SHIH, 1983).

O crescimento dos colmos (III) inicia-se logo após o máximo perfilhamento, que vai aproximadamente dos 120 DAP, durando em média 270 dias, quando se intensifica o acúmulo de sacarose nos tecidos do colmo. Os colmos continuam crescendo em altura e iniciam o acúmulo de açúcar da base para a ponta. Essa fase também é caracterizada pelo intenso crescimento do sistema radicular da cultura, como também o amarelecimento e/ou secagem das folhas mais velhas da planta (GASCHO; SHIH, 1983; DIOLA; SANTOS, 2010).

A maturação da cana-de-açúcar (IV), é a última fase do ciclo, se inicia por volta dos 270 DAB e pode durar até 90 dias. Essa fase é caracterizada pela intensificação da concentração de sacarose nos colmos, que teve prévio início concomitante com a fase III, o que vai resultar diretamente na qualidade industrial da matéria-prima dos colmos remanescentes do perfilhamento na touceira (colmos industrializáveis). Nessa fase, quando as plantas atingem altura igual ou superior a dois metros, ocorre o amarelecimento e a secagem das folhas da porção mediana das plantas, o que indica que está sendo depositado açúcar nessa região (GASCHO; SHIH, 1983).

Quanto à maturação, Nunes Junior (1987) já classificava as variedades de cana-deaçúcar na região Centro-Sul onde ele relacionava o período da safra em que as plantas atingem o teor máximo de sacarose nos colmos. O autor classificou em quatro grupos distintos: maturação precoce; maturação semiprecoce; maturação média e maturação tardia. Outros autores definem o momento da colheita em função da variedade, manejo, época de plantio e duração do ciclo o que é caracterizado pelo nível de maturação do colmo, o que pode variar de 12 a 18 meses de acordo com a variedade (GASCHO; SHIH, 1983).

No Brasil, o plantio da cana-de-açúcar é feito normalmente em três épocas, o que resulta na cana-de-açúcar conhecida como cana-planta de ano (12 meses), cana-planta de ano e meio (18 meses), e a cana de inverno (adotado em propriedades em que há disponibilidade de irrigação, pois o plantio é realizado na época seca do ano) o que depende principalmente da variedade escolhida (MIRANDA, 2008). Após o primeiro corte, o ciclo é considerado anual e ela recebe a denominação de cana-soca ou de segunda folha; e, ressoca ou folha de enésima ordem, e assim por diante nos demais cortes até a última colheita, completando, assim, o ciclo da cana plantada, quando é feita a 
renovação do canavial. Normalmente, a lavoura de cana-de-açúcar permite de três a seis colheitas consecutivas, dependendo de vários fatores como: variedades, manejo de solo, e de água e o clima (GASCHO; SHIH, 1983; BOLONHEZI; PEREIRA, 1999).

\subsubsection{Variedades de cana-de-açúcar}

Cada genótipo tem suas características particulares, como: número de colmos por planta; dimensões do colmo; nós e entrenós; morfologia foliar; distribuição da parte aérea, como outras. No entanto, a maneira de que essas características morfológicas se expressam, é bem variada e dependente das condições ambientais e de manejo da cultura (MAULE et al., 2001; GASCHO; SHIH, 1983; BOLONHEZI; PEREIRA, 1999).

Mesmo estudos apontando que os caracteres morfológicos de cada variedade, favorecem a uma otimização do potencial fotossintético, o que diretamente interfere na qualidade da produção, como também na produtividade (RODRIGUES, 1995), a produção e até mesmo o ponto de maturação da cultura pode sofrer variações em função de vários fatores, sendo considerados como os mais críticos: temperatura, luz, disponibilidade de água e nutrientes, além do manejo da cultura e da variedade plantada (MAULE et al., 2001). Fato esse também estudado por Gascho e Shih (1983), e aceito por Bolonhezi e Pereira (1999), quando os mesmos afirmaram que o momento ideal para a colheita pode sofrer interferências em função da variedade plantada, duração do ciclo, manejo da maturação e condições climáticas.

Atualmente o Brasil possui quatro programas de melhoramento genético de cana-deaçúcar, que disponibilizam aos produtores do setor sucroalcooleiro as variedades para cultivo, acordo com as características desejadas para cada cultivo. Algumas das variedades produzidas no país por programas de melhoramento são: CV (Canavialis); CTC (Centro de Tecnologia Canavieira, sucessor da Copersucar - variedades SP); IAC (Instituto Agronômico de Campinas); e RB (Rede Interuniversitária para o Desenvolvimento do Setor Sucroalcooleiro - RIDESA).

A RIDESA é formada por dez Universidades Federais e é responsável pela obtenção de novas variedades de cana-de-açúcar, contribuindo para o avanço tecnológico e produtividade no setor sucroalcooleiro. Nesse sentido, a RIDESA trabalha em busca de variedades com diferentes características de manejo, adaptabilidade e ciclo (variedades precoces, médias e tardias), a fim de se obter variedades específicas para os ambientes agroecológicos do Brasil, e que as "variedades RB República do Brasil" liberadas pela RIDESA atinjam produtividades satisfatórias nos canaviais brasileiros, como também a obtenção de genótipos menos susceptíveis ao ataque de doenças graves, como ferrugem marrom e o carvão (DAROS et al., 2010).

Daros et al. (2010), descrevem as variedades RB pelas suas principais características agrícolas, morfológicas e de manejo. Algumas variedades RB descritas pelos autores são: 
a) A variedade RB867515 é uma das mais importantes da RIDESA, apresenta alta velocidade de crescimento, porte alto, hábito de crescimento ereto, alta densidade de colmo, diâmetro de colmo médio, alta uniformidade. Os colmos possuem entrenós cilíndricos, de cor verde arroxeado que se acentua quando expostos ao sol, pouca rachadura e leve ziguezague, pouca cera, e de fácil despalha. $\mathrm{O}$ anel de crescimento tem largura média, de cor verde-amarelada sob a palha e verde-arroxeado quando exposto ao sol. A zona radicular é de largura média, sem enraizamento aéreo. As gemas são de tamanho médio do tipo pentagonal, pouco proeminente ultrapassando o anel de crescimento e com poro germinativo apical. A almofada é de largura estreita e deprimida. As folhas são de largura média, arqueadas, curvas e bordos com serrilhamento pouco agressivo. A bainha é de comprimento longo com quantidade de cera regular e pouco joçal, neste caso, caduco. Apresenta duas aurículas, sendo uma lanceolada, de tamanho médio e outra curta de forma transitória. A lígula é de forma crescente. O dewlap é triangular. O palmito é médio, de cor verdearrocheado e com pouca cerra.

Nos ambientes de alto potencial de produção há possibilidades, devido à alta produtividade agrícola, de tombamento e atraso de maturação. É tolerante à seca e possui boa brotação de soqueira, mesmo quando colhida crua; possui alto teor de sacarose, crescimento rápido com alta produtividade. Pode ser cultivada em ambientes de média fertilidade natural, e apresenta excelente desempenho em solos de textura arenosa. Excelente desenvolvimento, com boa brotação na planta e socas. Pode ocorrer florescimento, neste caso, apresenta chochamento o qual não compromete a produção em função do crescimento expressivo. O teor de fibra é relativamente alto com média $13 \%$ nos ensaios colhidos.

b) A RB855156 É uma variedade que apresenta um palmito de tamanho regular, capitel fechado, com folhas de largura média, longas e arqueadas no terço superior, verde opacas, com bastante joçal na bainha que, no entanto, são decíduas e não muito agressivas; a bainha é de coloração verde, sem cerca e com borda estreita de cor marrom; possui aurícula em forma de lança, comprida e bem evidente (cor de palha); o dewlap também se destaca por ser de cor escura. Os colmos tem crescimento ereto, diâmetro médio a fino, com internódios dispostos em leve ziguezague, cilíndricos, de tamanho médio, de cor verde-clara, com tendência a apresentarem rachaduras, e pouca cera, que, porém, é evidente na região cerosa abaixo do nó; o anel de crescimento é de cor creme e pouco saliente. A gema é rombóide e arredondada, tamanho médio, sem almofada, e o seu topo não atinge o anel de crescimento; não ocorre a canaleta da gema.

Apresenta bom perfilhamento, especialmente nas socas; possui crescimento ereto e despalha fácil. Pode apresentar deficiência de germinação em algumas situações ainda não muito bem esclarecidas, razão porque se recomenda o seu plantio apenas em condições boas, tanto de idade de muda como de preparo de solo, umidade e temperatura. Garantindo bom estande a sua 
brotação de soqueira é bastante boa. Apresenta perfilhamento regular em cana-planta e muito boa em soca. Devido à sua propensão ao florescimento, recomenda-se a sua colheita sempre no início da safra, ainda mais porque, se deixada por mais tempo, pode apresentar intenso "declínio de outono". No aspecto fitossanitário não requer nenhum cuidado especial, pois é bastante resistente às principais doenças: carvão, escaldadura-das-folhas, estrias vermelhas, ferrugem marrom e mosaico.

c) A RB835486 apresenta touceiramento ralo, com colmos decumbentes na fase adulta, colmos medianamente empalhados, de fácil despalha, de diâmetro médio a grosso, e de cor verde arroxeada, com cera abundante; entrenós médios dispostos em leve ziguezague; gemas arredondadas, com pequena almofada e asas médias; capitel médio, folhas de largura e comprimento médios, eretas, geralmente dispostos em leque, com leve curvatura na ponta; uma aurícula deltóide e outra incipiente; bainha sem joçal. Apresenta produtividade alta, tanto em canaplanta como em cana-soca, com boa brotação e perfilhamento médio, com alto teor de sacarose, não sendo muito exigente em fertilidade de solo.

A ferrugem pode causar problemas na qualidade da produção em regiões de altitude elevada e áreas fertirrigadas, e neste último caso requer maior atenção ao manejo antecipado do corte. Por isso deve ser evitado corte tardio em regiões com condições ambientais que favoreçam o desenvolvimento da doença. Esta variedade possui ampla adaptabilidade e é recomendada para plantio em solos ácricos no Cerrado.

Câmara (1993) explicou que o sucesso na indústria canavieira deve se basear em três princípios básicos: produtividade, qualidade da matéria-prima e longevidade do canavial. A escolha da variedade correta a ser plantada é de fundamental importância para que se atinjam os três princípios supracitados, para que se obtenha produtividade com qualidade e baixo custo (SILVEIRA et al., 2002). Dias et al. (2012) que seria ideal que se plantasse uma ou mais variedades industriais melhoradas e com ciclos de maturação diferenciados, de forma que estas se adequassem às condições locais, considerando-se o clima, relevo, solo, além das características agroindustriais como: produtividade, teor de açúcares, rebrota, resistência à pragas e doenças, ausência de tombamento, entre outras, o que pode resultar em economia de até $98 \%$ e aumento de $15 \%$ na produção do canavial. O mesmo autor ainda afirmou que pode-se ter ganhos de produtividade de até $23 \%$ em $\mathrm{Mg} \mathrm{ha}^{-1}$, e até $77 \%$ no teor de sacarose do colmo colhido, o que resulta em rendimentos satisfatórios para o setor sucroalcooleiro.

As variedades de cana-de-açúcar apresentam respostas diferentes ao déficit hídrico, nesse sentido, os programas de melhoramento vegetal procuram divulgar as informações das variedades de cana-de-açúcar disponíveis no mercado, assim como as suas características com relação à tolerância à restrição hídrica e a resposta à irrigação, o que facilita o planejamento inicial do cultivo já que o produtor canavieiro poderá ter acesso a informações mais precisas sobre a 
característica de cada variedade e sua resposta às condições climáticas de sua região, tendo maior segurança de eficiência no sistema produtivo a ser implantado (IANMAN-BAMBER; SMITH, 2005; SILVA et al., 2008).

Com a expansão do setor canavieiro para a Região Centro-Oeste do Brasil, onde grande parte é dominada pelo Bioma Cerrado, faz com que as características climáticas sejam um fator determinante na escolha das variedades para o plantio, haja vista que o Cerrado brasileiro, possui características climáticas peculiares, com um período chuvoso e um seco bem definido (SANO et al., 2008), o que pode favorecer efeitos danosos ao cultivo da cana-de-açúcar, caso os períodos de maior necessidade hídrica da cultura não coincidam com a estação chuvosa do Bioma.

\subsection{Déficit hídrico nas culturas}

Períodos de estiagem e a falta de irrigação adequada podem favorecer a diminuição acentuada da água no perfil do solo, limitando o desenvolvimento dos vegetais não resistentes à restrição hídrica. Este é um fato que se repete em várias áreas agrícolas do mundo, onde se localizam em áreas de baixa pluviosidade anual, o que ocasionam efeitos danosos e respostas fisiológicas que afetam diretamente a produtividade agrícola (LECHINOSKI et al., 2007). Isso se justifica pelo fato de que, cerca de $90 \%$ da composição do peso fresco dos vegetais é composto pela água, que é responsável pela manutenção da turgescência e principal meio das reações dos ciclos metabólicos bioquímicos essenciais às plantas.

A restrição hídrica afeta diretamente a agricultura moderna, principalmente em regiões que possuem períodos de estiagem acentuados, trazendo prejuízos e limitações para a agricultura. Nesse sentido que as pesquisas avançam e buscam respostas com o objetivo de atenuar os danos causados, e estudando as características de culturas e variedades consideradas tolerantes a períodos consideráveis de restrição hídrica, o que pode definir planos para as estratégias de manejo em condições de seca (IANMAN-BAMBER; SMITH, 2005; OLIVEIRA et al., 2012).

Taiz e Zeiger (2013) definiram déficit hídrico como todo o conteúdo de água de um tecido ou célula situado abaixo do conteúdo de água mais alto exigido no estado de maior hidratação. Quando o déficit hídrico apresenta evolução suficientemente lenta para permitir mudanças nos processos de desenvolvimento, o estresse hídrico age em vários efeitos sobre o crescimento vegetal e pode até limitar a expansão foliar.

As plantas quando submetidas à situação de déficit hídrico, podem apresentar alterações morfológicas e fisiológicas que ajudam a prevenir e tolerar a perda de água, minimizando os efeitos deletérios causados pela falta de água. Essas modificações causadas pelo estresse hídrico desencadeiam mudanças estruturais e funcionais em todos os níveis, ocorrendo em moléculas como: proteínas e lipídios, agregação de moléculas nas membranas celulares, podendo até atingir 
organelas complexas como cloroplastos e mitocôndrias, evoluindo para a célula, tecidos e órgãos (LAWLOR, 2013).

Segundo Kiehl (1979) a situação de indisponibilidade de água faz com que as plantas possam apresentar mecanismos de adaptação aos diferentes ambientes, e passam a ter a capacidade de obter mais água como também aumentar a eficiência de uso da água disponível. Esse mecanismo de tolerância a períodos de intensa estiagem faz com que as plantas suportem o estresse hídrico por um maior intervalo de tempo, sendo esta considerada como uma "planta aclimatada", ou seja, que é quando a tolerância aumenta como conseqüência de exposição anterior; o que diverge de adaptação que é referente ao nível de tolerância determinado pela genética, sendo adquirido por um processo de seleção durante as gerações (TAIZ; ZEIGER, 2013). Lawlor (2013), se refere à tolerância à seca como sendo a capacidade da planta suportar a restrição hídrica sem danos ou decréscimo do seu potencial produtivo.

A tolerância à falta de água não pode ser por prolongada por tempo indeterminado, que as plantas ficam com suprimentos reduzidos pela ausência de água em quantidade satisfatória para as reações bioquímicas, e o uso continuado da água de suas reservas naturais (vacúolos e xilema). Uma das respostas das plantas ao estresse hídrico é a produção de ácido abscísico (ABA), um hormônio vegetal que é responsável pela regulação de vários aspectos ligados à fisiologia das plantas, tais como respostas ao estresse hídrico, inibição da germinação de sementes, crescimento do caule. Este fitormônio é sintetizado nas folhas maduras da planta, na extremidade da raiz e caule e é transportado para a região foliar que apresenta a maior transpiração e altera a regulação estomática da planta nessa região, fazendo com que os estômatos fechem com maior freqüência, evitando assim o excesso de perda de água pela transpiração como também reduz o crescimento por promover a dormência das gemas (MORENO, 2009). O último autor ainda explica que este fato ocorre no início do estresse hídrico fazendo com que a condutância estomática seja afetada, o que, como conseqüência, provoca a redução na disponibilidade de $\mathrm{CO}_{2}$ para a atividade fotossintética (TAIZ; ZEIGER, 2013).

A limitação no crescimento, como mencionado anteriormente, é considerada como a primeira resposta da planta ao déficit hídrico. Isso porque as atividades que dependem da turgidez celular ficam comprometidas, sendo as primeiras a expressarem resposta à falta de água na planta, pela redução da área foliar e crescimento radicular. Esse procedimento faz com que haja uma diminuição na área superficial de transpiração, conservando um suprimento mínimo de água no solo por um período maior (TAIZ; ZEIGER, 2013). Como uma adaptação físiológica, o aumento na síntese de $\mathrm{ABA}$, provoca maior queda de folhas senescentes, decorrentes da redução no suprimento de água para a planta. 
Outra alteração morfológica decorrente ao déficit hídrico é o aumento de cera na superfície foliar e/ou partes vegetativas da planta, que é uma resposta evolutiva de algumas espécies aos ambientes com limitações no suprimento de água. É uma cutícula espessa produzida pela planta que tem a função de reduzir a perda de água pela superfície foliar, não causando danos à eficiência fotossintética, pois as células epidérmicas não são fotossintéticas (TAIZ; ZEIGER, 2013).

Nas plantas sob estresse hídrico, a síntese de componentes protéicos é inibida e a degradação das proteínas é acelerada, provocando o acúmulo de aminoácidos e aminas livres. Logo, se caracteriza como distúrbio fisiológico no metabolismo das proteínas resultando na alteração das proteínas e aminoácidos, que favorece ao aumento da concentração de prolina. O acúmulo de prolina livre está relacionado a um mecanismo de sobrevivência das plantas durante períodos de estiagem, o que favorece a um melhor ajustamento osmótico induzido por esse aminoácido (LARCHER, 2000). Isso ocorre quando as plantas necessitam reduzir o potencial hídrico celular, com o objetivo de manter a turgidez das mesmas, e esse ajuste ocorre por meio de acúmulos de substâncias orgânicas conhecidas como osmorreguladores, como é o caso da prolina, carboidratos solúveis, $\mathrm{N}$ - $\alpha$-aminossolúveis e proteínas solúveis e enzimas antioxidantes (MARTINEZ; MORENO, 1992).

\subsection{Mecanismos de tolerância à restrição hídrica}

\subsubsection{Osmorreguladores}

O ajuste osmótico é caracterizado pelo aumento da concentração de solutos como açúcares, ácidos orgânicos, aminoácidos e íons orgânicos presentes no interior das células, que impedem que o volume celular seja alterado em decorrência de situações de estresses que causam a redução na quantidade de água na celular (TAIZ; ZEIGER, 2013). Esse mecanismo de regulação osmótica ou osmorregulação é a resposta da adaptação das plantas à situações de seca, onde o acúmulo de solutos a nível celular ocorrem em baixos potenciais hídricos, o que evita prejuízos nas funções protéicas, enzimas e membranas, onde acumulam moléculas hidrofílicas (alta afinidade por água) que protegem a célula contra a desidratação (INHAN-BAMBER; SMITH, 2005). Esta é uma estratégia adaptativa ao estresse, que é vital nos vegetais para suportar os efeitos causados por longos períodos de falta de água, sendo a prolina um dos principais solutos osmorreguladores quanto à estratégia de adaptação das plantas à estresses ambientais (ABDUL JALEEL et al., 2007).

A prolina é um aminoácido que se acumula no citoplasma celular quando a planta está em situação de estresse, mantendo as células vegetais com turgidez suficiente para as atividades vitais do metabolismo vegetal (BARTELS; SUNKAR, 2005). Além do ajustamento osmótico, a prolina também possui outras funções como: reserva de nitrogênio e carbono ( $\mathrm{N}$ e $\mathrm{C}$ ), estabilizador de proteínas e membranas, e a elimina radicais livres (RHEIN et al., 2011). 
A biossíntese da prolina, representado esquematicamente na Figura 2, pode ser realizada segundo duas vias metabólicas. A via direta (a), onde após a formação do glutamato semi-aldeído, a molécula se transforma em P5S ( $\Delta^{\prime}$-pirrolina-5-carboxilato) que é uma estrutura cíclica e percussora da prolina; a via indireta (b), ou também chamada de via dos derivados acetilados, dependente de ornitina, existe a presença dos grupos acetil ligados ao 2-amino impede essa reação interna, e uma estrutura aberta (a ornitina) é formada (RHEIN et al., 2011). As reações são catalisadas pelas enzimas P5C sintase (P5CS) e P5C redutase (P5CR), sendo que a primeira enzima é induzida em condições de estresse ambiental (hídrico, salino, ABA), o que não ocorre com a segunda enzima (SAMARAS et al., 1995). É um mecanismo presente em várias espécies vegetais, sendo eficaz na manutenção da turgidez celular e permitindo a manutenção do funcionamento estomático e da fotossíntese (TAIZ; ZEIGER, 2013).

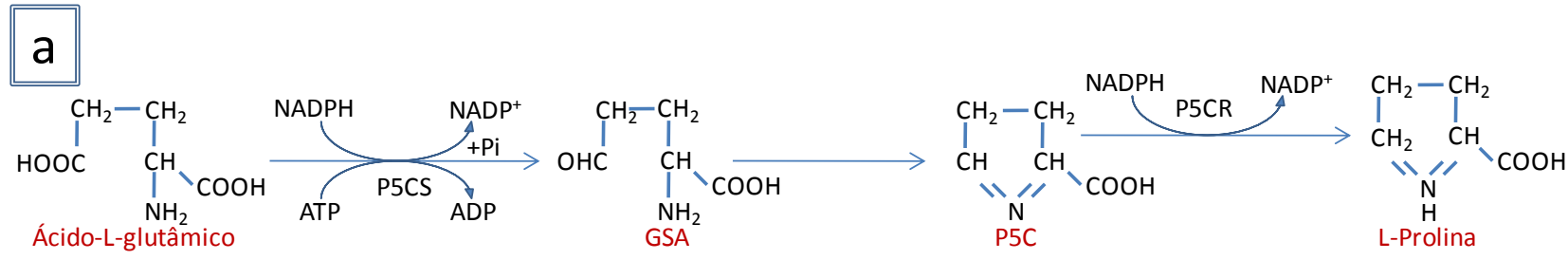

\section{b}
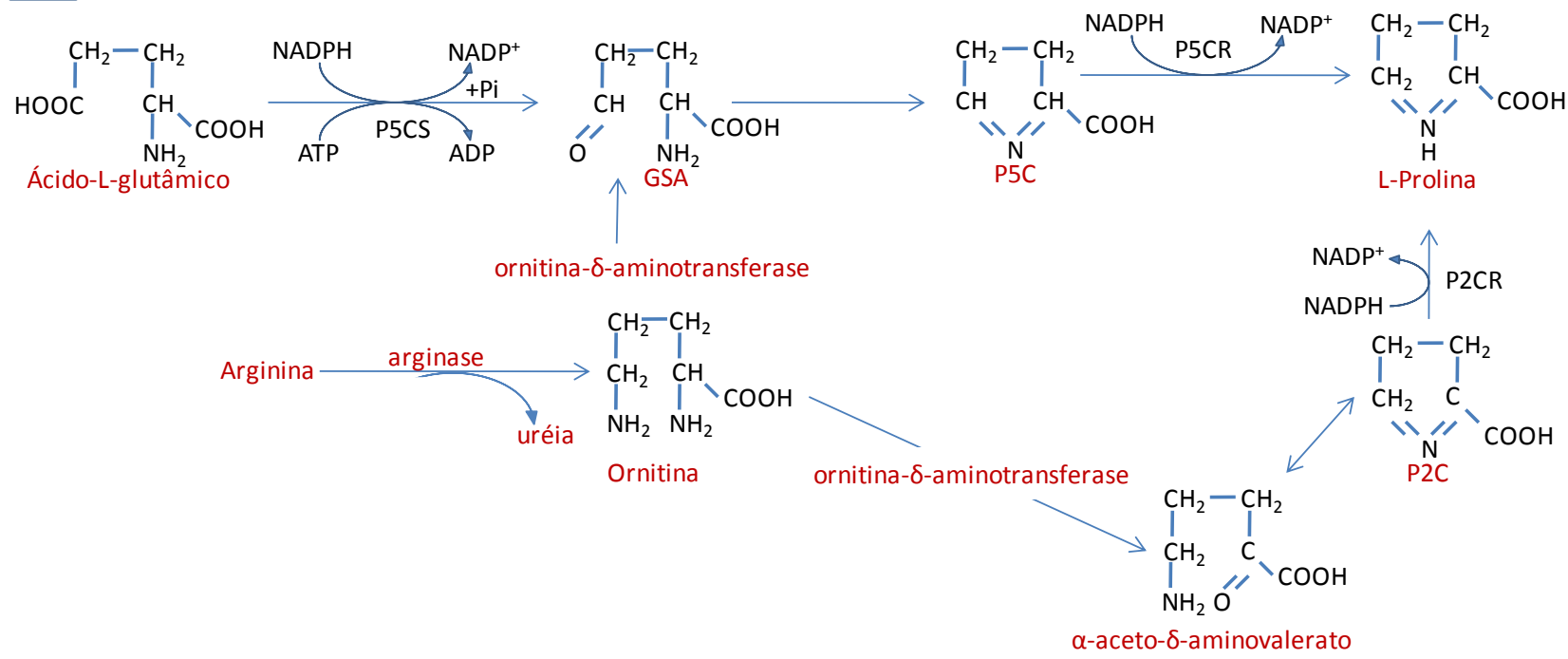

Figura 2. Via metabólica principal (A) e alternativa (B) de biossíntese de prolina em plantas (DELAUNEY; VERNA, 1993).

Outros solutos sintetizados pelas plantas também apresentam papel de importância no metabolismo vegetal durante estresses hídricos, como: o transporte de proteínas, canais transportadores de íons e aquaporinas que são proteínas da membrana que transportam água (TAIZ; ZEIGER, 2013). 


\subsubsection{Trocas gasosas}

As trocas gasosas ocorrem em maior parte na superfície foliar, como resultado da interação da planta com o ambiente. Esta interação é um dos meios para se estudar a resposta fisiológica da planta a estresses ambientais, e é utilizada por ser uma técnica rápida, precisa e aceitável, não sendo necessária a coleta de partes da planta (TORRES NETO et al., 2005).

A eficiência das trocas gasosas e a assimilação fotossintética estão diretamente relacionadas com as demais atividades metabólicas que contribuem para o aumento da produtividade (TAIZ; ZEIGER, 2013). No caso da transpiração, ela está relacionada ao potencial genético de cada planta, sendo considerado um mecanismo de adaptação para a manutenção das funções vitais na célula (MARTINS et al., 2010).

Estudos afirmaram que a transpiração na cana-de-açúcar é alterada conforme a disponibilidade hídrica no solo, no entanto, existem variedades que são consideradas tolerantes, como a RB98710, com também outras consideradas sensíveis, como a SP79-1011, RB72454 e a RB92579 (GONÇALVES et al., 2010). O efeito da restrição hídrica nas variedades de cana-deaçúcar pode ser verificado pelo auxílio da transpiração foliar, por apresentar redução intensa, principalmente em variedades sensíveis ao estresse hídrico, onde o fechamento dos estômatos é uma das primeiras reações nestas variedades de cana-de-açúcar (MACHADO et al., 2009; GONÇALVES et al., 2010; TRENTIN et al., 2011).

\subsubsection{Pigmentos fotossintetizantes}

A energia luminosa é inicialmente absorvida por pigmentos existentes em grandes quantidades nos tecidos vegetais. Podem ser de tipos e quantidades variadas, como: flavonóides, carotenóides, clorofilas, ficobilinas, entre outros; com distribuição que pode variar de acordo com a espécie vegetal (STREIT et al., 2005; TAIZ; ZEIGER, 2013).

As clorofilas (Figura 3) localizam-se nos cloroplastos, que são organelas responsáveis por duas reações importantes da fotossíntese, a fotoquímica (na membrana do tilacóide) e a bioquímica (no estroma do cloroplasto). Também são responsáveis por garantir energia na formação de ATP e NADPH na fotossíntese (TAIZ; ZEIGER, 2013). Possuem uma estrutura em forma de anel tipo porfirina com um átomo central de magnésio $(\mathrm{Mg})$, e com uma cauda de hidrocarbonetos hidrofóbicos, que é responsável pela fixação da molécula na membrana fotossintética (TAIZ; ZEIGER, 2013). 


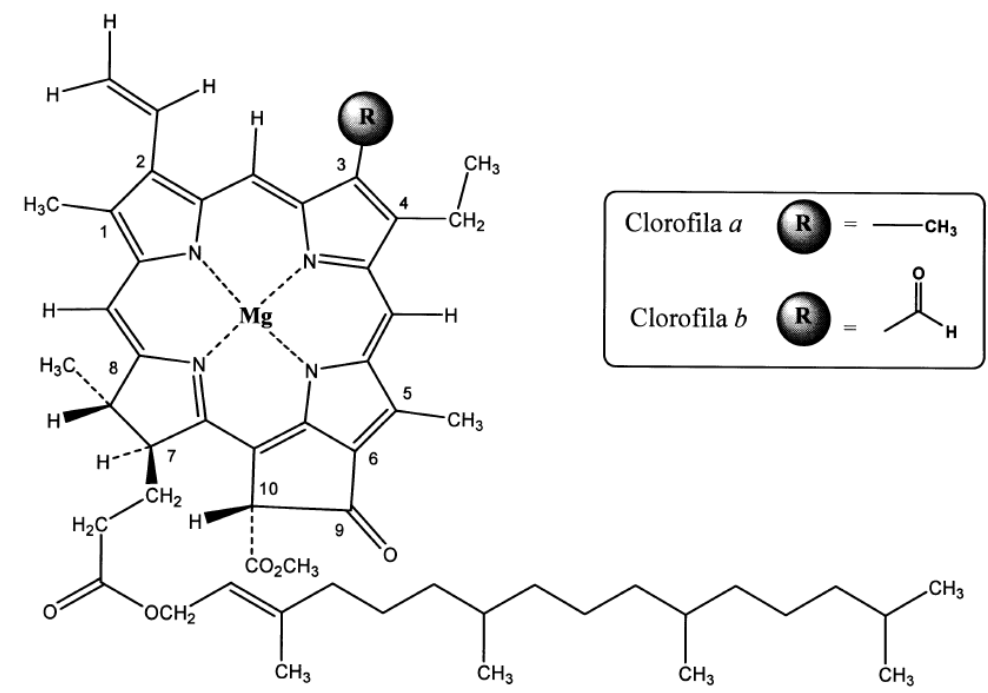

Figura 3. Estrutura química da clorofila $a$ e clorofila $b$ (STREIT et al., 2005).

Os pigmentos envolvidos no processo de fotossíntese são as clorofilas $a$ e os pigmentos acessórios: clorofila $b$, os carotenóides e as ficobilinas. As clorofilas $a$ e $b$ estão em proporção 3:1 na natureza, e elas se diferenciam em sua estrutura por um grupo metil (-CH3) presente no $\mathrm{C}-3$ no anel de porfirina da clorofila $a$, e um grupo aldeído (-CHO) na clorofila $b$, substituindo o metil (STREIT, 2005), como esquematizado na Figura 3.

O comportamento das clorofilas e outros pigmentos na cana-de-açúcar quando submetidas às condições de restrição hídrica, é parte importante no processo de seleção de variedades. Essas condições são responsáveis por alteração na pigmentação nas folhas das plantas, por alterar o processo enzimático e aumentar a produção de ABA e etileno que afetam a molécula de clorofila (SILVA et al., 2007). O estresse hídrico pode afetar a enzima clorofilase que é responsável pela degradação da clorofila, alterando a relação clorofila $a: b$, fato este que pode ser utilizado como ferramenta indicadora de situações de déficit hídrico (STREIT et al., 2005; TAIZ; ZEIGER, 2013), podendo facilitar no processo de seleção de genótipos de cana-de-açúcar (SILVA et al., 2007).

Golçalves et al. (2010) concluíram que a concentração de clorofila $a, b$, e $a+b$ reduziu conforme ocorreu a redução da disponibilidade de água no solo. Estas reduções podem ultrapassar os $40 \%$ nos valores das clorofilas, de acordo com a diminuição de água disponível no solo, o que confirma a eficácia do uso da clorofila como indicadora do estresse hídrico em estudos de melhoramento genético da cana-de-açúcar sob condição de restrição hídrica.

\subsection{Irrigação na cana-de-açúcar}

A irrigação é uma técnica agrícola que busca suprir as necessidades hídricas das culturas em regiões sujeitas a períodos prolongados de estiagem, sendo uma técnica que 
frequientemente vem sendo estudada e aprimorada nas regiões áridas e semi-áridas do mundo, pelo fato dessas regiões não terem precipitação regular e suficiente para suprir as necessidades das culturas, principalmente aquelas com ciclo de produção mais duradouro (SEGATO et al., 2006). Para isso, em algumas áreas se faz necessária a utilização de irrigação suplementar que garanta total ou parcialmente, o suprimento hídrico às culturas evitando perdas na eficiência produtiva ao longo dos períodos com pouca ou nenhuma precipitação pluviométrica, como é o caso do Cerrado brasileiro (MATIOLI et al., 1998; BEZERRA et al., 2013).

O uso da irrigação proporciona vários benefícios para a agricultura moderna, como: aumento de produtividade, maior eficiência no uso de insumos como na prática de adubação, calagem e gessagem; como também evita a falta de água em fases fenológicas críticas para a cultura, minimizando o risco de perdas econômicas (BERNARDO et al., 2006).

Dalri (2006) afirmou que para o cultivo da cana-de-açúcar existem quatro métodos básicos de sistemas de irrigação: superficial, por aspersão, localizado e de subsuperficie. No entanto, para a correta escolha, é necessário o estudo técnico prévio para se verificar a viabilidade técnica e econômica específica para cada área de produção.

A disponibilidade de água e a temperatura são fatores que afetam muito o crescimento das culturas cultivadas e essa necessidade varia de acordo com os diferentes estádios fenológicos da cultura (GAVA et al., 2011), ela também é influenciada pelas condições ambientais, manejo agrícola, período de plantio e variedade plantada. A produtividade, longevidade das soqueiras, produção de fitomassa, quantidade e qualidade da matéria-prima, são fatores que respondem diretamente à irrigação, pois tem relação direta com o consumo de água pela planta (MATIOLI et al., 1998).

A cana-de-açúcar, mesmo em condições de estresse hídrico, pode apresentar crescimento superior quando comparada a uma planta C3, mantendo o metabolismo e taxas fotossintéticas eficientes (CASAGRANDE; VASCONCELOS, 2008). Os mesmos autores ainda afirmaram que a cana-de-açúcar é uma cultura que responde bem à irrigação, sendo também muito eficiente no uso dela, necessitando de 69 a 168 litros de água para produzir um kg de fitomassa. Segundo Doorenbos e Kassam (1979) a cana-de-açúcar necessita para o bom rendimento no seu ciclo, de 1.500 a $2.500 \mathrm{~mm}$ de água, variando entre as fases fenológica; isso possibilita um manejo de irrigação e época de plantio mais eficiente, evitando-se perdas na produtividade por ocorrer estresse hídrico em fases fenológicas sensíveis, afetando na produção de biomassa e acumulação de sacarose (DANTAS NETO et al., 2006; MOURA et al., 2014), sendo essas características consideravelmente diferentes entre os diferentes genótipos (SILVA et al., 2008a). Por isso, para atingir eficiência satisfatória no sistema produtivo, assim como a sustentabilidade econômica da atividade sucroalcooleira, o uso de lâminas de irrigação adequadas à cada fase fenológica passa a 
ser o ponto crucial a fim de evitar o estresse hídrico na cultura nos períodos considerados críticos de seu crescimento e desenvolvimento, viabilizando o aumento da produtividade e, ao mesmo tempo potencializando o retorno econômico do setor e a longevidade do canavial (SILVA et al., 2008; GAVA et al., 2011; SILVA et al., 2012).

Com o recente desafio da exploração canavieira na Região Centro-Oeste do país, onde quase sua totalidade está em áreas de Cerrado, a disponibilidade hídrica deve ser cuidadosamente observada, exatamente pelo longo período de estiagem característico marcante do Bioma (SILVA et al., 2008). Por isso, para atingir eficiência satisfatória no sistema produtivo, assim como a sustentabilidade econômica da atividade sucroalcooleira, o uso de uma lâmina de irrigação adequada para cada fase fenológica passa a ser o ponto crucial a fim de evitar o estresse hídrico na cultura nos períodos considerados críticos de seu crescimento e desenvolvimento, viabilizando o aumento da produtividade e, ao mesmo tempo potencializando o retorno econômico do setor e a longevidade do canavial (SILVA et al., 2008a; GAVA et al., 2011; SILVA et al., 2012).

\subsubsection{Cana-de-açúcar cultivada sob déficit hídrico}

A cana-de-açucar é uma cultura que também pode ser afetada pela restrição hídrica, mesmo sendo uma planta tipo $\mathrm{C}_{4}$ e considerada bem adaptada às condições tropicais (CÂMARA; OLIVEIRA, 1993; WIEDENFELD, 2004; TEJERA et al., 2007). É uma cultura considerada sensível ao estresse hídrico, sendo que a falta de água em estádios fenológicos considerados críticos, pode ter impacto direto na produção do canavial (DOOREMBOS; KASSAM, 1979; MACHADO et al., 2009; GAVA et al., 2011). Alguns autores relatam que as fases iniciais da cultura (brotação e emergência) são o estádio fenológico considerado o mais crítico ao déficit hídrico (DOOREMBOS; KASSAM, 1979), no entanto, outros autores afirmam que é no perfilhamento e estabelecimento e crescimento da cultura são as fases mais sensíveis ao estresse hídrico por demandarem grande quantidade de água (IANMAN-BAMBER; SMITH, 2005; PIRES et al., 2008; MACHADO et al., 2009).

A cana-de-açúcar mantida sob estresse hídrico pode apresentar alterações morfológicas que afetam diretamente o rendimento do canavial e no geral, os efeitos dos mecanismos morfofisiológicos de adaptação ao estresse hídrico na cana-de-açúcar podem causar redução de até $25 \%$ no comprimento do colmo, e em média 35\% na fitomassa (IANMAN-BAMBER, 2005), quando comparado com as plantas irrigadas. No entanto, Gonçalves et al. (2010), ao estudar a resposta de diferentes variedades de cana-de-açúcar submetidas à deficiência hídrica durante a fase de maturação do colmo, verificou que o estresse hídrico provocou pouca interferência nos valores de clorofila-a e no crescimento em todas as variedades testadas (SP79-1011, RB72454, RB98710, RB92579). O mesmo autor ainda afirmou que as plantas apresentaram concentrações maiores no 
nível de prolina nas folhas sob estresse hídrico, porém os resultados de condutância estomática e taxa fotossintética não apresentaram alterações significativas.

Dias et al. (2012) explicaram que os indicadores das alterações fisiológicas seguem um padrão, podendo assim ser utilizados com o objetivo de identificar e verificar os efeitos do estresse hídrico sobre as plantas. $\mathrm{O}$ autor cita alguns desses indicadores: a) índice de clorofila: utilizando um SPAD (soil plant analysis development), que é um instrumento portátil que faz a medição do grau de pigmentação verde da planta, ou simplesmente o uso de um clorofilômetro; b) temperatura foliar: tem grande influência nas trocas gasosas das plantas, afetando diretamente a fotossíntese e a respiração; c) indicadores fitotécnicos: parâmetros biométricos para verificar o desenvolvimento (altura, diâmetro do caule, produção, etc); d) indicadores agroindustriais: ${ }^{\circ}$ Brix, Pol do caldo, fibras e outros atributos do caldo.

As avaliações biométricas (diâmetro e altura do colmo, densidade dos colmos, entre outros) podem ainda ser utilizadas na seleção de genótipos no melhoramento genético, também abastecem bancos de dados para modelagens, que permitem fazer estimativas de produtividade de culturas como a cana-de-açúcar (LANDELL; BRESSIANI, 2008). Essas alterações são expressões gênicas de tolerância e podem variar de acordo com a resposta da variedade de cana-de-açúcar utilizada (IANMAN-BAMBER; SMITH, 2005; RODRIGUES et al., 2009; TAIZ; ZEIGER, 2013), auxiliando no processo de caracterização e melhoramento vegetal das variedades cultivadas (PUGNAYRE et al., 1993, OLIVEIRA et al., 2010; GAVA et al., 2011), na capacidade produtiva das mesmas ou na coleta de dados para trabalhos de modelagem de crescimento da cultura em resposta aos diferentes ambientes e sistemas de produção em regiões onde ocorre a sazonalidade das chuvas e uma menor disponibilidade de água para utilização da irrigação (IANMAN-BAMBER; SMITH, 2005; OLIVEIRA et al., 2010).

Através da determinação dos dados biométricos, podem-se observar possíveis reduções no comportamento do crescimento vegetal da cana-de-açúcar sob deficiência hídrica. Logo, a área foliar é reduzida (área de captação da luz solar), em conseqüência reduz a demanda de água pela cultura. A planta também pode reduzir o número de folhas emergentes, o que pode variar de acordo com o potencial genético de cada variedade. A diminuição na abertura e crescimento das folhas é afetada pela baixa absorção de água, provocando acúmulo de folhas no cartucho e estas retornam ao seu crescimento normal após o suprimento de água ser adequado ao exigido pela planta (INMANBAMBER, 2004).

Pugnaire et al. (1994) explicaram que a reconhecida eficiência fotossintética das plantas tem expressiva redução no estado de deficiência hídrica, desencadeando uma seqüência de efeitos fisiológicos e morfológicos. O autor observa que já no início da diminuição da quantidade ideal de 
água no sistema produtivo, provoca alterações nos processos fisiológicos da planta (Tabela 1), o que faz a planta responder com os mecanismos de adaptação para tolerar a situação de estresse.

Tabela 1. Sensibilidade relativa ao estresse hídrico com relação a vários processos fisiológicos da planta. As barras sólidas horizontais indicam a gama de níveis de estresse dentro dos quais processos fisiológicos da planta são primeiramente afetados As barras fragmentadas indicam a porção da faixa do potencial hídrico em que a resposta fisiológica não está bem estabelecida (PUGNAIRE et al., 1994).

Processos afetados
(-) decréscimo
(+) acréscimo
Expansão celular (-)
Síntese da parede celular $(-)^{\mathrm{a}}$
Síntese de proteína $(-)^{\mathrm{a}}$
Formação de Protoclorofila $(-)^{\mathrm{b}}$
Nível de nitrato redutase $(-)$
Síntese de ABA (-)
Abertura dos estômatos $(-)$
Assimilação de CO ${ }_{2}(-)$
Respiração (+)
Condutância no xilema $(-)^{\mathrm{c}}$
Acumulação de prolina $(+)$
Nível de açúcar $(+)$
[Rápido crescimento dos tecidos; ${ }^{\mathrm{b}}$ Folhas estioladas; ${ }^{\mathrm{c}}$ Deve depender das dimensões do xilema

Pugnaire et al. (1994) citaram outros mecanismos fisiológicos de adaptação das plantas em resposta e intensidade do estresse hídrico, como a diminuição: expansão celular, síntese da parede celular, síntese de proteína, formação de protoclorofila, nível de nitrato redutase, síntese de $\mathrm{ABA}$, abertura dos estômatos, assimilação de $\mathrm{CO}_{2}$ para a fotossíntese (o que eleva a resistência difusiva ao vapor de água, o que reduz a transpiração, afeta também o fluxo de nutrientes e metabólitos na planta (WU; CAMPBELL, 2007), condutância no xilema; e o aumento do(a): respiração, acumulação de prolina, nível de açúcar (Tabela 1).

Dentre os mecanismos morfológicos de tolerância à seca das plantas, destacam-se: o enrolamento das folhas, senescência foliar, sistema radicular profundo, redução de área foliar, aumento da espessura foliar, folhas com a presença de tricomas, sendo que a intensidade de expressão desses mecanismos varia entre as variedades comerciais disponíveis para plantio (PUGNAIRE et al., 1994; IANMAN-BAMBER; SMITH, 2005). Essas informações são importantes quando se trata de um sistema produtivo em regiões de clima Tropical Estacional, que apresentam períodos bem definidos de chuva e seca (SILVA et al., 2001), gerando uma menor disponibilidade de água para utilização da irrigação nos períodos de estiagem, como é o caso do Cerrado brasileiro. 


\subsection{Referências Bibliográficas}

ABDUL JALEEL, C.; MANIVANNAN, P.; KISHOREKUMAR, A.; SANKAR, B.; GOPI, R.; SOMASUNDARAM, R.; PANNEERSELVAM, R. Alterations in osmoregulations, antioxidant enzymes and indole alkaloid levels in Catharanthus roseus exposed to water deficit. Colloids and Surfaces B: Biointerfaces, v.59, p.150-157, 2007.

AGRIANUAL 2009: Anuário estatístico da agricultura brasileira. São Paulo: FNP Consultoria \& Comércio, 2009. 495p.

BARTELS, D.; SUNKAR, R. Drought and salt tolerance in plants. Critical Reviews in Plant Sciences, v.24, p.23-58, 2005.

BASTOS, E. Cana-de-açúcar, o verde mar de energia. São Paulo: Ícone, 1987. 130p.

BERNARDO, S.; SOARES, A. A.; MANTOVANI, E. C. (Eds.). Manual de irrigação. 8.ed. Viçosa: UFV, 2006, 623p.

BEZERRA, A. R. G.; VIANA, S. B. A. SILVA, M. A. V.; MOSCON, E. S.; PINHEIRO, A. C. T. Avaliação do manejo da irrigação na cultura do algodão. Revista Sodebras, Lorena, v.8, n.85, p.4043, 2013.

BOLONHEZI, D.; PEREIRA, J. C. V. N. A. Plantio direto na Alta Mogiana. O Agronômico, Campinas, v. 51, p. 12-15, 1999.

BRASIL. Ministério do Meio Ambiente. Disponível em: <http:// http://www.mma.gov.br/biomas/cerrado >. Brasília. Acesso em: 02 jul. 2014.

CÂMARA, G. M. S.; OLIVEIRA E. A. M. Produção de cana-de-açúcar. ESALQ /USP / Departamento de Agricultura, Piracicaba: FEALQ. 1993. 242p.

CÂMARA, G.M.S. Ecofisiologia da cultura da cana-de-açúcar. In: CÂMARA, G.M.S. Produção de cana de açúcar. Piracicaba: ESALQ, 1993. p.31-64.

CASAGRANDE, A. A. Tópicos de morfologia e fisiologia da cana-de-açúcar. Jaboticabal: FUNEP, 1991, 157p.

CASAGRANDE, A. A.; VASCONCELOS, A. C. M. Fisiologia da parte aérea. In: DINARDO MIRANDA, L. L.; VASCONCELOS, A. C. M.; LANDELL, M. G. A. (Eds.). Cana-de-açúcar. Campinas: Instituto Agronômico, 2008. p.57-78.

CHAVEIRO, E. O cerrado em disputa: sentidos culturais e práticas sociais contemporâneas. In: ALMEIDA, M.G. et al. (Orgs.) Geografia e cultura: os lugares da vida e a vida dos lugares. Goiânia: Vieira, 2008. p. 75- 97.

CHAVES, J. B. P.; SILVA, C. A. B.; SILVA, F. C.; CESAR, M. A. A. Produção, qualidade e mercado de açúcar mascavo, melado e rapadura, no Brasil. In: SILVA, F. C. DA; CESAR, M. A.A.; SILVA, C. A. B. (Eds.). Pequenas indústrias rurais de cana-de-açúcar: melado, rapadura e açúcar mascavo. Brasília: Embrapa Informação Tecnológica, 2003, p. 11-20. 
CONAB, Companhia Nacional de Abastecimento. Acompanhamento de safra brasileira: canade-açúcar. Segundo levantamento, agosto/2012. Brasília: Conab, 2012. 18 p.

CONAB, Companhia Nacional de Abastecimento. Acompanhamento de safra brasileira: canade-açúcar, v.1-Safra 201/2015, n.1- Primeiro levantamento, abril/2014. Brasília: Conab, 2014. 20 p.

COSTA, M. C. G.; MAZZA, J. A.; VITTI, G. C. Variedades de cana-de-açúcar vs. adaptação aos solos vs. renovação do sistema radicular. Disponível em: < http://www.ipni.net/ppiweb/pbrazil.nsf/b2aaf15da221a95785256a6d006d7a23/4c603bf804ee5a380 32570d8004c0634/\$FILE/Anais\%20Mirian\%20Cristina\%20Gomes\%20Costa.pdf>. Acesso em: 06 jul. 2014.

CRONQUIST, A. An integrated system of classification of flowering plants. New York: Columbia University Press, 1981. 1262p.

DALRI, A. B. Irrigação em cana-de-açúcar. In: SEGATO, S. V.; PINTO. A. S.; JENDIROBA, E.; NÓBREGA, J. C. M. (Eds.). Atualização da produção de cana-de-açúcar, Piracicaba: CP2, 2006, p.157-170.

DANTAS NETO, P.; FIGUEREDO, J. L. C.; FARIAS, C. H. A.; AZEVEDO, H. M.; AZEVEDO, C. A. V. Resposta da cana-de-açúcar, primeira soca, a níveis de irrigação e adubação de cobertura. Revista Brasileira de Engenharia Agrícola e Ambiental, v.10, n.2, p.283-288, 2006.

DAROS, E.; OLIVEIRA, R. A.; ZAMBON, J. L. C.; FILHO, J. C. B. Catálogo nacional de variedades "RB" de cana-de-açúcar. Curitiba: RIDESA, 2010. 136 p.

DELAUNEY, A. J.; VERNA, D. P. Proline biosynthesis and osmoregulation in plants. The Plant Journal, Reslington, v.4, n.2, p.215-223, 1993.

DIAS, C. M. O.; CORSATO, C. E.; SANTOS, V. M.; SANTOS, A. F. S. Indicadores fitotécnicos, de produção e agroindustriais em cana de açúcar cultivada sob dois regimes hídricos. Revista Caatinga, Mossoró, v. 25, n. 3, p. 58-65, 2012.

DILLEWIJN, C.V. Botany of sugarcane. Waltham: Chronica Botanica, 1952. 371 p.

DIOLA, V.; SANTOS, F. Fisiologia. In: SANTOS, F.; BORÉM, A.; CALDAS, C. (E.d.) Cana de açúcar: Bioenergia, açúcar e álcool; Tecnologias e perspectivas. Viçosa: UFV, 2010. 577p.

DOORENBOS, J; KASSAM, A. H. Yield response to water. Rome: FAO, 1979. 197 p. (Irrigation and Drainage Paper, 33)

FERNANDES, A.J. Manual da cana-de-açúcar. 2. ed. São Paulo: Livroceres, 1990. 196p.

GASCHO, G. J.; SHIH, S. F. Sugarcane. In: TEERE, I.D., PEET, M.M. (Eds.). Crop-water relations. New York: A Wirley Interscience, 1983, p. 445-479.

GAVA, G. J. C.; SILVA,M. A.; SILVA, R. C.; JERONIMO, E. M.; CRUZ, J. C. S.; KÖLLN, O. T. Produtividade de três cultivares de cana-de-açúcar sob manejos de sequeiro e irrigado por gotejamento. Revista Brasileira de Engenharia Agrícola Ambiental. Campina Grande, v. 15, n. 3, p. 250-255, 2011. 
GOEDERT, W. J. Uso e manejo dos recursos naturais do Cerrado: solo e clima. In: SIMPÓSIO SOBRE O CERRADO, 5., 1979, Brasília. Cerrado: uso e manejo. Brasília: Editerra, 1980. p.475498.

GONÇALVES, E. R.; FERREIRA, V. M.; SILVA, J. V.; ENDRES, L.; BARBOSA, T. P.; DUARTE, W. G. Trocas gasosas e fluorescência da clorofila a em variedades de cana de açúcar submetidas à deficiência hídrica. Revista Brasileira de Engenharia Agrícola e Ambiental, Campina Grande, v.14, n.4, p.378-386, 2010.

HUMBERT, R. P. El cultivo de la caña de azucar. México: Companhia Editorial Continental, 1974. 719p.

IANMAN-BAMBER, N. G; SMITH, D. M. Water relations in sugarcane and response to water deficits. Field Crops Research, Amsterdam v.92, p.185-202, 2005.

IBGE. Estatística da produção agrícola. Brasília: IBGE, 2012. Disponível em: <www.ibge.gov.br>. Acesso em: 15 nov. 2014.

IBRAM. Instituto Brasília Ambiental. Disponível em: <http://www.ibram.df.gov.br/informacoes/meio-ambiente/bioma-cerrado.html >. Brasília, 8 nov. 2012. Acesso em: 02 jul. 2014.

INMAN-BAMBER, N. G. Sugarcane water stress criteria for irrigation and drying off. Field Crops Research, Amsterdam, v.89, n.1, p.107-122, 2005.

KIEHL, E.J. Manual de edafologia. São Paulo: Ceres, 1979. 264p.

KLUTHCOUSKI, J.; STONE, L. F.; ADAIR, H. Integração lavoura-pecuária. Santo Antônio de Goiás: Embrapa Arroz e Feijão, 2003. 570 p.

LANDELL, M. G. A.; BRESSIANI, J. A. Melhoramento genético, caracterização e manejo varietal. In: DINARDO-MIRANDA, L. L.; VASCONCELLOS, A. C. M.; LANDELL, M. G. A. (Eds.). Cana-de-açúcar. Campinas: IAC, 2008 , p.101-155

LAWLOR, D.W. Genetic engineering to improve plant performance under drought: physiological evaluation of achievements, limitations, and possibilities. Journal of Experimental Botany, Oxford, v. 64, n. 1, p. 83-108, 2013.

LOPES, A. S. Solos sob "cerrado": características, propriedades e manejo. Piracicaba: PATAFOS, 1983. $162 \mathrm{p}$.

LUCCHESI, A. A. Cana-de-açúcar (Saccharum spp.). In: CASTRO, P. R. C.; KLUGE, R. A. (Eds.). Ecofisiologia de culturas extrativas: cana-de-açúcar; seringueira; coqueiro; dendezeiro e oliveira. Cosmópolis: Stoller do Brasil, 2001. p.13-45.

LUCHIARI JÚNIOR, A.; RESENDE, M.; RITCHEY, K. D.; FREITAS JUNIOR, E. de; SOUZA, P. I. M. de. Manejo do solo e aproveitamento de água. In: GOEDERT, W. J. (Ed.). Solos dos cerrados: tecnologias de estratégias de manejo. Planaltina: Embrapa-CPAC, 1987. p. 285-322.

MACÊDO, G. A. R.; COSTA, E. L., VIANA, M. C. M., FERREIRA, J. J.; PIRES, J. F.; FREIRE, F. M. Características agronômicas e químicas das variedades de cana-de-açúcar RB83-5486 e 
RB86-7515 sob irrigação e sequeiro. Revista Brasileira de Engenharia Agrícola e Ambiental, Campina Grande, v.16, n.6, p. 599-603, 2012.

MACHADO, R. S.; RIBEIRO, R. V. MARCHIORI, P. E. R.; MACHADO, D. F. S. P.; MACHADO, E. C.; LANDELL, M. G. A. Respostas biométricas e fisiológicas ao déficit hídrico em cana-de-açúcar em diferentes fases fenológicas. Pesquisa Agropecuária Brasileira, Brasília, v.44, n.12, p.1575-1582, 2009.

MARTINEZ, C. A.; MORENO, U. Expresiones fisiologicas de resistencia a la sequia en dos variedades de papa sometidas a estres hidrico. Revista Brasileira de Fisiologia Vegetal, Brasília, v.4, v.1, p. 33-38, 1992.

MARTINS, J. D.; CARLESSO, R.; KNIES, A. E.; OLIVEIRA, Z. B.; BROETTO, T.; RODRIGUES, G. J. Potencial hídrico foliar em milho submetido ao déficit hídrico. Irriga, Botucatu, v. 15, n.3, p. 324-334, 2010.

MATIOLI, C.S.; FRIZZONE, J.A.; PERES, F.C. Irrigação suplementar da cana-de-açúcar: modelo de análise de decisão para a região norte do Estado de São Paulo. Stab - Açúcar, Álcool e Subprodutos, Piracicaba, v.17, n.2, p.42-5, 1998.

MATOS, P. F.; PESSÔA, V. L. S. A apropriação do cerrado pelo agronegócio e os novos usos do território. Revista de Geografia Agrária, Uberlândia, v. 9, n. 17, p. 6-26, 2014.

MAULE, R. F.; MAZZA, J. A.; MARTHA JR., G. B. Produtividade agrícola de cultivares de canade-açúcar em diferentes solos e épocas de colheita. Scientia Agricola, Piracicaba, v. 58, n. 2, p.295-301, 2001.

MENEGUEllo, L. A.; CASTRO, M. C. A. A. O Protocolo de Kyoto e a geração de energia elétrica pela biomassa da cana-de-açúcar como mecanismo de desenvolvimento limpo. Revista Internacional de Desenvolvimento Local, Campo Grande, v. 8, n. 1, p. 33- 43, 2007.

MIELNICZUK, J. Matéria orgânica e sustentabilidade de sistemas agrícolas. In: SANTOS, G. A.; SILVA, L. S.; CANELLAS, L. P.; CAMARGO, F. A. O. Fundamentos da matéria orgânica do solo: ecossistemas tropicais e subtropicais. 2 ed. Porto Alegre: Metrópole, 2008. p.1-18.

MILlER, J. D.; GILBERT, R. A. Sugarcane botany: a brief view. Disponível em:<http://edis.ifas.ufl.edu/sc034>. Acesso em: 06 jul. 2014.

MIRANDA, J. R. História da cana-de-açúcar. Campinas: Komedi, 2008. 167p.

MORAES, M. A. F. D. Indicadores do mercado de trabalho do sistema agroindustrial da cana-deaçúcar do Brasil no período 1992-2005. Estudos Econômicos, São Paulo, v. 37, n. 4, p. 605-619, 2007.

MOREIRA, H. M.; GIOMETTI, A. B. R. Protocolo de Quioto e as possibilidades de inserção do Brasil no Mecanismo de Desenvolvimento Limpo por meio de projetos em energia limpa. Contexto Internacional, Rio de Janeiro, v. 30, n. 1, p. 9 - 47, 2008.

MORENO, L. P. F. Respuesta de las plantas al estrés por déficit hídrico. Una revisión. Agronomía Colombiana, Bogotá, v. 27, n. 2, p. 179-191, 2009. 
MOURA, L. C.; SILVA, N. F.; CUNHA, F. N.; BASTOS, F. J. C.; CÉLIA, J. A.; TEIXEIRA, M. B. Índice de maturação da cana-de-açúcar fertirrigada sobre diferentes lâminas. Revista Brasileira de Agricultura Irrigada, v.8, n.1, p.64-76, 2014.

MOZAMBANI, A. E; PINTO, A. S.; SEGATO, S. V.; MATTIUZ, C. F. M. História e morfologia da cana-de-açúcar. In: SEGATO, S. V.; PINTO, A. S.; JENDIROBA, E.; NÓBREGA, J. C. M. Atualização em produção de cana-de-açúcar. Piracicaba: CP 2, 2006. p.11-18.

NUNES JUNIOR, D. M. S. Variedades de cana-de-açúcar. In: Paranhos, S. B. Cana-de-açúcar: cultivo e utilização. São Paulo: Fundação Cargill, 856p. cap. 2 v.1, p.187-259, 1987.

OLIVEIRA, E. C. A.; OLIVEIRA, R. I.; ANDRADE, B. M. T.; FREIRE, F. J.; JÚNIOR, M. A. L.; MACHADO P. R . Crescimento e acúmulo de matéria seca em variedades de cana-de-açúcar cultivadas sob irrigação plena. Revista Brasileira de Engenharia Agrícola Ambiental. Campina Grande, v. 14, n. 9, p. 951-960, 2010.

OLIVEIRA, R. C.; ROSA, M.; COSTA, A. C.; TEIXEIRA, M. B.; SOARES, F. A. L.; GAVA, G. J. C. Efeitos da restrição hídrica e de nitrogênio no crescimento e na fisiologia da cana-de-açúcar. In: Workshop Internacional de Inovações Tecnológicas na Irrigação, IV Winotec, 2012, Fortaleza. Proceedings..., protocolo 138.

PASSIOURA, J. B. Drought and drought tolerance. In: BELHASSEN, E. (Ed.). Drought tolerance in higher plants: genetical, physiological and molecular biological analysis. Dordrecht: Kluwer, 1997. p.1-5.

PEREIRA, A. R.; MACHADO, E. C. Um simulador dinâmico do crescimento de uma cultura de cana-de-açúcar. Bragantia,v.45, n.1, p.107-122, 1986.

PIRES, R. C. M.; ARRUDA, F. B.; SAKAI, E. Irrigação e drenagem. In: DINARDO-MIRANDA, L. L.; VASCONCELOS, A. C. M.; LANDELL, M. G. A. (Eds.). Cana-de-açúcar. Campinas: Instituto Agronômico, 2008. p.631-670.

PUGNAIRE, F. I.; ENDOLZ, L. S.; PARDOS, J. Constraints by water stress on plant growth. In: PESSARAKLI, M. Handbook of plant and crop Stress. New York: Dekker, 1994. p. 247-259.

RAMOS, P. A indústria canavieira do Brasil: referencial historiográfico, temas e fontes. América Latina En La História Econômica, Cidade do México. v. 1, p.1, 1999.

RESENDE A. S.; SANTOS A. O.; GONDIM A. O.; XAVIER R. P.; COELHO C. H. M.; OLIVEIRA, O. C.; ALVES B. J. R.; BODDEY R. M.; URQUIAGA S. Efeito estufa e o seqüestro de carbono em sistemas de cultivo com espécies florestais e na cultura de cana-de-açúcar. Seropédica: Embrapa Agrobiologia, 2001. 23p. (Embrapa-CNPAB. Documentos, 134).

RHEIN, A. F. L.; SANTOS, D. M. M.; CARLIN, S. D. Atividade da enzima redutase do nitrato e teores de prolina em raízes de cana-de-açúcar sob os estresses hídrico e ácido no solo. Semina, Londrina, v.32, n.4, p.1345-1360, 2011.

RODRIGUES, F. A.; LAIA, M. L.; ZINGARETTI, S. M. Analysis of gene expression profiles under water stress in tolerant and sensitive sugarcane plants. Plant Science, Ireland, v. 176, p. 286302, 2009. 
RODRIGUES, J.D. Fisiologia da cana-de-açúcar. Botucatu: Universidade Estadual Paulista UNESP, 1995. 69 p.

SANO. S. M.; ALMEIDA, S. P.; RIBEIRO, J. F. Cerrado: ecologia e flora. Brasília: Embrapa Informação Tecnológica, 2008. 1279 p. 2v.

SEGATO, S. V.; PINTO. A. S.; JENDIROBA, E.; NÓBREGA, J. C. M. Atualização da produção de Cana-de-açúcar. Piracicaba: CP2: 2006, 415p.

SILVA, D. B.; SILVA, J. A.; JUNQUEIRA, N. T. V.; ANDRADE, L. R. M. Frutas do cerrado. Brasília: Embrapa Informações Tecnológica, 2001. 179p.

SILVA, M. A.; JIFON, J. L.; SILVA, J. A. G.; SHARMA, V. Use of physiological parameters as fast tools to screen for drought tolerance in sugarcane. Brazilian Journal of Plant Physiology, Londrina, v.19, n.3, p.193-201, 2007.

SILVA, M. A.; SILVA, J. A. G.; ENCISO, J.; SHARMA, V.; JIFON, J. Yield components as indicators of drought tolerance of sugarcane. Scientia Agricola, Piracicaba, v.65, n.6, p.620-627, 2008.

SILVA, M. A.; SOARES, R. A. B.; LANDELL, M. G. A.; CAMPANA, M. P. Agronomic performance of sugarcane families in response to water stress. Bragantia, Campinas, v.67, n.3, p. 655-661, 2008.

SILVA, T. G. F.; MOURA, M. S. B.; ZOLNIER, S.; SOARES, J. M.; VIEIRA, V. J. S.; GOMES JÚNIOR, W. F. Requerimento hídrico e coeficiente de cultura da cana-de-açúcar irrigada no semiárido brasileiro. Revista Brasileira de Engenharia Agrícola Ambiental, Campina Grande, v. 16, n. 1, p. 64-71, 2012.

SILVEIRA, L. C. I.; BARBOSA, M. H. P.; OLIVEIRA, M. W. Manejo de variedades de cana-deaçúcar predominantes nas principais regiões produtoras de cachaça de Minas Gerais. Informe Agropecuário, Belo Horizonte, v. 23, n.217, p.25-32, 2002.

SMIT, M. A.; SINGELS, A. The response of sugarcane canopy development to water stress. Field Crops Research, Amsterdam, v.98, p.91-97, 2006.

STREIT, N. M., CANTERlE, L. P., CANTO, M. W. AND HECKTHEUER, L. H. H. As Clorofilas. Ciência Rural, Santa Maria, v.35, n.3, p.748-755, 2005.

SZMRECSÁNYI, T. O planejamento da agroindústria canavieira do Brasil (1930 - 1975)Universidade Estadual de Campinas, São Paulo: HUCITEC/Unicamp, 1979. 540p.

TAIZ, L.; ZEIGER, E. Fisiologia Vegetal. 5. ed. Porto Alegre: Artmed, 2013. 918p.

TEJERA, N. A.; RODÉS, R.; ORTEGA, E.; CAMPOS, R.; LLUCH, C. Comparative analysis of physiological characteristics and yield components in sugarcane cultivars. Field Crops Research, Amsterdam, v.102, p.64 - 72, 2007.

TORRES NETTO, A.; CAMPOSTRINI, E.; OLIVEIRA, J. G.; BRESSAN-SMITH, R. E. Photosynthetic pigments, nitrogen, chlorophyll-a fluorescence and SPAD-502 readings in coffee leaves. Scientia Horticulturae, v. 104, n. 2, p. 199-209, 2005. 
TRENTIN, R; ZOLNIER, S.; RIBEIRO, A.; STEIDLE NETO, A. J. Transpiração e temperatura foliar da cana-de-açúcar sob diferentes valores de potencial matricial. Engenharia Agrícola, Jaboticabal, v.31, n.6, p.1085-1095, 2011.

WIEDENFELD, B. Scheduling water application on drip irrigated sugarcane. Agricultural Water Management, Amsterdam, v.64, p.169-181, 2004.

WU, C. A.; CAMPBELL, D. R. Leaf physiology reflects environmental differences and cytoplasmic background in Ipomopsis (Polemoniaceae) hybrids. American Journal Botany, Saint Louis, v.94, p.1804-1812, 2007. 


\section{CAPÍTULO I}

RESPOSTAS BIOMÉTRICAS DE VARIEDADES DE CANA-DE-AÇÚCAR DE TERCEIRA SOCA SOB REGIME HÍDRICO VARIÁVEL 


\section{CAPÍtUlO I - RESPOSTAS BIOMÉTRICAS DE VARIEDADES DE CANA-DE- AÇÚCAR DE TERCEIRA SOCA SOB REGIME HÍDRICO VARIÁVEL}

\subsection{RESUMO}

A deficiência hídrica é um dos principais fatores que limitam a produção da cana-de-açúcar. O objetivo deste trabalho foi caracterizar biometricamente as variedades da cana-de-açúcar, submetidas a diferentes regimes hídricos. O experimento foi conduzido em uma área de 0,36 hectares, localizada na EMBRAPA Cerrados, Planaltina-DF. O experimento foi conduzido em um delineamento em blocos ao acaso com três repetições em parcelas subdivididas no tempo, com três variedades: RB855156, RB835486 e RB867515 (parcela), ausência e presença da irrigação (irrigado e sequeiro - subparcela) e seis coletas de dados no tempo (50, 100, 150, 200, 250 e 300 dias após o corte - DAC) que foram as subsubparcelas. No experimento a irrigação foi aplicada conforme o sistema Line Source Sprinkler System, de forma que a lâmina de água aplicada no tratamento irrigado foi equivalente a $100 \%$ da Evapotranspiração da cultura (ETc) no centro da área, e as extremidades o cultivo em sequeiro, que só recebeu uma irrigação de salvamento logo após o corte, e suspendendo totalmente o fornecimento de água. Foram avaliadas as características biométricas: diâmetro médio do colmo (DMC), altura média de perfilho altura média do perfiho (AMP), número de folhas verdes completamente abertas (NFVA), comprimento e largura da folha $+3\left(\mathrm{C}+3\right.$ e $\mathrm{L}+3$, respectivamente), índice de área foliar (IAF), área foliar $\left(\mathrm{AF}_{\mathrm{c}}\right)$ e produtividade. Nas avaliações das dimensões foliares, foi utilizada a folha denominada como +3 . Os dados foram submetidos à análise de variância e regressão a p<0,05. A variedade RB867515 foi a que apresentou maiores valores biométricos de DMC, AMP, C+3 e L+3, tanto em cultivo irrigado como em sequeiro; observou-se que houve redução nos números de NFVA por perfilhos quando as variedades foram cultivadas em sequeiro; a variedade RB867515 teve maior produtividade, não diferenciando da RB855156, e se mostraram melhor adaptadas à restrição hídrica ocorrida no início do ciclo do cultivo.

Palavras-chave: Saccharum spp. L., estresse hídrico, crescimento, produtividade. 


\section{BIOMETRIC RESPONSES OF THIRD RATOON SUGARCANE VARIETIES UNDER VARIABLE WATER REGIME}

\subsection{ABSTRACT}

Water deficit is one of the main factors that limit sugar cane production. This paper's goal was to characterize biometrically varieties of sugarcane under different water regimes. The experiment took place in a 0.36 hectare area, in EMBRAPA Cerrados, Planaltina-DF. The experiment was performed using randomised design with three repetitions in parcels subdivided in time, in which three represents each variety: RB855156, RB835486 e RB867515 (plots), with absence and presence of irrigation (irrigated and rainfed - subplots) to which the plants were subjected, and data collection in six observations in time (50, 100, 150, 200, 250 and 300 days after harvest - DAC), that were the subsubplots. In the experiment, irrigation was applied according to Line Source Sprinkler System, so that the water applied in the irrigated treatment was equivalent to $100 \%$ of culture's evapotranspiration (ETc) in the center of the area, and the in extremities the rainfed cultivation, which only received salvage irrigation right after harvest, and totally cutting off water supply. the following biometrics were assessed: average culm diameter (DMC), average tiller height (AMP), number of green and completely open leaves (NFVA), length and width of +3 leaf $(\mathrm{C}+3$ and $\mathrm{L}+3$, respectively), leaf area index (IAF), leaf area (AF) and productivity. In the leaf dimension evaluations, the leaf used was to +3 . The data were subjected to variance analysis and regression at $\mathrm{p}<0.05$. The variety $\mathrm{RB} 867515$ was the one that displayed higher DMC, AMP, C+3 and $L+3$ biometric values, both in irrigated cultivation and rainfed; it was observed that there was decrease in NFVA values per tiller when the varieties were grown rainfed; the RB867515 variety had higher productivity, not differentiating the RB855156, and proved better suited to water stress during the beginning of cultivation cycle.

Keywords: Saccharum spp L., water stress, growth, productivity. 


\subsection{INTRODUÇÃO}

A cana-de-açúcar (Saccharum spp. L.) possui expressiva importância para a economia do Brasil. Seus subprodutos são utilizados em larga escala e com o aumento da demanda do setor sucroalcooleiro (açúcar e álcool), atinge atualmente a produção estimada de 39,46 milhões de toneladas e os Estados de São Paulo, Mato Grosso do Sul, Goiás e Paraná registraram expansão das áreas plantadas com a cultura (CONAB, 2014).

Em algumas áreas agrícolas do Brasil, faz-se necessária a utilização de um sistema de irrigação suplementar que garante total ou parcialmente, o suprimento hídrico às culturas evitando perdas na eficiência produtiva (MATIOLI et al., 1998; BEZERRA et al., 2013). O uso da irrigação proporciona vários benefícios para a agricultura moderna, como também evita o déficit hídrico em fases fenológicas críticas para a cana-de-açúcar, minimizando o risco de perdas econômicas, principalmente ao longo dos períodos com pouca ou nenhuma precipitação pluviométrica, como é o caso do Cerrado brasileiro (MATIOLI et al., 1998; BEZERRA et al., 2013).

Em países tropicais, como o Brasil, fatores ambientais como elevadas temperaturas e longos períodos de estiagens, podem provocar estresse hídrico, diminuindo a área foliar e, conseqüentemente, a aceleração da senescência foliar das folhas verdes, a fim de reduzir a área de perda por transpiração pela superfície da folha, como é o caso de variedades que são consideradas sensíveis à restrição hídrica (INMAN-BAMBER, 2004). A área foliar, dinâmica do crescimento vegetativo e demais índices de crescimento vegetativo das variedades de cana-de-açúcar, estão relacionados à maior eficiência produtiva da cultura em tonelada de colmos por hectare, como também com o acúmulo de açúcares no colmo (OLIVEIRA et al., 2007; LEME et al., 1984; HERMANN; CÂMARA, 1999). As folhas são a parte estrutural responsável pela produção e maior parte dos carboidratos essenciais para o crescimento e desenvolvimento da planta e são responsáveis por até $90 \%$ da massa acumulada (BENINCASA, 1988).

Além da arquitetura foliar, a dinâmica de crescimento dos colmos também é associada à eficiência produtiva do canavial (CARLIN et al., 2008). Essas características são influenciadas diretamente pelas condições ambientais, sistemas de cultivo e variedade plantada (COSTA et al., 2011; INMAN-BAMBER, 2004).

A escolha de variedades tolerantes à deficiência hídrica nas novas áreas de expansão canavieira torna o plantio mais seguro e com maior viabilidade econômica (PEIXOTO et al., 2007; ECCO et al., 2014). A resposta à restrição hídrica pode variar de acordo com o genótipo da cana-deaçúcar (INMAN-BAMBER; SMITH, 2005), e estas incluem desde respostas celulares até modificações morfológicas (PASSIOURA, 1997). Nesse sentido, Shigaki et al. (2004) afirmam que para regiões com períodos de déficit hídrico consideráveis, a escolha correta de variedades reconhecidamente adaptadas às diferentes condições climáticas e edáficas, é o fator limitante para 
uma exploração canavieira mais eficiente e lucrativa e o produtor deve escolher variedades resistentes ao estresse hídrico, e a pragas e doenças.

As variedades de cana-de-açúcar tolerantes à restrição hídrica manifestam suas características na limitação do crescimento vegetativo, adaptações morfológicas, adaptações fisiológicas e alterações no seu metabolismo (CASAGRANDE, 1991). Para isso, a escolha da variedade concomitantemente com um manejo adequado, evitando a ocorrência de restrição hídrica em períodos críticos do ciclo da cultura, é essencial para que os genótipos possam expressar seu potencial genético (ALMEIDA et al., 2008).

Cada genótipo tem suas características particulares, como: número de colmos por planta, dimensões do colmo, nós e entrenós, morfologia foliar, distribuição da parte aérea, como outras. No entanto, a maneira como essas características morfológicas se expressam, varia bastante e dependente das condições ambientais e do manejo da cultura (PASSIOURA, 1997; INMANBAMBER; SMITH, 2005). Estudos sobre o comportamento das variedades de cana-de-açúcar, utilizando análises biométricas de crescimento, são importantes ferramentas para se investigar as diferenças estruturais e funcionais de cada variedade, assim como o potencial produtivo de cada uma, permitindo o uso para estudos de melhoramento genético da cultura (PEREIRA; MACHADO, 1986; HERMANN; CÂMARA, 1999).

É pelo uso da mensuração dos dados biométricos, que se podem observar possíveis reduções no comportamento do crescimento vegetal da cana-de-açúcar, que reduz em estados de deficiência hídrica no cultivo da cultura, podendo destacar o número de folhas a área foliar (INMAN-BAMBER, 2004), a senescência foliar (SMIT; SINGEL, 2006), altura da plantas (ALMEIDA et al., 2008), diâmetro de colmos e o número de perfilhos (SILVA et al., 2012). A área foliar é reduzida (área de captação de a luz solar), em conseqüência ocorre a diminuição da demanda de água pela cultura. A planta também pode reduzir o número de folhar emergentes, o que pode variar de acordo com o potencial genético de cada variedade (INMAN-BAMBER, 2004).

O objetivo deste trabalho foi caracterizar biometricamente as variedades da cana-deaçúcar, submetidas a diferentes regimes hídricos. 


\subsection{MATERIAL E MÉTODOS}

O experimento foi conduzido em condições de campo entre abril de 2013 e abril de 2014, em uma área de 0,36 hectares, localizada na EMBRAPA Cerrados (CPAC), situada na BR

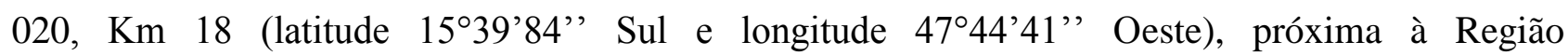
Administrativa de Planaltina-DF. A altitude da área é de aproximadamente $1014 \mathrm{~m}$ com temperatura e pluviosidade média anual de $21,9^{\circ} \mathrm{C}$ e $1.395,6 \mathrm{~mm}$, respectivamente.

O clima da região é classificado como tropical estacional (Aw), conforme Köppen (BRASIL, 1972), sendo caracterizado por duas estações bem definidas: seca e chuvosa. Pode haver a ocorrência de períodos de estiagem (veranicos) durante a estação chuvosa (SANO et al., 2008).

Os dados de precipitação pluviométrica, evapotranspiração de referência (ETo), temperatura máxima $\left({ }^{\circ} \mathrm{C}\right)$, temperatura mínima $\left({ }^{\circ} \mathrm{C}\right)$ e temperatura média durante a condução do experimento estão apresentados na Figura 1.

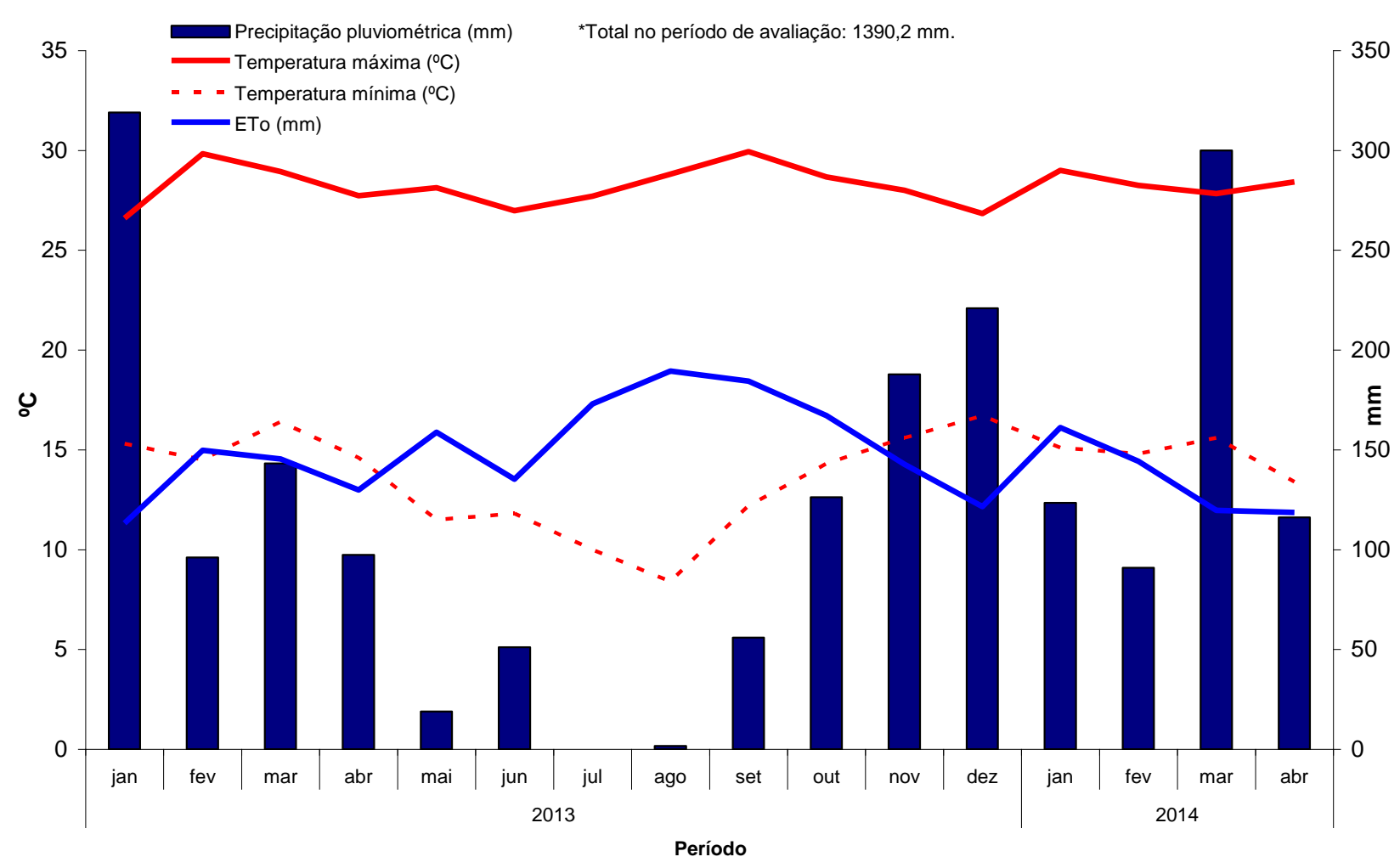

Figura 1. Precipitação pluviométrica, evapotranspiração de referência (ETo), temperatura máxima $\left({ }^{\circ} \mathrm{C}\right)$, temperatura mínima $\left({ }^{\circ} \mathrm{C}\right)$ da Região Administrativa de Planaltina-DF durante $\mathrm{o}$ período de 05/05/2013 a 24/04/2014. Dados coletados na Estação Meteorológica da Embrapa Cerrados, Planaltina-DF (2013).

O solo da área experimental é classificado como um Latossolo Vermelho Distrófico Típico, textura argilosa, A moderado (EMBRAPA, 2006) e sua caracterização química antes da instalação do experimento está apresentada na Tabela 1. 
Tabela 1. Caracterização química do solo da área de cultivo da cana-de-açúcar. Embrapa Cerrados, Planaltina-DF (2013).

\begin{tabular}{|c|c|c|c|c|c|c|c|c|}
\hline $\begin{array}{c}\text { Profundidade } \\
----\mathrm{cm}--- \\
\end{array}$ & $\mathrm{pH} \mathrm{H} \mathrm{H}_{2} \mathrm{O}$ & $\begin{array}{c}\mathrm{Al} \\
--\mathrm{cmol}_{\mathrm{c}} \mathrm{dm}^{-3}--\end{array}$ & $\begin{array}{c}\mathrm{P} \\
---\mathrm{m}\end{array}$ & $\begin{array}{c}\mathrm{K} \\
\mathrm{n}^{-3}-\cdots \\
\end{array}$ & $\mathrm{Ca}$ & $\begin{array}{l}\mathrm{Mg} \\
=\mathrm{mol}_{\mathrm{c}} \mathrm{dr}\end{array}$ & $\mathrm{H}+\mathrm{Al}$ & $\begin{array}{c}\mathrm{MO} \\
---\%-- \\
\end{array}$ \\
\hline $0-20$ & 5,08 & 0,39 & 0,22 & 8,00 & 0,56 & 0,26 & 3,70 & 0,87 \\
\hline $20-40$ & 5,20 & 0,04 & 0,50 & 16,00 & 1,19 & 0,68 & 3,46 & 1,15 \\
\hline $40-60$ & 5,16 & 0,13 & 0,76 & 32,00 & 0,96 & 0,52 & 3,30 & 1,30 \\
\hline $60-80$ & 5,13 & 0,19 & 0,83 & 22,00 & 1,08 & 0,44 & 3,18 & 1,30 \\
\hline $80-100$ & 5,10 & 0,24 & 0,81 & 30,00 & 0,99 & 0,53 & 3,60 & 1,30 \\
\hline $100-120$ & 5,34 & 0,09 & 0,58 & 18,00 & 1,41 & 0,68 & 2,98 & 0,99 \\
\hline $120-140$ & 5,22 & 0,25 & 0,73 & 18,00 & 0,91 & 0,47 & 3,84 & 1,27 \\
\hline $140-160$ & 5,03 & 0,32 & 0,66 & 12,00 & 0,77 & 0,37 & 3,88 & 0,97 \\
\hline $160-180$ & 5,01 & 0,37 & 0,37 & 12,00 & 0,72 & 0,38 & 3,78 & 1,13 \\
\hline $180-200$ & 5,13 & 0,27 & 0,39 & 4,00 & 0,92 & 0,46 & 3,54 & 0,82 \\
\hline $200-220$ & 5,20 & 0,14 & 0,39 & 4,00 & 0,97 & 0,44 & 3,32 & 1,14 \\
\hline $220-240$ & 5,25 & 0,09 & 0,42 & 8,00 & 1,09 & 0,49 & 3,36 & 0,94 \\
\hline
\end{tabular}

Foi realizada na área uma adubação corretiva (a lanço e incorporada) de $500 \mathrm{Kg} \mathrm{ha}^{-1}$ de gesso e $50 \mathrm{~kg} \mathrm{ha}^{-1}$ de FTE BR-10 (pó) como fonte de micronutrientes ( $\mathrm{Zn}, \mathrm{B}, \mathrm{Cu}, \mathrm{Fe}$, Mn e Mo com 7,0, 2,5, 1,0, 4,0, 4,0 e 0,1\% respectivamente) e, em seguida, a adubação de plantio, na dose de 600 $\mathrm{kg} \mathrm{ha}^{-1}$ de NPK na formulação 04-30-16. O plantio da cana-de-açúcar foi realizado de forma manual em 18 de junho de 2010, sendo utilizadas três variedades, a RB855156, RB835486 ambas de maturação precoce e a RB867515 como variedade de referência por ser a mais plantada no Brasil (CAMARGO; VITTI, 2014).

A adubação de cobertura foi aplicada de forma manual e após o primeiro corte das plantas, foi realizada em dois períodos, no início de maio na dose de $400 \mathrm{~kg} \mathrm{ha}^{-1}$ de NPK (formulação 20-00-20) e em novembro de 2011 na dose de $600 \mathrm{~kg} \mathrm{ha}^{-1}$ de NPK (formulação 20-0024), repetindo-se esta mesma adubação nos anos posteriores.

Em maio de 2011 foi realizado o primeiro corte da cana-planta e após a nova brotação do canavial foi feito o segundo corte da cana-soca em abril de 2012; o terceiro corte da foi realizado em maio de 2013 e o quarto corte em abril de 2014. Aproximadamente de 20 a 30 dias após cada corte, foi feita uma irrigação de salvamento com uma lâmina de água de aproximadamente $60 \mathrm{~mm}$ devido à baixa precipitação neste período. As três variedades de cana (RB855156, RB835486 e RB867515) foram submetidas a dois regimes hídricos: Irrigado (I) e Sequeiro (S).

O manejo da irrigação foi realizado com base na metodologia Penman-Monteith (MONTEITH, 1965), recomendado pela FAO (SMITH, 1991) e nos dados climatológicos, coletados nos meses de janeiro de 2013 a abril de 2014 na estação meteorológica localizada a 100m do experimento. Na área experimental, a irrigação foi realizada conforme o sistema Line Source Sprinkler System, descrito por Hanks et al. (1976), em que a lâmina de água aplicada na cultura descresse do centro para as extremidades da área (Figura 2). 


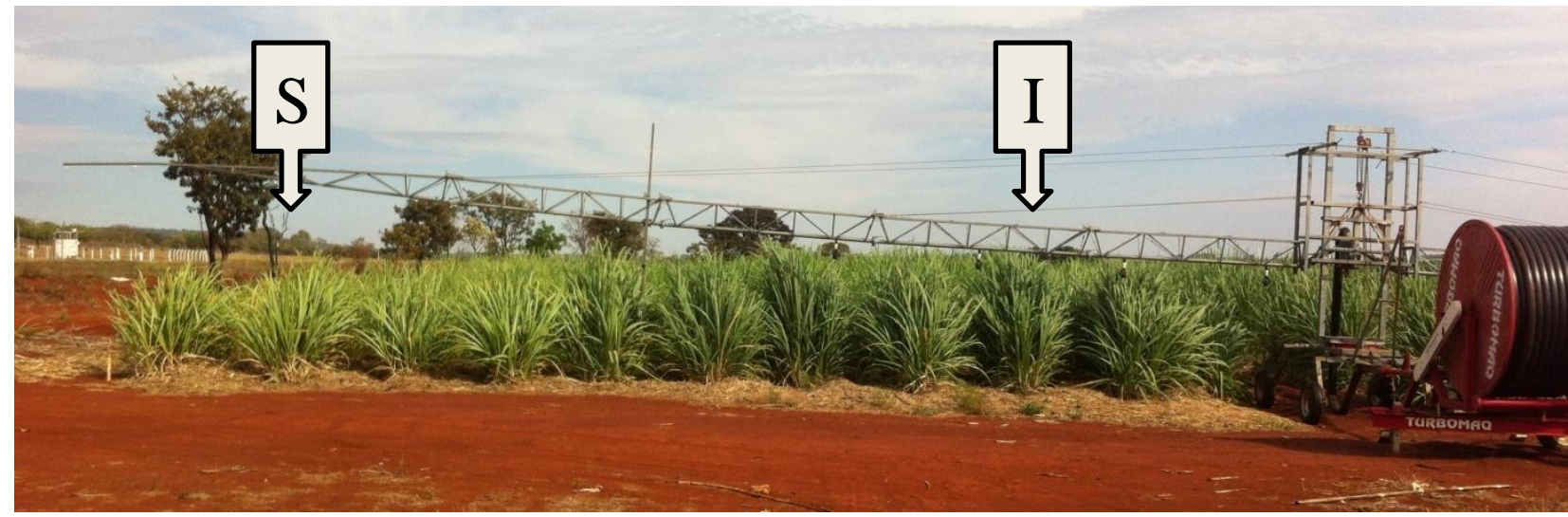

Figura 2. Sistema Line Source Sprinkler System, mostrando as parcelas experimentais: sequeiro (S) e irrigada (I). Embrapa Cerrados, Planaltina-DF (2013).

$\mathrm{O}$ experimento foi conduzido em um delineamento em blocos ao acaso com três repetições em parcelas subdivididas no tempo, com três variedades: RB855156, RB835486 e RB867515 (parcela), ausência e presença da irrigação (irrigado e sequeiro - subparcela) e seis coletas de dados no tempo (50, 100, 150, 200, 250 e 300 dias após o corte - DAC) que foram as subsubparcelas. Cada parcela foi composta por uma fileira de plantas com 4,0 $\mathrm{m}$ de comprimento e 1,5 m de largura, sendo a área útil formada pelos 3,0 $\mathrm{m}$ centrais da mesma, descartando-se 0,5 $\mathrm{m}$ de cada lado para evitar o efeito da bordadura.

Para o tratamento irrigado, as parcelas foram irrigadas em turno de rega fixo com intervalos de 9 dias, e receberam lâminas de irrigação que corresponderam a $100 \%$ da evapotranspiração da cultura (ETc), estimada através do balanço climatológico, utilizando-se a irrigação via sistema autopropelido com barra irrigadora (Figura 2) com bocais conjugados e emissores XI-Wobbler.

Para o tratamento de sequeiro o suprimento hídrico foi completamente suspenso após a irrigação de salvamento, na tentativa de reproduzir a realidade dos sistemas de produção de algumas usinas da região Centro-Oeste, que tem canaviais implantados em áreas sob longos períodos de deficiência hídrica devido à estacionalidade pluviométrica (Figura 2).

Após o quarto corte, as três variedades de cana-de-açúcar foram avaliadas quanto a suas respostas biométricas ao longo do período de cultivo. Para os diferentes características analisadas, cinco plantas de cada variedade foram coletadas de forma aleatória na área útil. Foram avaliados os seguintes características biométricas: diâmetro médio do colmo (DMC), altura média do perfilho (AMP), número de folhas verdes completamente abertas (NFVA), comprimento e largura da folha +3 (C+3 e L+3, respectivamente), índice de área foliar (IAF) e área foliar $\left(\mathrm{AF}_{\mathrm{c}}\right)$ e produtividade. Nas avaliações das dimensões foliares, foi utilizada a folha denominada como +3 , de acordo com o 
sistema de Kuijper (DILLEWIJN, 1952), por ser completamente desenvolvida do ponto de vista fisiológico e totalmente desenrolada morfologicamente.

A AMP foi mensurada por meio da utilização de uma trena graduada, medindo-se do nível do solo até a altura da projeção da folha mais alta do perfilho selecionado.

O NFVA foi quantificado em cada um dos perfilhos selecionados, considerando todas as folhas completamente abertas a partir da folha +1 (DILLEWIJN, 1952). Foram considerados como folhas verdes as que possuíam $50 \%$ do limbo foliar visualmente verde e que se apresentavam completamente expandidas (SILVA, 2012).

Os dados de L+3 e C+3 foram obtidos pelas medições na porção mediana e nos pontos extremos das folhas +3 , respectivamente, por meio de uma trena.

O IAF foi determinado por meio do equipamento LAI-2000 Plant Canopy Analyzer (LICOR ${ }^{\circledR}$ Biosciences). O aparelho foi configurado para realizar sete leituras, sendo uma acima do dossel e seis abaixo, ao nível do solo, repetindo o procedimento para cada uma das cinco plantas selecionadas aleatoriamente.

$A$ área foliar $\left(A F_{c}\right)$ foi calculada pela equação de Hermann e Câmara (1999): $A_{c}=C x$ L x 0,75 x $(\mathrm{N}+2)$, onde: $\mathrm{AFc}=$ área foliar do colmo $\left(\mathrm{em}^{2} \mathrm{~cm}^{2} ; \mathrm{C}=\right.$ comprimento da folha +3 (cm); L = largura da folha $+3(\mathrm{~cm}) ; 0,75=$ fator de forma; $\mathrm{N}=$ número de folhas totalmente abertas e com pelo menos $20 \%$ de área verde (folha 0 até folha +7 ); 2 = fator de correção.

A colheita do experimento no quarto corte da cana-de-açúcar foi realizada de forma manual, iniciando no dia 04 de abril de 2014, aos 335 dias após o corte (DAC). Os colmos da área útil da parcela foram colhidos, correspondendo à subparcela em regime de sequeiro (0\% da ETc) e da subparcela de regime irrigado (100\% ETc); despalhados, contados e pesados para a determinação da produtividade, que foi expresso em megagrama de colmos por hectare $\left(\mathrm{Mg} \mathrm{ha}^{-1}\right)$. Para a pesagem dos colmos, utilizou-se uma balança Kern HCB Modelo 99K50.

Os dados foram submetidos à análise de Normalidade pelo teste Shapiro-Wilk, analisando a significância a 5\%; análise de Homocedase a significância a 5\%, pelo teste de Levene para verificar possíveis heterocedasticidade dos erros; e a Independência dos dados pelo teste de Durbin-Watson. Em seguida os dados foram submetidos à análise de variância e regressão polinomial pelo teste $\mathrm{F}$ a $5 \%$ de probabilidade, e as médias comparadas pelo teste Tukey a 5\% de probabilidade. Para a análise foi utilizado o software para análises estatísticas Sisvar (FERREIRA, 2011). 


\subsection{RESULTADOS E DISCUSSÃO}

De acordo com os resultados da análise de variância, verifica-se que todas as características biométricas avaliadas, com exceção da produtividade, foram significativas para as variedades estudados (V), como também para o regime hídrico nas diferentes dias após o corte (DAC). As características AMP, C+3, NFVA e $\mathrm{AF}_{\mathrm{c}}$ foram significativos para a interação variedade V x RH x DAC, conforme apresentado na Tabela 2.

Tabela 2. Resumos da análise de variâncias dos parâmetros fisiológicos: Diâmetro médio do colmo (DMC), altura média do perfilho (AMP), comprimento $(\mathrm{C}+3)$ e largura $(\mathrm{L}+3)$ da folha +3 , número de folhas verdes completamente abertas (NFVA), área foliar $\left(\mathrm{AF}_{\mathrm{c}}\right)$, índice de área foliar (IAF) e produtividade das variedades RB835486, RB855156 e RB867515 de cana-de-açúcar, cultivadas em sistema irrigado e em sequeiro. Embrapa Cerrados, Planaltina-DF (2013).

\begin{tabular}{|c|c|c|c|c|c|c|c|c|c|c|}
\hline \multirow{2}{*}{$\mathrm{FV}$} & \multirow{2}{*}{ GL } & \multicolumn{7}{|c|}{ Quadrado médio } & \multirow{2}{*}{ GL } & \multirow[b]{2}{*}{ Produtividade } \\
\hline & & DMC & AMP & $\mathrm{C}+3$ & $L+3$ & NFVA & $\mathrm{AF}_{\mathrm{c}}$ & IAF & & \\
\hline Bloco & 2 & $12,14^{\mathrm{ns}}$ & $0,03^{\mathrm{ns}}$ & $187,69^{\mathrm{ns}}$ & $0,14^{\mathrm{ns}}$ & $0,41^{\mathrm{ns}}$ & $762110,18^{\mathrm{ns}}$ & $0,10^{\mathrm{ns}}$ & 2 & $446,06^{\mathrm{ns}}$ \\
\hline Variedade (V) & 2 & $174,92 *$ & $2,25 * *$ & $1123,51 *$ & $11,54 * *$ & $30,67 * *$ & $12831579,15^{* *}$ & $1,65^{*}$ & 2 & $2187,06^{*}$ \\
\hline Resíduo a & 4 & 11,00 & 0,07 & 115,75 & 0,05 & 1,16 & 537379,83 & 0,12 & 4 & 340,22 \\
\hline RH & 1 & $545.85 * *$ & $2,68 * *$ & $2438,65 * *$ & $8,00 * *$ & $47,20 * *$ & $37525919,58 * *$ & $12,00 * *$ & 1 & $650,71^{\mathrm{ns}}$ \\
\hline V x RH & 2 & $1,85^{\mathrm{ns}}$ & $0,01^{\mathrm{ns}}$ & $380,65^{\text {ns }}$ & $0,10^{\mathrm{ns}}$ & $5,35^{* *}$ & $1529775,18 * *$ & $0,12^{\mathrm{ns}}$ & 2 & $141,72^{\mathrm{ns}}$ \\
\hline Resíduo b & 6 & 1,80 & 0,04 & 82,84 & 0,05 & 0,41 & 104625,44 & 0,18 & 6 & 544,06 \\
\hline ID & 5 & $1025,22 * *$ & $25,56 * *$ & $13722,62 * *$ & $30,05 * *$ & $88,72 * *$ & $134094421,00 * *$ & $33,67 * *$ & - & - \\
\hline V x DAC & 10 & $11,29 * *$ & $0,22 * *$ & $50,35 *$ & $0,34 * *$ & $3,01 * *$ & $1151617,16^{* * *}$ & $0,13^{\mathrm{ns}}$ & - & - \\
\hline $\mathrm{RH} \times \mathrm{DAC}$ & 5 & $33,28 * *$ & $0,25 * *$ & 304,17 ** & $0,48 * *$ & $5,71 * *$ & $2447410,25 * *$ & $0,09^{\text {ns }}$ & - & - \\
\hline V x RH x DAC & 10 & $2,28^{\text {ns }}$ & $0,09 *$ & $96,13 * *$ & $0,06^{\mathrm{ns}}$ & $0,64 * *$ & $477582,98 * *$ & $0,16^{\mathrm{ns}}$ & - & - \\
\hline Resíduo c & 60 & 1,58 & 0,04 & 21,83 & 0,06 & 0,21 & 128781,08 & 0,09 & - & - \\
\hline Média & & 28,60 & 2,50 & 144,28 & 4,27 & 5,62 & 4449,34 & 3,36 & & 154,28 \\
\hline CV1 (\%) & & 11,60 & 10,18 & 7,46 & 5,48 & 19,17 & 16,48 & 10,23 & & 11,96 \\
\hline CV2 (\%) & & 4,69 & 7,58 & 6,31 & 5,35 & 11,44 & 7,27 & 12,54 & - & 15,12 \\
\hline VC3 $(\%)$ & & 4,39 & 7,68 & 3,24 & 5,81 & 8,08 & 8,07 & 8,96 & - & - \\
\hline
\end{tabular}

FV: fonte de variação; GL: grau de liberdade; CV: coeficiente de variação; c: colmo; ns: não significativo; * e **: respectivamente significativo para $\mathrm{p}<0,05$ e $\mathrm{p}<0,01$.

A variedade RB867515 foi a que apresentou tendência com maiores valores durante o ciclo da cultura para o DMC em regime irrigado (Figura 3A) e AMP quando cultivadas tanto para em regime irrigado como para sequeiro (Figura 3C e D). Por outro lado, a variedade RB835486 foi a que obteve os menores valores de AMP, tanto em regime irrigado como em sequeiro (Figura 3C e D), no entanto, foi observado que logo após o início do período chuvoso (137 DAC), no cultivo em regime de sequeiro, mesmo com valores inferiores as outras variedades testadas, esta aumentou a sua velocidade de crescimento chegando aos 300DAC com altura de perfilho semelhante a variedade RB855156 (Figura 3D). 
IRRIGADO

(A)

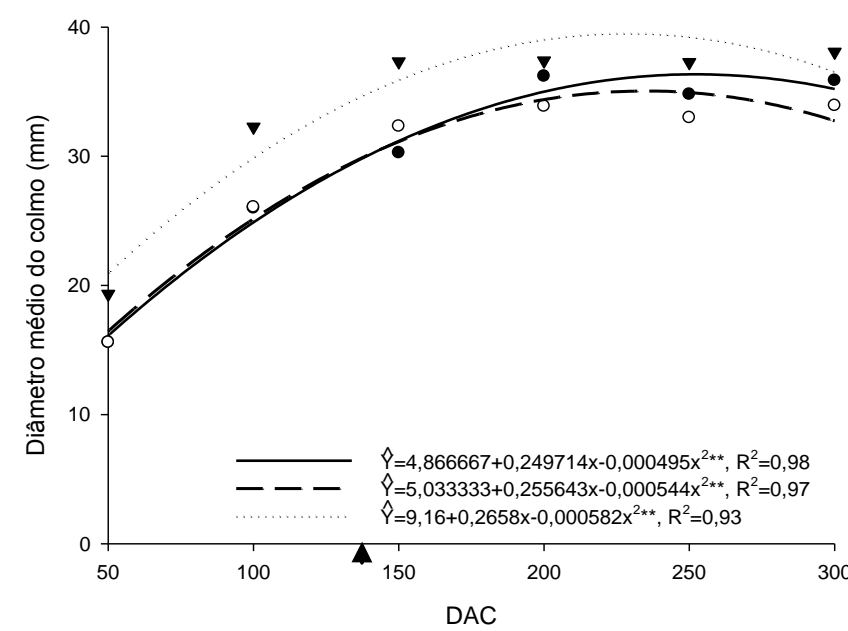

(C)

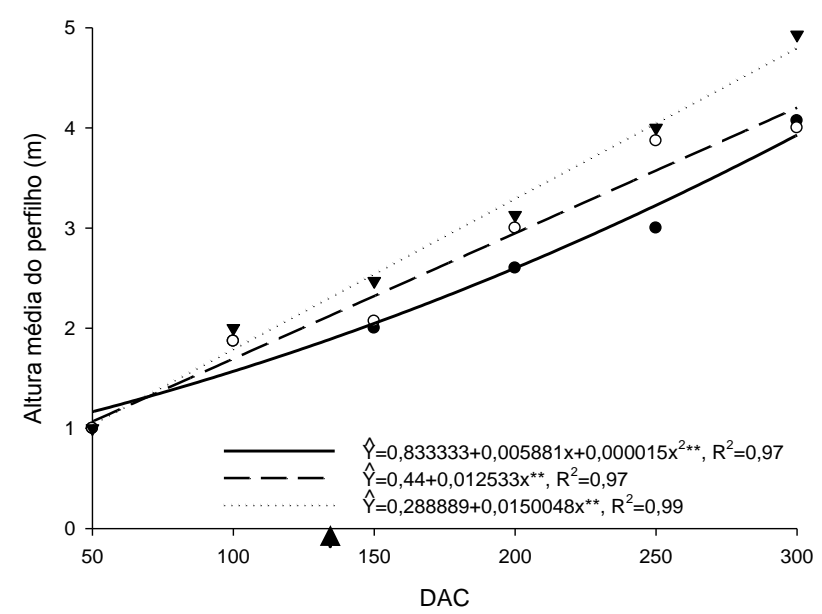

SEQUEIRO

(B)

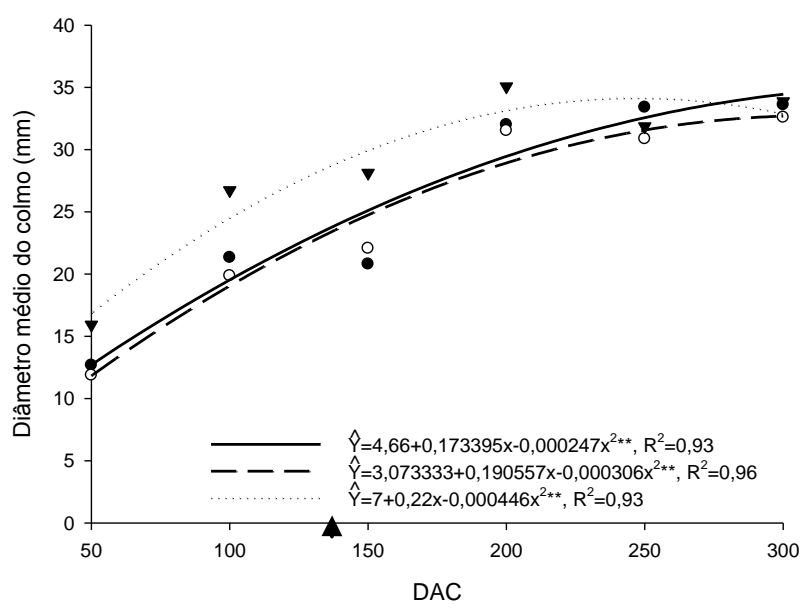

(D)

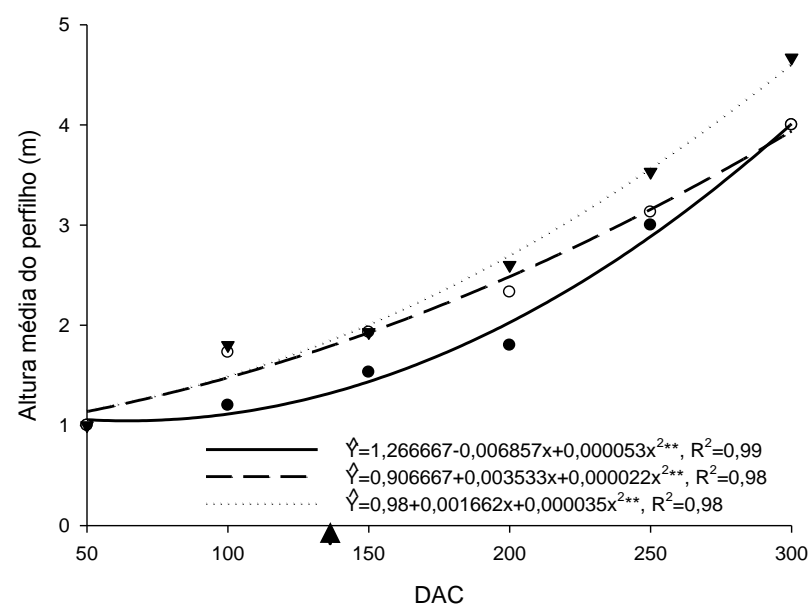

Figura 3. Diâmetro médio do colmo (DMC) e altura média do perfilho (AMP) das variedades RB835486 (- •), RB855156 (----- ০) e RB867515 (...... $\mathbf{\nabla})$ de cana-de-açúcar, cultivadas em sistema irrigado e em sequeiro, em função dos dias após o corte (DAC). Embrapa Cerrados, Planaltina-DF (2013). ( $\mathbf{\Delta}$ ) - início do período chuvoso.

No DMC, a RB867515 atingiu o valor máximo aos 228 dias de cultivo, chegando a $39,51 \mathrm{~mm}$ nos tratamentos sob irrigação. No entanto, quando cultivada em sequeiro, houve decréscimo de 13\% deste valor. As variedades RB835486 e RB855156 atingiram valores de DMC máximo aos 252 e 243 DAC, com valores de 36,36 e $35,02 \mathrm{~mm}$, respectivamente no cultivo irrigado. No cultivo em sequeiro, para estas cultivares, foi verificada redução de $6,94 \%$ e $6,62 \%$, ambas com redução no DMC menor que para a RB867515 (Figuras 3A e B).

O DMC apresentou resultados superiores aos observados por Silva et al. (2012) quando estudaram a cana soca irrigada no Submédio do Vale do São Francisco. Os autores observaram que o crescimento foi mais expressivo nos primeiros 100 dias do ciclo da cultura e com o DMC de 26,7 mm a partir dos 132 DAC, sendo que, após este período a cultura apresentou valores constantes. 
Para os tratamentos em regime irrigado, os valores obtidos foram superiores aos de Costa et al. (2011) e semelhantes aos de Almeida et al. (2008) para o cultivo da cana soca irrigada. A redução dos valores de DMC e redução na velocidade de crescimento e estabilização dos valores de AMP é uma resposta esperada para a fase fenológica de maturação do colmo, o que ocorre por vota dos 300 dias do ciclo da cultura sendo uma resposta à fase fenológica de maturação do colmo, onde a planta mantém as atividades metabólicas, conforme afirmaram Oliveira et al. (2007).

Para a AMP, quando cultivadas em sequeiro houve redução na velocidade de crescimento no início do ciclo, recuperando com a retomada das chuvas na região que ocorreu por aos 137 DAC, sendo, no entanto a variedade RB835486 a que houve uma maior redução inicial na altura média dos perfilhos. O início das chuvas favoreceu a recuperação da AMP ao longo do ciclo da cultura, não se verificando diferenças marcantes para a altura das plantas ao final do ciclo (Figuras 3C e D), onde a RB867515 apresentou resultados superiores às demais variedades estudadas, mostrando que as plantas tiveram recuperação satisfatória com a precipitação pluviométrica ocorrida no Cerrado. Os resultados do presente trabalho estão de acordo com Ido (2003); o autor afirma que crescimento mais expressivo da parte aérea em cultivos de sequeiro, é entre janeiro e abril, com a presença de precipitação e temperatura favorável. Os valores de AMP obtidos no presente trabalho foram superiores aos registrados por Machado et al. (2009) ao estudarem respostas biométricas e fisiológicas ao déficit hídrico em diferentes fases fenológicas de variedades da cana-de-açúcar. Tais resultados reforçam o estudo destas características biométricas como indicativo de tolerância ao estresse hídrico para a cana-de-açúcar como proposto por Silva et al. (2012).

A limitação no crescimento é considerada como o primeiro mecanismo de defesa da cultura ao déficit hídrico. As atividades que dependem da turgidez celular ficam comprometidas, sendo as primeiras a expressarem resposta à menor disponibilidade de água na planta, pela redução da área foliar e crescimento radicular (TAIZ; ZEIGER, 2013). Com isso, ocorre uma diminuição na área superficial de transpiração, conservando um suprimento mínimo de água no solo por um período maior (PUGNAIRE et al., 1994; TAIZ; ZEIGER, 2013). De acordo com Inman-Bamber (2004) o crescimento da planta é diretamente afetado em situações de restrição hídrica, pois o alongamento e divisão celular são reduzidos, causando decréscimo na expansão das folhas e crescimento do colmo, o que pode também influenciar na qualidade final do produto por reduzir o acúmulo de sólidos solúveis do colmo. Koehler (1982) explica que uma planta em condições de estresse hídrico pode ter seu crescimento reduzido em até $80 \%$. 
O comprimento da folha +3 foi verificado que as plantas irrigadas chegaram ao valor máximo 163,15; 137,54 e 163,15 cm aos 255,74; 243,97 e 290,32 DAP para as variedades RB835486, RB855156 e RB867515, respectivamente (Figura 4A). Estas variedades sob sequeiro foi observado um desenvolvimento mais lento comparado ao cultivo irrigado, e estas variedades atingiram 163,38; 174,67 e 178,72 cm aos 300 DAC (Figura 4B). Estes resultados são superiores aos $146 \pm 6 \mathrm{~cm}$ (máximos aos 238 DAC) observados por Silva et al. (2012) quando estudaram a biometria da parte aérea da cana soca da variedade RB92579, cultivada sob irrigação no Submédio do Vale do São Francisco. A variedade RB867515 foi a que apresentou maiores valores para o comprimento e largura da folha +3 , tanto para os tratamentos irrigados como em sequeiro, o que confirma a sua boa adaptação à restrição hídrica. Foi possível observar ainda que, durante o período de estresse hídrico, em relação aos tratamentos irrigados, houve redução da largura da folha +3 e recuperaram a mesma com o início do período chuvoso (Figuras 4C e D). 
IRRIGADO

(A)

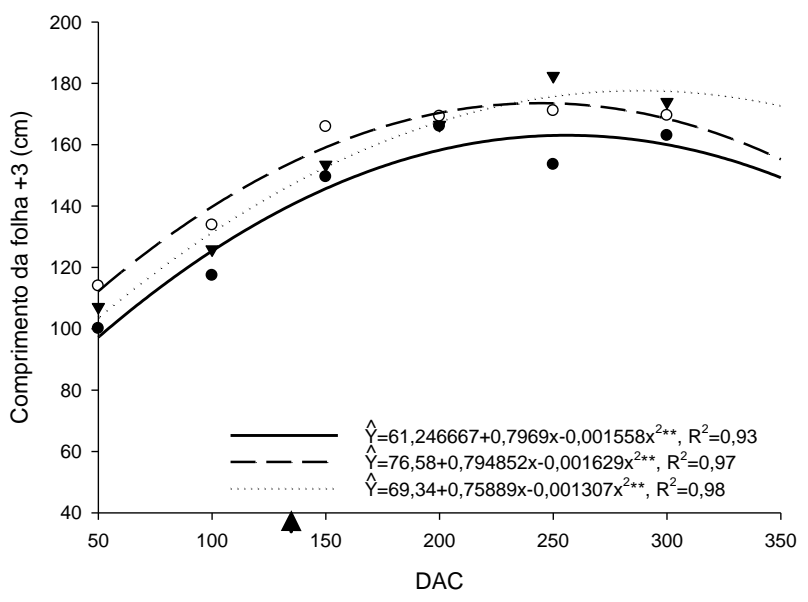

(C)

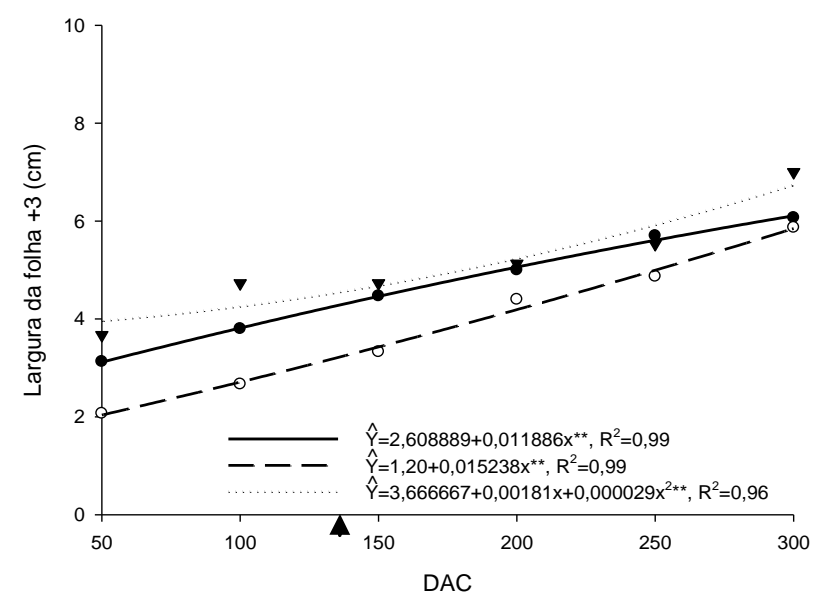

SEQUEIRO

(B)

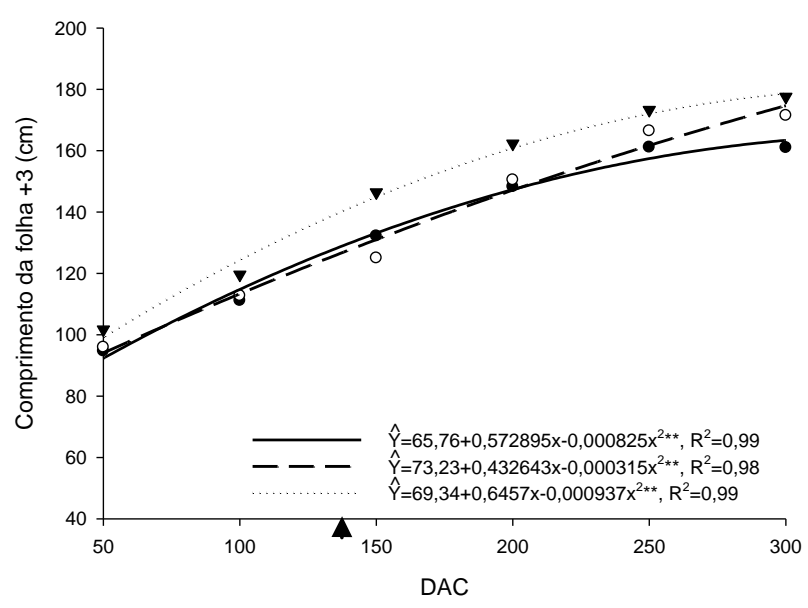

(D)

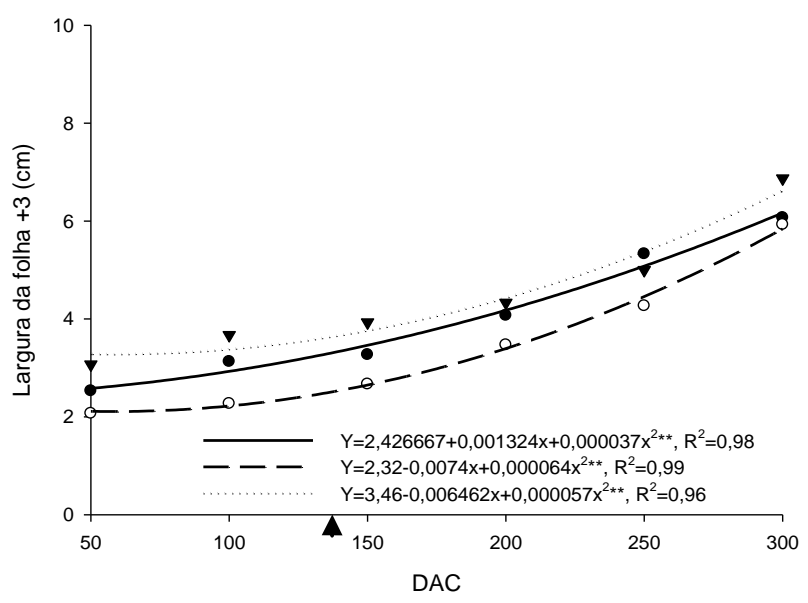

Figura 4. Comprimento da folha $+3(\mathrm{C}+3)$, largura da folha $+3(\mathrm{~L}+3)$ de perfilhos das variedades RB835486 (- •), RB855156 (----- ০) e RB867515 (...... $)$ ) de cana-de-açúcar, cultivadas em sistema irrigado e em sequeiro, em função dos dias após o corte (DAC). Embrapa Cerrados, Planaltina-DF (2013). ( ( ) - início do período chuvoso.

Quando em regime sob irrigação as variedades RB835486, RB867515 e RB855156 responderam de forma quadrática durante o ciclo de cultivo e atingiram o máximo de 6,75; 7,55 e 9,65 de NFVA perfilho ${ }^{-1}$, aos 300, 227,36 e 296,51 DAC, respectivamente. Já para o cultivo em sequeiro, observa-se que o surgimento de folhas verdes foi mais lento, chegando aos 300 DAC com 6,82; 7,79 e 8,09 NFVA perfilho-1 (Figuras 5A e B). Com exceção da variedade RB855156, a redução das folhas verdes no cultivo em regime de sequeiro causado com maior intensidade nas variedades RB835486 e RB867515. 
IRRIGADO

(A)

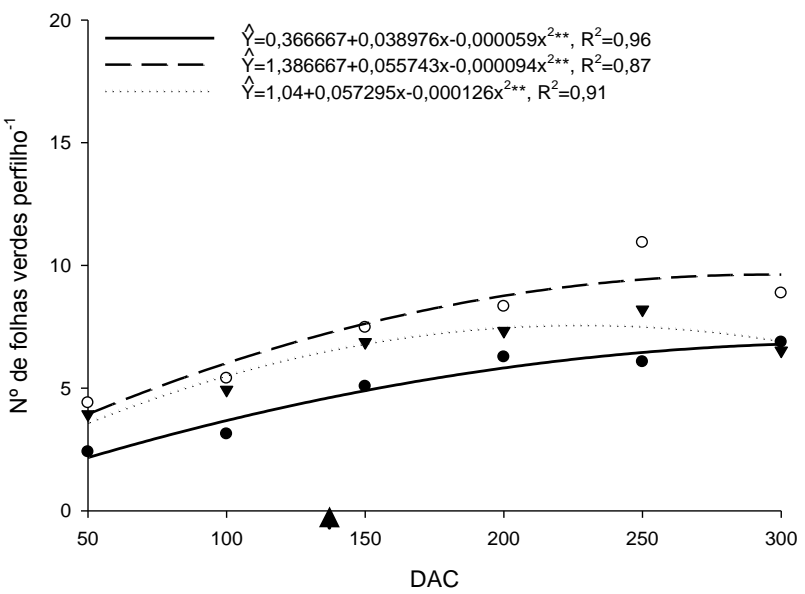

SEQUEIRO

(B)

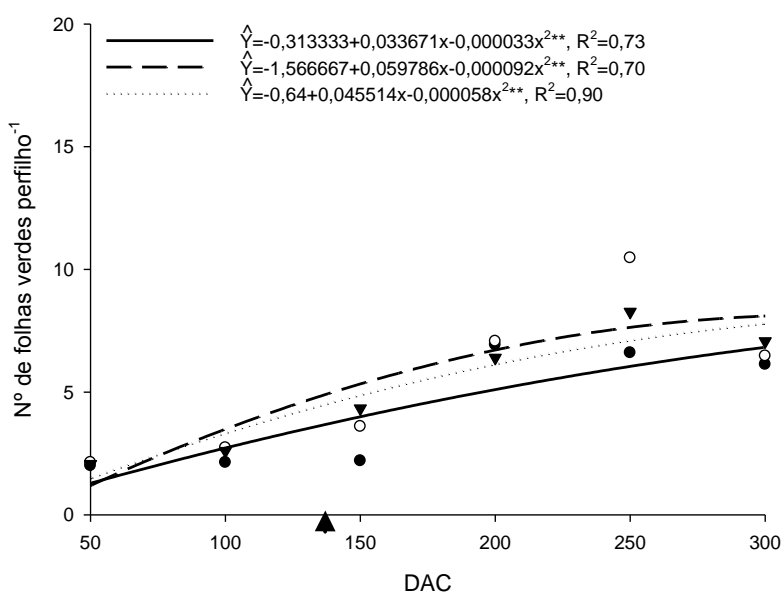

Figura 5. Número de folhas verdes completamente abertas (NFVA) por perfilhos das variedades RB835486 (- •), RB855156 (----০) e RB867515 (...... $\mathbf{\nabla})$ de cana-de-açúcar, cultivadas em sistema irrigado e em sequeiro, em função dos dias após o corte (DAC). Embrapa Cerrados, Planaltina-DF (2013). ( $\mathbf{\Delta}$ ) - início do período chuvoso.

Resultados semelhantes foram obtidos por Oliveira et al. (2007) para as variedades RB72454, RB855113 e RB855536, verificando valores máximos no NFVA entre 8 e 9, embora houve menor número de folhas até os 231 DAP; período este que corresponde ao final da fase de maior perfilhamento da cana-de-açúcar. A partir desta época, os autores afirmam que ocorreu aumento no número de folhas verdes, culminando aos 377 DAP, para as variedades RB72454 e RB855113, e aos 428 DAP para a variedade RB855536. Os resultados para o NFVA também corroboram com os registrados por Machado et al. (2009); os autores verificaram que sob estresse hídrico houve redução no número de folhas verdes, embora não tenham observado diferenças entre as variedades testadas, já que esta é uma resposta também dependente do potencial genético de cada variedade (SMIT; SINGELS, 2006).

Machado et al. (2009) também registraram tendências semelhantes ao estudarem as respostas biométricas e fisiológicas das variedades IACSP 94-2094 e IACSP 96-2042 de cana-deaçúcar em diferentes fases fenológicas e observaram que o numero de folhas verdes por colmo foi entre 8 e 10, apresentando reduções quando cultivadas sob déficit hídrico. Já Silva et al. (2012) registrou valores de 6 a 8 para o NFVA ao avaliarem a cana soca da variedade RB92579 em cultivo irrigado no Submédio do Vale do São Francisco, observando ainda que os valores reduziram ao final do ciclo em decorrência da diminuição da emissão pelas plantas e do aumento da taxa de senescência, chegando ao maior valor de NFVA ( 8 folhas colmo $\left.{ }^{-1}\right)$ entre 200 e 250 DAC.

A redução no NFVA é provavelmente decorrente do final da fase de intenso crescimento (279 a 377 DAP), onde a cana-de-açúcar diminui o gasto de energia para a produção de folhas verde (RAMESH, 2000). Esta redução no número de folhas verdes também é relatada 
quando as plantas cultivadas com déficit hídrico, e é atribuída à estratégia para redução da superfície transpirante, reduzindo o gasto metabólico para a manutenção dos tecidos (INMANBAMBER; SMITH, 2005; SMIT; SINGELS, 2006; INMAN-BAMBER, 2004; INMAN-BAMBER et al., 2008). A conseqüente redução na quantidade de folhar na planta provocada pela paralisação do surgimento de folhas forem respostas ao déficit hídrico, o que pode ocorrer de forma variada de acordo com cada genótipo (SMIT; SINGELS, 2006), e ao mesmo tempo sendo o NFVA um provável indicador do efeito do déficit hídrico em cana-de-açúcar, conforme sugerido por InmanBamber (2004). Essa redução do NFVA no cultivo em sequeiro reforça a justificativa de que as plantas de cana-de-açúcar quando submetidas à situação de déficit hídrico que, além de acelerar a senescência das folhas mais velhas, que pode estar relacionada ao aumento na síntese de ácido abcísico (ABA) provocando maior queda de folhas já senescentes decorrentes da redução no suprimento de água para a planta (RAMESH, 2000; TAIZ; ZEIGER, 2013), podem reduzir o numero de folhar emergentes, o que pode variar de acordo com o potencial genético de cada variedade. A diminuição na abertura e crescimento das folhas é afetada pela baixa absorção de água, o que faz com que a planta acumule as folhas no cartucho por mais tempo, diminuindo assim a superfície foliar e conseqüentemente a demanda por água, porém, a planta retorna ao seu crescimento normal quando o suprimento de água normalize ao exigido pela planta (INMANBAMBER, 2004).

A variedade RB867515 também apresentou os maiores valores para a característica $\mathrm{AF}_{\mathrm{c}}$ sob sequeiro (Figura 6). Porém, mesmo com valores inferiores, as variedades RB855156 e RB835486 responderam de maneira semelhante para as duas variáveis $\mathrm{AF}_{\mathrm{c}}$ e IAF (Figura 6), analisadas na arquitetura foliar dos perfilhos, sendo a variedade RB835486 a que apresentou menor IAF que as outras variedades, sendo mais acentuado no período de estresse hídrico. Sob irrigação, os genótipos apresentaram aumento da área foliar, sendo obtidos os valores: 9001,60; 8973,59 e $7001,85 \mathrm{~cm}^{2}$ aos 300 DAC para as variedades RB867515, RB855156 e RB835486 respectivamente. Para o cultivo em sequeiro foi observada uma rápida recuperação na $\mathrm{AF}_{\mathrm{c}}$ e no IAF dos perfilhos, atingindo aos 300 DAC os valores: 9213,39; 7689,82 e 7102,36 $\mathrm{cm}^{2}$. A RB855156 foi a que menos se recuperou com o início do período chuvoso, provocando perda de $14 \%$ na sua área foliar em sistema de sequeiro (Figuras 6A e B). As demais variedades (RB835486 e RB867515) se recuperaram, chegando ao final do ciclo com valores semelhantes aos dos tratamentos com irrigação. 
IRRIGADO

(A)

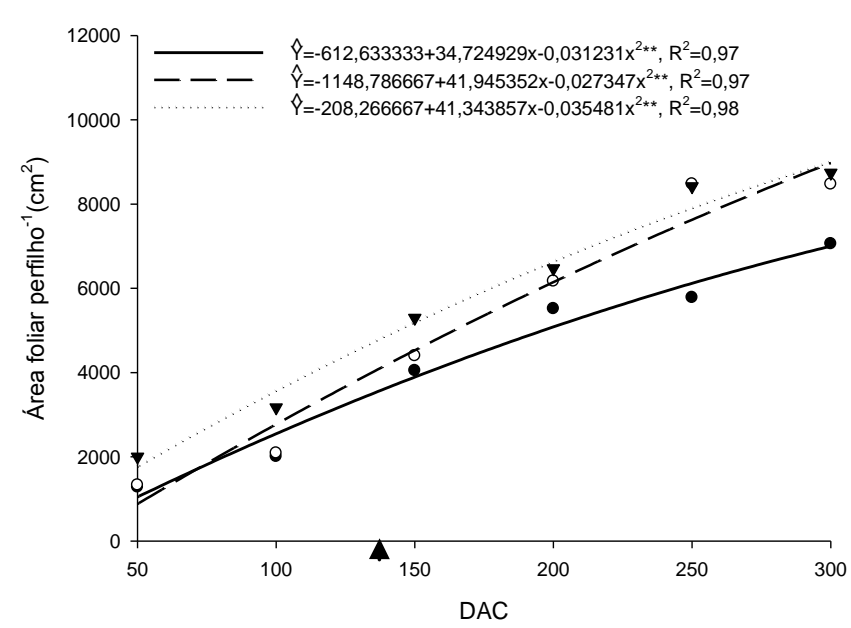

(C)

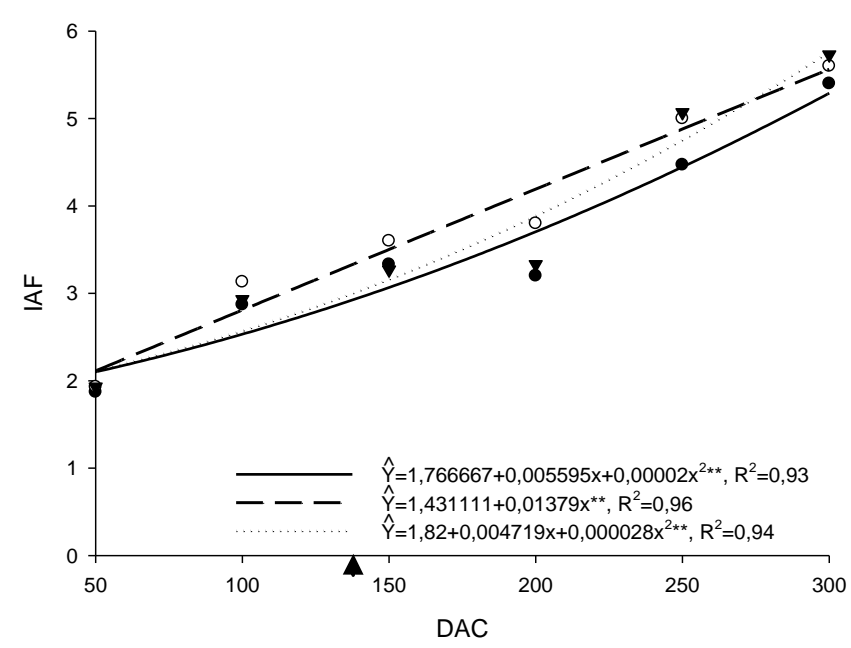

SEQUEIRO

(B)

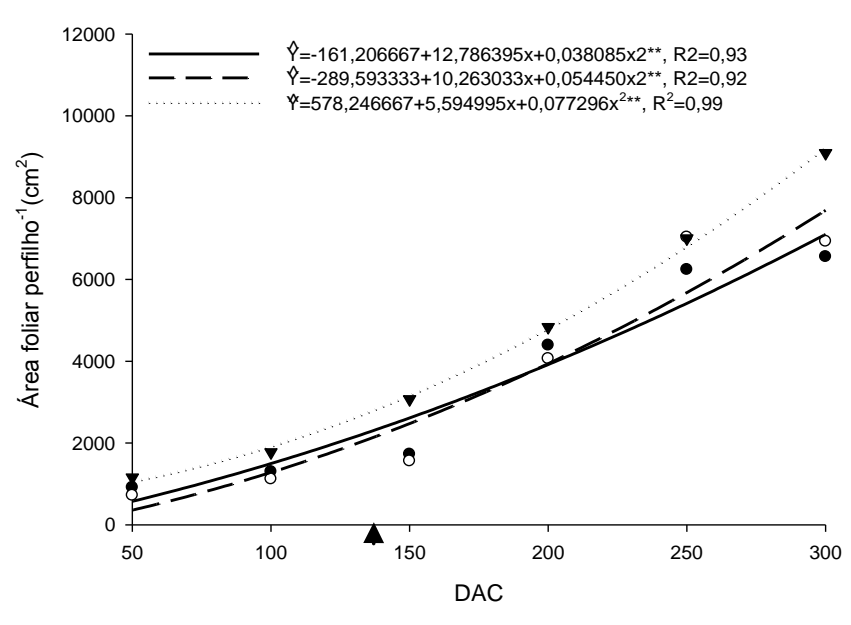

(D)

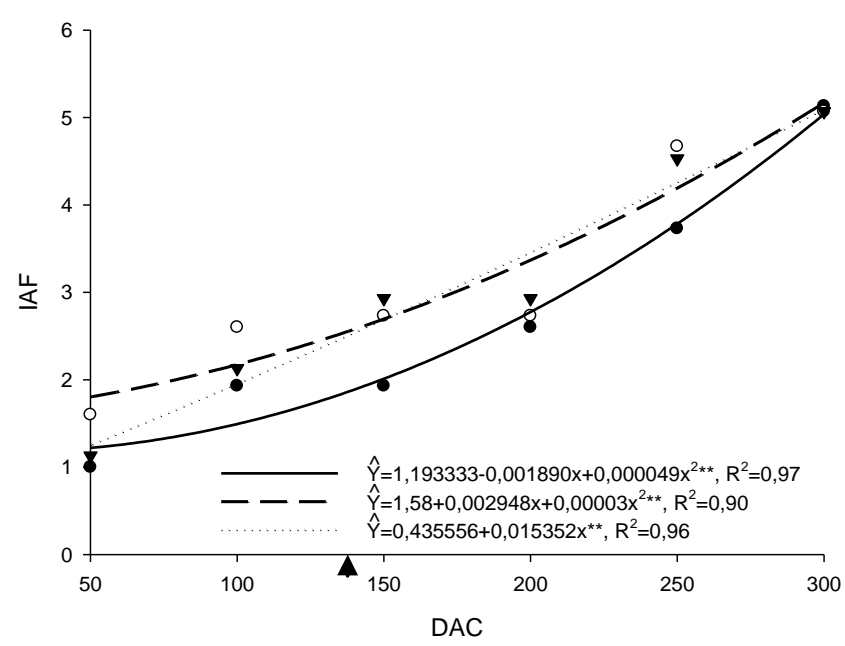

Figura 6. Área foliar $\left(\mathrm{AF}_{\mathrm{c}}\right)$ e índice de área foliar (IAF) dos perfilhos das variedades RB835486 (- •), RB855156 (-----০) e RB867515 (...... $)$ ) de cana-de-açúcar, cultivadas em sistema irrigado e em sequeiro, em função dos dias após o corte (DAC). Embrapa Cerrados, Planaltina-DF (2013). ( $\mathbf{\Delta}$ ) - início do período chuvoso.

As variedades cultivadas sob irrigação RB867515, RB855156 e RB835486 aos 300 DAC apresentaram IAF de 5,73; 5,60 e 5,40, respectivamente, ocorrendo redução de 11,69; 9,46 e $5,0 \%$ quando cultivadas em sequeiro. Foi observado que a variedade RB835486, mesmo tendo redução de apenas 5,0\% no cultivo sob restrição hídrica, continuou apresentando o menor valor de IAF. Verificou-se que no início do estresse hídrico durante o ciclo da cultura, houve redução no NFVA e as dimensões das folhas do perfilho para todas as variedades (Figuras 4 e 5), promovendo a redução da $\mathrm{AF}_{\mathrm{c}}$ e do IAF (área de captação de luz solar), respectivamente. Em conseqüência ocorre a redução da demanda de água pela cultura e diminuição da perda de água por transpiração e das atividades metabólicas de manutenção dos tecidos (INMAN-BAMBER, 2004; INMANBAMBER; SMITH, 2005; SMIT; SINGELS, 2006; INMAM-BAMBER et al., 2008; MACHADO 
et al., 2009). Porém, como já mencionado, as plantas de cana-de-açúcar retornam ao seu desenvolvimento normal, logo após o suprimento de água normalize ao exigido pela cultura (INMAN-BAMBER, 2004). Este é um dos motivos para que essa característica biométrica seja utilizada como um dos principais indicadores do efeito do estresse hídrico em cultivos da cana-deaçúcar (INMAM-BAMBER, 2004).

Os valores do IAF foram superiores aos observados por Costa et al. (2011), ao estudarem crescimento e produtividade de quatro variedades de cana-de-açúcar no quarto ciclo de cultivo, onde observaram que no período da colheita, a variedade RB93509 atingiu o máximo de 4,2, seguida da SP79-1011 com 3,4; da RB92579 com 2,7 e da RB931530 com 2,5. Resultados semelhantes ao IAF do presente trabalho foram observados por Silva et al. (2012) ao testarem variedades de cana-de-açúcar em sistemas de sequeiro e irrigado, onde os autores também relataram o bom desempenho da RB867515, onde observaram IAF aparentemente reduzido no início do ciclo e recuperação até o ponto de corte. Segundo Pereira e Machado (1986), os valores observados de IAF são considerados satisfatórios, pois valores próximos a 4,0 a planta já seria capaz de interceptar 95\% da radiação incidente. Para a RB835486, Shigaki et al.(2004) observaram que esta variedade obteve valores inferiores nos parâmetros de crescimento quando comparadas a outras variedades de cana-de-açúcar cultivas sob estresse hídrico.

Da mesma forma, Silva et al. (2012) e Ecco et al. (2014) observaram que para todas as variáveis biométricas testadas nos tratamentos em sequeiro, as tendências dos resultados foram semelhantes, havendo redução dos valores biométricos no início do desenvolvimento vegetativo da cultura quando cultivadas sob déficit hídrico. No entanto, os autores afirmaram que os perfilhos retomaram o crescimento no início do período chuvoso na região juntamente com a elevação das temperaturas, que ocorreu por volta dos 137 DAC (Figura 1), normalmente se recuperando até o fim do ciclo, semelhante ao ocorrido na presente pesquisa.

De maneira geral, a variedade RB867515 foi a que obteve os maiores valores dos dados biométricos avaliados entre as variedades testadas, e apresentou maior produtividade atingindo produtividade $131,43 \%$ acima da média nacional de 73,6 $\mathrm{Mg} \mathrm{ha}^{-1}$ (CONAB (2014), independente do regime hídrico de empregado no cultivo (sequeiro ou irrigado), porém não diferenciando estatisticamente da variedade RB855156 (Figura 7). 


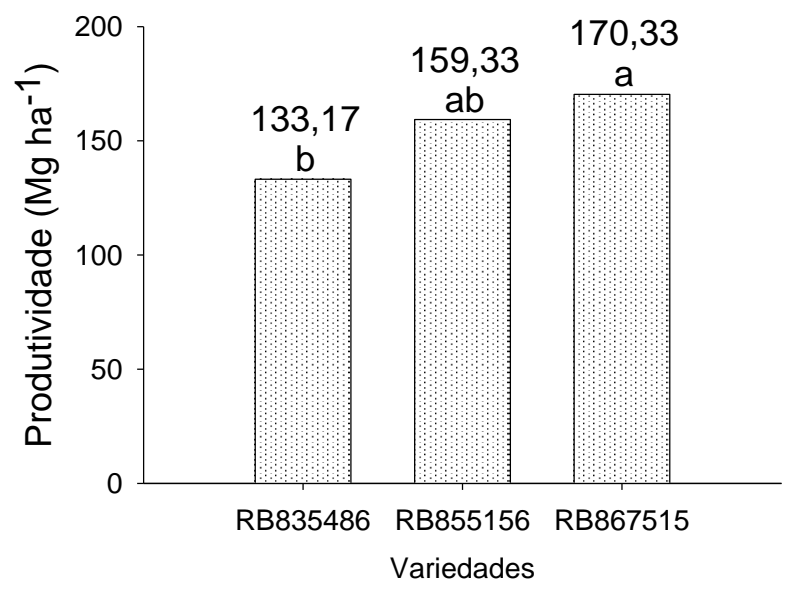

Figura 7. Produtividade das variedades RB835486, RB855156 e RB867515 de cana-de-açúcar cultivadas sob regimes hídricos variáveis.

Mesmo havendo redução das variáveis biométricas para as variedades testadas, estas apresentaram produtividade satisfatória para o quarto ciclo de cultivo, onde naturalmente existe a tendência de declínio do potencial produtivo dos genótipos (COSTA et al. ,2011), o que reforçam ainda mais que, mesmo com o declínio natural do ciclo, as variedades avaliadas, com exceção da RB835486, apresentam boa adaptabilidade às condições climáticas da Região Centro-Oeste do Brasil, assim como o potencial da região para o setor sucroalcooleiro no País.

Os dados biométricos além de serem utilizados na seleção de genótipos no processo de melhoramento genético, também abastecem bancos de dados para modelagens, que permitem fazer estimativas de produtividade de culturas como a cana-de-açúcar (CARLIN, 2008). Essas alterações são expressões gênicas de tolerância e podem variar de acordo com a resposta da variedade de canade-açúcar plantada (IANMAN-BAMBER; SMITH, 2005; TAIZ; ZEIGER, 2013), auxiliando no processo de caracterização e melhoramento vegetal das variedades cultivadas (PUGNAYRE et al., 1993; OLIVEIRA et al., 2007), na capacidade produtiva das mesmas ou na coleta de dados para trabalhos de modelagem de crescimento da cultura em resposta aos diferentes ambientes e sistemas de produção em regiões onde ocorre a estacionalidade das chuvas e uma menor disponibilidade de água para utilização da irrigação (IANMAN-BAMBER; SMITH, 2005; OLIVEIRA et al., 2007). 


\subsection{CONCLUSÕES}

A variedade RB867515 foi a que apresentou maiores valores biométricos de diâmetro médio do colmo, altura média do perfilho, comprimento e largura da folha +3 , tanto em cultivo irrigado como em sequeiro.

Houve redução nos números de numero de folhas verdes completamente abertas (NFVA), e aumento do numero de folhas emergentes (NFE) e o número de folhas mortas (NFM) por perfilhos quando as variedades foram cultivadas em sequeiro.

A variedade RB867515 foi a que apresentou maior produtividade, não diferenciando estatisticamente da RB855156.

Não houve diferença significativa na produtividade para os diferentes regimes hídricos (sequeiro e irrigado). 


\subsection{REFERÊNCIAS BIBLIOGRÁFICAS}

ALMEIDA, A. C. S.; SOUZA, L. J.; TEODORO, I.; BARBOSA, G. V. S.; MOURA FILHO, G.; FERREIRA JÚNIOR, R. A. Desenvolvimento vegetativo e produção de variedades de cana-deaçúcar em relação a disponibilidade hídrica e unidades térmicas. Ciência e Agrotecnologia, Lavras, v.32, n.5, p.1441-1448, 2008.

BENINCASA, M. M. P. Análise de crescimento de plantas: noções básicas. Jaboticabal: FUNEP, 1988. 42p.

BEZERRA, A. R. G.; VIANA, S. B. A. SILVA, M. A. V.; MOSCON, E. S.; PINHEIRO, A. C. T. Avaliação do manejo da irrigação na cultura do algodão. Revista Sodebras, Lorena, v.8, n.85, p.4043, 2013.

BRASIL, Ministério da Agricultura. Levantamento exploratório e conhecimento de solos do Estado da Paraíba. Rio de Janeiro: MA/CONTAP/USAIDSUDENE, 1972. 670p. (Boletim Técnico. 15).

CAMARGO, M. S.; VITTI, A. C. Produção de palhada e colmos de variedades de cana-de-açúcar. Pesquisa \& Tecnologia, São Paulo, v. 11, n. 1, p.1-5, 2014.

CARLIN, S. D.; SILVA, M. A.; ROSSETTO, R. Parâmetros biométricos e produtividade da canade-açúcar após tombamento dos colmos. Bragantia, Campinas, v.67, n.4, p.845-853, 2008.

CASAGRANDE, A. A. Tópicos de morfologia e fisiologia da cana-de-açúcar. Jaboticabal: FUNEP, 1991, 157p.

CONAB, Companhia Nacional de Abastecimento. Acompanhamento de safra brasileira: canade-açúcar, v.1-Safra 2014/2015, n.1- Primeiro levantamento, abri1/2014. Brasília:Conab,2014. 20 p.

COSTA, C. T. S.; FERREIRA, V. M.; ENDRES, L.; FERREIRA, D. T. R. G.; GONÇALVES, E. R. Crescimento e produtividade de quatro variedades de cana-de-açúcar no quarto ciclo de cultivo. Revista Caatinga, Mossoró, v. 24, n.3, p. 56-63, 2011.

DILLEWIJN, C.V. Botany of sugarcane. Waltham: Chronica Botânica, 1952, 371 p.

ECCO, M.; SANTIAGO, E. F.; LIMA, P. R. Respostas biométricas em plantas jovens de cana-deaçúcar submetidas ao estresse hídrico e ao alumínio. Comunicata Scientiae, Bom Jesus, v.5, n.1, p.59-67, 2014.

EMBRAPA. Sistema brasileiro de classificação dos solos. Rio de Janeiro: Embrapa Solos, 2006. $306 \mathrm{p}$.

FERREIRA, D. F. Sisvar: a computer statistical analysis system. Ciência e Agrotecnologia, Lavras, v. 35, n.6, p. 1039-1042, 2011.

HANKS, R. J.; RASMUSSEN, V. P.; WILSON, G. D. Line-source sprinkler for continuous variable irrigation crop production studies. Soil Science Society of America Journal. Madison, v. 40, p. 426-429, 1976.

HERMANN, E. R.; CÂMARA, G. M. S. Um método simples para estimar a área foliar de cana-deaçúcar. Revista Stab, Piracicaba, v. 17, p. 32-34, 1999. 
IDO, O. T.; Desenvolvimento radicular e caulinar, de três variedades de cana-de-açúcar, em Rizotron, em dois substratos. 2003. 141f. Tese (Doutorado em Agronomia) - Universidade Federal do Paraná, Curitiba, 2003.

INMAN-BAMBER, N. G. Sugarcane water stress criteria for irrigation and drying off. Field Crops Research, Amsterdam, v.89, n.1, p.107-122, 2004.

INMAN-BAMBER, N. G.; BONNETT, G. D.; SPILLMAN, M. F.; HEWITT, M. L.; JACKSON, J. Increasing sucrose accumulation in sugarcane by manipulating leaf extension and photosynthesis with irrigation. Australian Journal of Agricultural Research, Melbourne, v.59, p.13-26, 2008.

INMAN-BAMBER, N. G.; SMITH, D. M. Water relations in sugarcane and response to water defi cits. Field Crops Research, Amsterdam, v.92, n.2-3, p.185-202, 2005.

LEME, E. J. A.; MANIERO, M. A.; GUIDOLIN, J. C. Estimativa da área foliar da cana-de-açúcar e sua relação com a produtividade. Cadernos Planalsucar, v.2, v.1, p.3-22, 1984.

MACHADO, R. S.; RIBEIRO, R. V.; MARCHIORI, P. E. R.; MACHADO, D. F. S. P.; MACHADO, E. C.; LANDELL, M. G. A. Respostas biométricas e fisiológicas ao deficit hídrico em cana-de-açúcar em diferentes fases fenológicas. Pesquisa Agropecuária Brasileira. Brasília, v.44, n.12, p. 1575-1582, dez. 2009.

MATIOLI, C.S.; FRIZZONE, J.A.; PERES, F.C. Irrigação suplementar da cana-de-açúcar: modelo de análise de decisão para a região norte do Estado de São Paulo. Stab - Açúcar, Álcool e Subprodutos, Piracicaba, v.17, n.2, p.42-45, 1998.

MONTEITH, J. L. Evaporation and Environment. 19th Symposia of the Society for Experimental Biology, University Press, Cambridge, v. 19, p.205-234, 1965.

OLIVEIRA, R. A.; DAROS, E.; ZAMBON, J. L. C.; WEBER, H.; IDO, O. T.; BESPALHOKFILHO, J. C.; ZUFFELLATO-RIBAS, K. C.; SILVA, D. K. T. Área foliar em três cultivares de cana-de-açúcar e sua correlação com a produção de biomassa. Pesquisa Agropecuária Tropical, Goiânia, v.37, n.2, p.71-76, 2007.

PASSIOURA, J. B. Drought and drought tolerance. In: BELHASSEN, E. (Ed.). Drought tolerance in higher plants: genetical, physiological and molecular biological analysis. Dordrecht: Kluwer, 1997. p.1-5.

PEIXOTO, P. H. O.; PIMENTA, D. L.; CAMBRAIA, J. Alterações morfológicas e acúmulo de compostos fenólicos em plantas de sorgo sob estresse de alumínio. Bragantia, Campinas, v.66, v.1, p.17-25, 2007.

PEREIRA, A. R.; MACHADO, E. C. Um simulador dinâmico do crescimento de uma cultura de cana-de-açúcar. Bragantia, Campinas, v.45, n.1, p.107-122, 1986.

PUGNAIRE, F. I.; ENDOLZ, L. S.; PARDOS, J. Constraints by water stress on plant growth. In: PESSARAKLI, M. (Ed.). Handbook of plant and crop stress. New York: Dekker, 1994. p. 247259.

RAMESH, P. Effect of different levels of drought during the formative phase on growth parameters and its relationship with dry matter accumulation in sugarcane. Journal of Agronomy and Crop Science, v.185, n.1, p.83-89, 2000. 
SANO. S. M.; ALMEIDA, S. P.; RIBEIRO, J. F. Cerrado: ecologia e flora. Brasília: Embrapa Informação Tecnológica, 2008. 1279 p. 2v.

SHIGAKI, F.; FREITAS, N.; BERTO, A.; CEDDIA, M. B.; ZONTA, E.; LIMA, E. Influência do estresse hídrico nos parâmetros de crescimento, acúmulo de $\mathrm{N}$ e produtividade de diferentes variedades de cana-de-açúcar em Miracema - RJ. Revista Universitária Rural-Série Ciências da Vida, v. 24, n. 1, p. 63-71, 2004.

SILVA, T. G. F.; MOURA, M. S. B.; ZOLNIER, S.; CARMO, J. F. A.; SOUZA,L. S. B. Biometria da parte aérea da cana soca irrigada no Submédio do Vale do São Francisco. Revista Ciência Agronômica, Fortaleza, v.43, n.3, p.500-5009, 2012.

SMIT, M. A.; SINGELS, A. The response of sugarcane canopy development to water stress. Field Crops Research, Amsterdam, v.98, p.91-97, 2006.

SMITH, M. Report on the expert consultation on revision of FAO methodologies for crop water requiremebts. Rome: FAO, 1991. 45p.

TAIZ, L.; ZEIGER, E. Fisiologia vegetal. 5 ed. Porto Alegre: Artmed, 2013. 918p. 
CAPítulo II

PRODUTIVIDADE AGRÍCOLA E QUALIDADE INDUSTRIAL DE VARIEDADES DE CANA-DE-AÇÚCAR DE TERCEIRA SOCA SOB REGIME HÍDRICO VARIÁVEL 


\section{CAPÍTULO II - PRODUTIVIDAdE AGRÍCOLA E QUALIDADE INDUSTRIAL DE VARIEDADES DE CANA-DE-AÇÚCAR DE TERCEIRA SOCA SOB REGIME HÍDRICO VARIÁVEL}

\subsection{RESUMO}

O Brasil é o maior produtor mundial de cana-de-açúcar, porém seu atual desafio é a melhoria na produtividade. O presente trabalho teve como objetivo determinar a produtividade agrícola e a qualidade tecnológica do caldo das variedades da cana-de-açúcar, submetidas a diferentes regimes hídricos. O delineamento experimental foi em blocos ao acaso com três repetições em parcelas subdivididas, com três variedades RB855156, RB835486 e RB867515 (parcela), e sete regimes hídricos correspondendo a 0, 7, 17, 36, 46, 75 e 100\% da ETc (subparcela). A irrigação foi aplicada conforme o sistema Line Source Sprinkler System modificado, de forma que a lâmina de água aplicada no tratamento irrigado foi equivalente a $100 \%$ da ETc no centro da área, decrescendo para as extremidades até chegar ao cultivo em sequeiro ( $0 \%$ da ETc), que recebeu somente uma irrigação de salvamento logo após o corte da cana-de-açúcar. Foram avaliados as características de produção: comprimento do entrenó (CE), peso do colmo (PC), número de perfilhos por hectare e produtividade; e tecnológicos do caldo: ${ }^{\circ}$ Brix do caldo, Pol do caldo (Teor de sacarose), pureza (PZA), AR (teor de açúcares redutores do caldo), ARC (açúcares redutores da cana), fibras, Pol da cana (PCC), açúcares totais recuperáveis (ATR) e o valor da megagrama da cana (VMgC). Os dados foram submetidos à análise de variância e regressão e as médias comparadas pelo teste de Tukey a p<0,05. O máximo de produtividade da cana-de-açúcar foi de 182,31 $\mathrm{Mg} \mathrm{ha}^{-1}$ registrado com irrigação equivalente a 69,01\% da ETc; A cana-de-açúcar cultivada com irrigação equivalente a $75 \%$ da ETc não proporcionou diferença significativa para a qualidade industrial das variedades RB835486, RB855156 e RB867515 em relação ao cultivo em sequeiro (0\% da ETc). Não houve diferença significativa para os valores do teor de açúcares redutores (AR), açúcares redutores da cana (ARC) e a pureza do caldo (PZA) entre as variedades RB835486, RB855156 e RB867515.

Palavras-chave: Saccharum spp., estresse hídrico, produção, níveis de irrigação. 


\section{AGRICULTURAL PRODUCTIVITY AND INDUSTRIAL QUALITY OF THIRD RATOON SUGARCANE VARIETIES UNDER ARRANGEMENTS WATER SYSTEM VARIABLE}

\subsection{ABSTRACT}

Brazil is the largest producer of sugarcane, but its current challenge is to improve productivity. This study aimed to determine productivity and the quality industrial of technological quality of juice of the sugarcane varieties under different water regimes. The experimental design was a randomized block with three replications in parcels subdivided with three variety: RB855156, RB835486 e RB867515 (plots), and seven water regimes corresponding to 0, 7, 17, 36, 46, 75 and 100\% Etc (subplots). Irrigation was applied according to the Line Source Sprinkler System so that the amount of water applied to irrigation treatment was equivalent to $100 \%$ of ETc in the center area and decreasing to the ends until reach the cultivation in rainfed ( $0 \%$ of ETc) which had received rescue irrigation immediately after cutting and completely stopping the water supply. The production characteristics were evaluated: length of internode (CE), stem weight (PC), tiller number per hectare and productivity; and technological of the juice: Brix of the juice, the juice Pol (sucrose levels), purity (PZA), RS (content of reducing sugars of the juice), RSC (reducing sugars of cane), fibers, Pol cane (PCC), total recoverable sugars (TRA and the value of megagram sugarcane (VMgC). Data were subjected to analysis of variance and regression and means compared by Tukey test at $\mathrm{p}<0.05$. The maximum productivity of sugar cane was $182.31 \mathrm{Mg} \mathrm{ha}^{-1}$ recorded with irrigation equivalent to $69.01 \%$ of ETc; The sugarcane grown with irrigation equivalent to $75 \%$ of ETc had no significant difference to the quality of industrial RB835486 varieties, RB855156 and RB867515 concerning cultivation in rainfed $(0 \% \mathrm{ETc})$; there was no significant difference in the values of reducing sugars (RS), reducing sugars of cane (RSC) and the juice purity (PZA) among RB835486 varieties, RB855156 and RB867515.

Key Words: Saccharum spp., water stress, yield, levels of irrigation 


\subsection{INTRODUÇÃO}

A cana-de-açúcar (Saccharum spp. L.) é uma cultura que tem se destacado no Brasil pela sua grande importância econômica, social e ambiental; o pais, atualmente, é o maior produtor mundial e responsável por 35\% da produção mundial, seguido da Índia e Austrália (COSTA et al., 2011). Esta cultura tem sido plantada no Brasil desde o século XVI e o seu cultivo pode ser atribuído à sua elevada capacidade de adaptação aos diversos ambientes edafoclimáticos (CORREIA et al., 2014). Atualmente, a sua importância é em função de grandes áreas plantadas e da geração de matéria prima para as agroindústrias do açúcar, álcool e subprodutos. É uma fonte de energia renovável relevante quanto à questão de sustentabilidade ambiental, geração de empregos e renda no meio rural brasileiro (BRASIL, 2006; COSTA et al., 2011).

A importância da cana-de-açúcar no cenário mundial atual provocou a expansão na área plantada pela cultura no Brasil, fato este que foi estimulado pelo aumento das exportações da matéria prima e, principalmente, pela crescente participação dos veículos da frota automotiva brasileira, que utilizam o etanol como combustível é menos poluente e pode ser uma alternativa para o uso de combustíveis fósseis (MAULE et al., 2001).

O Brasil produziu aproximadamente 671,7 milhões de toneladas de cana-de-açúcar na safra 2014/15, representando um aumento de $2 \%$ em relação à safra anterior, tendo uma produtividade média de 73,6 $\mathrm{Mg} \mathrm{ha}^{-1}$, em uma área de aproximadamente 8,735 milhões de ha, e a cultura está em constante expansão, principalmente na Região Centro-Oeste do País, onde o Cerrado é o bioma predominante (CONAB, 2014).

Porém, apesar do Brasil ser o maior produtor mundial de cana-de-açúcar, a sua produtividade ainda está aquém do potencial produtivo da cultura (CONAB, 2014). A cultura é plantada em áreas que em sua maioria possuem precipitação em torno de 1.100 a $1.500 \mathrm{~mm}^{\text {ano }}{ }^{-1}$ (FARIAS et al., 2009), que é considerado insuficiente para que a cultura expresse seu potencial genético de produção (DANTAS NETO et a., 2006). As variedades de cana-de-açúcar cultivada em áreas irrigadas, podem produzir entre 100 e $150 \mathrm{Mg} \mathrm{ha}^{-1}$, representando mais que o dobro da produtividade média do País (GAVA et al., 2011). Por isso, para um melhor rendimento da produção canavieira em algumas regiões agrícolas do Brasil, se faz necessário o uso de irrigação com lâminas adequadas, assim como o uso de variedades reconhecidamente adaptadas para as condições climáticas de cada região do país (DANTAS NETO et a., 2006; CARLIN et al., 2008; FARIAS et al., 2009; CARVALHO et al., 2009).

Moura et al. (2014) afirmaram que a cana irrigada pode apresentar melhor qualidade industrial, com maiores valores nos parâmetros tecnológicos como o ${ }^{\circ}$ Brix, o que pode favorecer uma maturação mais precoce. Os mesmos autores afirmaram que o fornecimento adequado de água durante o ciclo da cultura pode aumentar a sua produtividade e ATR com lâminas equivalentes a 
75\% da capacidade de campo (FARIAS et al., 2009). Por outro lado, a baixa disponibilidade hídrica afeta negativamente o crescimento dos cultivos agrícolas e é a principal causa da redução da produtividade (FLEXAS et al., 2006). Este fato deve ser melhor estudado, pois sabe-se que estresses como a deficiência hídrica podem afetar severamente a produtividade agrícola nas lavouras, principalmente em um País com grandes extensões territoriais como é o caso do Brasil, com variações climáticas consideráveis entre as regiões agricultáveis, além de ser frequente um período de estiagem durante o ciclo da cultura (SILVA et al., 2014a).

A produção de cana-de-açúcar é diretamente dependente da tonelagem da cana, do teor de açúcar e também de sua qualidade industrial (DOORENBOS; KASSAN, 1994). A produtividade nos canaviais e a qualidade industrial da matéria prima no cultivo da cana-de-açúcar é definida como o conjunto de características tecnológicas mínimas que são de acordo com as exigências da indústria para o seu posterior processamento industrial, e tendo como uma de suas principais características o teor de sacarose (MOURA et al., 2005). Estas são atualmente as principais preocupações do setor sucroalcooleiro no Brasil, a fim de se obter um produto economicamente competitivo. A concentração de açúcares tem a sua destacada importância, pois a partir destes são obtidos os demais subprodutos da cana-de-açúcar. O teor de açúcares é responsável pelo rendimento econômico do cultivo, e pode ser avaliado através de parâmetros tecnológicos como o ${ }^{\circ}$ Brix (teor de sólidos solúveis), Pol (teor de sacarose), PZA (pureza do caldo), fibras e PCC (percentagem de açúcar bruto). A partir desses parâmetros é possível estimar o valor da tonelada da cana produzida e o seu potencial econômico (CORREIA et al., 2014).

A avaliação dos efeitos regimes hídricos sobre os componentes de produção e sua relação com a produtividade pode auxiliar os programas de melhoramento vegetal a selecionar genótipos produtivos sob essa condição (SILVA et. al., 2008). Neste contexto, o presente trabalho teve como objetivo determinar a produtividade agrícola e a qualidade industrial variedades de canade-açúcar submetidas a diferentes níveis de irrigação. 


\subsection{MATERIAL E MÉTODOS}

O experimento foi conduzido em condições de campo entre abril de 2013 e abril de 2014, em uma área de 0,36 hectares, localizada na Embrapa Cerrados (CPAC), situada na BR 020, Km 18 (latitude 15³9'84' 'Sul e longitude 4744'41', Oeste), próxima à Região Administrativa de Planaltina-DF. A altitude da área é de aproximadamente $1014 \mathrm{~m}$ com temperatura e pluviosidade média anual de $21,9^{\circ} \mathrm{C}$ e $1.395,6 \mathrm{~mm}$, respectivamente.

O clima da região é classificado como tropical estacional (Aw), conforme Köppen (BRASIL, 1972), sendo caracterizado por duas estações bem definidas: seca e chuvosa. Podem ocorrer períodos de estiagem (veranicos) durante a estação chuvosa (SANO et al., 2008).

Os dados de precipitação pluviométrica, evapotranspiração de referência (ETo), temperatura máxima $\left({ }^{\circ} \mathrm{C}\right)$, temperatura mínima $\left({ }^{\circ} \mathrm{C}\right)$ e temperatura média durante a condução do experimento estão apresentados na Figura 1.

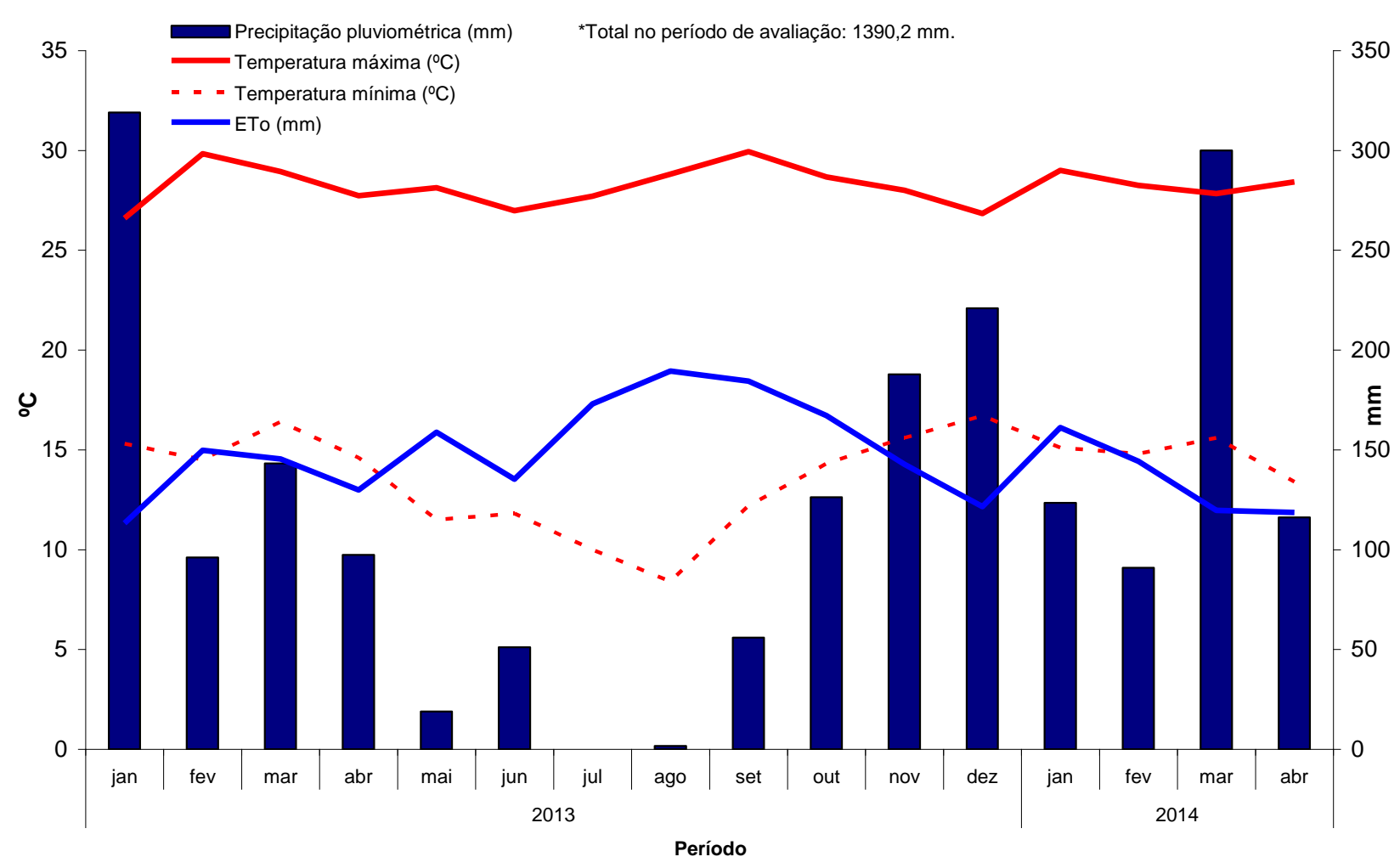

Figura 1. Precipitação pluviométrica, evapotranspiração de referência (ETo), temperatura máxima $\left({ }^{\circ} \mathrm{C}\right)$, temperatura mínima $\left({ }^{\circ} \mathrm{C}\right)$ da Região Administrativa de Planaltina-DF durante $\mathrm{o}$ período de 05/05/2013 a 24/04/2014. Dados coletados na Estação Meteorológica da Embrapa Cerrados, Planaltina-DF (2013).

O solo da área experimental é classificado como um Latossolo Vermelho Distrófico Típico, textura argilosa, A moderado (EMBRAPA, 2006) e sua caracterização química antes da instalação do experimento está apresentada na Tabela 1. 
Tabela 1. Caracterização química do solo da área de cultivo da cana-de-açúcar. Embrapa Cerrados, Planaltina-DF (2013).

\begin{tabular}{|c|c|c|c|c|c|c|c|c|}
\hline $\begin{array}{l}\text { Profundidade } \\
----\mathrm{cm} \text {---- }\end{array}$ & $\mathrm{pH} \mathrm{H} \mathrm{H}_{2} \mathrm{O}$ & $\begin{array}{c}\mathrm{Al} \\
--\mathrm{cmol}_{\mathrm{c}} \mathrm{dm}^{-3}--\end{array}$ & $\begin{array}{c}\mathrm{P} \\
----\mathrm{m}\end{array}$ & $\begin{array}{r}\mathrm{K} \\
\mathrm{n}^{-3}---- \\
\end{array}$ & $\mathrm{Ca}$ & $\begin{aligned} & \mathrm{Mg} \\
&= \mathrm{mol}_{\mathrm{c}} \mathrm{d} \\
&\end{aligned}$ & $\mathrm{H}+\mathrm{Al}$ & $\begin{array}{c}\text { MO } \\
---\%--- \\
\end{array}$ \\
\hline $0-20$ & 5,08 & 0,39 & 0,22 & 8,00 & 0,56 & 0,26 & 3,70 & 0,87 \\
\hline $20-40$ & 5,20 & 0,04 & 0,50 & 16,00 & 1,19 & 0,68 & 3,46 & 1,15 \\
\hline $40-60$ & 5,16 & 0,13 & 0,76 & 32,00 & 0,96 & 0,52 & 3,30 & 1,30 \\
\hline $60-80$ & 5,13 & 0,19 & 0,83 & 22,00 & 1,08 & 0,44 & 3,18 & 1,30 \\
\hline $80-100$ & 5,10 & 0,24 & 0,81 & 30,00 & 0,99 & 0,53 & 3,60 & 1,30 \\
\hline $100-120$ & 5,34 & 0,09 & 0,58 & 18,00 & 1,41 & 0,68 & 2,98 & 0,99 \\
\hline $120-140$ & 5,22 & 0,25 & 0,73 & 18,00 & 0,91 & 0,47 & 3,84 & 1,27 \\
\hline $140-160$ & 5,03 & 0,32 & 0,66 & 12,00 & 0,77 & 0,37 & 3,88 & 0,97 \\
\hline $160-180$ & 5,01 & 0,37 & 0,37 & 12,00 & 0,72 & 0,38 & 3,78 & 1,13 \\
\hline $180-200$ & 5,13 & 0,27 & 0,39 & 4,00 & 0,92 & 0,46 & 3,54 & 0,82 \\
\hline $200-220$ & 5,20 & 0,14 & 0,39 & 4,00 & 0,97 & 0,44 & 3,32 & 1,14 \\
\hline $220-240$ & 5,25 & 0,09 & 0,42 & 8,00 & 1,09 & 0,49 & 3,36 & 0,94 \\
\hline
\end{tabular}

Realizou-se na área, antes do plantio, uma adubação corretiva (a lanço e incorporada) de $500 \mathrm{~kg} \mathrm{ha}^{-1}$ de gesso e $50 \mathrm{~kg} \mathrm{ha}^{-1}$ de FTE BR-10 (pó) como fonte de micronutrientes ( $\mathrm{Zn}, \mathrm{B}, \mathrm{Cu}, \mathrm{Fe}$, Mn e Mo com 7,0, 2,5, 1,0, 4,0, 4,0 e 0,1\% respectivamente). O plantio da cana-de-açúcar foi realizado de forma manual em 18 de junho de 2010 aplicando-se a dose de $600 \mathrm{~kg} \mathrm{ha}^{-1}$ de NPK na formulação 04-30-16. Foram utilizadas três variedades: RB855156, RB835486 ambas de maturação precoce e a RB867515, como variedade de referência por ser a mais cultivada no Brasil (CAMARGO; VITTI, 2014).

A adubação de cobertura foi aplicada de forma manual, após o primeiro corte das plantas e em dois períodos, no início de maio na dose de $400 \mathrm{~kg} \mathrm{ha}^{-1}$ de NPK (formulação 20-00-20) e em novembro de 2011 na dose de $600 \mathrm{~kg} \mathrm{ha}^{-1}$ de NPK (formulação 20-00-24), repetindo-se esta mesma adubação nos anos posteriores.

Após o primeiro corte, realizado em maio de 2011, que corresponde à chamada canaplanta, o canavial foi colhido mais três vezes (cana soca) a partir da rebrota da cana cortada (soqueira). Aproximadamente de 20 a 30 dias após cada corte, realizou-se uma irrigação de salvamento com uma lâmina de água de aproximadamente $60 \mathrm{~mm}$ devido à baixa precipitação neste período. Em seguida as três variedades de cana (RB855156, RB835486 e RB867515) foram submetidas a diferentes regimes hídricos.

O manejo da irrigação foi realizado com base na metodologia Penman-Monteith (MONTEITH, 1965), recomendado pela FAO (SMITH, 1991), e nos dados climatológicos, coletados nos meses de janeiro de 2013 a abril de 2014 na estação meteorológica localizada a 100m do experimento. $\mathrm{Na}$ área experimental, a irrigação foi realizada conforme o sistema Line Source Sprinkler System, descrito por Hanks et al. (1976), e modificado para aplicação na forma de barras 
lineares acopladas a um carretel (Figura 2), em que a lâmina de água aplicada na cultura descresse do centro para as extremidades da área.

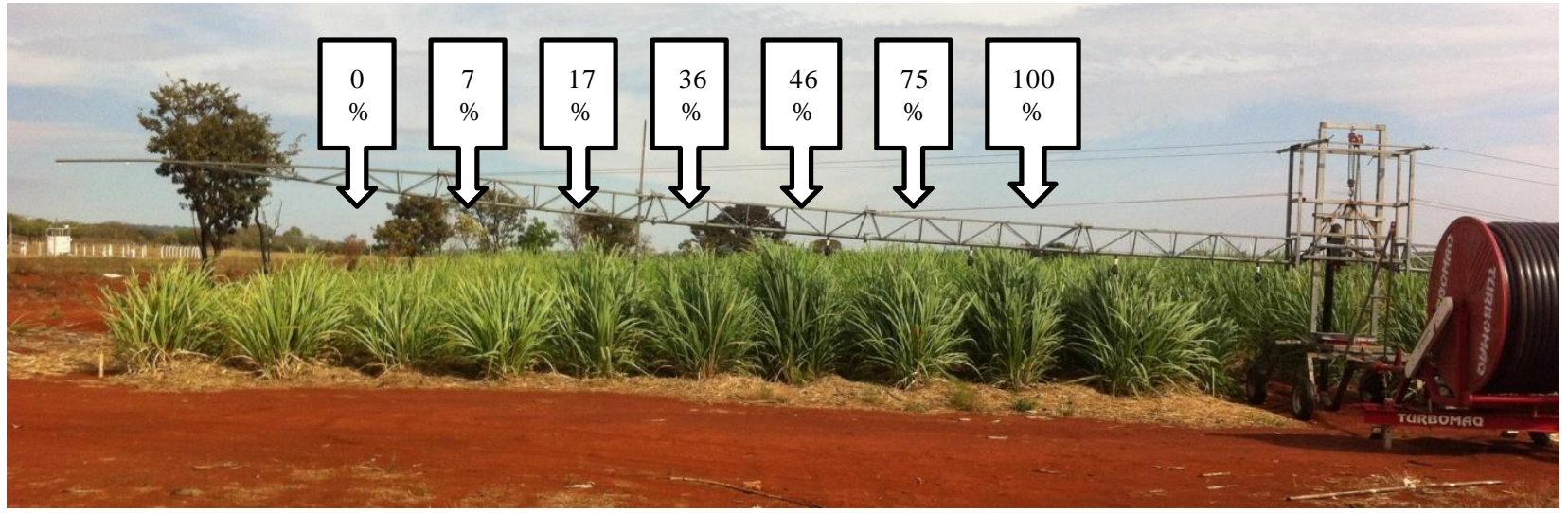

Figura 2. Sistema Line Source Sprinkler System, mostrando as parcelas experimentais: 0, 7, 17, 36, 46, 75 e 100\% da ETc. Embrapa Cerrados, Planaltina-DF (2013).

O experimento foi conduzido no delineamento de blocos ao acaso com três repetições em parcelas subdivididas, três variedades (parcelas) e sete níveis de irrigação (subparcelas). Cada parcela foi composta por uma fileira de plantas com 4,0 m de comprimento e 1,5 m de largura, sendo a área útil formada pelos 3,0 m centrais da mesma, descartando-se 0,5 $\mathrm{m}$ de cada lado para evitar o efeito da bordadura.

As parcelas foram irrigadas em turno de rega fixo com intervalos de 9 dias e receberam sete lâminas de irrigação que corresponderam a 0,7, 17, 36, 46, 75 e 100\% da evapotranspiração da cultura (ETc), estimada através do balanço climatológico, utilizando-se a irrigação via sistema autopropelido com barra irrigadora com bocais conjugados e emissores XI-Wobbler (Figura 2).

Para o tratamento correspondente a $0 \%$ da ETc, o suprimento hídrico foi completamente suspenso após a irrigação de salvamento, na tentativa de reproduzir a realidade dos sistemas de produção de algumas usinas da região Centro-Oeste, que tem canaviais implantados em áreas sob longos períodos de deficiência hídrica devido à estacionalidade pluviométrica.

A colheita do experimento no quarto corte da cana-de-açúcar foi realizada de forma manual, iniciando no dia 04 de abril de 2014, aos 335 dias após o corte (DAC). Os colmos da área útil da parcela foram colhidos, despalhados, contados e pesados para a determinação da produtividade e o peso médio dos colmos, que foi expresso em megagrama de colmos por hectare $\left(\mathrm{Mg} \mathrm{ha}^{-1}\right)$ e quilograma $(\mathrm{kg})$ respectivamente. Para a pesagem dos colmos, utilizou-se uma balança Kern HCB Modelo 99K50. Foram quantificados, ainda, o comprimento médio dos entrenós (CE), utilizando uma trena graduada e o número de perfilhos por hectare.

Durante a colheita do experimento, sete colmos de cada tratamento foram amostrados de forma aleatória, correspondendo à subparcela sem irrigação $(0 \%$ da ETc) e da subparcela de irrigação que atingiu a máxima produção entre os níveis de irrigação para comparação entre os dois 
(75\% da ETc). As amostras foram encaminhadas ao laboratório da Usina Jalles Machado (Goianésia - GO) e as análises dos índices tecnológicos foram realizadas num período inferior a 36 horas após a colheita.

Foram avaliados os seguintes parâmetros: ${ }^{\circ}$ Brix do caldo, Pol do caldo, pureza (PZA), AR (teor de açúcares redutores do caldo), ARC (açúcares redutores da cana), fibras da cana, Pol da cana (PCC), açúcares totais recuperáveis (ATR) e o valor da megagrama da cana (VMgC), conforme CONSECANA (2006).

$\mathrm{O}{ }^{\circ}$ Brix é expresso em porcentagem de sólidos solúveis por peso de caldo da cana-deaçúcar. A determinação do ${ }^{\circ}$ Brix foi realizada utilizando-se refratômetro digital, de leitura automática, com correção automática de temperatura e resolução máxima de $0,1^{\circ}$ Brix (um décimo de grau brix), a $20^{\circ} \mathrm{C}$.

O Pol do caldo representa a porcentagem de sacarose contida numa solução de açúcares (sacarose, glicose e frutose). A leitura sacarimétrica do caldo foi determinada em sacarímetro digital, automático, com peso normal igual a $26 \mathrm{~g}$, resolução de $0,01^{\circ} \mathrm{Z}$ (um centésimo de grau de açúcar) e calibrado a $20^{\circ} \mathrm{C}$, com comprimento de onda de 587 e $589,4 \mathrm{~nm}$, possuindo tubo polarimétrico de fluxo contínuo, após clarificação do caldo com mistura clarificante à base de alumínio.

A pureza do caldo (PZA) é a porcentagem de sacarose contida nos sólidos solúveis do caldo e foi determinada a partir da percentagem de sólidos solúveis totais no caldo extraído, após a determinação do Pol e do ${ }^{\circ}$ Brix (CORREIA et al., 2014). A pureza é determinada pela equação:

$P Z A \%=(P O L \%$ caldo $/$ BRIX\%caldo $) \times 100$

O teor de açúcares redutores do caldo (AR), que é composto por glicose e frutose, oriundos da hidrólise da sacarose, é determinado pela equação:

$A R_{\% \text { caldo }}=3,641-0,0343 \times Q$

Onde: $\mathrm{Q}=$ Pureza do caldo (PZA) (eq.1)

Teor de ARC ou ART é o teor de açúcares redutores contidos na cana-de-açúcar, sendo determinado pela equação:

$A R C_{\% c a n a}=A R \times(1-0,01 \times F) \times C$

Onde: $\mathrm{F}=$ Fibra da cana em \% (eq.4); $\mathrm{C}=$ coeficiente "c" é utilizado para a transformação de Pol do caldo extraído pela prensa em Pol da cana (PCC), e é calculada pela equação: $\mathrm{C}=1,0313-0,00575$ x F.

A partir do Pol do caldo foi determinado o Pol da cana, calculando-se o teor de fibra da cana (\%). A fibra industrial (matéria insolúvel em água contida na cana) foi calculada em função do peso, em gramas, do material fibroso residual de prensagem (bolo úmido de bagaço) e equivale a 
0,1005 desse peso, expresso em porcentagem. O cálculo da fibra da cana é determinado segundo a equação: (CORREIA et al., 2014)

$$
F I B R A=[(100 \times P S) \times(P U \times b)] / 5 \times(100-b)
$$

Onde: $\mathrm{PS}=$ peso do bolo seco a $105{ }^{\circ} \mathrm{C} ; \mathrm{PU}=$ peso do bolo úmido (resíduo fibroso); $\mathrm{b}=$ Brix do caldo extraído.

O Pol da cana ou percentagem de açúcar bruto (PCC) é um índice que está diretamente relacionado ao valor econômico da tonelada da cana, pois determina se a produção tem preços compatíveis no mercado (ASSIS et al., 2004). O PCC é determinado pela equação citada por Assis et al. (2004) e Correia et al. (2014):

Pol da cana $\left(\right.$ ou PCC) $=L_{\text {corr }} \times(1-0,01 \times F) \times C$

Onde: $\mathrm{L}_{\text {corr }}=$ Pol do caldo extraído $(\%)$.

Os açúcares totais recuperáveis (ATR) representam a concentração total de açúcares (sacarose, glicose e frutose) recuperáveis no processo industrial e é expresso em $\mathrm{kg} \mathrm{Mg}^{-1} \mathrm{de}$ cana (SACHS, 2007), e o valor é obtido em função dos preços líquidos do açúcar branco destinado ao mercado interno e externo do açúcar VHP (açúcar bruto, que permite transformá-lo em diferentes tipos de açúcar para o consumo) destinado ao mercado externo, do álcool anidro e hidratado (carburante e industrial) comercializados no mercado doméstico e internacional. É determinado, também, pelo mix de produção de cada unidade industrial, ou seja, a quantidade produzida de açúcar e álcool, e pela participação da matéria-prima nos custos de produção do açúcar e do álcool (CORREIA et al., 2014). O ATR é expresso em quilogramas por tonelada de cana, e determinado conforme a equação:

$$
A T R=9,5263 \times P C C+9,05 \times A R C\left(\text { em } \mathrm{kg} \mathrm{Mg}^{-1} \text { de cana }\right)
$$

Onde: 9,05 representa um coeficiente de recuperação, para uma perda industrial de $9,5 \%$.

O sistema de pagamento da cana utiliza como base a qualidade da cana-de-açúcar expressa em ATR contido em uma tonelada de cana. Um quilo de ATR não equivale exatamente a um quilo de açúcar obtido por meio de cristalização no processo industrial (BURNQUIST, 1999). A equação para determinar o valor do Megagrama de cana $(\mathrm{VMgC})$ é:

$\operatorname{VMgC}\left(R \$ \mathrm{Mg}^{-1}\right)=$ Qde de ATR $\left(\mathrm{kg} \mathrm{Mg}^{-1}\right.$ de cana) $x$ Valor do ATR $\left(R \$ \mathrm{~kg}^{-1}\right.$ de ATR) (7)

Onde: $\mathrm{VMgC}=$ valor-base para a cana, em real por megagrama, colocada na esteira da unidade industrial; ATR = teor de Açúcar Total Recuperável da cana, expresso em $\mathrm{kg} \mathrm{Mg}^{-1} \mathrm{de}$ cana; Valor do ATR = preço médio de um quilo de Açúcar Total Recuperável (ATR), cotado a R \$ 0,4802 para a safra 2014/2015.

Os dados foram submetidos à análise de Normalidade pelo teste Shapiro-Wilk, analisando a significância a 5\%; análise de Homocedase a significância a 5\%, pelo teste de Levene 
para verificar possíveis heterocedasticidade dos erros; e a Independência dos dados pelo teste de Durbin-Watson. Em seguida os dados foram submetidos à análise de variância e regressão polinomial pelo teste $\mathrm{F}$ a $5 \%$ de probabilidade, e as médias comparadas pelo teste Tukey a 5\% de probabilidade. Para as análises estatísticas foi utilizado o software Sisvar (FERREIRA, 2011). 


\subsection{RESULTADOS E DISCUSSÃO}

Houve interação significativa entre as variedades e os regimes hídricos para os valores de comprimento do entrenó (CME). Para o peso do colmo e produtividade foi verificado resultado significativo somente para os efeitos isolados de variedade e lâminas de água (irrigação). No entanto, para o número de perfilhos por hectare, a irrigação não proporcionou diferenças significativas e houve efeito somente das variedades testadas (Tabela 3).

Tabela 3. Resumos das análises de variâncias referentes ao comprimento do entrenó (CME), peso do colmo (PC), o perfilhamento e a produtividade.

\begin{tabular}{lccccc}
\hline \multirow{2}{*}{ FV } & \multirow{2}{*}{ GL } & \multicolumn{3}{c}{ Quadrado médio } \\
\cline { 3 - 6 } & & CME & PC & Perfilhamento & Produtividade \\
\hline Bloco & 2 & $0,63^{\text {ns }}$ & $0,19^{\text {ns }}$ & $240094030,81^{\text {ns }}$ & $223,86^{\text {ns }}$ \\
Variedade (V) & 2 & $58,99^{* *}$ & $2,38^{* *}$ & 237319216 E+0009* & $10028,71^{*}$ \\
Resíduo a & 4 & 1,72 & 0,03 & 132157570,49 & 892,99 \\
Irrigação ( I ) & 6 & $2,82^{* *}$ & $0,66^{* *}$ & $214853973,62^{\text {ns }}$ & $7053,64^{*}$ \\
V x I & 12 & $3,61^{* *}$ & $0,11^{\text {ns }}$ & $206662737,72^{\text {ns }}$ & $441,99^{\mathrm{ns}}$ \\
Resíduo b & 36 & 0,32 & 0,06 & 236083326,35 & 527,79 \\
\hline Média & & 16,27 & 1,68 & 92169,31 & 151,60 \\
\hline CV1 (\%) & & 8,07 & 10,79 & 12,47 & 19,71 \\
CV2 (\%) & 3,52 & 15,16 & 16,67 & 15,15 \\
\hline FV: fon
\end{tabular}

FV: fonte de variação; GL: grau de liberdade; CV: coeficiente de variação; ns: não significativo; * e **: significativo para $\mathrm{p}<0,05$ e $\mathrm{p}<0,01$, respectivamente; CE - comprimento do entrenó $(\mathrm{cm})$; PC - peso do colmo $(\mathrm{kg})$; Perfilhamento (perfilhos ha $\left.{ }^{-1}\right)$; Produtividade $\left(\mathrm{Mg} \mathrm{ha}^{-1}\right)$.

O CME das variedades RB867515 e RB855156 respondeu significativamente em um modelo quadrático para os níveis crescentes de irrigação, aumentando o comprimento do entrenó a medida que aumentou a lâmina de água aplicada, atingindo o valor máximo de 18,09 cm com irrigação, equivalente a 50,67\% da ETc, e a RB855156 com 18,03 cm aos 62,96\% da ETc; a partir do máximo, ambas apresentaram decréscimo nos valores de CE com o aumento dos níveis de irrigação. Para a variedade RB835486 foi registrado maior CME houve redução dos valores à medida que aumentou a quantidade de água aplicada na irrigação (Figura 3).

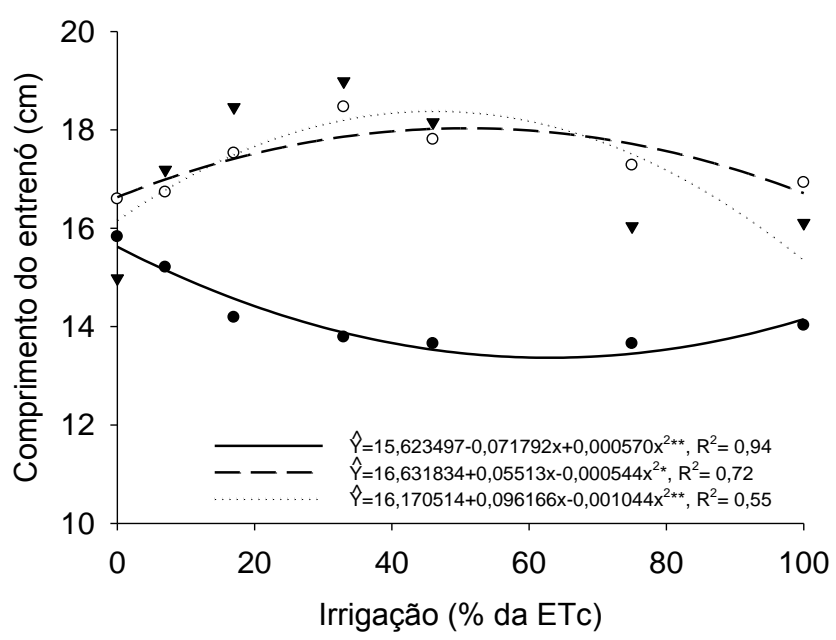

Figura 3. Comprimento do entrenó (CE) de plantas das variedades RB835486 ( — •), RB855156 (-----O) e RB867515 (......v) de cana-de-açúcar em diferentes regimes hídricos. 
O alongamento do entrenó pode ser atribuído à disponibilidade hídrica adequada durante todas as fases do ciclo da cultura, incluindo o período de crescimento da cana-de-açúcar, o que conseqüentemente favorece a disponibilidade de nutrientes para o sistema radicular da planta (OLIVEIRA et al., 2011), seguido da remobilização de energia e transporte de carboidratos e água das raízes, favorecendo assim o aumento e alongamento celular do colmo, o que pode afetar diretamente a produtividade (INMAM-BAMBER; SMITH, 2005; SINGH et al., 2007).

Ramesh e Mahadevaswamy (2000) afirmaram que a condição de restrição hídrica, favorece a redução do comprimento do entrenó na cana-de-açúcar, justificando o que ocorreu com as variedades RB855156 e RB867515 no cultivo em sequeiro (0\% da ETc). No entanto, o efeito contrário que ocorreu com a variedade RB835486, reduzindo o CME com o aumento da quantidade de água, tais resultados podem estar associados à incidência da podridão vermelha, causada pelo agente etiológico Colletotrichum falcatum, sendo verificado que toda a área das parcelas dessa variedade foi afetada pelo fungo. A incidência foi elevada concomitantemente com o aumento do uso da irrigação, e também com o início da estação chuvosa, o que serve como indicativo da sua pouca adaptação desta variedade para a Região Centro-Oeste, pela susceptibilidade a fungos em altitudes elevadas (DAROS et al., 2010). Devido ao ataque do fungo na área foliar das plantas, ocorre uma menor eficiência do processo de fotossíntese, levando a redução da formação e acumulação de açúcares resultando em colmos menores, mais finos e com entrenós curtos, podendo provocar perdas industriais, principalmente pela inversão da sacarose e diminuição da pureza do caldo (GALLO et al., 2002; VISWANATHAN; SAMIYAPPAN, 2002). Adicionalmente, cada genótipo tem uma lâmina ótima em que acima disso pode ocorrer estresse por excesso de água ou ainda acamamento, que também ocorreu em maior ou menor grau nos materiais testados, nas maiores lâminas de água.

Para a produtividade e o peso do colmo (PC), os dados também se ajustaram em um modelo quadrático para o efeito isolado da irrigação, proporcionando aumento da produtividade até atingir o máximo de $182,31 \mathrm{Mg} \mathrm{ha}^{-1}$ com irrigação equivalente a 69,01\% da ETc; e o PC máximo de $1,96 \mathrm{~kg}$ com a reposição de $76 \%$ da ETc (Figura 4B), correspondendo a um incremento de $65,90 \%$ e $49,62 \%$ para a produtividade e PC respectivamente, quando comparado ao cultivo aqui denominada sequeiro, mas que sofreu apenas a irrigação de salvamento (Figura 4). 
(A)

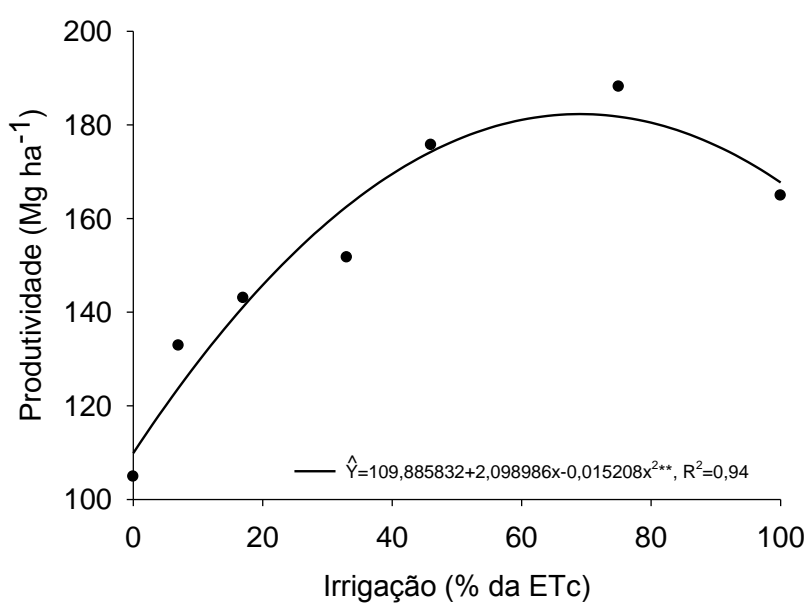

(B)

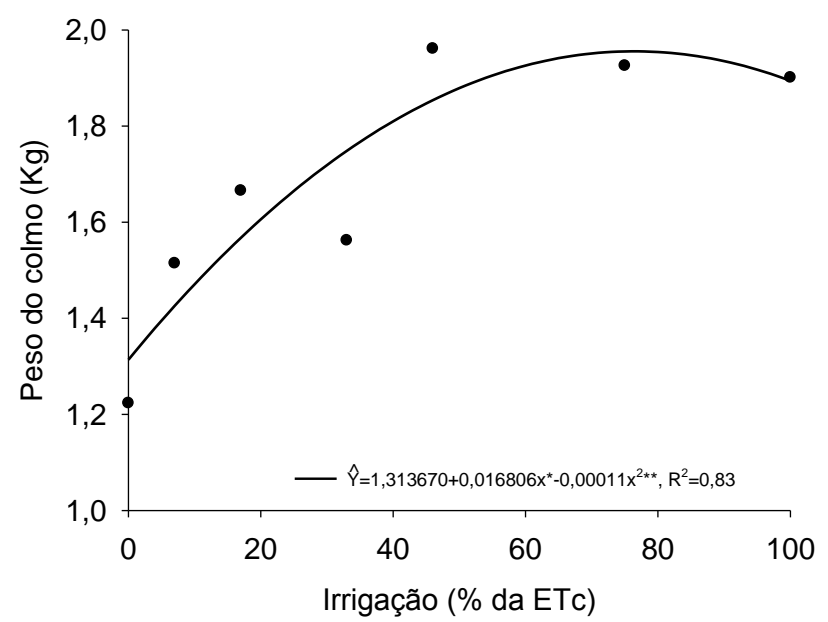

Figura 4. Valores médios da Produtividade (A) e peso do colmo (B) de plantas das variedades RB835486, RB855156 e RB867515 de cana-de-açúcar cultivada sob diferentes regimes hídricos.

Os valores máximos da produtividade obtidos foram $147 \%$ superiores à média nacional de 73,6 $\mathrm{Mg} \mathrm{ha}^{-1}$ para a safra 2013/2014 (CONAB, 2014), com valores acima do rendimento esperado para o cultivo da cana-de-açúcar em sistema irrigado nos trópicos úmidos, que é de 100 a $150 \mathrm{Mg} \mathrm{ha}^{-1}$ (DOORENBOS; KASSAM, 1994; GAVA et al., 2011), com irrigação e corresponde à irrigação de $80 \%$ de água disponível (fração de esgotamento de $20 \%$ ). A produtividade de cana-deaçúcar do presente trabalho também foi superior ao máximo de $127,86 \mathrm{Mg} \mathrm{ha}^{-1}$ para a variedade RB867515 verificado por Silva et al. (2014b), quando estes avaliaram a produtividade de oito variedades cana-de-açúcar em resposta a diferentes níveis de irrigação por dois ciclos (cana-planta e cana-soca) na região de Jaú-SP com 1.480 mm de precipitação média anual (déficit hídrico de 193 $\mathrm{mm}$ ) e em um Latossolo vermelho eutrófico típico.

Para o cultivo em sequeiro, os resultados foram semelhantes aos relatados por Costa et al. (2011) onde obtiveram produtividade de 109,79 $\mathrm{Mg} \mathrm{ha}^{-1}$ para a variedade $\mathrm{RB} 93509$ em regime de sequeiro ao avaliar o crescimento e produtividade de quatro variedades de cana-de-açúcar no quarto ciclo de cultivo (terceira soca) na Região de Rio Largo-AL, que teve precipitação anual de $1.816,8 \mathrm{~mm}$.

Oliveira et al. (2011) observaram valores superiores para o cultivo da variedade RB867515, na condição de cana-planta, e sob irrigação plena (1.396,6 mm), obtendo $186 \mathrm{Mg} \mathrm{ha}^{-1}$, correspondendo a um acréscimo de $112 \%$ na produtividade quando comparado com o cultivo em sequeiro (87,6 $\mathrm{Mg} \mathrm{ha}^{-1}$ ) nas condições climáticas de Carpina-PE (que possui precipitação pluviométrica $1.141,4 \mathrm{~mm}$, sendo inferior a região do presente trabalho e apresentando chuva nos meses de inverno e déficit no meses de verão). Os mesmos autores ainda afirmaram que os genótipos de cana-de-açúcar testados na pesquisa responderam com até $180 \%$ de incremento 
máximo na produtividade quando cultivados com irrigação plena para a variedade SP81-3250 (83,1 para 232,5 $\mathrm{Mg} \mathrm{ha}^{-1}$ ) e um mínimo de $107 \%$ (87,8 para 181,5 $\mathrm{Mg} \mathrm{ha}^{-1}$ ) para a variedade RB863129, comparando os cultivos irrigado e sequeiro, respectivamente.

Os resultados obtidos no presente trabalho também foram superiores aos observados por Gava et al. (2011), com produtividade máxima de 140,9 $\mathrm{Mg} \mathrm{ha}^{-1}$ em cultivo irrigado (1.797 mm), e $115,8 \mathrm{Mg} \mathrm{ha}^{-1}$ no cultivo em sequeiro $(1.437 \mathrm{~mm})$ para a variedade RB867515 por dois ciclos (cana-planta e cana-soca) na região de Jaú-SP, tendo a produtividade reduzida no segundo ciclo (cana-soca) para 118,8 e 84,9 $\mathrm{Mg} \mathrm{ha}^{-1}$ (irrigado e sequeiro, respectivamente), mesmo não possuindo período seco marcante como na área do presente trabalho.

De acordo com Oliveira et al. (2009), o uso da irrigação é tecnicamente viável no cultivo da cana-de-açúcar, podendo atingir incrementos de até $15,39 \%$ a mais que a produtividade em sequeiro. Porém, estes autores obtiveram valores máximo de $101,87 \mathrm{Mg} \mathrm{ha}^{-1} \mathrm{em}_{\text {cultivo irrigado }}$ no terceiro corte, sendo observado decréscimo de $40 \%$ na produtividade do terceiro para o quarto corte, mesmo com o uso da irrigação. Além disso, Vieira et al. (2012) afirmam que a produtividade máxima de colmos para a RB867515 em cana-soca foi de $125,90 \mathrm{Mg} \mathrm{ha}^{-1}$ com aplicação de uma lâmina equivalente a $1.854,4 \mathrm{~mm}$, ocorrendo declínio da produtividade como aumento da lâmina, ambos com produtividades bem inferior ao presente trabalho.

Em cultivos de cana-de-açúcar sob estresse hídrico, a redução dos rendimentos nos canaviais é esperada, haja vista que a ocorrência, intensidade e duração desse tipo de estresse tende a provocar modificações morfofisiológicas de defesa, como a redução de trocas gasosas; diminuição da área foliar e, consequientemente, do índice de área foliar; redução no surgimento de novas folhas e aumento da abscisão foliar em virtude da elevação da concentração de ácido abscísico na planta, que é associado à quantidade de luz absorvida e à fotossíntese total da planta, reduzindo a produção de fotoassimilados (INMAN-BAMBER; SMITH, 2005; SMIT; SINGELS, 2006; GAVA et al., 2011). No entanto, essas características morfofisiológicas em resposta ao estresse hídrico são consideradas de grande importância para se obter elevadas produtividades em cultivos localizados em regiões que apresentem períodos de estiagem consideráveis, como o Cerrado Brasileiro (INMAN-BAMBER; SMITH, 2005).

Para o efeito isolado das variedades, foi observado que a RB867515 foi a variedade que apresentou os maiores valores de produtividade $\left(174,99 \mathrm{Mg} \mathrm{ha}^{-1}\right)$ e PC $(2,06 \mathrm{~kg})$. Porém, não houve diferença significativa para produtividade da variedade RB855156, que obteve $148,10 \mathrm{Mg} \mathrm{ha}^{-1}$ (Figura 5A). Por outro lado, a variedade RB855156 foi a que atingiu o maior número de perfilhos industrializáveis, com aumento de 21,40\% em relação às variedades RB867515 e RB835486. Tal superioridade no perfilhamento da variedade RB855156 proporcionou que esta apresentasse 
produtividade semelhante à variedade de referência (RB867515), mesmo apresentando o peso do colmo estatisticamente inferior (Figura 5).

(A)

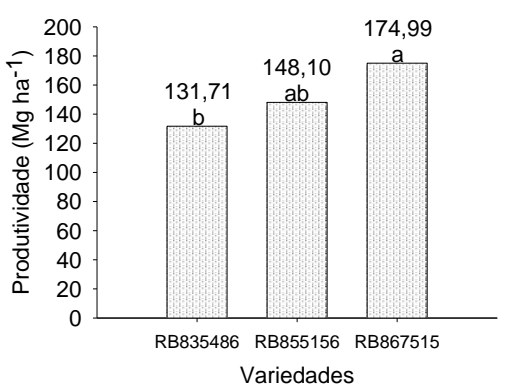

(B)

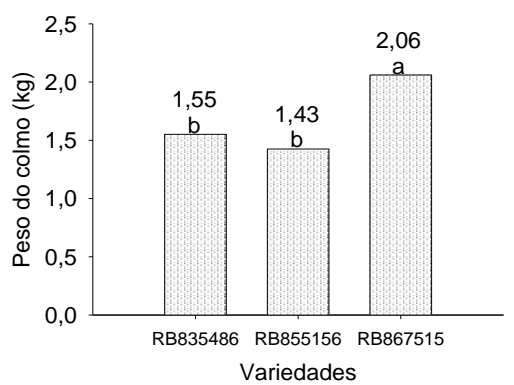

(C)

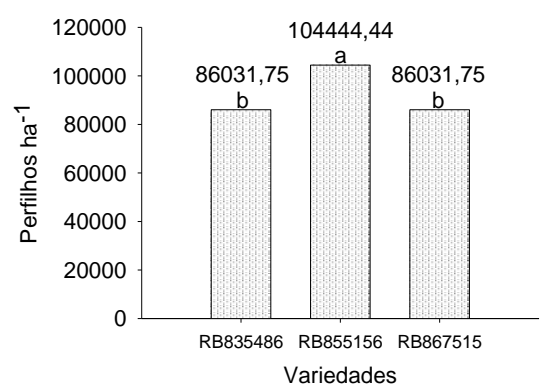

Figura 5. Produtividade, peso do colmo (PC) e o perfilhamento das variedades RB835486, RB855156 e RB867515 de cana-de-açúcar.

A produtividade da RB867515 foi superior aos 125,90 $\mathrm{Mg} \mathrm{ha}^{-1}$ registrados por Vieira et al. (2012) para a mesma variedade ao estudar lâminas referentes a 25, 50, 75, 100, 125 e 150\% da ETc com manejo da irrigação realizado para atender a demanda de 100\%, em uma área irrigada por pivô central no município de Jaíba-MG, também com cana-de-açúcar no quarto ciclo de produção. Porém, foi inferior às verificadas por Oliveira et al. (2011), que obtiveram valores máximos de 186 $\mathrm{Mg} \mathrm{ha}^{-1}$ com o genótipo RB867515 em cana-planta. Estes autores explicaram que a produtividade de genótipos de cana-de-açúcar também é influenciada diretamente pelo tipo de solo e a quantidade de cortes, o que justifica o decréscimo nos parâmetros de produtividade, o que é natural para a canade-açúcar com o avanço dos cultivos, sendo reflexo direto da diminuição do vigor da planta (COSTA et al., 2011). No entanto, mesmo no quarto ciclo de cultivo, o número de perfilhos industrializáveis por hectare, que correspondem a 15,66, 12,90 e 12,90 perfilho $\mathrm{m}^{-1}$ (RB855156, RB835486 e RB867515, respectivamente), foram superiores aos 12,00 para a variedade IAC862480 e 10,99 perfilho $\mathrm{m}^{-1}$ para a variedade RB72454, relatados por Silva et al. (2008) quando estudaram o perfilhamento em diferentes genótipos de cana-de-açúcar, com época de colheita equivalente ao presente trabalho, o que provavelmente pode estar relacionado à boa adaptação das variedades testadas na presente pesquisa às condições de altitude, solo e precipitação pluviométrica da Região Centro-Oeste.

Em variedades com menor perfilhamento, os colmos apresentam maior altura, maior diâmetro de colmo e maior acúmulo de matéria seca, o que indica correlação positiva com as variedades mais produtivas, sugerindo que o número de perfilhos industrializáveis é reduzido com a restrição da disponibilidade de água (RAMESH; MAHADEVASWANY, 2000). De fato, o perfilhamento é um dos componentes para a formação do potencial de produção da cana-de-açúcar, existindo correlação com a altura e o diâmetro de colmos (Silva et al., 2008) e a irrigação proporciona que as variedades responsivas manifestarem seu potencial genético. 
O cultivo com a irrigação equivalente a $75 \%$ da ETc foi o que mais se aproximou do máximo de produtividade e PC pelas variedades RB835486, RB855156 e RB867515 de cana-deaçúcar e este foi utilizado para a comparação com o cultivo em sequeiro ( $0 \%$ da ETc), de acordo com a Tabela 4. O regime hídrico que resultou em maiores produtividades $(75 \%$ da ETc) não apresentou diferença significativa para os parâmetros tecnológicos avaliados na matéria prima das variedades de cana-de-açúcar, havendo diferença significativa apenas para o efeito isolado das variedades testadas, com exceção para o PZA, AR e ARC, que não apresentaram diferença significativa entre os tratamentos (Tabela 4). Estes resultados discordam de Silva et al. (2014a), quando concluíram que a utilização de $75 \%$ de água recomendada para a irrigação, proporcionou melhor qualidade da matéria prima produzida em cultivo no Sudoeste Goiano, que tem uma distribuição de água mais homogênea e com um período de seca menor do que a região de Planaltina-DF.

Tabela 4. Resumo da análise de variância dos parâmetros tecnológicos: ${ }^{\circ} \mathrm{Brix}, \mathrm{Pol}, \mathrm{PZA}, \mathrm{AR}, \mathrm{ARC}$ Fibras, PCC, ATR, e VMgC das variedades RB835486, RB855156 e RB867515 de canade-açúcar cultivadas com irrigação equivalente a $75 \%$ da ETc.

\begin{tabular}{lcccccccccc}
\hline \multirow{2}{*}{ FV } & \multirow{2}{*}{ GL } & \multicolumn{10}{c}{ Quadrado médio } \\
\cline { 3 - 10 } & & ${ }^{\circ}$ Brix & Pol & PZA & AR & ARC & Fibra & PCC & ATR & VMgC \\
\hline Bloco & 2 & $0,18^{\text {ns }}$ & $0,55^{\text {ns }}$ & $6,55^{\text {ns }}$ & $0,007^{\text {ns }}$ & $0,004^{\text {ns }}$ & $0,06^{\text {ns }}$ & $0,35^{\text {ns }}$ & $25,76^{\text {ns }}$ & $5,95^{\text {ns }}$ \\
Variedade (V) & 2 & $7,43^{*}$ & $9,22^{*}$ & $20,78^{\text {ns }}$ & $0,001^{\text {ns }}$ & $0,001^{\text {ns }}$ & $1,93^{*}$ & $5,96^{*}$ & $480,02^{*}$ & $112,99^{*}$ \\
Resíduo a & 4 & 0,48 & 1,09 & 7,82 & 0,014 & 0,009 & 0,18 & 0,82 & 64,98 & 14,99 \\
Irrigação (I) & 1 & $0,06^{\text {ns }}$ & $0,0001^{\text {ns }}$ & $1,55^{\text {ns }}$ & $0,017^{\text {ns }}$ & $0,012^{\text {ns }}$ & $0,22^{\text {ns }}$ & $0,01^{\text {ns }}$ & $1,62^{\text {ns }}$ & $0,37^{\text {ns }}$ \\
V x I & 2 & $0,33^{\text {ns }}$ & $0,47^{\text {ns }}$ & $1,67^{\text {ns }}$ & $0,037^{\text {ns }}$ & $0,025^{\text {ns }}$ & $0,12^{\text {ns }}$ & $0,37^{\text {ns }}$ & $28,67^{\text {ns }}$ & $6,61^{\text {ns }}$ \\
Resíduo b & 6 & 1,19 & 1,91 & 8,16 & 0,052 & 0,037 & 0,12 & 1,29 & 102,72 & 23,68 \\
\hline Média & & 17,12 & 14,38 & 83,82 & 0,79 & 0,67 & 10,46 & 12,50 & 127,11 & 61,04 \\
\hline CV1 (\%) & & 4,06 & 7,26 & 3,34 & 15,10 & 14,01 & 4,08 & 7,25 & 6,34 & 6,34 \\
CV2 (\%) & & 6,37 & 9,62 & 3,41 & 28,67 & 28,59 & 3,37 & 9,12 & 7,97 & 7,97 \\
\hline
\end{tabular}

FV: fonte de variação; GL: grau de liberdade; CV: coeficiente de variação; c: colmo; ns: não significativo; * e **: respectivamente significativo para $\mathrm{p}<0,05$ e $\mathrm{p}<0,01$; ${ }^{\circ}$ Brix $(\%)$ - ${ }^{\circ}$ Brix do caldo; Pol (\%) - Pol do caldo; PZA (\%) Pureza do caldo; AR (\%) - Açúcares redutores do caldo ou teor de açúcares redutores (glicose e frutose, oriundos da hidrólise da sacarose) por cento, em peso, de caldo da cana-de-açúcar; ARC (\%) - Açúcares redutores da cana; Fibra (\%) - fibra da cana, ou teor de material insolúvel em água, por cento, em peso, de cana; PCC (\%) - Pol da cana ou teor de sacarose aparente por cento, em peso de cana; ATR $\left(\mathrm{kg} \mathrm{Mg} \mathrm{de} \mathrm{cana}^{-1}\right)$ - Açúcar total recuperável ou teor de açúcares totais (glicose, frutose e sacarose), em quilos por tonelada de cana; $\operatorname{VMgC}\left(\mathrm{R} \$ \mathrm{Mg}^{-1}\right)$ - Valor base para a cana, em real por megagrama, posta na esteira da unidade industrial.

No geral, para os parâmetros tecnológicos que definem a qualidade industrial da canade-açúcar, quando cultivada com irrigação equivalente a 75\% da ETc, a variedade RB855156 foi a que obteve maior qualidade industrial, apresentando maiores valores absolutos de ${ }^{\circ}$ Brix, Pol, PCC e $\operatorname{ATR}(18,21 \%, 15,67 \%, 16,98 \%$ e $15,02 \%$, respectivamente), equivalente a um incremento de $13,96 \%, 18,71 \%, 16,98 \%$ e 15,02 para os respectivos parâmetros em relação a variedade de RB835486, não diferenciando estatisticamente da variedade de referência (RB867515) para estes parâmetros (Figura 6). Não houve diferença significativa para AR, ARC e PZA das variedades testadas. 
(A)

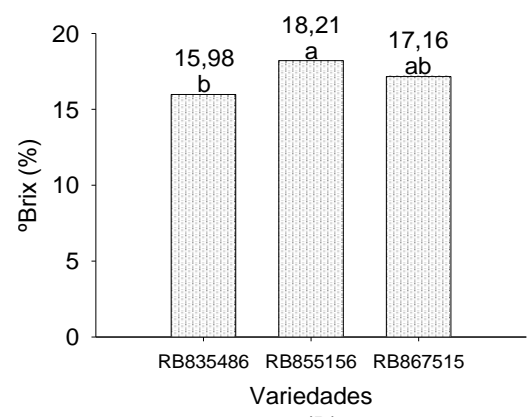

(D)

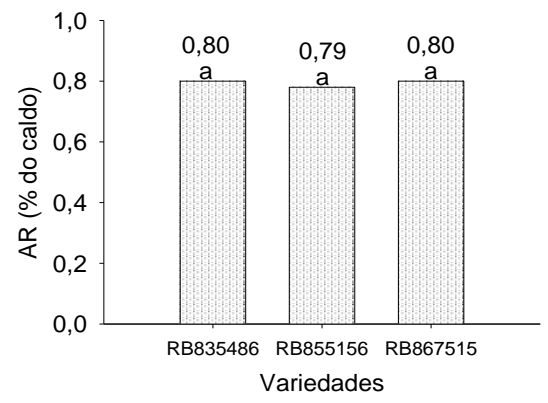

(G)

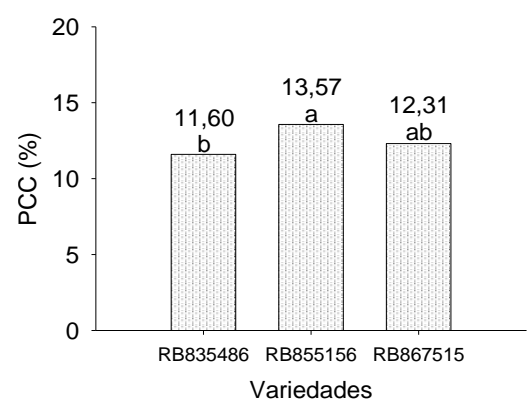

(B)

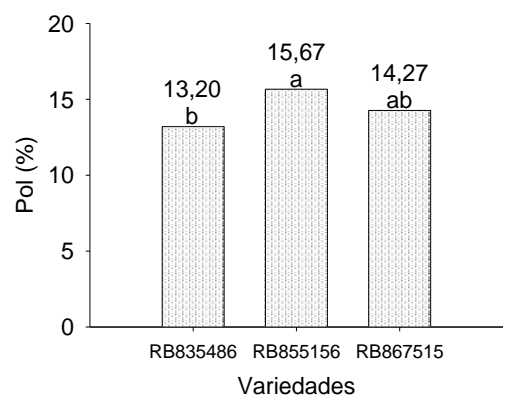

(E)

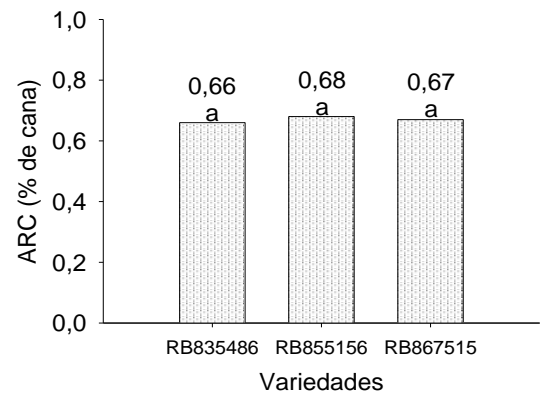

(H)

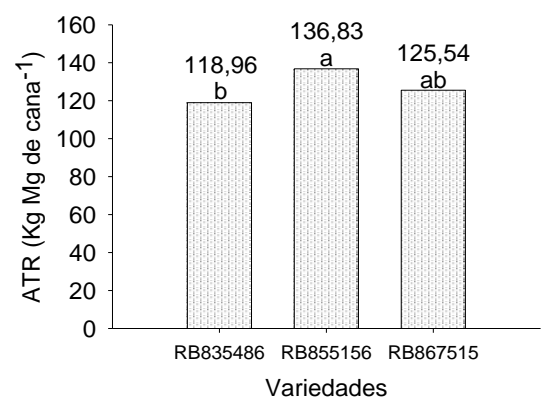

(C)

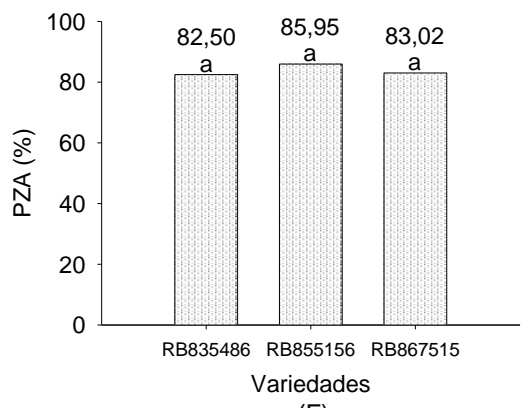

(F)

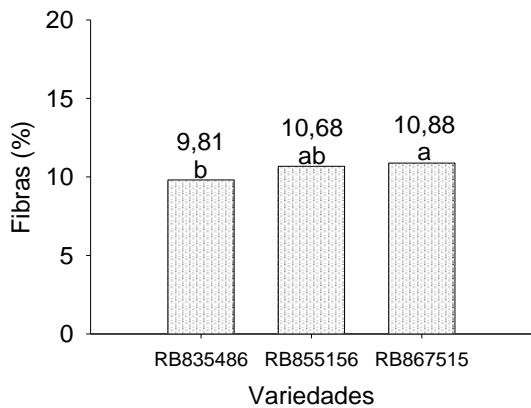

(I)

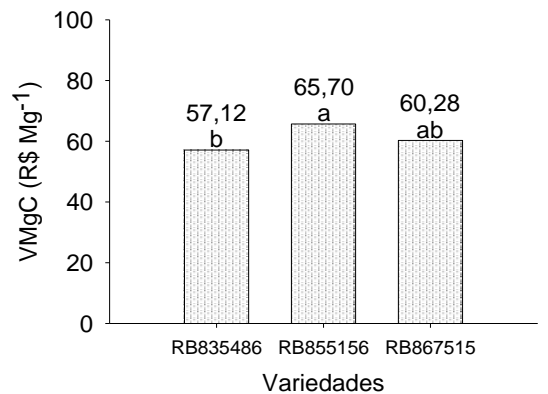

Figura 6. Características tecnológicos das variedades RB835486, RB855156 e RB867515 de canade-açúcar cultivada com irrigação equivalente a $75 \%$ da ETc. ${ }^{\circ}$ Brix $(\%)$ - ${ }^{\circ}$ Brix do caldo; Pol (\%) - Pol do caldo; PZA (\%) - Pureza do caldo; AR (\%) - Açúcares redutores do caldo ou teor de açúcares redutores (glicose e frutose, oriundos da hidrólise da sacarose) por cento, em peso, de caldo da cana-deaçúcar; ARC (\%) - Açúcares redutores da cana; Fibra (\%) - fibra da cana, ou teor de material insolúvel em água, por cento, em peso, de cana; PCC (\%) - Pol da cana ou teor de sacarose aparente por cento, em peso de cana; ATR ( $\mathrm{kg} \mathrm{Mg}$ de cana ${ }^{-1}$ - Açúcar total recuperável ou teor de açúcares totais (glicose, frutose e sacarose), em quilos por tonelada de cana; $\operatorname{VMgC}\left(\mathrm{R} \$ \mathrm{Mg}^{-1}\right)$ - Valor base para a cana, em real por megagrama, posta na esteira da unidade industrial.

Oliveira et al. (2011) e Macêdo et al. (2012) também não observaram diferença significativa nos atributos tecnológicos em variedades da cana-de-açúcar cultivadas sob diferentes regimes hídricos, com exceção do ${ }^{\circ}$ Brix que apresentou decréscimo com o uso da irrigação. Do mesmo modo, Deon et al. (2010) também afirmaram que a irrigação proporcionou menor ${ }^{\circ}$ Brix, mas não influenciou no ATR e PCC. Por outro lado, Moura et al. (2014) e Correia et al. (2014) discordam de tal afirmação quando estudaram a variedade SP791011 em Capim-PB (precipitação anual de $1000 \mathrm{~mm}$ com seis meses sem registro de precipitação, 39,56\% menor que a média da Região de Cerrado onde foi desenvolvida a presente pesquisa), e explicaram que o uso da irrigação 
melhorou a qualidade industrial da cana-de-açúcar, sendo significativo para o Pol e PZA, porém não alterando os resultados do PCC, fibras e ${ }^{\circ}$ Brix.

Os valores médios de AR (açúcares redutores do caldo) das variedades estudadas foram superiores à média de 6,3\% observadas por Silva et al. (2014a) ao estudarem a qualidade industrial da cana-de-açúcar sob diferentes lâminas de água no Sudoeste Goiano (onde ocorre menos stress hídrico), afirmando que altos valores de AR, associados a um alto valor de fibras, correspondem a uma menor qualidade da cana, impactando diretamente na concentração de sacarose da matéria prima. Entretanto, a porcentagem de fibra de 9,81\%, 10,86\% e 10,88\% (RB835486, RB855156 e RB867515, respectivamente) proporcionou uma melhoria da qualidade industrial da matéria prima, inferior aos 16,65\% de fibras para a SP791011 verificado por Correia et al. (2014), 12 a 14\% por Silva et al. (2014a) para a variedade RB867515 em cultivo irrigado, aos 11,02 a 11,57\% por Oliveira et al (2009) para a SP801816 de terceira soca, e aos 14,17\% médios das variedades testadas por Costa et al (2011) em terceira soca.

Os teores de fibras resultam em cana com menos dureza, porém, teor de fibra inferior a $10,5 \%$ é indesejável para a indústria sucroalcooleira por causa do balanço energético nas usinas e alambiques, pois é necessário queimar mais bagaço para manter o poder calorífico nas caldeiras, sendo o teor médio ideal de 10,5 a 12,5\% (OLIVEIRA et al., 2009). De acordo com Fernandes (2000), o teor de fibras da cana-de-açúcar no Estado de São Paulo deve estar entre 10 a $11 \%$ para que seja recomendada a industrialização. Neste trabalho, com exceção da variedade RB835486, observou-se que os teores de fibra estão de acordo com o recomendado pela literatura.

Foi observado maior valor do PCC (Pol da cana) para a variedade RB855156, sendo 16,98\% maior que o obtido da variedade RB835486 e não diferenciando da variedade RB867515. Os dados de PCC obtidos no presente trabalho são inferiores aos 14,60\% médios de Correia et al. (2014) para a variedade SP79-1011 em cana-planta. Por outro lado, os resultados da presente pesquisa ficou entre os 13 a 15,50\% observados por Oliveira et al. (2011) para a RB85-5453 também na situação de cana-planta e em cultivo irrigado e sequeiro, respectivamente. Semelhante também aos 13,75\% médios para o PCC foram observados por Dantas Neto et al. (2006) ao estudarem o comportamento da variedade SP79-1011, em primeira soca, à diferentes níveis de irrigação e adubação. Como também aos 13,09\% médios observados por Costa et al. (2011) ao estudarem crescimento e produtividade de quatro variedades de cana-de-açúcar no quarto ciclo de cultivo, o que sugere que mesmo na terceira soca, as variedades ainda apresentam PCC aceitável para o uso industrial.

O ATR da variedade RB855156, que representa teor de açúcares totais (glicose, frutose e sacarose), em quilos por tonelada de cana, foi 5,13\% superior à média do ATR produzido pela Região Centro Sul do país (133 $\mathrm{kg} \mathrm{Mg}^{-1}$ ), mas apresentou resultados inferiores aos $153,6 \mathrm{~kg} \mathrm{Mg}^{-1}$ 
por Oliveira et al., (2011) para a variedade RB867515 (cana-planta) em cultivo irrigado e aos valores observados por Vieira et al. (2012) para a mesma variedade em cana-soca $\left(143,3 \mathrm{~kg} \mathrm{Mg}^{-1}\right.$ ) e média semelhante a quatro variedades de terceira soca, cultivadas em sequeiro $\left(128,48 \mathrm{~kg} \mathrm{Mg}^{-1}\right)$ (COSTA et al., 2011). Tais resultados reforçam ainda mais que, mesmo com o declínio natural do ciclo, proposto por COSTA et al. (2011), as variedades avaliadas, com exceção da RB835486, apresentam boa adaptabilidade às condições climáticas da Região Centro-Oeste do Brasil, assim como a potencialidade dessa Região para o setor sucroalcooleiro no País.

De acordo com Farias et al. (2009) o PZA obtido foi aceitável, ficando entre 82 e 90\%, o que significa a excelente qualidade industrial das três variedades testadas, além de apresentarem produtividade muito acima da média nacional. No Estado de São Paulo, os valores mínimos de PZA do caldo devem ser de $80 \%$ (início da safra) ou 85\% (transcorrer da safra) para que seja recomendada a industrialização da cana-de-açúcar (SILVA et al., 2014b). Segundo estes autores, é o elevado valor de PZA que confirma a alta concentração de sacarose no caldo das variedades, refletindo diretamente com altos rendimentos da matéria prima produzida, melhorando também a qualidade do caldo devido à redução na quantidade de aminoácidos, ácidos orgânicos, amido, açúcares redutores, além de outros precursores e formadores de cor.

Apesar de não haver diferença significativa para o valor do megagrama de colmo (VMgC) entre as variedades RB855156 e a RB867515, foi a RB855156 que teve valores médios absolutos mais satisfatórios para a matéria prima produzida, pois mesmo com o PC com 30,58\% inferior a variedade de referência (RB867515), obteve produtividade equivalente a esta, apresentando ainda excelentes resultados para os parâmetros tecnológicos testados, como maior ${ }^{\circ}$ Brix, Pol, PCC, e 9,89\% menos fibras que a RB867515. Estes fatores combinados influenciaram no valor do produto produzido, proporcionando para $\mathrm{RB} 855156$ um $\mathrm{VMgC} 15,02 \%$ maior que a variedade de RB835486. Porém, as variedades testadas não diferenciaram em AR, ARC e PZA do caldo.

No Estado de São Paulo, que é atualmente o maior produtor de cana-de-açúcar do Brasil, a maior parte das áreas canavieiras é cultivada em condições de sequeiro, onde tradicionalmente é considerado inviável a irrigação para as condições climáticas da região, que possuem clima do tipo Aw (Tropical Estacional), pela classificação de Köpper (SILVA et al., 2014a), sendo o tipo climático típico do Cerrado Brasileiro, caracterizado por apresentar períodos bem definidos de chuva e seca, no entanto pode apresentar considerável variação climática pela sua grande distribuição e extensão no território brasileiro. Mesmo assim, a maturação da cana-de-açúcar na Região Centro-Oeste, que ocorreu no final do período chuvoso, entre abril a maio, época com temperaturas mais baixas, não afetaram significativamente a qualidade da cana em função do acúmulo de sacarose, discordando do sugerido por Moura et al. (2014) para a mesma região. 
Em todo o Brasil os produtores de cana-de-açúcar têm sido remunerados pelos índices qualitativos, de modo que o preço pago por tonelada de colmos é diretamente proporcional à qualidade da matéria prima (FARIAS et al., 2009). Nesse contexto, em cultivos de cana-de-açúcar no Centro-Oeste Brasileiro, a variedade de referencia (RB867515), pode chegar a uma receita bruta de $\mathrm{R} \$ 10.548,40 \mathrm{ha}^{-1}$, seguido da RB855156 com R \$ 9.730,17 ha ${ }^{-1}$ e, por último, a RB835486 com $\mathrm{R} \$ 7.523,28 \mathrm{ha}^{-1}$.

Esses resultados reforçam a viabilidade da expansão da produção sucroalcooleira para o Cerrado do Centro-Oeste do Brasil, e mesmo apresentando um período de estiagem com pouca ou nenhuma precipitação pluviométrica, diferente de outras regiões do País, a cultura da cana-deaçúcar responde satisfatoriamente sem o uso da irrigação suplementar, alcançando resultados de produtividade e qualidade industrial satisfatórios para a matéria prima produzida, mesmo após quatro cortes na cultura. Além disso, no quarto ciclo (terceira soca) foi observado que as variedades apresentaram máximo de produtividade 147,7\% (irrigado - 69,01\% da ETc) e 49,31\% (sequeiro 0\% da ETc) superior à média nacional na safra do mesmo ano - safra 2013/2014 (CONAB, 2014), o que demonstra a boa via útil do canavial, o que não justifica a sua reforma com aproximadamente 4 a 5 anos, ou produtividade de $65 \mathrm{Mg} \mathrm{ha}^{-1}$ como indicado na literatura, por ser ainda economicamente produtivo (SILVA et al., 2010). 


\subsection{CONCLUSÕES}

A variedade RB867515 e a RB855156 foram as que obtiveram maior produtividade média, com 174,99 e 148,10 $\mathrm{Mg} \mathrm{ha}^{-1}$, respectivamente.

A variedade RB855156 apresentou maior número de perfilhos por hectare.

A variedade RB867515 foi a que obteve maior peso médio de colmo (PC), com 2,06 kg.

A cana-de-açúcar cultivada com irrigação equivalente a $75 \%$ da ETc não proporcionou diferença significativa para a qualidade industrial entre as variedades RB835486, RB855156 e RB867515 em relação ao cultivo em sequeiro (0\% da ETc).

Não houve diferença significativa para os valores do teor de açúcares redutores (glicose e frutose, oriundos da hidrólise da sacarose) por cento, em peso, de caldo da cana-de-açúcar (AR), açúcares redutores da cana (ARC) e a pureza do caldo (PZA) entre as variedades RB835486, RB855156 e RB867515. 


\subsection{REFERÊNCIAS BIBLIOGRÁFICAS}

ASSIS, P. C. O.; LACERDA, R. D. L.; AZEVEDO, H. M.; DANTAS NETO, J.; FARIAS, C. H. A. Resposta dos parâmetros tecnológicos da cana-de-açúcar a diferentes lâminas de irrigação e adubação. Revista de Biologia e Ciências da Terra, São Cristóvão, v.4, n.2, 2004.

BENINCASA, M. M. P. Análise de crescimento de plantas: noções básicas. Jaboticabal: Funep. 1988. 42p.

BRASIL. MINISTÉRIO DA AGRICULTURA, PECUÁRIA E ABASTECIMENTO. Plano Nacional de Agroenergia: 2006-2011. 2.ed. Brasília: Embrapa Informação Tecnológica, 2006. $114 \mathrm{p}$.

BURNQUIST, H. L. O sistema de remuneração da tonelada de cana pela qualidade CONSECANA. Preços Agrícolas, Piracicaba, v.14, n.148, p.14-16, 1999.

CAMARGO, M. S.; VITTI, A. C. Produção de palhada e colmos de variedades de cana-de-açúcar. Pesquisa \& Tecnologia, vol.11, n.1, 2014.

CARLIN, S. D.; SILVA, M. A.; ROSSETTO, R. Parâmetros biométricos e rodutividade da canade-açúcar após tombamento dos colmos. Bragantia, Campinas, v.67, n.4, p.845-853, 2008.

CARVALHO, C. M.; AZEVEDO, H. M.; DANTAS NETO, J.; FARIAS, C. H. A.; SILVA, C. T. S.; GOMES FILHO, R. R. Rendimento de açúcar e álcool da cana-de-açúcar submetida a diferentes níveis de irrigação. Revista Brasileira de Ciências Agrárias, Recife, v.4, p.72-77, 2009.

CONAB, Companhia Nacional de Abastecimento. Acompanhamento de safra brasileira: canade-açúcar, v.1-Safra 201/2015, n.1- Primeiro levantamento, abril/2014. Brasília: Conab, 2014. 20 p.

CONSECANA. Conselho dos Produtores de Cana-de-açúcar, Açúcar e Álcool do Estado de São Paulo. Manual de instruções. 5. ed. , Piracicaba: Consecaca, 2006. 112p.

CORREIA, C. B. G.; AZEVEDO, H. M.; DANTAS NETO, J.; CARVALHO, C. M.; SILVA, L. L.; FEITOSA, S. O. Cana-de-açúcar: parâmetros tecnológicos em função de diferentes lâminas de irrigação e adubação de cobertura. Revista Brasileira de Agricultura Irrigada, Fortaleza, v8, n.1, p.26-37, 2014.

COSTA, C. T. S.; FERREIRA, V. M.; ENDRES, L.; FERREIRA, D. T. R. G.; GONÇALVES, E. R. Crescimento e produtividade de quatro variedades de cana-de-açúcar no quarto ciclo de cultivo. Revista Caatinga, Mossoró, v. 24, n. 3, p. 56-63, 2011.

DANTAS NETO, J.; FIGUEIRÊDO, J. L. C.; FARIAS, C. H. A.; AZEVEDO, H. M.; AZEVEDO, C. A. V. Resposta da cana-de-açúcar, primeira soca, a níveis de irrigação e adubação de cobertura. Revista Brasileira de Engenharia Agrícola e Ambiental, Campina Grande, v.10, n.1, p.283-288, 2006.

DAROS, E.; OlIVEIRA, R. A.; ZAMBON, J. L. C.; FILHO, J. C. B. Catálogo nacional de variedades "RB” de cana-de-açúcar. Curitiba: Ridesa, 2010. 136 p.

DEON, M. D.; GOMES, T. M.; MELFI, A. J.; MONTES, C. R.; SILVA, E. Produtividade e qualidade da cana- de- açúcar irrigada com efluente de estação de tratamento de esgoto. Pesquisa Agropecuária Brasileira, Brasília, v.45, p.1149- 1156, 2010. 
DOORENBOS, J.; KASSAM, A. H. Efeito da água no rendimento das culturas. Campina Grande: UFPB, 1994. 306p. (Estudos FAO: Irrigação e Drenagem, 33).

EMBRAPA. Sistema Brasileiro de Classificação dos Solos. Rio de Janeiro: Embrapa Solos, 2006. $306 \mathrm{p}$.

FARIAS, C. H. A.; FERNANDES, P. D.; GHEYI, H. R.; DANTAS NETO, J. Qualidade industrial de cana-de-açúcar sob irrigação e adubação com zinco, em Tabuleiro Costeiro paraibano. Revista Brasileira de Engenharia Agrícola e Ambiental, Campina Grande, v.13, n.4, p.419-428, 2009.

FERNANDES, A.C. Cálculos na agroindústria da cana- de- açúcar. Revista Stab: Açúcar, Álcool e Subprodutos, Piracicaba, v.11, p.55-65, 2000.

FERREIRA, D. F. Sisvar: a computer statistical analysis system. Ciência e Agrotecnologia, v. 35, n.6, p. 1039-1042, 2011.

FLEXAS, J.; RIBAS-CARBO, M.; BOTA, J.; GALMES, J.; HENKLE, M.; MARTINEZCANELLAS, S.; MEDRANO, H. Decreased Rubisco activity during water stress is not induced by decreased relative water content but related to conditions of low stomatal conductance and chloroplast CO2 concentration. New Phytologist, Lancaster, v.172, p.73-82, 2006.

GALLO, D.; NAKANO, O.; SILVEIRA NETO, S.; CARVALHO, R. P. L.; BAPTISTA, G. C.; BERTI FILHO, E.; PARRA, J. R. P.; ZUCCHI, R. A.; ALVES, S. B.; VENDRAMIM, J. D.; MARCHINI, L. C.; LOPES, J. R. S.; OMOTO, C. Entomologia Agrícola. Piracicaba: FEALQ, 2002, 920 p.

GAVA, G. J. C.; SILVA, M. A.; SILVA, R. C.; JERONIMO, E. M.; CRUZ, J. C. S.; KÖLLN, O. T. Produtividade de três cultivares de cana-de-açúcar sob manejos de sequeiro e irrigado por gotejamento. Revista Brasileira de Engenharia Agrícola e Ambiental, Campina Grande, v.15, n.3, p.250-255, 2011.

HANKS, R. J.; RASMUSSEN, V. P.; WILSON, G. D. Line-source sprinkler for continuous variable irrigation crop production studies. Soil Science Society of America Journal. Madison, v. 40, p. 426-429, 1976.

INMAN- BAMBER, N.G.; SMITH, D.M. Water relations in sugarcane and response to water deficits. Field Crops Research, Amsterdam, v.92, p.185-202, 2005.

LEITE, G. H. P.; CRUSCIOL, C. A. C.; SILVA, M. A. Desenvolvimento e produtividade da canade-açúcar após aplicação de reguladores vegetais em meio de safra. Semina: Ciências Agrárias, Londrina, v. 32, n. 1, p.129-138, 2011.

MACÊDO, G. A. R.; COSTA, E. L., VIANA, M. C. M., FERREIRA, J. J.; PIRES, J. F.; FREIRE, F. M. Características agronômicas e químicas das variedades de cana-de-açúcar RB83-5486 e RB86-7515 sob irrigação e sequeiro. Revista Brasileira de Engenharia Agrícola e Ambiental, Campina Grande, v.16, n.6, p. 599-603, 2012.

MAULE, R. F.; MAZZA, J. A.; MARTHA JUNIOR, G. B. Produtividade agrícola de cultivares de cana-de-açúcar em diferentes solos e épocas de colheita. Scientia Agricola, Piracicaba, v.58, n.2, p.295-301, abr./jun. 2001. 
MONTEITH, J. L. Evaporation and Environment. 19th Symposia of the Society for Experimental Biology, University Press, Cambridge, v. 19, p.205-234, 1965.

MOURA, L. C.; SILVA, N. F.; CUNHA, F. N.; BASTOS, F. J. C.; CÉLIA, J. A.; TEIXEIRA, M. B. Índice de maturação da cana-de-açúcar fertirrigada sobre diferentes lâminas. Revista Brasileira de Agricultura Irrigada, Fortaleza, v.8, n.1, p.64-76, 2014.

MOURA, M. V. P. F.; FARIAS, C. H. A.; AZEVEDO, C. A. V.; DANTAS NETO, J.; AZEVEDO, H. M.; PORDEUS, R. V. Doses de adubação nitrogenada e potássica em cobertura na cultura da cana-de-açúcar, primeira soca, com e sem irrigação. Ciência e Agrotecnologia, Lavras, v.29, p.753-760, 2005.

OLIVEIRA, E. C. A.; FREIRE, F. J.; OLIVEIRA, A. C.; SIMÕES NETO, D. E.; ROCHA, A. T.; CARVALHO, L. A. Produtividade, eficiência de uso da água e qualidade tecnológica de cana- de- açúcar submetida a diferentes regimes hídricos. Pesquisa Agropecuária Brasileira, Brasília, v.46, n.6, p.617-625, jun. 2011.

OLIVEIRA, E. L.; ANDRADE, L. A. B.; FARIA, M. A.; EVANGELISTA, A. W. P.; MORAIS, A. R. Uso de vinhaça de alambique e nitrogênio em cana- de- açúcar irrigada e não irrigada. Pesquisa Agropecuária Brasileira, Brasília, v.44, n.11, p.1398-1403, nov. 2009.

SACHS, R. C. Remuneração da tonelada de cana-de-açúcar no estado de São Paulo. Informações Econômicas, São Paulo, v.37, n.2, 2007.

SANO. S. M.; ALMEIDA, S. P.; RIBEIRO, J. F. Cerrado: ecologia e flora. Embrapa Cerrados. Brasília: Embrapa Informação Tecnológica, 2008. 2v. 1279 p.

SILVA, M. A.; ARANTES, M. T.; RHEIN, A. F. L.; GAVA, G. J. C.; KOLLN, O. T. Potencial produtivo da cana-de-açúcar sob irrigação por gotejamento em função de variedades e ciclos. Revista Brasileira de Engenharia Agrícola e Ambiental, Campina Grande, v.18, n.3, p.241-249, 2014b.

SILVA, M. A.; CATO, S. C.; COSTA, A. G. F. Produtividade e qualidade tecnológica da soqueira de cana-de-açúcar submetida à aplicação de biorregulador e fertilizantes líquidos. Ciência Rural, Santa Maria, v.40, p.774-780, 2010.

SILVA, M. A.; SILVA, J. A. G.; ENCISO, J.; SHARMA, V.; JIFON, J. Yield components as indicators of drought tolerance of sugarcane. Scientia Agricola, Piracicaba, v.65, p.620-627, 2008.

SILVA, N. F.; MOURA, L. C.; CUNHA, F. N.; RIBEIRO, P. H.; CARVALHO, J. J.; TEIXEIRA, M. B. Qualidade industrial da cana-de-açúcar fertirrigada sob diferentes lâminas de água no sudoeste goiano. Revista Brasileira de Agricultura Irrigada, Fortaleza, v.8, n.3, p.280-295, 2014a.

SINGH, P.N.; SHUKLA, S.K.; BHATNAGAR, V.K. Optimizing soil moisture regime to increase water use efficiency of sugarcane (Saccharum spp. Hybrid complex) in subtropical India. Agricultural Water Management, Amsterdam, v.90, p.95- 100, 2007.

SMIT, M. A.; SINGELS, A. The response of sugarcane canopy development to water stress. Field Crops Research, Amsterdam, v.98, p.91-97, 2006. 
VIEIRA, G. H. S.; MANTOVANI, E. C.; SEDIYAMA, G. C.; COSTA, E. L.; DELAZARI, F. T. Produtividade de colmos e rendimento de açúcares da cana-de-açúcar em função de lâminas de água. Irriga, Botucatu, v. 17, n. 2, p. 234 - 244, abril-junho, 2012.

VISWANATHAN, R.; SAMIYAPPAN, R. Induction of systemic resistence by fluorescent pseudomonads against red rot disease of sugarcane caused by Colletotrichum falcatum. Crop Protection, Guildford,v.21, p.1-10, 2002. 


\section{CAPÍTULO III}

PARÂMETROS FISIOLÓGICOS EM VARIEDADES DE CANA-DE-AÇÚCAR SUBMETIDAS AO DÉFICIT HÍDRICO 


\section{CAPÍTULO III - RESPOSTAS FISIOLÓGICOS EM VARIEDADES DE CANA-DE- AÇÚCAR SUBMETIDAS AO DÉFICIT HÍDRICO}

\subsection{RESUMO}

A baixa disponibilidade hídrica afeta negativamente os cultivos agrícolas e é a principal causa da redução da produtividade no setor sucroalcooleiro no Brasil. O objetivo deste trabalho foi caracterizar fisiologicamente as variedades da cana-de-açúcar, submetidas a diferentes regimes hídricos. O experimento foi conduzido em um delineamento em blocos ao acaso com três repetições em parcelas subdivididas no tempo, com três variedades: RB855156, RB835486 e RB867515 (parcela), ausência e presença da irrigação (irrigado e sequeiro - subparcela) e quatro coletas de dados no tempo (100, 150, 200 e 250 dias após o corte - DAC) que foram as subsubparcelas. A irrigação foi aplicada conforme o sistema Line Source Sprinkler System, de forma que a lâmina de água aplicada no tratamento irrigado foi equivalente a $100 \%$ da evapotranspiração da cultura (ETc) no centro da área do experimento, e nas extremidades o cultivo foi em sequeiro, que só recebeu uma irrigação de salvamento logo após o corte, e o fornecimento de água foi suspenso após a aplicação desta lâmina de água. Foram avaliados os seguintes características fisiológicas: prolina livre a folha, trocas gasosas foliares (E, $\left.\mathrm{g}_{\mathrm{s}}, \mathrm{A}, \mathrm{Ci}, \mathrm{EUA}, \mathrm{EIUA}, \mathrm{EC}\right)$ e a concentração foliar de clorofilas $(a, b$ e total). Nas avaliações, foi utilizada a folha +3 . Os dados foram submetidos à análise de variância e regressão a p<0,05. As variedades de cana-de-açúcar RB835486, RB855156 e RB867515 cultivadas em sistema de sequeiro apresentaram redução na transpiração (E), condutância estomática $\left(\mathrm{g}_{\mathrm{s}}\right)$, fotossíntese líquida (A), carboxilação (EC), clorofila $a$ (Clo $a$ ), clorofila total (Clo $a+b)$, e aumento da eficiência intrínseca do uso da água (EIUA).

Palavras-chave: Saccharum spp. L., estresse hídrico, prolina, trocas gasosas. 
BIOMETRIC RESPONSES OF THIRD RATOON SUGARCANE VARIETIES UNDER VARIABLE WATER REGIME

\subsection{ABSTRACT}

Low water supply affects negatively agricultural crops and is the main cause of reduced productivity in the sugar and ethanol industry in Brazil. The objective of this paper was to characterize physiologically the varieties of sugar cane under different water regimes. The experiment was performed using randomized design with three replicates in parcels subdivided in time, with three varieties: RB855156, RB835486 e RB867515 (plots), with absence and presence of irrigation (irrigated and rainfed - subplots) to which the plants were subjected, and data collection in four observations in time (100, 150, 200 and 250 days after harvest - DAC), that were the subsubplots. In the experiment, irrigation was applied according to Line Source Sprinkler System, so that the water applied in the irrigated treatment was equivalent to $100 \%$ of culture's evapotranspiration (ETc) in the center of experimental area, and in theextremities rainfed cultivation, which only received salvage irrigation right after harvest, and totally cutting off water supply. The following physiological characteristics were assessed: free proline in leaves, leaf gas exchange (E, $\left.\mathrm{g}_{\mathrm{s}}, \mathrm{A}, \mathrm{C}, \mathrm{USA}, \mathrm{EIUA}, \mathrm{EC}\right)$ and leaf chlorophyll concentration $(a, b$ and total). Leaf +3 was used for all evaluations. Data were subjected to analysis of variance and regression ( $\mathrm{p}<0.05)$. The varieties of sugarcane RB835486, RB855156 and RB867515 cultivated in rainfed system had reduced transpiration $(\mathrm{E})$, stomatal conductance $\left(\mathrm{g}_{\mathrm{s}}\right)$, net photosynthesis $(\mathrm{A})$, carboxylation (EC), chlorophyll a (Clo a), total chlorophyll (Clo $a+b)$, and increased intrinsic water use efficiency (IWUE).

Keywords: Saccharum spp L., water stress, proline, gas exchange. 


\subsection{INTRODUÇÃO}

A cana-de-açúcar (Saccharum spp. L.) é uma cultura que tem se destacado no mercado internacional pela sua importância econômica, social e ambiental; é cultivada em grandes áreas e é utilizada para a geração de matéria prima para as agroindústrias do açúcar, álcool e subprodutos, sendo importante fonte de energia renovável (BRASIL, 2006). O Brasil é atualmente o maior produtor mundial, responsável por 35\% da produção total, seguido da Índia e Austrália (COSTA et al., 2011). São produzidas no país aproximadamente 671,7 milhões de toneladas (safra 2014/15), com uma produtividade média de 73,6 $\mathrm{Mg} \mathrm{ha}^{-1}$, em uma área de aproximadamente 8,735 milhões de ha, e em constante expansão (CONAB, 2014).

Com o recente desafio da exploração canavieira na Região Centro-Oeste do país, onde tem ocorrido uma tendência de crescimento na produção nas safras atuais (CONAB, 2014), e com quase sua totalidade em áreas de Cerrado, a regularidade das chuvas e a disponibilidade hídrica deve ser cuidadosamente observada, devido ao longo período de estiagem característico do Bioma (SANO et al., 2008; SILVA et al., 2008). Isso faz com que as características climáticas sejam um fator determinante na escolha das variedades para o plantio, o que pode favorecer efeitos danosos ao cultivo da cana-de-açúcar, caso o período de maior necessidade hídrica da cultura não coincida com a estação chuvosa do Bioma. O déficit hídrico é uma das principais causas da redução da produtividade nos canaviais do Brasil, e por isso, são necessários estudos para se compreender os mecanismos de respostas da cultura a esse tipo de estresse (SMIT; SINGELS, 2006).

A necessidade hídrica no cultivo da cana-de-açúcar é variável de acordo com a fase fenológica, o que possibilita um manejo de irrigação e época de plantio mais eficientes, evitando-se perdas na produtividade, produção de biomassa e acúmulo de sacarose (DANTAS NETO et al., 2006; MOURA et al., 2014).

No entanto, estudos confirmam que as respostas ao estresse hídrico podem variar entre genótipos (SILVA et al., 2008). As variedades que são consideradas tolerantes ao estresse hídrico podem apresentar respostas diferenciadas a nível morfológico, fisiológico e molecular em virtude de muitas características da cana-de-açúcar terem controle multigênico (RODRIGUES, et al,. 2009). A avaliação dos efeitos do estresse hídrico sobre os parâmetros fisiológicos e sua relação com a produtividade, pode ser usada como indicador em plantas submetidas a estresses abióticos auxiliando também os programas de melhoramento vegetal a selecionar genótipos produtivos para condições de Regiões que tenham períodos de restrição hídrica (ASHRAF; FOOLAD, 2007; SILVA et. al., 2008; CARLIN; SANTOS, 2009).

Uma das estratégias adaptativas dos vegetais aos múltiplos efeitos causados pelos estresses é o ajustamento osmótico que está correlacionado ao grau de resistência da planta, sendo considerado como umas das principais respostas das plantas ao estresse hídrico. Neste mecanismo 
ocorre a biossíntese e o acúmulo de solutos compatíveis, no vacúolo ou no citosol, com função osmoprotetora, o que mantém o equilíbrio hídrico e preserva a integridade celular de proteínas, enzimas e membranas, impedindo a desidratação do citosol e proporcionando a manutenção das atividades vitais celulares (ABDUL JALEEL et al., 2007; CARLIN; SANTOS, 2009).

Diversas substâncias celulares possuem função osmoprotetora, as quais se destacam a trealose, a glicina betaína e a prolina. A prolina atua no ajuste osmótico de folhas sob baixo potencial hídrico e, principalmente, na estabilização de proteínas e na proteção das membranas contra os efeitos deletérios das espécies reativas de oxigênio, sendo considerada um osmólito-chave para as plantas sob estresses abióticos (SHARMA; DUBEY, 2005; KISHOR et al., 2005; GIANNAKOULA et al., 2008; MARIN; SANTOS, 2008). Nogueira et al. (2001) explicam que, de um modo geral, em muitas espécies, como arroz, sorgo, milho, trigo e cevada, a prolina livre está presente nas plantas em concentrações que variam entre 1 a $5 \mu \mathrm{mol} \mathrm{g}{ }^{-1}$ de massa fresca de folha e, devido à sua importância no ajustamento osmótico, é o composto mais estudado em plantas sob estresses abióticos (KISHOR et al., 2005). Na cultura da cana-de-açúcar, o acúmulo de prolina livre nas folhas tem relação com a maior resistência de cultivares à seca (INMAN-BAMBER; SMITH, 2005), podendo ser utilizada como indicadora do estresse hídrico (CARLIN; SANTOS, 2009).

A primeira linha de defesa das plantas por manter o status hídrico foliar é melhorar a eficiência do uso da água (EUA) através do fechamento estomático antecipado em plantas submetidas ao déficit hídrico (YORDANOV et al., 2000), o que pode impactar diretamente na eficiência fotossintética. No entanto, também pode ocorrer a abertura rápida dos estômatos quando a condição de água do solo volta a ser favorável. Pugnayre et al. (1993) explicam que essa expressiva redução a eficiência fotossintética das plantas, causada por uma situação de déficit hídrico, desencadeia uma seqüência de efeitos fisiológicos e morfológicos; os autores destacam que as alterações nos processos fisiológicos da planta ocorrem já no início da restrição hídrica, o que faz com que esta responda com os mecanismos de adaptação para tolerar a situação de estresse, proporcionando a otimização do uso da água.

O déficit hídrico também se caracteriza como um dos estresses ambientais responsáveis pala alterações dos pigmentos nas folhas, modificando a relação clorofila $a$ e $b$, a qual pode ser usada em plantas terrestres como indicativo de respostas para diagnosticar plantas sob condições de estresse hídrico (HENDRY; GRIME, 1993). Assim, métodos de quantificação e de estimativa de tais pigmentos, de certa forma, também podem ser utilizados como ferramentas para a seleção de genótipos tolerantes à seca (SILVA et al., 2007; CARLIN; SANTOS, 2009).

Diante do exposto, o presente trabalho teve como objetivo caracterizar fisiologicamente as variedades da cana-de-açúcar, submetidas a diferentes regimes hídricos. 


\subsection{MATERIAL E MÉTODOS}

O experimento foi conduzido entre abril de 2013 e abril de 2014, em uma área de 0,36 hectares, localizada na EMBRAPA Cerrados (CPAC), situada na BR 020, Km 18 (latitude 15³9'84', Sul e longitude 4744'41', Oeste), próxima à Região Administrativa de Planaltina-DF. A altitude da área é de aproximadamente $1014 \mathrm{~m}$ com temperatura e pluviosidade média anual de $21,9^{\circ} \mathrm{C}$ e $1.395,6 \mathrm{~mm}$, respectivamente.

O clima da região é classificado como tropical estacional (Aw), conforme Köppen (BRASIL, 1972), e é caracterizado por duas estações bem definidas: seca e chuvosa. Podem ocorrer de períodos de estiagem (veranicos) durante a estação chuvosa (SANO et al., 2008).

Os dados de precipitação pluviométrica, evapotranspiração de referência (ETo), temperatura máxima $\left({ }^{\circ} \mathrm{C}\right)$, temperatura mínima $\left({ }^{\circ} \mathrm{C}\right)$ e temperatura média durante a condução do experimento estão apresentados na Figura 1.

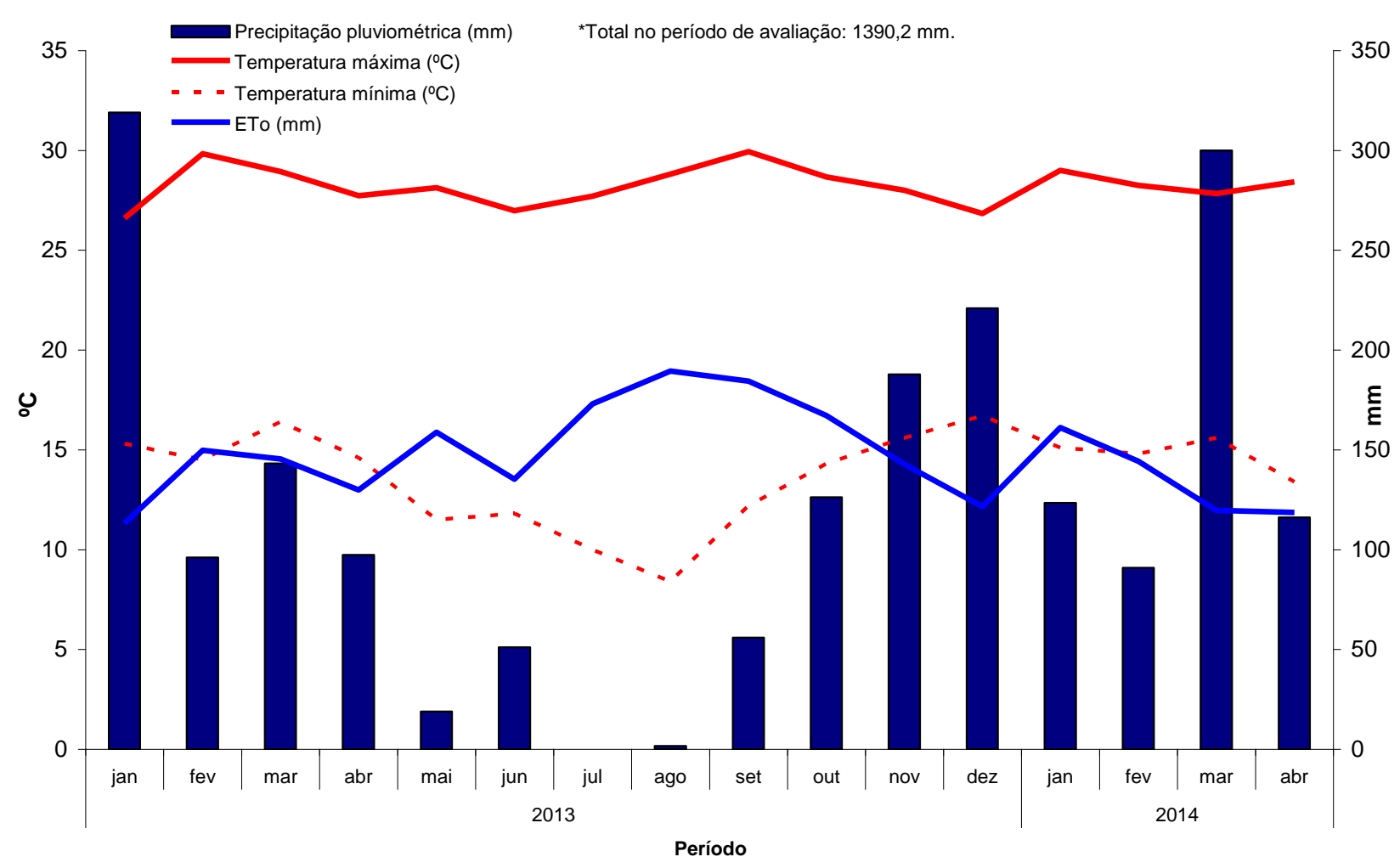

Figura 1. Precipitação pluviométrica, evapotranspiração de referência (ETo), temperatura máxima $\left({ }^{\circ} \mathrm{C}\right)$, temperatura mínima $\left({ }^{\circ} \mathrm{C}\right)$ da Região Administrativa de Planaltina-DF durante $\mathrm{o}$ período de 05/05/2013 a 24/04/2014. Dados coletados na Estação Meteorológica da Embrapa Cerrados, Planaltina-DF (2013).

O solo da área experimental é classificado como um Latossolo Vermelho Distrófico Típico, textura argilosa, A moderado (EMBRAPA, 2006) e sua caracterização química antes da instalação do experimento está apresentada na Tabela 1. 
Tabela 1. Caracterização química do solo da área de cultivo da cana-de-açúcar. Embrapa Cerrados, Planaltina-DF (2013).

\begin{tabular}{|c|c|c|c|c|c|c|c|c|}
\hline $\begin{array}{c}\text { Profundidade } \\
----\mathrm{cm} \text {---- }\end{array}$ & $\mathrm{pH} \mathrm{H} \mathrm{H}_{2} \mathrm{O}$ & $\begin{array}{c}\mathrm{Al} \\
--\mathrm{cmol}_{\mathrm{c}} \mathrm{dm}^{-3}-- \\
\end{array}$ & $\begin{array}{c}\mathrm{P} \\
----\mathrm{m}\end{array}$ & $\begin{array}{c}\mathrm{K} \\
\mathrm{n}^{-3}---- \\
\end{array}$ & $\mathrm{Ca}$ & $\begin{aligned} & \mathrm{Mg} \\
&= \mathrm{mol}_{\mathrm{c}} \mathrm{d} \\
&\end{aligned}$ & $\mathrm{H}+\mathrm{Al}$ & $\begin{array}{c}\text { MO } \\
---\%---\end{array}$ \\
\hline $0-20$ & 5,08 & 0,39 & 0,22 & 8,00 & 0,56 & 0,26 & 3,70 & 0,87 \\
\hline $20-40$ & 5,20 & 0,04 & 0,50 & 16,00 & 1,19 & 0,68 & 3,46 & 1,15 \\
\hline $40-60$ & 5,16 & 0,13 & 0,76 & 32,00 & 0,96 & 0,52 & 3,30 & 1,30 \\
\hline $60-80$ & 5,13 & 0,19 & 0,83 & 22,00 & 1,08 & 0,44 & 3,18 & 1,30 \\
\hline $80-100$ & 5,10 & 0,24 & 0,81 & 30,00 & 0,99 & 0,53 & 3,60 & 1,30 \\
\hline $100-120$ & 5,34 & 0,09 & 0,58 & 18,00 & 1,41 & 0,68 & 2,98 & 0,99 \\
\hline $120-140$ & 5,22 & 0,25 & 0,73 & 18,00 & 0,91 & 0,47 & 3,84 & 1,27 \\
\hline $140-160$ & 5,03 & 0,32 & 0,66 & 12,00 & 0,77 & 0,37 & 3,88 & 0,97 \\
\hline $160-180$ & 5,01 & 0,37 & 0,37 & 12,00 & 0,72 & 0,38 & 3,78 & 1,13 \\
\hline $180-200$ & 5,13 & 0,27 & 0,39 & 4,00 & 0,92 & 0,46 & 3,54 & 0,82 \\
\hline $200-220$ & 5,20 & 0,14 & 0,39 & 4,00 & 0,97 & 0,44 & 3,32 & 1,14 \\
\hline $220-240$ & 5,25 & 0,09 & 0,42 & 8,00 & 1,09 & 0,49 & 3,36 & 0,94 \\
\hline
\end{tabular}

$\mathrm{MO}=$ matéria orgânica

Foi realizada na área uma adubação corretiva (a lanço e incorporada) de $500 \mathrm{Kg} \mathrm{ha}^{-1} \mathrm{de}$ gesso e $50 \mathrm{~kg} \mathrm{ha}^{-1}$ de FTE BR-10 como fonte de micronutrientes ( $\mathrm{Zn}, \mathrm{B}, \mathrm{Cu}, \mathrm{Fe}, \mathrm{Mn}$ e Mo com 7,0, 2,5, 1,0, 4,0, 4,0 e 0,1\%, respectivamente) e em seguida a adubação de plantio foi feita na dose de $600 \mathrm{~kg} \mathrm{ha}^{-1}$ de NPK na formulação 04-30-16. O plantio da cana-de-açúcar foi realizado de forma manual em 18 de junho de 2010, sendo utilizadas três variedades, a RB855156, RB835486 ambas de maturação precoce e a RB867515 como variedade de referência por ser a mais plantada no Brasil (CAMARGO; VITTI, 2014).

A adubação de cobertura, aplicada de forma manual e após o primeiro corte das plantas, foi realizada em dois períodos, no início de maio na dose de $400 \mathrm{~kg} \mathrm{ha}^{-1}$ de NPK (formulação 2000-20) e em novembro de 2011 na dose de $600 \mathrm{~kg} \mathrm{ha}^{-1}$ de NPK (formulação 20-00-24), se repetindo nos anos posteriores.

Em maio de 2011 foi realizado o primeiro corte da cana-planta e após a nova brotação do canavial foi feito o segundo corte da cana-soca em abril de 2012; o terceiro corte da foi realizado em maio de 2013 e o quarto corte em abril de 2014. Aproximadamente, 20 a 30 dias após cada corte, foi feita uma irrigação de salvamento com uma lâmina de água de $60 \mathrm{~mm}$ devido à baixa precipitação neste período. As três variedades de cana-de-açúcar (RB855156, RB835486 e RB867515) foram submetidas a dois regimes hídricos: Irrigado (I) e Sequeiro (S).

O manejo da irrigação foi realizado com base na metodologia Penman-Monteith (MONTEITH, 1965), recomendado pela FAO (SMITH, 1991) e nos dados climatológicos, coletados nos meses de janeiro de 2013 a abril de 2014 na estação meteorológica localizada a 100m do experimento. $\mathrm{Na}$ área experimental, a irrigação foi realizada conforme o sistema Line Source Sprinkler System, descrito por Hanks et al. (1976), e modificado para aplicação na forma de barras 
lineares acopladas a um carretel (Figura 2), em que a lâmina de água aplicada na cultura descresse do centro para as extremidades da área.

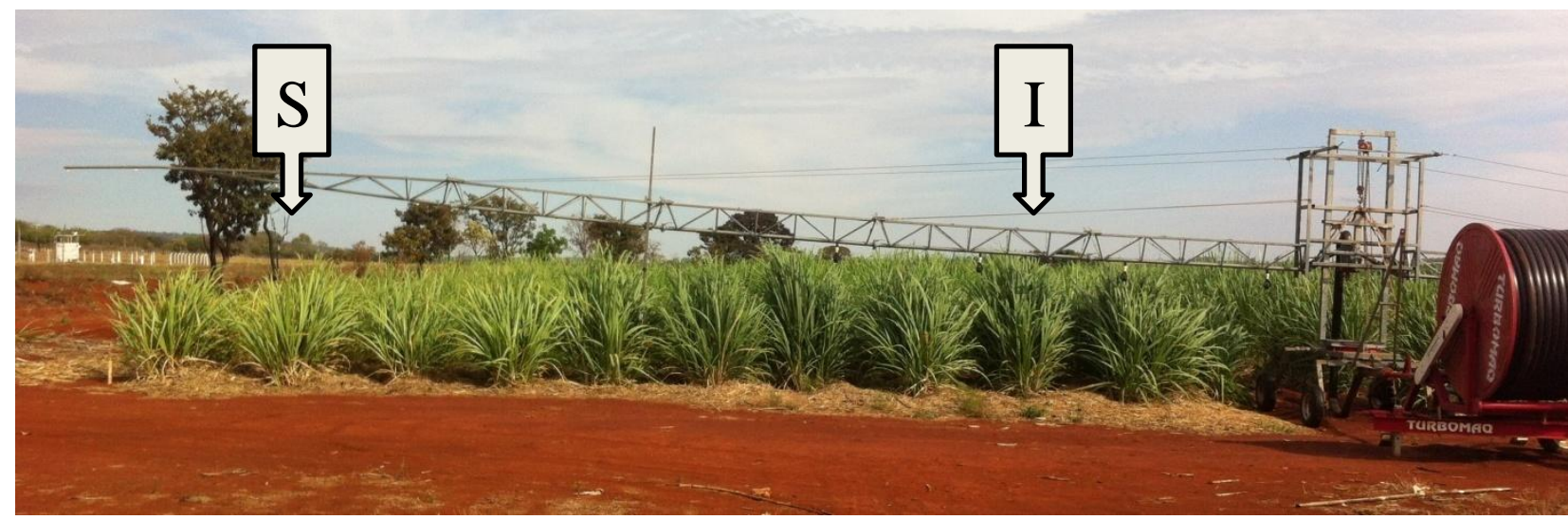

Figura 2. Sistema Line Source Sprinkler System, mostrando as parcelas experimentais: sequeiro (S) e irrigada (I). Embrapa Cerrados, Planaltina-DF (2013).

O experimento foi conduzido em um delineamento em blocos ao acaso com três repetições em parcelas subdivididas no tempo, com três variedades: RB855156, RB835486 e RB867515 (parcela), ausência e presença da irrigação (irrigado e sequeiro - subparcela) e seis coletas de dados no tempo (100, 150, 200 e 250 dias após o corte - DAC) que foram as subsubparcelas. Cada parcela foi composta por uma fileira de plantas com 4,0 $\mathrm{m}$ de comprimento e 1,5 m de largura, sendo a área útil formada pelos 3,0 m centrais da mesma, descartando-se 0,5 $\mathrm{m}$ de cada lado para evitar o efeito da bordadura.

Para o tratamento irrigado, as parcelas foram irrigadas em turno de rega fixo com intervalos de 9 dias, e receberam lâminas de irrigação que corresponderam a 100\% da evapotranspiração da cultura (ETc), estimada através do balanço climatológico, utilizando-se a irrigação via sistema autopropelido com barra irrigadora com bocais conjugados e emissores XIWobbler (Figura 2).

Para o tratamento de sequeiro o suprimento hídrico foi completamente suspenso após a irrigação de salvamento, na tentativa de reproduzir a realidade dos sistemas de produção de algumas usinas da região Centro-Oeste, que tem canaviais implantados em áreas sob longos períodos de deficiência hídrica devido à estacionalidade pluviométrica (Figura 2).

Para os diferentes parâmetros analisados, cinco plantas de cada variedade foram utilizadas de forma aleatória na área útil da parcela, utilizando-se a folha +3 , de acordo com o sistema de Kuijper (DILLEWIJN, 1952), por ser completamente desenvolvida do ponto de vista fisiológico e totalmente desenrolada morfologicamente. Foram avaliados os seguintes parâmetros fisiológicos: Prolina livre na folha $\left(\mu \mathrm{mol} \mathrm{g} \mathrm{g}^{-1} \mathrm{MF}\right.$ - matéria fresca); E - transpiração $\left(\mathrm{mmol} \mathrm{H}_{2} \mathrm{O} \mathrm{m}^{-2}\right.$ $\left.\mathrm{s}^{-1}\right) ; \mathrm{g}_{\mathrm{s}}$ - condutância estomática $\left(\mathrm{mol} \mathrm{H}_{2} \mathrm{O} \mathrm{m} \mathrm{m}^{-2}\right) ; \mathrm{A}$ - fotossíntese líquida $\left(\mu \mathrm{mol} \mathrm{CO}_{2} \mathrm{~m}^{-2} \mathrm{~s}^{-1}\right) ; \mathrm{Ci}$ - 
carbono intracelular $\left(\mu \mathrm{mol} \mathrm{CO} \mathrm{CO}^{-2} \mathrm{~s}^{-1}\right)$; EUA - eficiência instantânea do uso da água ( $\mathrm{A} \mathrm{E}^{-1}, \mu \mathrm{mol}$ $\left.\mathrm{mmol}^{-1}\right)$; EIUA - eficiência intrinseca do uso de água $\left(\mathrm{A} \mathrm{g}_{\mathrm{s}}^{-1}, \mu \mathrm{mol} \mathrm{mol}^{-1}\right)$; EC - eficiência da carboxilação ( $\mathrm{A} \mathrm{Ci}^{-1}, \mu \mathrm{mol} \mathrm{m} \mathrm{m}^{-2} \mathrm{~Pa}$ ); Clo $a$ - clorofila tipo $a$ (índice de clorofila falker, ICF); Clo $b$ - clorofila $b$ (ICF); Clo $a+b$ - clorofila total (ICF).

Os parâmetros de trocas gasosas analisados foram avaliados aos 100 DAC, quando as plantas estavam no pico do período de restrição hídrica na região do presente estudo. As avaliações foram realizadas no período da manhã (entre 8:00 e 11:00 horas). Para tanto, foi utilizado o medidor de trocas gasosas IRGA (Marca ADC, Modelo LC Pro S/ 32662). Foram obtidos os dados de: fotossíntese liquida (A, $\mu \mathrm{mol} \mathrm{m} \mathrm{m}^{-2} \mathrm{~s}^{-1}$ ), condutância estomática (Gs, mol m $\mathrm{m}^{-2} \mathrm{~s}^{-1}$ ), transpiração foliar (E, mmol $\left.\mathrm{H} 2 \mathrm{O} \mathrm{m}^{-2} \mathrm{~s}^{-1}\right)$, concentração intracelular de $\mathrm{CO}_{2}\left(\mathrm{Ci}, \mu \mathrm{mol} \mathrm{CO} 2 \mathrm{~mol}^{-1}\right)$, e também foi calculada a eficiência no uso da água $\left(\mathrm{EUA}=\mathrm{A} \mathrm{E}^{-1}\right)$. EIUA - eficiência intrinseca do uso de água $\left(\mathrm{A} \mathrm{g}_{\mathrm{s}}^{-1}, \mu \mathrm{mol} \mathrm{mol}{ }^{-1}\right)$; EC - eficiência da carboxilação $\left(\mathrm{A} \mathrm{Ci}^{-1}, \mu \mathrm{mol} \mathrm{m} \mathrm{m}^{-2} \mathrm{~Pa}\right)$.

A avaliação dos teores de prolina livre nas folhas foi feita aos 100, 150, 200 e 250 dias após o corte da cana-de-açúcar. Pesou-se pesou-se $0,5 \mathrm{~g}$ de folhas que foram maceradas em almofariz com $10 \mathrm{~mL}$ de ácido sulfossalicílico a $3 \%$ e filtrado em papel Whatman $\mathrm{n}^{\mathrm{o}} 2$. Do filtrado foi retirada uma alíquota de $150 \mu \mathrm{l}$, adicionados $2,8 \mathrm{ml}$ de água, $2 \mathrm{ml}$ de ninidrina, $2 \mathrm{ml}$ de ácido acético glacial, $0,1 \mathrm{ml}$ de glicina da solução de $126 \mathrm{mM}$. A mistura foi mantida em banho-maria à $100{ }^{\circ} \mathrm{C}$ por uma hora para desenvolvimento da cor. Em seguida, os tubos de ensaio foram colocados em banho de gelo por 10 minutos para de cessar a reação. Foram adicionados $4 \mathrm{~mL}$ de tolueno à mistura de reação, com agitação vigorosa por 20 segundos. Logo após o repouso e formação da mistura bifásica, a extração do cromóforo contendo tolueno (fase rósea superior) foi feita com pipeta de plástico e colocado diretamente na cubeta do espectrofotômetro. As leituras foram feitas no comprimento de ondas de $520 \mathrm{nM}$, utilizando-se o tolueno como branco. Utilizou-se como padrão a prolina pura e os resultados foram expressos em $\mu \mathrm{mol} \mathrm{g}{ }^{-1} \mathrm{MF}$. Cada repetição (amostra) foi representada por um extrato simples feito em triplicata (BATES et al., 1973).

$\mathrm{O}$ teor de prolina livre foi calculado pela equação: [( $\mu \mathrm{g}$ prolina livre/mL $\mathrm{x} \mathrm{mL}$ tolueno $) / 115,5 \mu \mathrm{g} / \mu \mathrm{mole}] /[(\mathrm{g}$ amostra $) / 5]=\mu$ moles de prolina livre $\mathrm{g}^{-1}$ de massa fresca.

Os índices de clorofilas $a, b$ e total foram determinados no mesmo período dos parâmetros fotossintéticos, com o auxílio de um medidor portátil de clorofila, ClorofiLOG (Falker, CFL-1030), sendo posicionado no terço médio da folha +3 , fazendo-se seis leituras por folha nas cinco plantas avaliadas de cada parcela, evitando-se a nervura central. Para cada avaliação, foi calculada a média aritmética das seis leituras por folha. Os dados foram submetidos à análise de Normalidade pelo teste Shapiro-Wilk, analisando-se a significância a 5\%; análise de Homocedase a significância a 5\%, pelo teste de Levene para verificar possíveis heterocedasticidade dos erros; e a Independência dos dados pelo teste de Durbin-Watson. Em seguida os dados foram submetidos à 
análise de variância e regressão polinomial pelo teste $\mathrm{F}$ a $5 \%$ de probabilidade, e as médias comparadas pelo teste Tukey a 5\% de probabilidade. 


\subsection{RESULTADOS E DISCUSSÃO}

De acordo com o resumo da análise de variância (Tabela 2) verificou-se que houve efeito significativo da interação dos tratamentos variedades $\mathrm{x}$ irrigação $\mathrm{x}$ dias após o corte (DAC) para a concentração de prolina livre na folha +3 das variedades de cana-de-açúcar avaliadas. Para o efeito dos parâmetros de trocas gasosas, houve interação variedades x irrigação somente para a EIUA, e o efeito isolado dos tratamentos, sendo que para a transpiração (E), condutância estomática $\left(\mathrm{g}_{\mathrm{s}}\right)$, fotossíntese líquida $(\mathrm{A})$ e a eficiência da carboxilação $(\mathrm{EC})$ responderam significativamente à irrigação, e somente $\mathrm{E}$ e $\mathrm{g}_{\mathrm{s}}$ para o efeito das variedades testadas. As plantas de cana-de-açúcar não apresentaram diferença significativa para a eficiência do uso da água (EUA) e o carbono intracelular (Ci). Nos teores de clorofila na folha só foi constatado o efeito isolado dos tratamentos, sendo que para a clorofila $b$ não houve resposta significativa para o uso da irrigação.

Tabela 2. Resumos da análise de variâncias dos parâmetros fisiológicos: E, gs, A, Ci, EUA, EIUA, EC, Clo $a$, Clo $b$, Clo $a+b$ na folha +3 das variedades RB835486, RB855156 e RB867515 de cana-de-açúcar cultivadas com irrigação equivalente a $100 \%$ da ETc.

\begin{tabular}{|c|c|c|c|c|c|c|c|c|c|c|c|c|}
\hline \multirow{2}{*}{ FV } & \multirow{2}{*}{ GL } & \multicolumn{11}{|c|}{ Quadrado médio } \\
\hline & & Prolina & E & $\mathrm{g}_{\mathrm{s}}$ & A & $\mathrm{Ci}$ & EUA & EIUA & EC & Clo $a$ & Clo $b$ & Clo $a+b$ \\
\hline Bloco & 3 & $0,001^{\mathrm{ns}}$ & $0,25^{\mathrm{ns}}$ & $0,0008^{\text {ns }}$ & $3,00^{\mathrm{ns}}$ & $26,18^{\text {ns }}$ & $2,30 *$ & $7884,03 \mathrm{~ns}$ & $0,0002^{\mathrm{ns}}$ & $0,83^{\mathrm{ns}}$ & $5,91^{\mathrm{ns}}$ & $11,11^{\mathrm{ns}}$ \\
\hline Variedade (V) & 2 & $0,045^{* *}$ & $3,50 *$ & $0,0062 *$ & $42,28^{\mathrm{ns}}$ & $1110,66^{\mathrm{ns}}$ & $0,10 \mathrm{~ns}$ & $460742,26^{*}$ & $0,0058^{\mathrm{ns}}$ & $49,82 * *$ & $45,12 * *$ & $171,94 * *$ \\
\hline Resíduo a & 6 & 0,002 & 0,68 & 0,0010 & 11,21 & 670,02 & 0,28 & 68425,45 & 0,0019 & 3,22 & 3,47 & 12,21 \\
\hline Irrigação ( I ) & 1 & $6,490 * *$ & $36,93 * *$ & $0,1717 * *$ & $622,91 * *$ & $645,33^{\mathrm{ns}}$ & $0,99 \mathrm{~ns}$ & $2231087,46 * *$ & $0,0241 * *$ & $8,06^{* *}$ & $0,48^{\mathrm{ns}}$ & $12,43^{*}$ \\
\hline V x I & 2 & $0,068 * *$ & $1,00^{\mathrm{ns}}$ & $0,002^{\mathrm{ns}}$ & $5,31^{\mathrm{ns}}$ & $696,92^{\mathrm{ns}}$ & $0,03 \mathrm{~ns}$ & $263472,71^{* *}$ & $0,0012^{\mathrm{ns}}$ & $0,63^{\mathrm{ns}}$ & $1,63^{\mathrm{ns}}$ & $2,83^{\mathrm{ns}}$ \\
\hline Resíduo b & 9 & 0,004 & 0,82 & 0,0012 & 2,99 & 195,32 & 0,21 & 7878,42 & 0,0005 & 0,40 & 1,42 & 2,28 \\
\hline DAC (D) & 3 & $2,483^{* *}$ & - & - & - & - & - & - & - & - & - & - \\
\hline V x D & 6 & $0,158 * *$ & - & - & - & - & - & - & - & - & - & - \\
\hline I x D & 3 & $1,906^{* *}$ & - & - & - & - & - & - & - & - & - & - \\
\hline V x I x D & 6 & $0,269 * *$ & - & - & - & - & - & - & - & - & - & - \\
\hline Resíduo c & 54 & 0,004 & - & - & - & - & - & - & - & - & - & - \\
\hline Média & & 0,52 & 5,55 & 0,21 & 18,90 & 137,70 & 3,48 & 799,51 & 0,14 & 40,62 & 13,07 & 53,69 \\
\hline CV1 (\%) & & 8,05 & 14,84 & 14,59 & 17,71 & 18,80 & 15,15 & 32,72 & 31,00 & 4,42 & 14,24 & 6,51 \\
\hline CV2 (\%) & & 11,35 & 16,36 & 16,45 & 9,15 & 10,15 & 13,17 & 11,10 & 16,51 & 1,55 & 9,11 & 2,81 \\
\hline VC3 (\%) & & 12,59 & - & - & - & - & - & - & - & - & - & - \\
\hline
\end{tabular}

FV: fonte de variação; GL: grau de liberdade; CV: coeficiente de variação; c: colmo; ns: não significativo; $*$ e $* *$ : respectivamente significativo para $\mathrm{p}<0,05$ e $\mathrm{p}<0,01$; Prolina livre na folha $\left(\mu \mathrm{mol} \mathrm{g}^{-1} \mathrm{MF}\right) ; \mathrm{E}-\operatorname{transpiração~}\left(\mathrm{mmol} \mathrm{H}_{2} \mathrm{O}\right.$ $\left.\mathrm{m}^{-2} \mathrm{~s}^{-1}\right) ; \mathrm{g}_{\mathrm{s}}$ - condutância estomática $\left(\mathrm{mol} \mathrm{H} \mathrm{O} \mathrm{m}^{-2} \mathrm{~s}^{-1}\right) ; \mathrm{A}$ - fotossíntese líquida $\left(\mu \mathrm{mol} \mathrm{CO}_{2} \mathrm{~m}^{-2} \mathrm{~s}^{-1}\right) ; \mathrm{Ci}^{-} \mathrm{carbono}$ intracelular ( $\left.\mu \mathrm{mol} \mathrm{CO} \mathrm{Cm}^{-2} \mathrm{~s}^{-1}\right)$; EUA - eficiência instantânea do uso da água $\left(\mathrm{A} \mathrm{E}^{-1}, \mu \mathrm{mol} \mathrm{mmol}{ }^{-1}\right)$; EIUA - eficiência intrinseca do uso de água $\left(\mathrm{A} \mathrm{g}_{\mathrm{s}}^{-1}, \mu \mathrm{mol} \mathrm{mol}{ }^{-1}\right)$; EC - eficiência da carboxilação ( $\mathrm{A} \mathrm{Ci}^{-1}, \mu \mathrm{mol} \mathrm{m}^{-2} \mathrm{~s}^{-1} \mathrm{~Pa}$ ); $\mathrm{Clo}^{a}$ clorofila tipo $a$ (índice de clorofila falker, ICF); Clo $b$ - clorofila $b$ (ICF); Clo $a+b$ - clorofila total (ICF).

Nos tratamentos em sistema irrigado, os teores foliares de prolina apresentaram pequenas alterações e se ajustaram significativamente em um modelo quadrático, onde aos 100 DAC os teores foliares de prolina livre eram de $0,17,0,29$ e $0,43 \mu \mathrm{mol} \mathrm{g}^{-1} \mathrm{MF}$ nas folhas das variedades RB855156, RB867515 e RB835486, respectivamente. Estes valores apresentaram uma redução após o início do período chuvoso, que ocorreu por volta dos 137 dias, atingindo concentrações mínimas aos 139,88, 188,76 e 171,61DAC com 0,13,0,14 e 0,17 $\mu$ mol g ${ }^{-1} \mathrm{MF}$, respectivamente para as mesmas variedades. Em seguida, os valores voltaram a subir, porém chegando aos 250 DAC com teores semelhantes aos registrados no início do ciclo, exceto para a RB855156 que ficou com 52,94\% maior que no início do ciclo. No entanto, nenhuma das variedades ultrapassou a concentração de $0,5 \mu \mathrm{mol} \mathrm{g}{ }^{-1} \mathrm{MF}$ durante o período avaliado, ficando entre 
1 e $5 \mu \mathrm{mol} \mathrm{g}{ }^{-1} \mathrm{MF}$, conforme proposto por Nogueira et al. (2001) como concentração foliar de prolina considerada normal para a maiorias das espécies vegetais (Figura 3A).

IRRIGADO

(A)

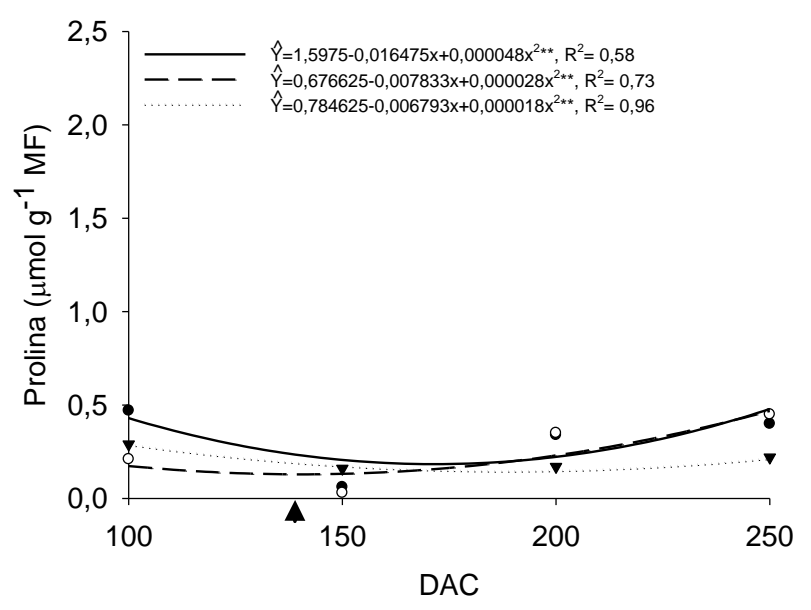

SEQUEIRO

(B)

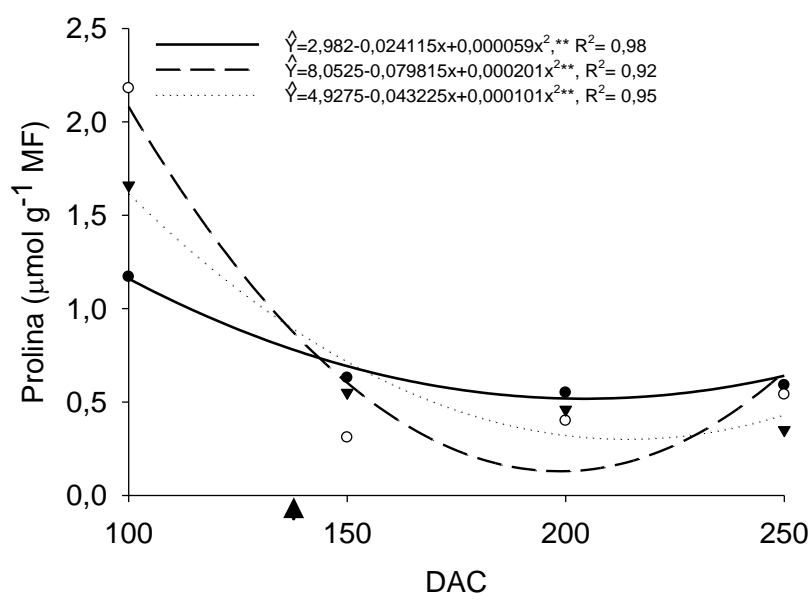

Figura 3. Teor de prolina livre na folha +3 das variedades RB835486 ( $-\bullet)$, RB855156 (-----O) e RB867515 (...... $)$ ) cultivadas em sistema irrigado (100\% da ETc) e em sequeiro (0\% da ETc), aos 100, 150, 200 e 250 dias após o corte (DAC). ( $\mathbf{\Delta}$ ) - início do período chuvoso.

Nas folhas das plantas cultivadas em sistema de sequeiro (0\% da ETc), todas as variedades apresentaram teores elevados de prolina livre aos $100 \mathrm{DAC}$, sendo que a variedade RB855156 foi a com maior quantidade de prolina por grama de massa fresca, apresentando valores de 2,07 $\mu \mathrm{mol} \mathrm{g}^{-1} \mathrm{MF}$, equivalente a $1117,65 \%$ maior que nas plantas da mesma variedade no mesmo período que receberam a irrigação de $100 \%$ da ETc. A variedade RB867515 foi a que apresentou a segunda maior concentração de prolina livre na folha quando cultivada em sequeiro, com 1,61 $\mu \mathrm{mol} \mathrm{g}{ }^{-1} \mathrm{MF}$, com um incremento de $455,17 \%$ superior às plantas da mesma variedade em sistema irrigado. A variedade RB835486 foi a que apresentou menor concentração de prolina livre em sequeiro, e também a menor diferença para o tratamento irrigado, com $1,16 \mu \mathrm{mol} \mathrm{g}^{-1} \mathrm{MF}$ ou $169,77 \%$ a mais que no tratamento irrigado. No entanto, para todas as variedades avaliadas, esses valores decresceram rapidamente com o início do período chuvoso (137 DAC), reduzindo abruptamente os valores de prolina livre na folha, atingindo o mínimo de 0,12 (RB855156), 0,30 (RB867515) e 0,52 $\mu \mathrm{mol} \mathrm{g}{ }^{-1} \mathrm{MF}$ (RB835486). Porém, durante o período chuvoso, observou-se que as concentrações foliares de prolina voltaram a aumentar, chegando aos 250DAC com o equivalente a 0,64, 0,66 e 0,43 $\mu \mathrm{mol} \mathrm{g}{ }^{-1} \mathrm{MF}$ (RB835486, RB855156 e RB867515, respectivamente) com incrementos de 33,33\% (RB835486), 153,85\% (RB855156) e 104,76\% (RB867515), quando comparado com as plantas da mesma idade em regime de sequeiro, sendo apenas a RB867515 ficou abaixo de $0,5 \mu \mathrm{mol} \mathrm{g}^{-1} \mathrm{MF}$.

Os dados do presente trabalho corroboram com os obtidos por Carlin e Santos (2009), quando avaliaram indicadores fisiológicos da interação entre déficit hídrico e acidez do solo em 
cana-de-açúcar; os autores verificaram que a concentração de prolina intensificou-se com o estresse hídrico. Por outro lado, os resultados obtidos no presente trabalho foram superiores aos 3,4 $\mu_{\mathrm{mol} \mathrm{g}}{ }^{-1}$ MF observados por Queiroz et al. (2008) quando estudaram osmoprotetores em cana-de-açúcar sob efeito da disponibilidade hídrica no solo, verificando que os níveis de prolina livre na folha aumentaram concomitantemente com o aumento da restrição hídrica para as plantas. Bidóia et al. (2006) verificaram um aumento de aproximadamente 151,3\% no acúmulo de prolina em plantas de cana-de-açúcar, com o aumento da deficiência hídrica no solo. Estes resultados para a concentração de prolina livre na folha sugerem que esse acúmulo de prolina tem relação com a maior resistência de cultivares de cana-de-açúcar à seca, pois no ajuste osmótico de folhas com baixo potencial hídrico, a prolina se acumula como soluto compatível para estabilizar as membranas celulares e manter a conformação de proteínas, o que impede a desidratação do citosol, como porposto por KISHOR et al. (2005) e Inman-Bamber e Smith (2005).

Foi verificado um leve aumento da prolina livre registrado após os 150DAC para a variedade RB835486 e RB855156, podendo ter sido ocasionado um estresse abiótico relacionado ao excesso hídrico, o que pode prejudicar o desenvolvimento da de algumas culturas, como observado por Bortolo et al. (2009) para a Calendula officinalis L., Pizard et al. (2006) para Matricaria chamomilla L., e Silva et al. (2002) para Melaleuca alternifolia. Isto provavelmente ocorreu devido ao excesso diário de água no solo durante o período chuvoso da Região, o qual pode ter causado redução imediata na troca de gases entre a planta e o ambiente, reduzindo o suprimento de oxigênio às raízes e desta forma limitando a respiração, a absorção de nutrientes e outras funções das mesmas (PARDOS, 2004). Também foi verificado que, após o início das chuvas, as concentrações de prolina foram sempre maiores para a variedade RB835486, o que pode ter sido em resposta ao ataque de fungos, sendo observada a incidência da podridão vermelha, causada pelo agente etiológico Colletotrichum falcatum, tendo a parte da área foliar atacada pelo fungo com aumento que coincidiu com do uso da irrigação (100\% da ETc), como também concomitante ao início da estação chuvosa, o que serve como indicativo da sua pouca adaptação para a Região Centro-Oeste, pela susceptibilidade ao ataque de fungos em altitudes elevadas (DAROS et al., 2010). Souza et al. (2004) sugeriram que o pequeno acúmulo de prolina pode ser visto como um indicativo de alterações metabólicas devido ao estresse e não como uma resposta adaptativa com efeitos protetores para a planta, podendo indicar alguma injúria às plantas.

De acordo com a Tabela 3, a variedade BR867515 foi a que apresentou maior taxa de transpiração (E) e condutância estomática $\left(\mathrm{g}_{\mathrm{s}}\right)$ comparado as demais variedades. A transpiração foi $10,91 \%$ superior à da variedade RB855156 e 27,05\% da RB835486; e $\mathrm{g}_{\mathrm{s}}$ 14,29\% e 26,32\% superior às mesmas variedades respectivamente. No entanto, não diferenciou significativamente da RB855156 para estes parâmetros. 
Tabela 3. Médias dos parâmetros fisiológicos: E, gs, A, Ci, EUA, EC, Clo $a$, Clo $b$, Clo $a+b$ na folha +3 das variedades RB835486, RB855156 e RB867515 de cana-de-açúcar cultivadas em sistema irrigado (100\% da ETc) e em sequeiro (0\% da ETc).

\begin{tabular}{lcccccccccc}
\hline \multirow{2}{*}{ Tratamentos } & & \multicolumn{7}{c}{ Quadrado médio das características fisiológicas avaliadas } \\
\cline { 3 - 10 } & & $\mathrm{E}$ & $\mathrm{g}_{\mathrm{s}}$ & $\mathrm{A}$ & $\mathrm{Ci}$ & EUA & $\mathrm{EC}$ & Clo $a$ & Clo $b$ & Clo $a+b$ \\
\hline Variedades & $\mathrm{RB} 845486$ & $4,88 \mathrm{~b}$ & $0,19 \mathrm{~b}$ & $16,59 \mathrm{a}$ & $150,33 \mathrm{a}$ & $3,40 \mathrm{a}$ & $0,11 \mathrm{a}$ & $37,91 \mathrm{c}$ & $10,44 \mathrm{~b}$ & $48,35 \mathrm{~b}$ \\
& $\mathrm{RB} 855156$ & $5,59 \mathrm{ab}$ & $0,21 \mathrm{ab}$ & $18,92 \mathrm{a}$ & $135,77 \mathrm{a}$ & $3,38 \mathrm{a}$ & $0,14 \mathrm{a}$ & $42,81 \mathrm{a}$ & $13,73 \mathrm{a}$ & $56,54 \mathrm{a}$ \\
& $\mathrm{RB} 867515$ & $6,20 \mathrm{a}$ & $0,24 \mathrm{a}$ & $21,19 \mathrm{a}$ & $127,00 \mathrm{a}$ & $3,42 \mathrm{a}$ & $0,17 \mathrm{a}$ & $41,15 \mathrm{a}$ & $15,05 \mathrm{a}$ & $56,20 \mathrm{a}$ \\
\hline Irrigação & $\mathrm{I}$ & $6,79 \mathrm{a}$ & $0,30 \mathrm{a}$ & $24,00 \mathrm{a}$ & $142,88 \mathrm{a}$ & $3,53 \mathrm{a}$ & $0,17 \mathrm{a}$ & $41,20 \mathrm{a}$ & $13,21 \mathrm{a}$ & $54,41 \mathrm{a}$ \\
& $\mathrm{S}$ & $4,31 \mathrm{~b}$ & $0,13 \mathrm{~b}$ & $13,81 \mathrm{~b}$ & $132,51 \mathrm{a}$ & $3,20 \mathrm{a}$ & $0,10 \mathrm{~b}$ & $40,04 \mathrm{~b}$ & $12,93 \mathrm{a}$ & $52,98 \mathrm{~b}$ \\
\hline
\end{tabular}

Médias seguidas de mesma letra minúsculas na coluna, não diferem entre si por Tukey para $\mathrm{p}<0,05$; FV: fonte de variação; GL: grau de liberdade; CV: coeficiente de variação; c: colmo; ns: não significativo; * e **: respectivamente significativo para $\mathrm{p}<0,05 \mathrm{e} \mathrm{p}<0,01 ; \mathrm{E}$ - transpiração $\left(\mathrm{mmol} \mathrm{H}_{2} \mathrm{O} \mathrm{m}^{-2} \mathrm{~s}^{-1}\right) ; \mathrm{g}_{\mathrm{s}}$ - condutância estomática $\left(\mathrm{mol} \mathrm{H}_{2} \mathrm{O} \mathrm{m}^{-2} \mathrm{~s}^{-1}\right)$; A - fotossíntese líquida $\left(\mu \mathrm{mol} \mathrm{CO} \mathrm{Cm}^{-2} \mathrm{~s}^{-1}\right) ; \mathrm{Ci}$ - carbono intracelular $\left(\mu \mathrm{mol} \mathrm{CO}_{2} \mathrm{~m}^{-2} \mathrm{~s}^{-1}\right)$; EUA - eficiência instantânea do uso da água ( $\left.\mathrm{A} \mathrm{E}^{-1}\right)$; $\mathrm{EC}$ - eficiência da carboxilação $\left(\mathrm{A} \mathrm{Ci}^{-1}\right)$; Clo $a$ - clorofila tipo $a$ (índice de clorofila falker, ICF); Clo $b$ - clorofila $b$ (ICF); Clo $a+b$ - clorofila total.

A variedade RB835486 foi a variedade que apresentou os menores resultados para os parâmetros supracitados. A mesma tendência se repete para os resultados das concentrações de clorofilas na folha, sendo esta variedade a que teve os menores valores, com redução de $8,55 \%$ e $12,93 \%$ para a clorofila $a$ (Clo $a$ ), $44,16 \%$ e $31,51 \%$ para a clorofila $b$ (Clo b) e $16,24 \%$ e $16,94 \%$ para a clorofila total (Clo $a+b)$, comparado com as variedades RB867515 e RB855156, respectivamente (Tabela 3). Ainda de acordo com a mesma tabela, pode ser observado que para o efeito isolado da irrigação, as plantas que receberam irrigação apresentaram respostas superiores para transpiração $(\mathrm{E})$, condutância estomática $\left(\mathrm{g}_{\mathrm{s}}\right)$, fotossíntese líquida $(\mathrm{A})$, eficiência da carboxilação (EC), clorofila $a$ (Clo $a$ ) e clorofila total (Clo $a+b$ ), tendo incremento de 57,54\%, $138 \%, 73,79 \%, 54,55 \%, 2,90 \%$ e $29,70 \%$ para estes parâmetros, respectivamente. Porém, não foi observada diferença estatística para o carbono intracelular (Ci), eficiência do uso da água (EUA) e a clorofila $b(\mathrm{Clo} b)$.

$\mathrm{Na}$ interação entre variedades $\mathrm{x}$ irrigação, observou-se que para a eficiência intrínseca do uso da água (EIUA), as variedades não diferenciaram entre si quando cultivadas sob irrigação. No entanto, quando cultivadas em regime de sequeiro, as variedades diferenciaram estatisticamente entre si e entre os diferentes regimes hídricos avaliados. Na comparação do mesmo parâmetro entre as variedades avaliadas, a variedade BR867515 foi a que apresentou menor eficiência intrínseca do uso da água, sendo 24,01\% menor que a RB855156, e 102,65\% inferior a que a RB835486, sendo esta última a que apresentou os maiores valores. A variedade RB835486 quando cultivada em sequeiro foi a que apresentou maior acréscimo da EIUA $(189,03 \%)$ comparada com o cultivo da mesma variedade sob irrigação. A RB867515 foi a que apresentou aumento intermediário para o mesmo parâmetro, com 95,74\% a mais que as plantas em cultivo irrigado, e a RB855156 foi que menos alterou a sua EIUA, com aumento equivalente a 77,74\% comparado ao tratamento irrigado (Figura 4). 


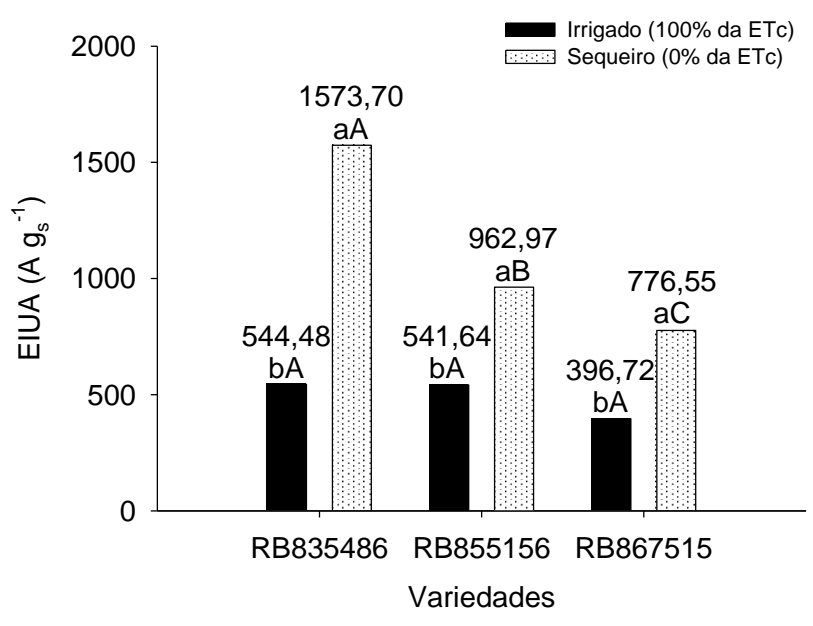

Figura 4. Eficiência intrínseca do uso da água (EIUA, $\mathrm{A} \mathrm{g}_{\mathrm{s}}{ }^{-1}$ ) na folha +3 das variedades RB835486, RB855156 e RB867515 cultivadas em sistema irrigado (100\% da ETc) e em sequeiro (0\% da ETc), aos 100 dias após o corte (DAC). Médias seguidas de mesma letra minúsculas na mesma variedade, e maiúsculas entre variedades diferentes não diferem entre si na mesma linha por Tukey para $\mathrm{p}<0,05$.

Machado et al. (2009) também não observaram diferenças significativas entre variedades de cana-de-açúcar para EC e EIUA. No entanto, os autores afirmaram que houve a redução dos valores de EIUA em razão do déficit hídrico nas fases de crescimento e de maturação do colmo.

Semelhante ao observado por Gonçalves et al. (2010) em variedades de cana-de-açúcar submetidas à deficiência hídrica, ocorreu redução nas variáveis de trocas gasosas $\left(\mathrm{E}, \mathrm{g}_{\mathrm{s}} \mathrm{e} \mathrm{A}\right)$, assim como na eficiência do uso da água na produtividade (EUAp), mas as reduções mais acentuadas ocorreram nas plantas submetidas ao tratamento sob estresse hídrico severo. Esses resultados confirmam que, sob estresse severo, uma das primeiras respostas para impedir a desidratação excessiva das folhas das variedades testadas é o fechamento estomático e o conseqüente declínio na fotossíntese líquida, tendo efeitos protetores contra a seca por manter o status hídrico das plantas, e de forma a minimizar a perda de água e aumentar a eficiência no uso da água (CHAVES et al., 2008; INMAN-BAMBER; SMITH, 2005; INMAN-BAMBER et al., 2008), sendo, portanto, considerado como um mecanismo de resistência à seca. Outro aspecto importante é redução na transpiração (E) em condição de déficit hídrico, o que também é em consequiência da diminuição na $\mathrm{g}_{\mathrm{s}}$, reduzindo o uso da água, o que segundo Machado et al. (2009) pode-se considerar como uma estratégia bem-sucedida nos genótipos em resposta à restrição hídrica. Ferraz et al. (2012) explicaram que, de modo geral, as plantas sob estresse hídrico tendem a adotar um mecanismo conservativo, reduzindo a $g_{s}$ e a $E$ e aumentando a EUA, fazendo com que nessas condições, a taxa de fotossíntese também seja reduzida. 
Estes resultados corroboram com os relatados por Smit e Singels (2006) que notaram redução na condutância estomática em duas variedades de cana-de-açúcar, afirmando que tal variável apresenta maior sensibilidade que o potencial hídrico à medida que o solo se torna mais seco. Da mesma forma, Gonçalves et al. (2010) também observaram que houve redução na transpiração foliar em quatro variedades de cana-de-açúcar submetidas ao déficit hídrico, apresentando respostas diferenciadas entre elas.

Para a fotossíntese líquida (A), observou-se que os valores obtidos foram semelhantes aos encontrados por Gonçalves et al. (2010); os autores verificaram que sob condições em que não houve limitação hídrica, a fotossíntese líquida permaneceu entre 19 e $24 \mu \mathrm{mol} \mathrm{CO}_{2} \mathrm{~m}^{-2} \mathrm{~s}^{-1}$. Entretanto, os autores afirmaram que a fotossíntese decresceu até o estresse hídrico severo, em que as taxas de assimilação líquida de $\mathrm{CO}_{2}$ atingiram valores inferiores a $5 \mu \mathrm{mol} \mathrm{CO}_{2} \mathrm{~m}^{-2} \mathrm{~s}^{-1}$, bem inferiores aos $13,81 \mu \mathrm{mol} \mathrm{CO} \mathrm{CO}^{-2} \mathrm{~s}^{-1}$ verificados na presente pesquisa.

A redução da eficiência de carboxilação (EC) indica que houve distúrbios metabólicos ocorridos em decorrência do estresse hídrico, como sugeriram Riekert Van Heerden e Krüger (2002). A redução da EC pode ter sido provocada por inibição não estomática da fotossíntese, pois, é sabido que a EC (velocidade com que o $\mathrm{CO}_{2}$ fixado é processado) é limitada principalmente pela disponibilidade de $\mathrm{CO}_{2}$ e pela quantidade e atividade enzimática (ANJOS et al., 2014). Como não foi verificada uma redução significativa da concentração de carbono intercelular (Ci) para os regimes hídricos testados (irrigado e sequeiro) e, principalmente, sem variações entre variedades (Tabela 3), se confirma então que houve uma inibição não estomática da fotossíntese em condições de estresse hídrico, como proposto por Quick et al. (1992).

As reduções da concentração de clorofila na presente pesquisa foram superiores aos valores observados por Carlin et al. (2012); os autores verificaram que houve redução de 38,5\% da clorofila $a$ na cultivar IAC91-5155 de cana-de-açúcar, com redução a água disponível no solo (70\% para $40 \%$ da capacidade de campo - CC). Entretanto, os dados do presente trabalho foram inferiores aos obtidos pelos mesmos autores para a clorofila $b$ e clorofila tolal $(a+b)$, que observaram que com o decréscimo da disponibilidade hídrica no solo (70\% CC para 40\% CC) houve acentuada redução nos teores das $b(39,3 \%)$ e total $(38,8 \%)$.

Gonçalves et al. (2010) observaram resultados semelhantes aos do presente trabalho, com uma redução de $33,5 \%$ no teor de clorofila total (Clo $a+b$ ) no desenvolvimento inicial da variedade RB92579 submetidas ao déficit hídrico, enquanto que os teores de carotenóides permaneceram inalterados, o que consideram que plantas com este comportamento podem ser classificadas como dotadas de eficientes sistemas de fotoproteção. No mesmo trabalho também foram constatadas reduções superiores a $40 \%$ nos teores das clorofilas $a, b$ (Clo $a$ e $b$ ) e total (Clo $a+b)$ quando as plantas foram submetidas a restrições hídricas mais severas. De acordo com Cha- 
Um e Kirdmanee (2009), a diminuição gradual dos teores dos pigmentos de clorofila causada pelo estresse hídrico em plantas de cana-de-açúcar é um dos principais fatores que limitam a atividade fotossintética, comprometendo a produtividade da cultura pela dificuldade em alocar fotoassimilados.

Tal redução pode ser atribuída às mudanças na proporção de proteínas e lipídeos do complexo pigmento-proteína, ou ainda devido ao aumento da atividade da clorofilase, enzima que degrada as moléculas de clorofila existentes, o que pode ser explicado pela degradação de clorofila que é uma das consequiências do estresse hídrico, resultante da fotoinibição e do fotobranqueamento, que por sua vez serve como uma medida rápida usada como indicador do estresse hídrico (LONG et al., 1990). Além disso, Carlin et al. (2012) afirmam que a baixa disponibilidade hídrica no solo interfere na quantidade de nitrogênio da planta, limitando seu crescimento, influenciando diretamente a fotossíntese, seja na formação dos cloroplastos, síntese de clorofilas, síntese protéica ou atividade da enzima Rubisco, o que pode provocar a redução das clorofilas. De maneira geral, a restrição hídrica nas plantas da presente pesquisa, promoveu decréscimos significativos nos teores da clorofila $a$, sem, no entanto, promover qualquer diferença na razão clorofila $a / b$ que foi de 3,12 para o tratamento irrigado, e 3,10 para o sequeiro, como propuseram Carlin et al. (2012). Silva et al. (2007) também observaram que cultivares de cana-de-açúcar sob deficiência hídrica no solo apresentaram redução gradual no conteúdo dos pigmentos clorofilianos, de acordo com outros fatores como: severidade do estresse submetido, permanência da planta sob estresse e com o grau de tolerância e/ou sensibilidade da cultura.

No geral, sob estresse hídrico, o acúmulo de prolina livre nas folhas das variedades de cana-de-açúcar avaliadas, assim como os índices de clorofila $a$ (Clo $a)$ e total $($ Clo $a+b)$ podem ser utilizadas como indicadores do estresse hídrico, como sugerido por Carlin e Santos (2009). Para os parâmetros de trocas gasosas, o fechamento parcial dos estômatos, que pode ser observado através da diminuição da taxa de transpiração $(\mathrm{E})$, condutância estomática $\left(\mathrm{g}_{\mathrm{s}}\right)$, e a redução da fotossíntese (A), indicam a existência de mecanismos de adaptação das variedades de cana-de-açúcar, com a finalidade de reduzir as perdas de água, e maximizar a eficiência do uso desta sob condição de estresse hídrico moderado. 


\subsection{CONCLUSÕES}

A variedade RB855156 apresentou a maior concentração de prolina livre quando em condições de sequeiro, o que pode estar relacionado ao seu maior grau de tolerância ao estresse hídrico.

O acúmulo de prolina livre nas folhas e a redução dos índices de clorofila $a$ (Clo $a)$ e total (Clo $a+b)$ indicaram que as variedades RB835486, RB855156 e RB867515 são tolerantes ao estresse hídrico. Entretanto, a variedade RB835486 não respondeu bem às condições irrigadas (100\% da ETc) e ao período chuvoso da Região do Centro-Oeste.

As variedades de cana-de-açúcar RB835486, RB855156 e RB867515 cultivadas em sistema de sequeiro apresentaram redução na transpiração $(\mathrm{E})$, condutância estomática $\left(\mathrm{g}_{\mathrm{s}}\right)$, fotossíntese líquida (A), eficiência da carboxilação (EC), clorofila $a$ (Clo $a$ ), clorofila total (Clo $a+b)$, e aumento da eficiência intrínseca do uso da água (EIUA) e da carboxilação (EC). 


\subsection{REFERÊNCIAS BIBLIOGRÁFICAS}

ABDUL JALEEL, C.; MANIVANNAN, P.; KISHOREKUMAR, A.; SANKAR, B.; GOPI, R.; SOMASUNDARAM, R.; PANNEERSELVAM, R. Alterations in osmoregulations, antioxidant enzymes and indole alkaloid levels in Catharanthus roseus exposed to water deficit. Colloids and Surfaces B: Biointerfaces, Amsterdam, v.59, p.150-157, 2007.

ANJOS, D. N.; VASCONCElOS, R. C.; MENDES, H. T. A.; CANGUSSU, A. C. V. Trocas gasosas em plantas de feijoeiro submetidas a fitorreguladores, NPK e micronutrientes. Revista Enciclopédia Biosfera, Goiânia, v.10, n.19, p.176-182, 2014

ASHRAF, M.; FOOLAD, M.R. Roles of glycine betaine and proline in improving plant abiotic stress resistance. Environmental and Experimental Botany, v.59, p.206-216, 2007.

BATES, L. S.; WALDREW, R. P.; TEARE, I. D. Rapid determination of free proline for waterstress studies. Plant Soil, Dordrecht, v.39, p.205-207, 1973.

BIDÓIA, M. A. P.; SANTOS, D. M. M.; MARIN, A.; LANDELL, M. G. A.; BANZATTO, D. A.; CAZETTA, J. O. Efeito da defi ciência hídrica no acúmulo de prolina livre em cana-de-açúcar, em diferentes períodos de desenvolvimento. Revista Stab, Piracicaba, v.24, p.6-9, 2006.

BORTOLO, D. P. G.; MARQUES, P. A. A.; PACHECO, A.C. Teor e rendimento de flavonóides em calêndula (Calendula officinalis L.) cultivada com diferentes lâminas de irrigação. Revista Brasileira de Plantas Medicinais, Botucatu, v.11, n.4, p.435-441, 2009.

BRASIL. MINISTÉRIO DA AGRICULTURA, PECUÁRIA E ABASTECIMENTO. Plano Nacional de Agroenergia: 2006-2011. 2.ed. Brasília: Embrapa Informação Tecnológica, 2006. $114 \mathrm{p}$.

CARLIN, S. D.; RHEIN, A. F. L.; SANTOS, D. M. M. Efeito simultâneo da deficiência hídrica e do alumínio tóxico no solo na cultivar IAC91-5155 de cana-de-açúcar. Semina: Ciências Agrárias, Londrina, v.33, n.2, p.553-564, 2012.

CARLIN, S. D.; SANTOS, D. M. M. Indicadores fi siológicos da interação entre defi cit hídrico e acidez do solo em cana-de-açúcar. Pesquisa Agropecuária Brasileira, Brasília, v.44, n.9, p.11061113, set. 2009.

CARLIN, S. D.; SILVA, M. A.; ROSSETTO, R. Parâmetros biométricos e produtividade da canade-açúcar após tombamento dos colmos. Bragantia, Campinas, v.67, n.4, p.845-853, 2008.

CHA-UM, S.; KIRDMANEE, C. Proline accumulation, photosynthetic abilities and growth characters of sugarcane (Saccharum officinarum L.) plantlets in response to iso-osmotic salt and water-deficit stress. Agricultural Sciences in China, v.8, n.1, p.51-58, 2009.

CHAVES, M. M.; FLEXAS, J.; PINHEIRO, C. Photosynthesis under drought and salt stress: regulation mechanisms from whole plant to cell. Annals of Botany, Oxford, v.103, p.551-560, 2008.

CONAB, Companhia Nacional de Abastecimento. Acompanhamento de safra brasileira: canade-açúcar, v.1-Safra 201/2015, n.1- Primeiro levantamento, abril/2014. Brasília: Conab, 2014. 20 p. 
CONFORTO, E. C.; CORNÉLIO, M. L.; ANDREOLI, R. P.; GONÇALVES, E. C. P.. Validação das unidades arbitrárias do teor de clorofilas obtido em folhas intactas de seringueira. Revista gro@mbiente, Boa Vista, v. 8, n. 2, p. 288-292, 2014.

COSTA, C. T. S.; FERREIRA, V. M.; ENDRES, L.; FERREIRA, D. T. R. G.; GONÇALVES, E. R.; Crescimento e produtividade de quatro variedades de cana-de-açúcar no quarto ciclo de cultivo. Revista Caatinga, Mossoró, v. 24, n. 3, p. 56-63, 2011.

DANTAS NETO, J.; FIGUEIRÊDO, J. L. C.; FARIAS, C. H. A.; AZEVEDO, H. M.; AZEVEDO, C. A. V. Resposta da cana-de-açúcar, primeira soca, a níveis de irrigação e adubação de cobertura. Revista Brasileira de Engenharia Agrícola e Ambiental, Campina Grande, v.10, n.1, p.283-288, 2006.

DAROS, E.; OllVEIRA, R. A.; ZAMBON, J. L. C.; FILHO, J. C. B. Catálogo nacional de variedades "RB" de cana-de-açúcar. Curitiba: Ridesa, 2010.136 p.

DILLEWIJN, C.V. Botany of sugarcane. Waltham: Chronica Botânica, 1952. 371 p.

FARQUHAR, G.D.; SHARKEY, T.D. Stomatal conductance and photosynthesis. Annual Review of Plant Physiology, Palo Alto, v.33, p. 317-345, 1982.

FERRAZ, R. L. S.; MELO, A. S.; SUASSUNA, J. F.; BRITO, M. E. B.; FERNANDES, P. D.; NUNES JÚNIOR, E. S. Trocas gasosas e eficiência fotossintética em ecótipos de feijoeiro cultivados no semiárido. Revista Pesquisa Tropical, Goiânia, v.42, n.2, p.181-188, 2012.

GIANNAKOULA, A.; MOUSTAKAS, M.; MYLONA, P.; PAPADAKIS, I.; YUPSANIS, T. Aluminum tolerance in maize is correlated with increased levels of mineral nutrients, carbohydrates and proline, and decreased levels of lipid peroxidation and Al accumulation. Journal of Plant Physiology, Stuttgartv.165, p.385-396, 2008.

GONÇALVES, E. R,.; FERREIRA, V. M.; SILVA, J. V.; ENDRES, L.; BARBOSA, T. P.; DUARTE, W. G. Trocas gasosas e fluorescência da clorofila a em variedades de cana-de-açúcar submetidas à deficiência hídrica. Revista Brasileira de Engenharia Agrícola e Ambiental. Campina Grande, v.14, n.4, p.378-386, 2010.

HANKS, R. J.; RASMUSSEN, V. P.; WILSON, G. D. Line-source sprinkler for continuous variable irrigation crop production studies. Soil Science Society of America Journal. Madison, v. 40, p. 426-429, 1976.

HENDRY, G. A., F.; GRIME, J. P. (Eds.). Methods in comparative plant ecology. New York: Marcel Dekker, 282 p., 1993.

INMAN-BAMBER, N. G.; BONNETT, G. D; SPILLMAN, M. F.; HEWITT, M. L.; JACKSON, J. Increasing sucrose accumulation in sugarcane by manipulating leaf extension and photosynthesis with irrigation. Australian Journal of Agricultural Research, Victoria v.59, p.13-26, 2008.

INMAN- BAMBER, N. G.; SMITH, D. M. Water relations in sugarcane and response to water deficits. Field Crops Research, Amsterdam, v.92, p.185- 202, 2005.

KISHOR, P. B. K.; SANGAM, S.; AMRUTHA, R. N.; LAXMI, P. S.; NAIDU, K. R.; RAO, K. R. S. S.; RAO, S.; REDDY, K. J.; THERIAPPAN, P.; SREENIVASULU, N. Regulation of proline 
biosynthesis, degradation, uptake and transport in higher plants: its implications in plant growth and abiotic stress tolerance. Current Science, Bangalore, v.88, n.3, p.424-438, 2005.

LONG S. P.; FARAGE, P. K.; GROOME, K.; MACHARIA, J. M. N.; BAKER, N. R. Damage to photosynthesis during chilling and freezing and its significance to the photosynthetic productivity of field crops. In: BALTSCHEFFSKY M (Ed). Current Research in Photosynthesis. Dordrecht: Kluwer Academic Publishers, 1990. Vol.4, p.835-842.

MACHADO, R. S.; RIBEIRO, R. V.; MARCHIORI, P. E. R.; MACHADO, D. F. S. P.; MACHADO, E. C.; LANDELL, M. G. A. Respostas biométricas e fisiológicas ao déficit hídrico em cana-de-açúcar em diferentes fases fenológicas. Pesquisa Agropecuária Brasileira, Brasília, v.44, n.12, p.1575-1582, 2009.

MARIN, A.; SANTOS, D. M. M. Interação da defi ciência hídricave da toxicidade do alumínio em guandu cultivado em hidroponia. Pesquisa Agropecuária Brasileira, Brasília, v.43, p.1267-1275, 2008.

MOURA, L. C.; SILVA, N. F.; CUNHA, F. N.; BASTOS, F. J. C.; CÉLIA, J. A.; TEIXEIRA, M. B. Índice de maturação da cana-de-açúcar fertirrigada sobre diferentes lâminas. Revista Brasileira de Agricultura Irrigada, Fortaleza, v.8, n.1, p.64-76, 2014.

NOGUEIRA, R. J. M. C. MORAES, J. A. P. V.; BURITY, H. A.; BEZERRA NETOA, E. Alterações na resistência à difusão de vapor das folhas e relações hídricas em aceroleiras submetidas a déficit de água. Revista Brasileira de Fisiologia Vegetal, Campinas, v 13, n.1, p.755-87, 2001.

MONTEITH, J. L. Evaporation and Environment. 19th Symposia of the Society for Experimental Biology, University Press, Cambridge, v. 19, p.205-234, 1965.

OLIVEIRA, M. A. J.; BOVI, M. L. A.; MACHADO, E. C.; GOMES, M. M. A.; HABERMANN, G.; RODRIGUES, J. D. Fotossíntese, condutância estomática e transpiração em pupunheira sob deficiência hídrica. Scientia Agricola, Piracicaba, v.59, n.1, p.59-63, jan./mar. 2002.

PARDOS, J. A. Respuestas de las plantas al anegamiento del suelo. Sistemas y Recursos Forestales, s.n., p.101-7, 2004.

PIZARD, A.; ALYARI, H.; SHAKIBA, M. R.; ZEHTAB-SALMASI, S. MOHAMMADI, A. Essential oil content and composition of german chamomile (Matricaria chamomilla L.) at different irrigation regimes. Journal of Agronomy, v.5, n.3, p.451-5, 2006.

PUGNAIRE, F. I.; ENDOLZ, L. S.; PARDOS, J. Constraints by water stress on plant growth. In: PESSARAKLI, M. (Ed.). Handbook of plant and crop Stress. New York: Dekker, 1994. p.247259.

QUEIROZ, R. J. B.; SANTOS, D. M. M.; CARLIN, S. D.; MARIN, A.; BANZATTO, D. A.; CAZETTA, J. O. Osmoprotetores em cana-de-açúcar sob efeito da disponibilidade hídrica no solo. Científica, Jaboticabal, v.36, n.2, p.107 - 115, 2008

QUICK, W. P.; CHAVES, M. M.; WENDLER, R.; DAVID, M.; RODRIGUES, M. L.; PASSARINHO, J. A.; PEREIRA, J. S.; ADCOCK, M. D.; LEEGOOD, R. C.; STITT, M. The effect of water stress on photosynthetic carbon metabolism in four species grown under field conditions. Plant, Cell and Environment, v.15, p.25-35, 1992. 
RIEKERT VAN HEERDEN, P. D.; KRÜGER, G. H. J. Separately and simultaneously induced dark chilling and drought stress effects on photosynthesis, proline accumulation and antioxidant metabolism in soybean. Journal of Plant Physiology, Stuttgart, v.159, n. 10, p.1077-1086, 2002.

SANO. S. M.; ALMEIDA, S. P.; RIBEIRO, J. F. Cerrado: ecologia e flora. Embrapa Cerrados. Brasília: Embrapa Informação Tecnológica, 2008. 2v. 1279 p.

SHARMA, P.; DUBEY, R. S. Modulation of nitrate reductase activity in rice seedlings under aluminium toxicity and water stress: role of osmolytes as enzyme protectant. Journal of Plant Physiology, Stuttgart, v. 162, n. 8, p. 854-862, 2005.

SILVA, M. A.; JIFON, J. L.; SILVA, J. A. G.; SHARMA, V. Use of physiological parameters as fast tools to screen for drought tolerance in sugarcane. Brazilian Journal of Plant Physiology, Londrina, v.19, n.3, p.193-201, 2007.

SILVA, M. A.; JIFON, L.; SILVA, J. A. C.; SHARMA, V. Use of physiological parameters as fast tools to screen for drought tolerance in sugarcane. Brazilian Journal of Plant Physiology, Londrina, v. 19, n. 3, p. 193-201, 2007.

SILVA, M. A.; SILVA, J. A. G.; ENCISO, J.; SHARMA, V.; JIFON, J. Yield components as indicators of drought tolerance of sugarcane. Scientia Agricola, Piracicaba, v.65, p.620-627, 2008. SILVA, S. R. S.; DEMUNER, A. J.; BARBOSA, L. C. A.; CASALI, V. W. D.; NASCIMENTO, E. A.; PINHEIRO, A. L. Efeito do estresse hídrico sobre características de crescimento e a produção de óleo essencial de Melaleuca alternifolia Cheel. Acta Scientiarum, Maringá, v.24, n.5, p.1363-8, 2002.

SMIT, M. A.; SINGELS, A. The response of sugarcane canopy development to water stress. Field Crops Research, Amsterdam, v.98, p.91-97,2006.

SOUZA, R. P.; MACHADO, E. C.; SILVA, J. A. B.; LAGÔA, A. M. M. A.; SILVEIRA, J. A. G. Photosynthetic gas exchange, chlorophyll fluorescence and some associated metabolic changes in cowpea (Vigna unguiculata) during water stress and recovery. Environmental and Experimental Botany, Oxford, v.51, p. 45-56, 2004.

TAIZ, L.; ZEIGER, E. Fisiologia Vegetal. 5. ed. Porto Alegre: Artmed, 2013. 918p.

THERIAPPAN, P.; SREENIVASULU, N. Regulation of proline biosynthesis, degradation, uptake and transport in higher plants: its implications in plant growth and abiotic stress tolerance. Current Science, Bangalore, v.88, p.424-438, 2005.

YORDANOV, I.; VELIKOVA, V.; TSONEV, T. Plant response to drought, acclimation, and stress tolerance. Photosynthetica, Prague, v.38, n.1, p.171-186, 2000. 


\section{CONSIDERAÇÕES FINAIS}

$\mathrm{Na}$ avaliação biométrica foi possível verificar que a variedade RB867515 foi a que apresentou maiores valores biométricos de diâmetro médio do colmo (DMC), altura média do perfilho (AMP), tanto em cultivo irrigado como em sequeiro. A área foliar respondeu de forma a reduzir o número de folhas verdes completamente abertas (NFVA), e as dimensões foliares (comprimento e largura da folha +3 ) diminuindo conseqüentemente a área foliar das plantas. Resultados que confirmam que no período de intenso déficit hídrico as plantas tendem a reduzir a superfície foliar para evitar perdas excessivas de água por transpiração, havendo a recuperação do crescimento nas três variedades testadas logo após a retomada da precipitação pluviométrica, podendo ser variável de acordo com cada genótipo.

As variedades RB835486, RB855156 e RB867515 de cana-de-açúcar quando cultivada com irrigação equivalente a $75 \%$ da ETc não proporcionou diferença significativa para a qualidade tecnológica entre elas em relação ao cultivo em sequeiro ( $0 \%$ da ETc), demonstrando que podem ser exploradas no cultivo de sequeiro na região do Cerrado. Porém, as variedades RB867515 e a RB855156 foram as que obtiveram maior produtividade média, com 174,99 e 148,10 $\mathrm{Mg} \mathrm{ha}^{-1}$, respectivamente, superando a produtividade média nacional de 73,6 $\mathrm{Mg} \mathrm{ha}^{-1}$; sendo a variedade RB867515 a que obteve maior peso médio de colmo, com média de 2,06 kg colmo ${ }^{-1}$.

A variedade RB855156 apresentou a maior concentração de prolina livre quando em condições de sequeiro, o que pode estar relacionado ao seu maior grau de tolerância ao estresse hídrico. O acúmulo de prolina livre nas folhas e a redução dos índices de clorofila $a$ (Clo $a$ ) e total $($ Clo $a+b)$ indicaram que as variedades RB835486, RB855156 e RB867515 são tolerantes ao estresse hídrico. Entretanto, a variedade RB835486 não respondeu bem às condições irrigadas (100\% da ETc) e ao período chuvoso da Região do Centro-Oeste, que provavelmente pode ter sido devido a sua sensibilidade a áreas de altitudes elevadas.

As variedades de cana-de-açúcar RB835486, RB855156 e RB867515 cultivadas em sistema de sequeiro apresentaram redução na transpiração $(\mathrm{E})$, condutância estomática $\left(\mathrm{g}_{\mathrm{s}}\right)$, fotossíntese líquida (A), eficiência da carboxilação (EC), clorofila $a$ (Clo $a$ ), clorofila total (Clo $a+b$ ), e aumento da eficiência intrínseca do uso da água (EIUA) e da carboxilação (EC). As plantas podem evitar o estresse hídrico pela diminuição da transpiração através do fechamento dos estômatos e da área foliar exposta, pois as folhas jovens da cana-de-açúcar são capazes de se enrolar para reduzir sua área foliar projetada. Além do mais, a variedade RB867515 possui mecanismos fisiológicos para evitar a perda excessiva de água quando submetida ao déficit hídrico, onde as características fisiológicas deste genótipo sob sequeiro podem ser devido a uma maior eficiência da abertura estomática, como constatado em tais valores, o que caracteriza uma maior tolerância ao déficit hídrico quando comparada a demais variedades testadas. 
As variedades RB855156 e RB867515 se mostraram mais tolerantes as condições ambientais do Cerrado brasileiro, apresentando produtividade satisfatória para o quarto ciclo de cultivo da cultura e não havendo perdas significativas na qualidade tecnológica do caldo mesmo cultivada em regime de sequeiro, onde naturalmente existe a tendência de declínio do potencial produtivo dos genótipos, o que reforçam ainda mais que, mesmo com o declínio natural do ciclo, as variedades avaliadas, com exceção da RB835486, apresentam boa adaptabilidade às condições climáticas da Região Centro-Oeste do Brasil, assim como a potencialidade dessa Região para o setor sucroalcooleiro no País. 


\section{ANEXOS}

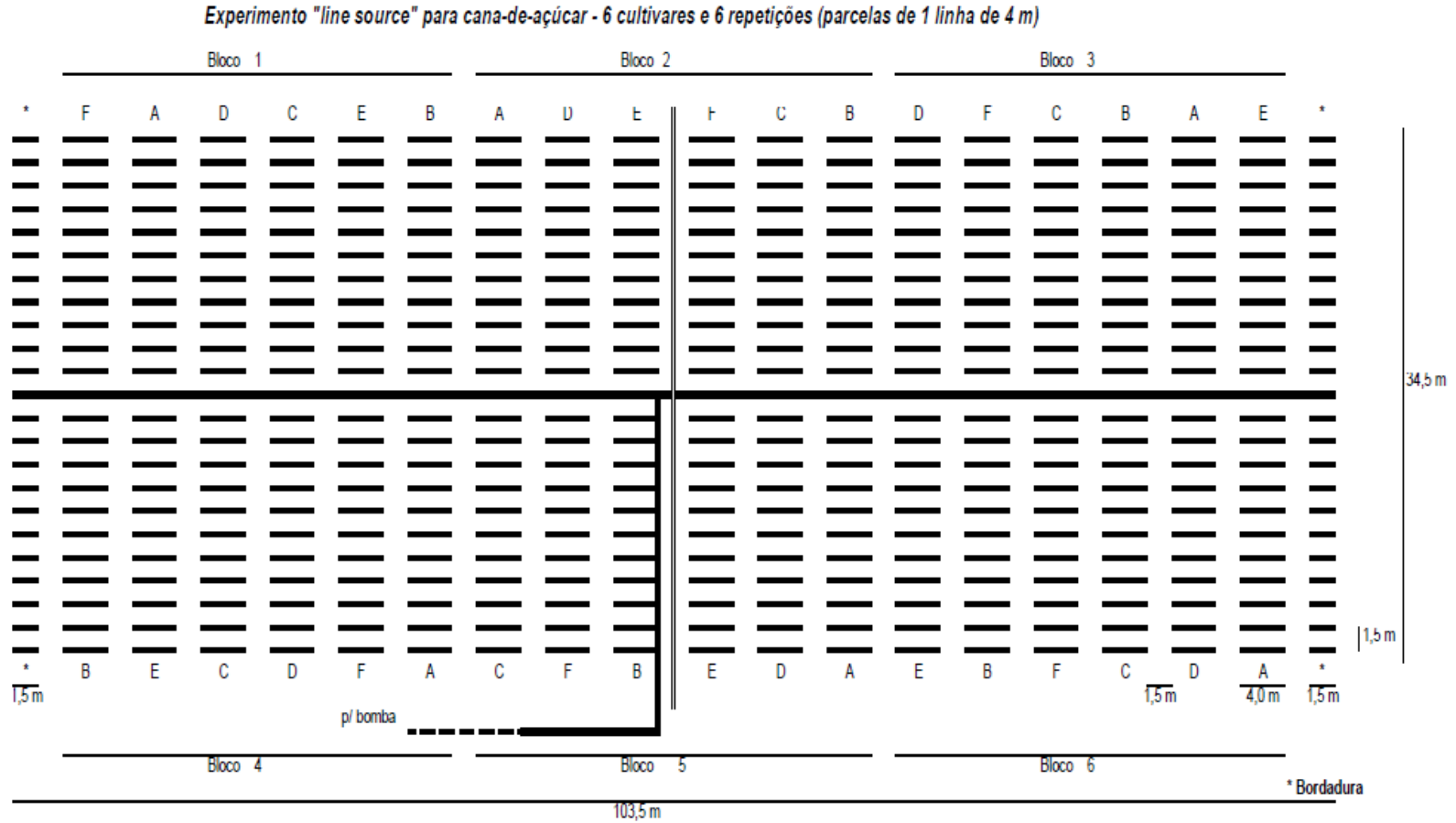

Figura 1A. Croqui da área do experimento, a letra "A" indica a posição da RB855156, a letra "B" indica a posição da RB835486 e a "C" indica a posição da RB867515 na área experimental.

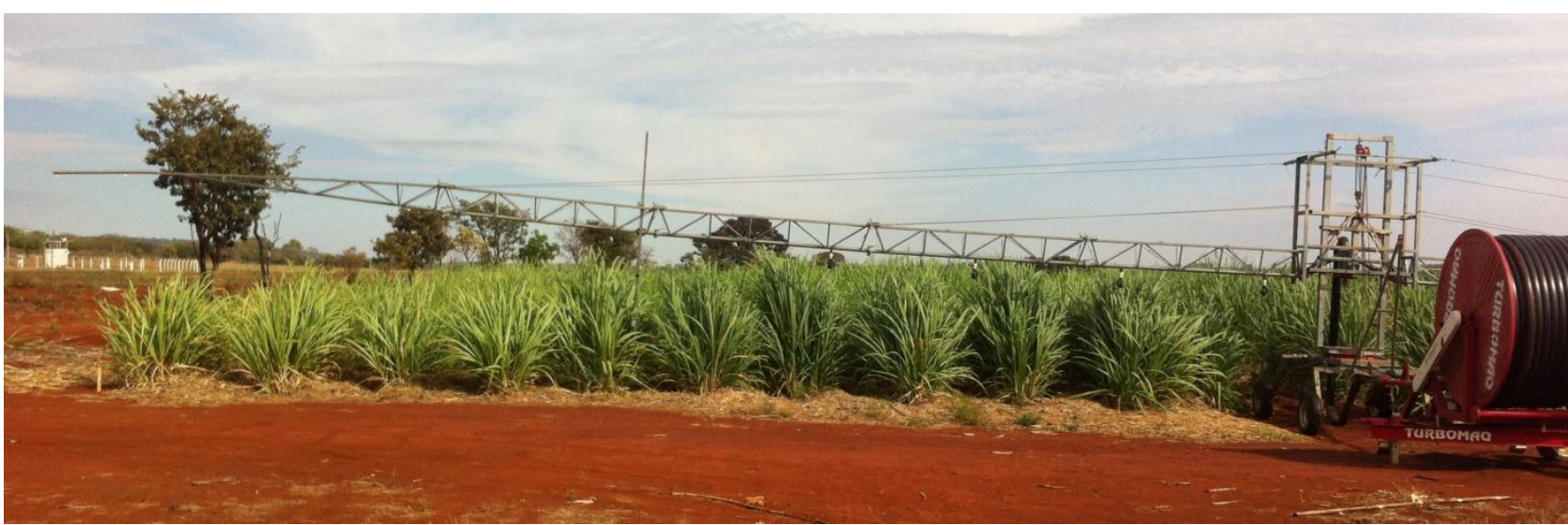

Figura 2A. Barra irrigadora com sistema autopropelido e bocais conjugados (Line Source Sprinkler System). Embrapa Cerrados, Planaltina-DF (2013). 


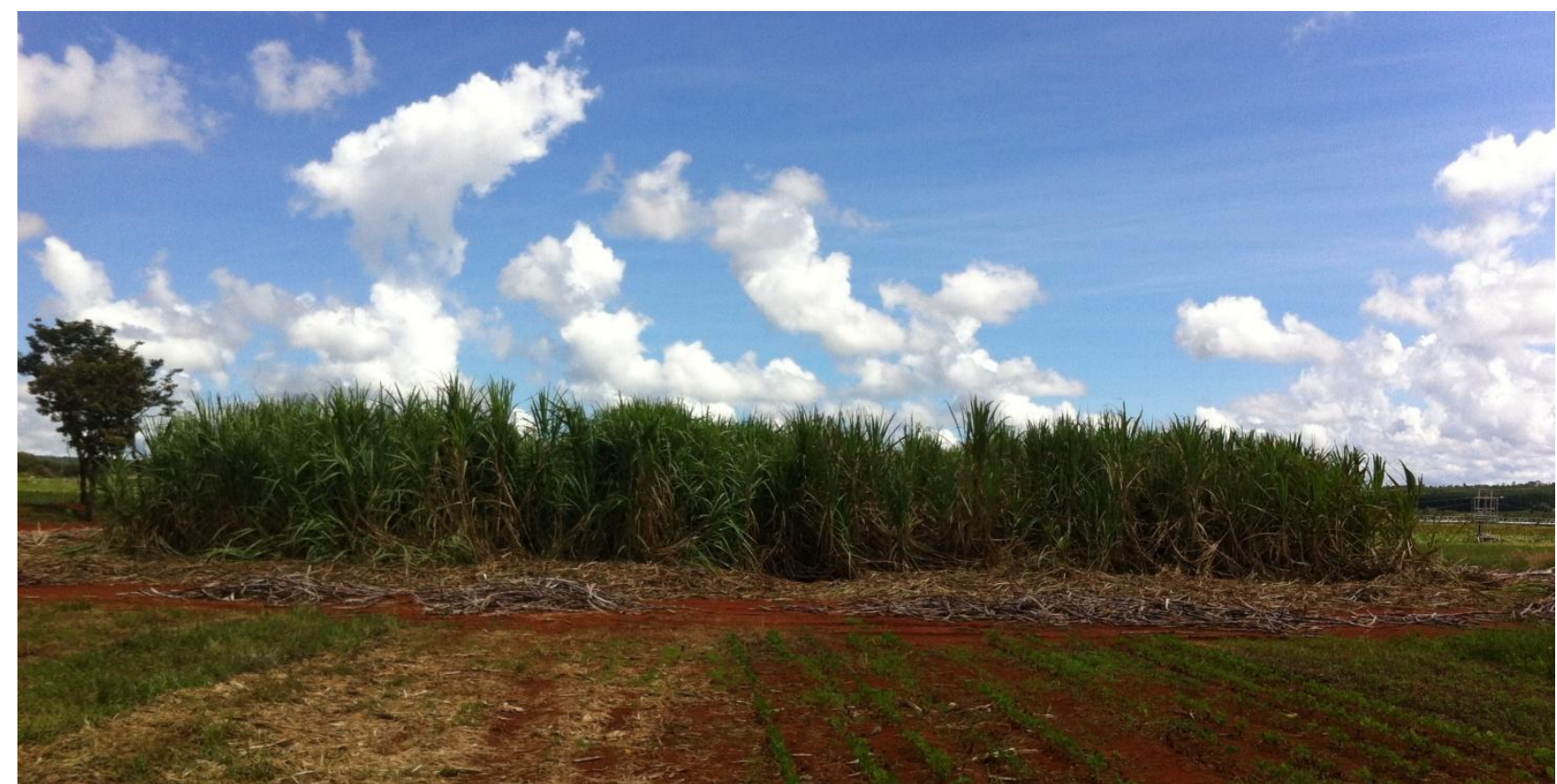

Figura 3A. Érea experimental após a retomada das precipitações, ainda era possível observar diferenças entre os regimes hídricos irrigado e sequeiro. Foto tirada antes da colheita. Embrapa Cerrados, Planaltina-DF (2013).

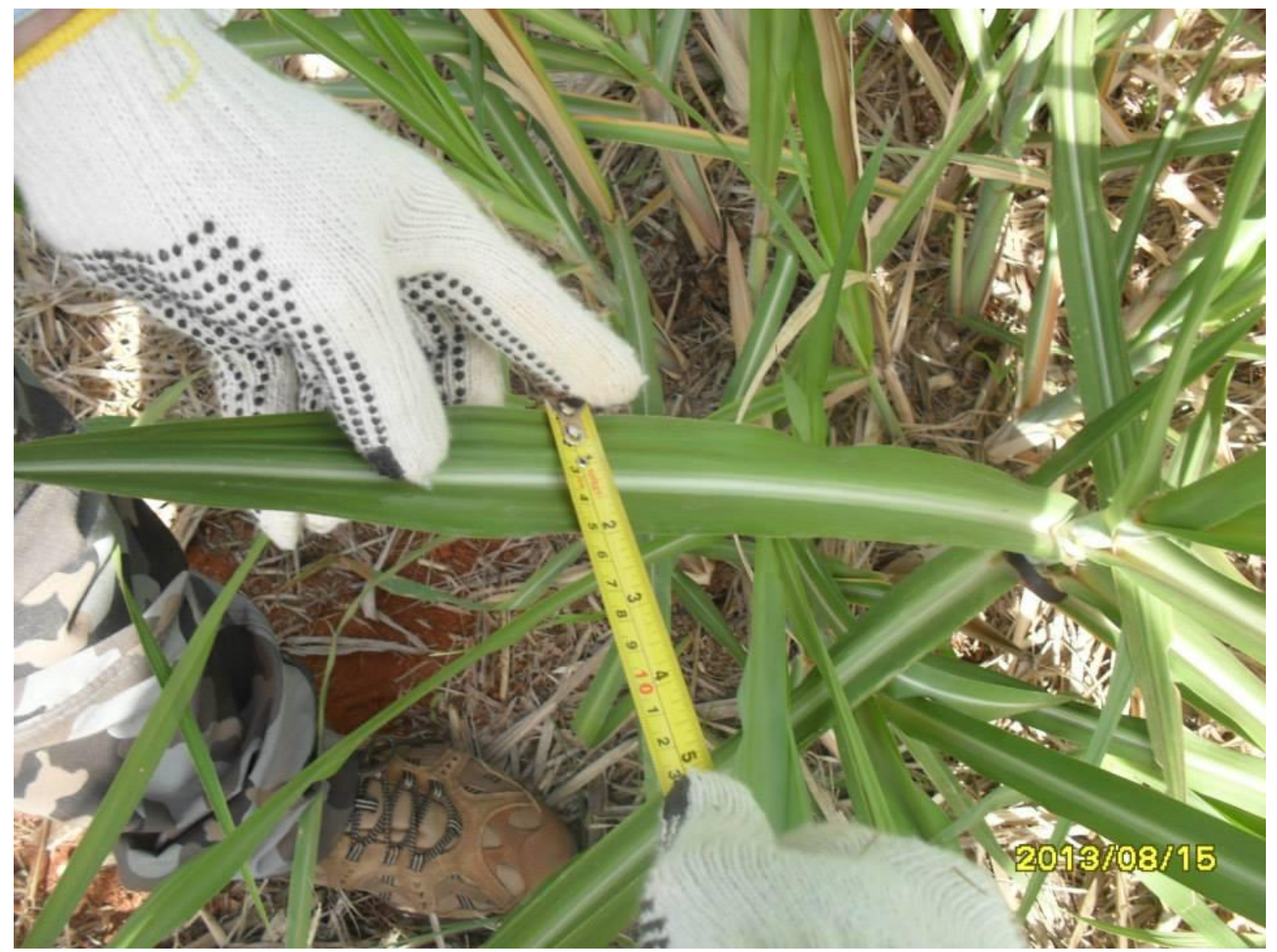

Figura 4A. Mensuração do comprimento e da largura da folha +3. Embrapa Cerrados, Planaltina-DF (2013). 


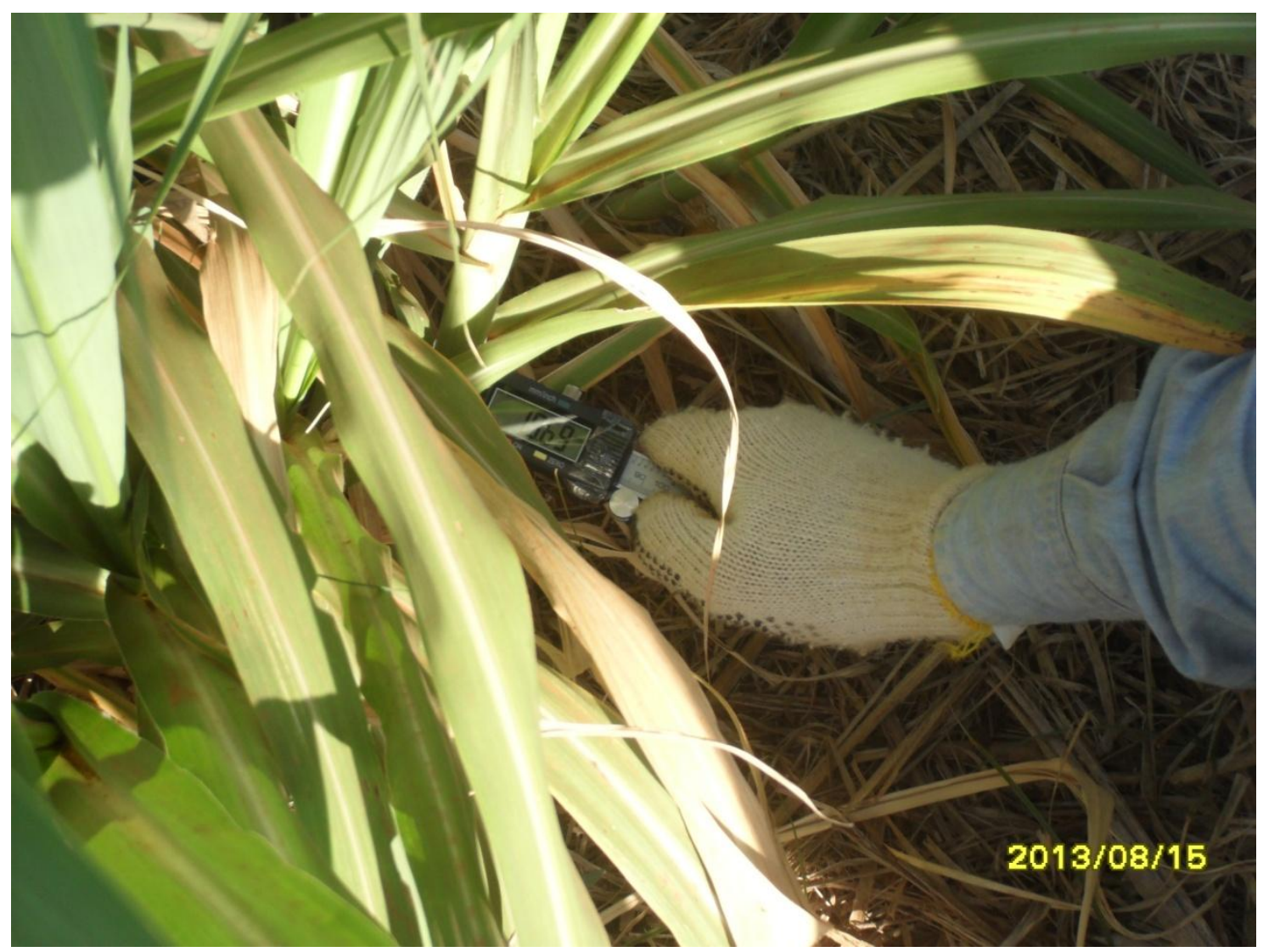

Figura 5A. Mensuração do DMC das variedades com o auxílio de um paquímetro digital. Embrapa Cerrados, Planaltina-DF (2013).

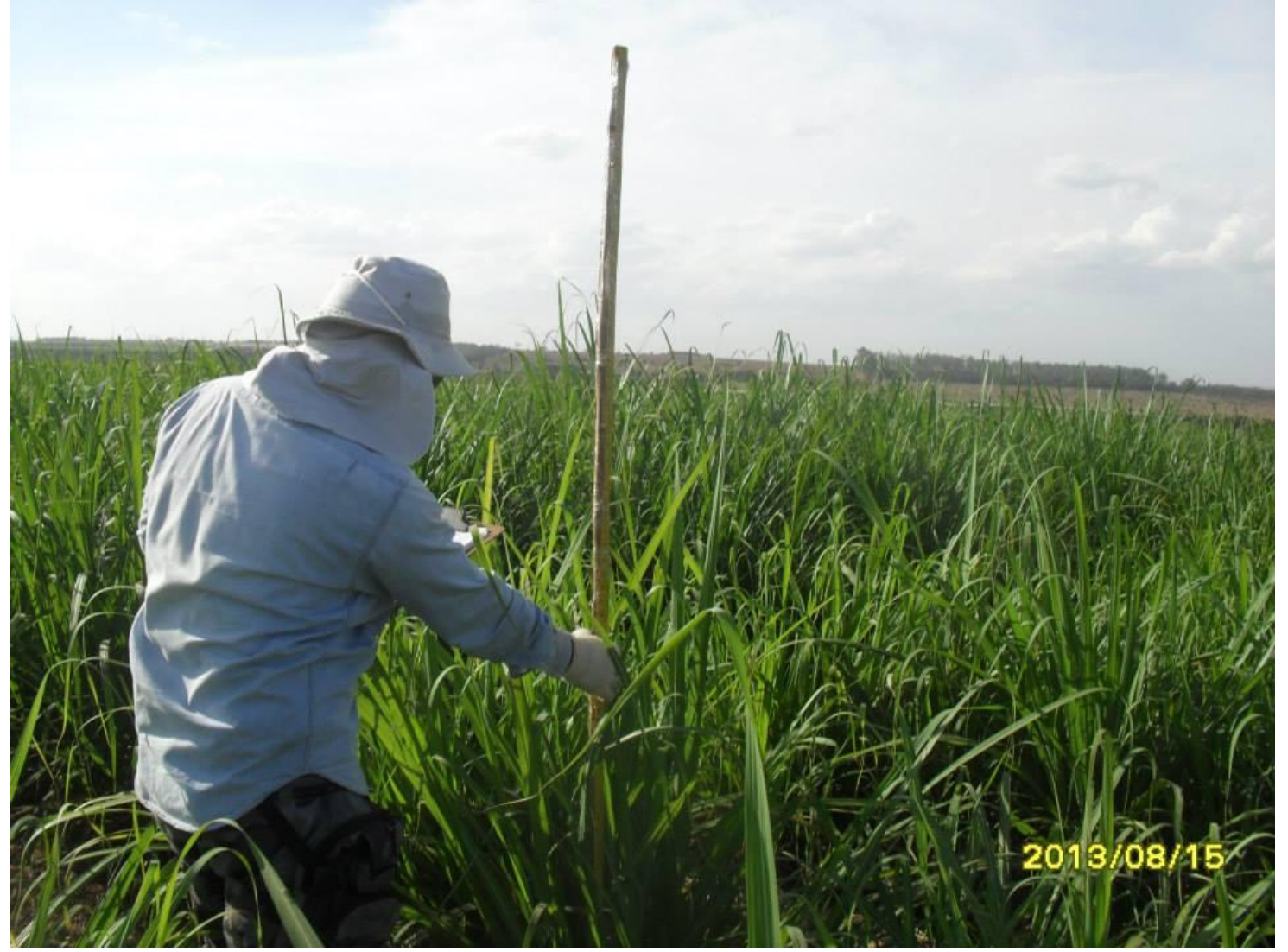

Figura 6A. Mensuração da EMC em diferentes períodos. Embrapa Cerrados, Planaltina-DF (2013). 


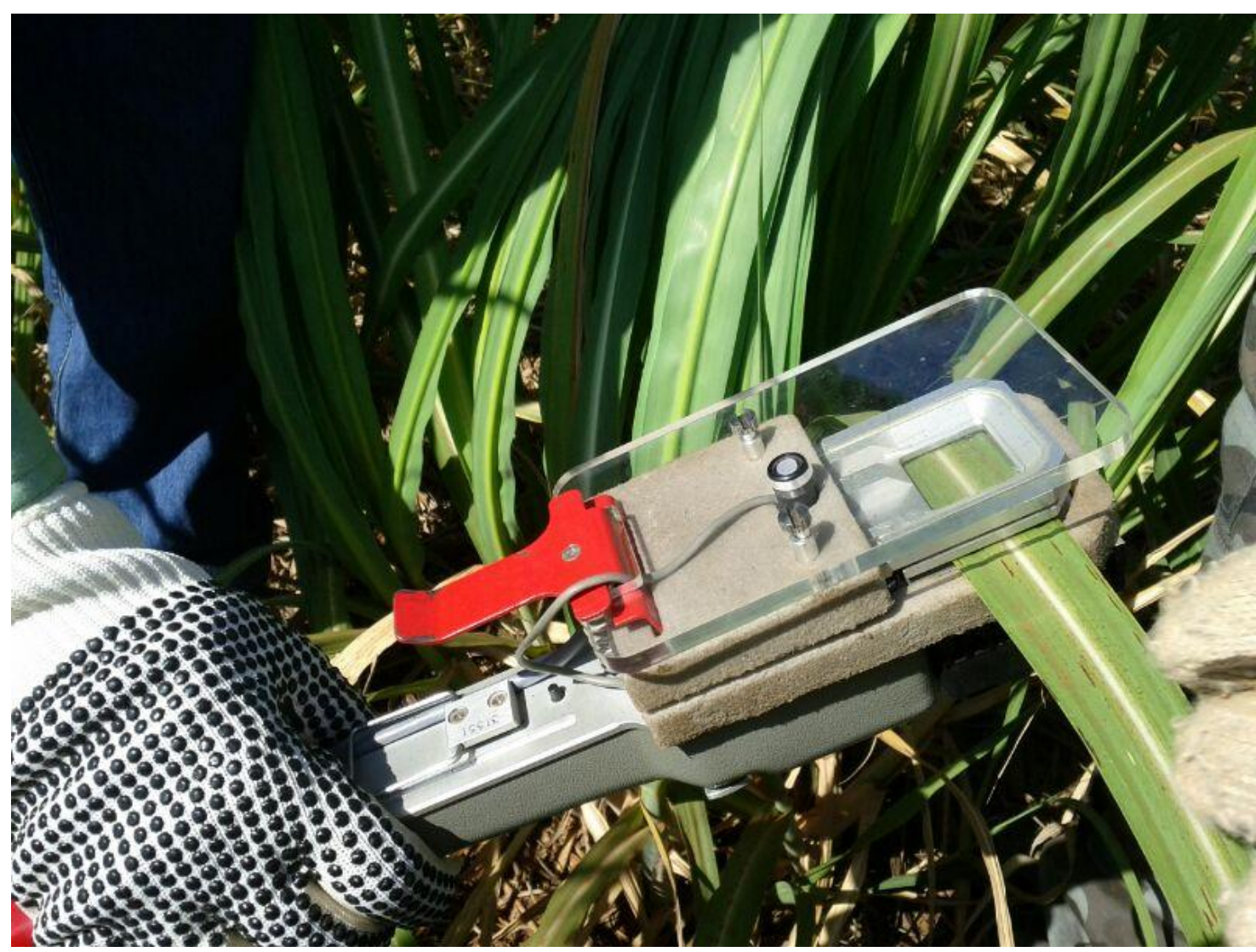

Figura 7A. Avaliação dos parâmetros fotossintéticos utilizando o aparelho de medição de trocas gasosas "Irga". Embrapa Cerrados, Planaltina-DF (2013).

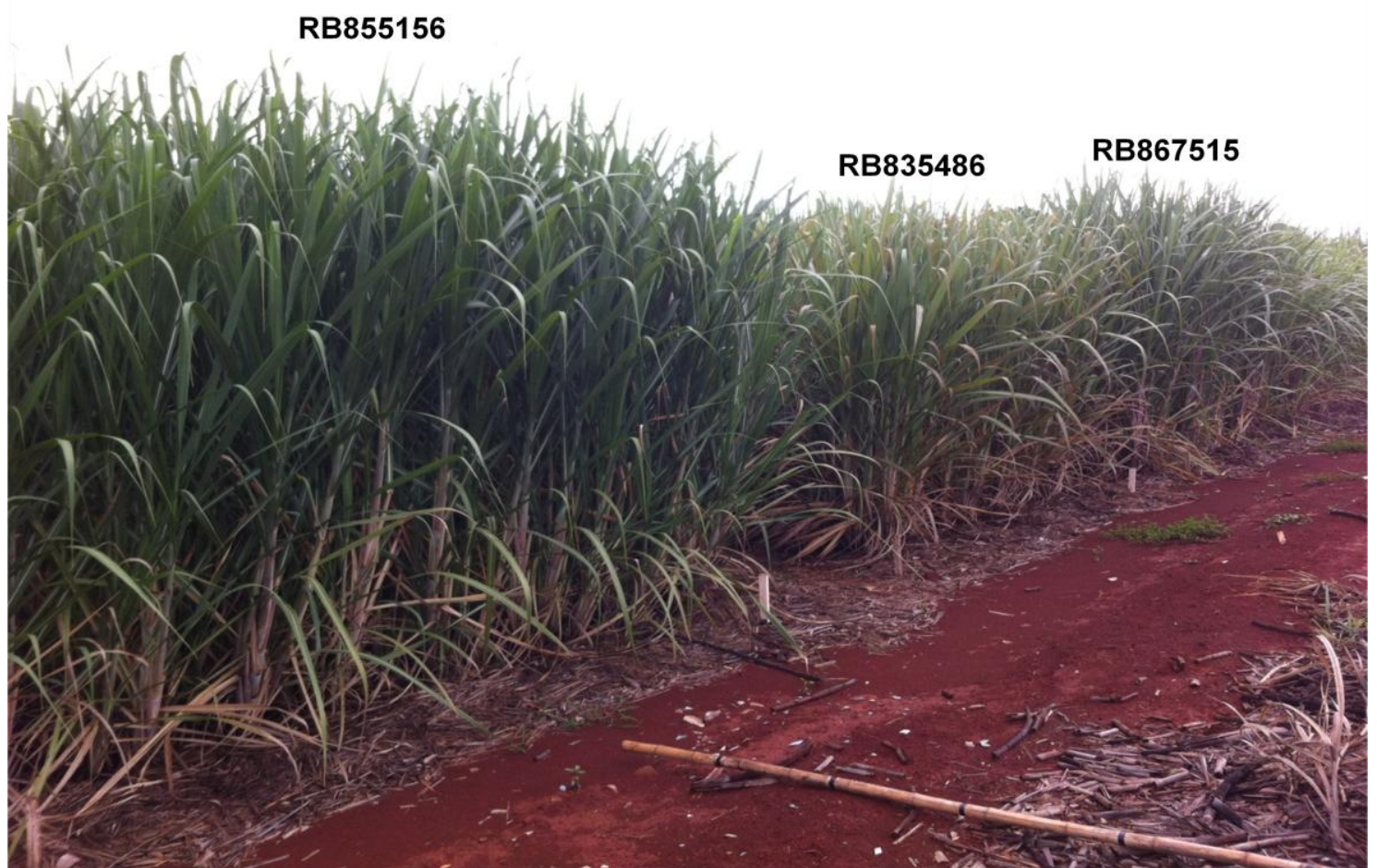

Figura 8A. Diferença da EMC das três variedades avaliadas após a retomada das precipitações. Foto tirada antes da colheita. Embrapa Cerrados, Planaltina-DF (2013). 


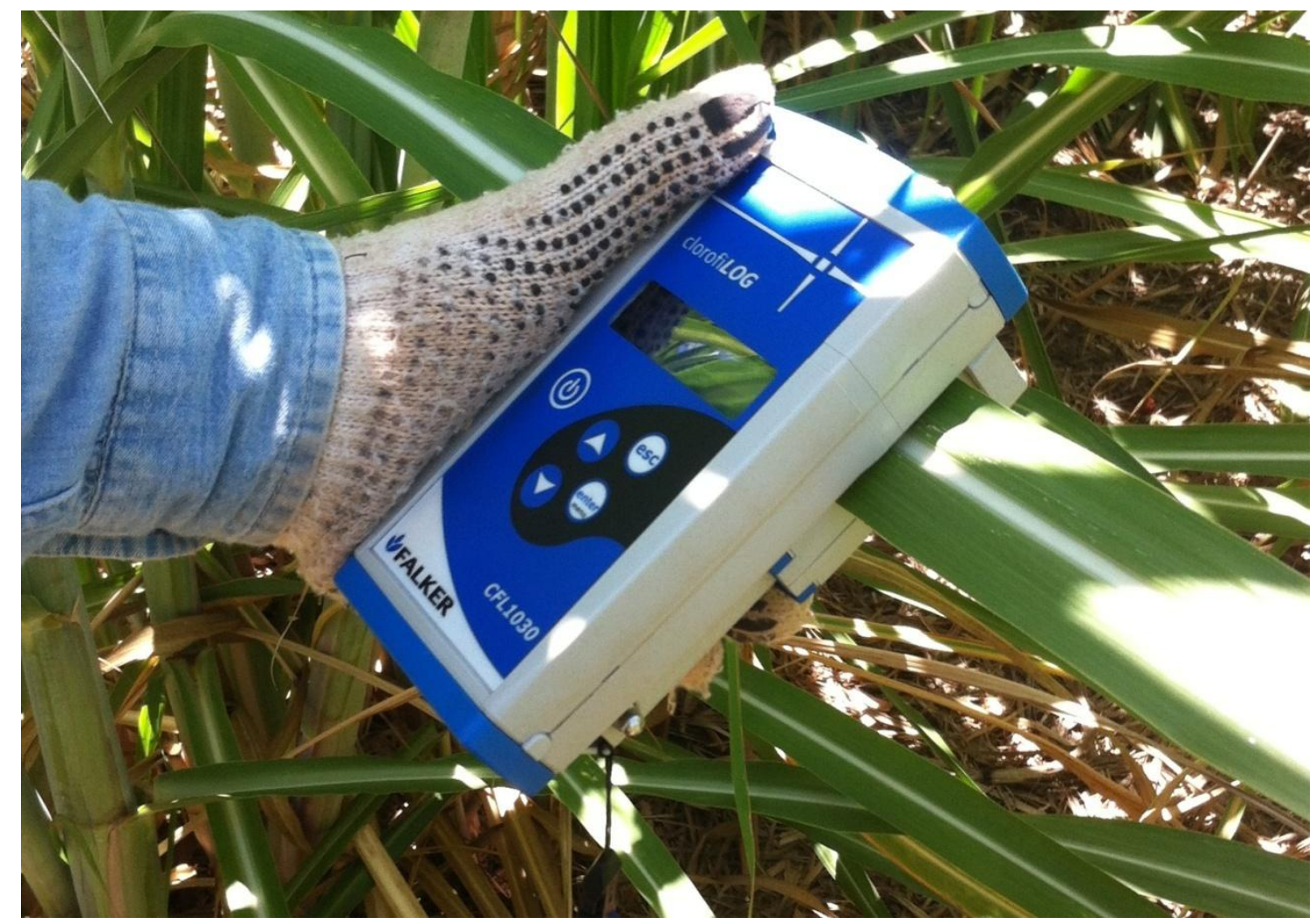

Figura 9A. Mensuração do teor de clorofila $a$ e clorofila $b$ com o auxílio de um medidor eletrônico de clorofila, modelo ClorofiLOG (Falker, CFL-1030). Embrapa Cerrados, Planaltina-DF (2013).

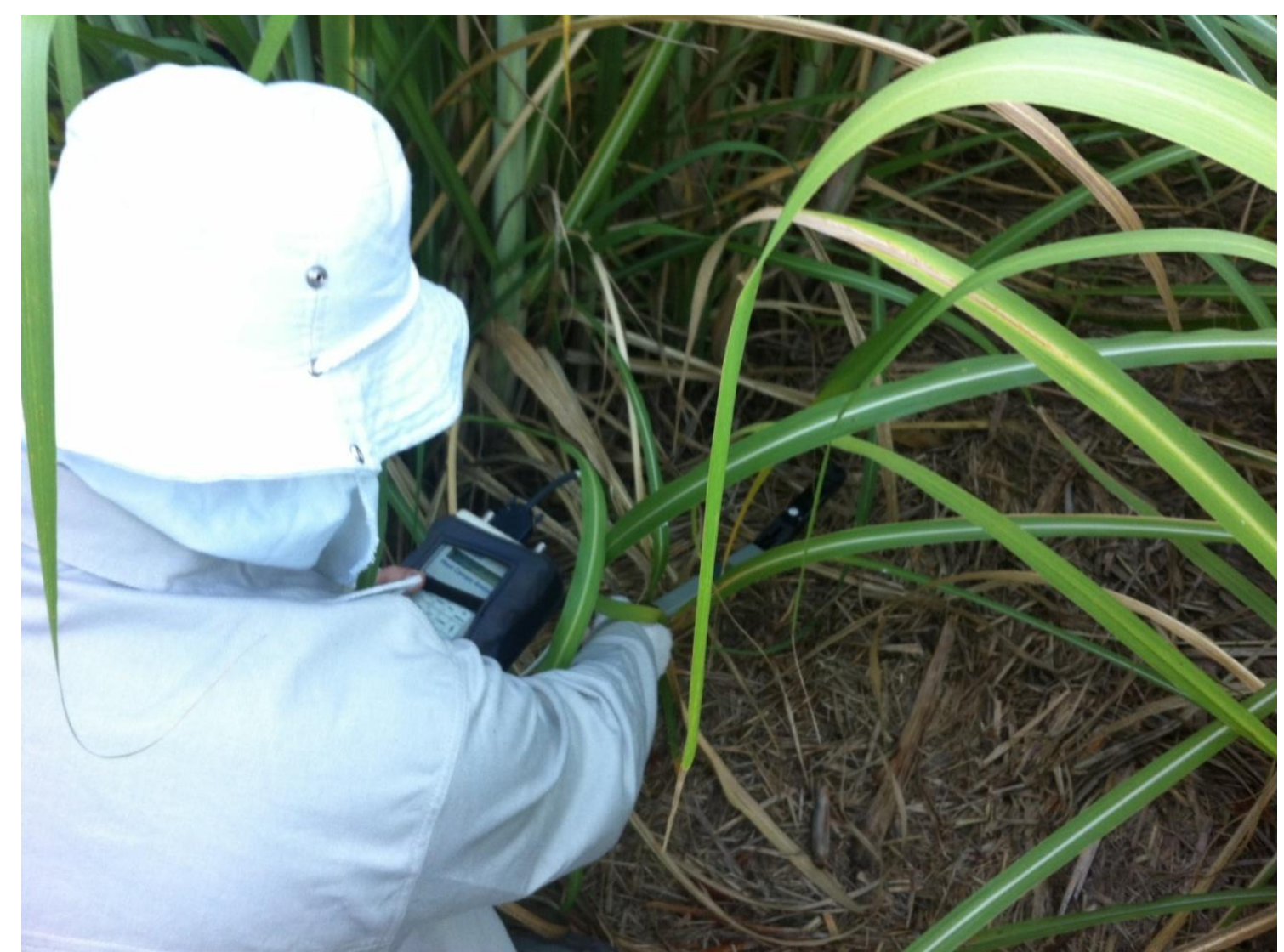

Figura 10A. Mensuração do índice de área foliar (IAF) com auxílio de um LAI-2000 Plant Canopy Analyzer (LI-COR® Biosciences). Embrapa Cerrados, Planaltina-DF (2013). 


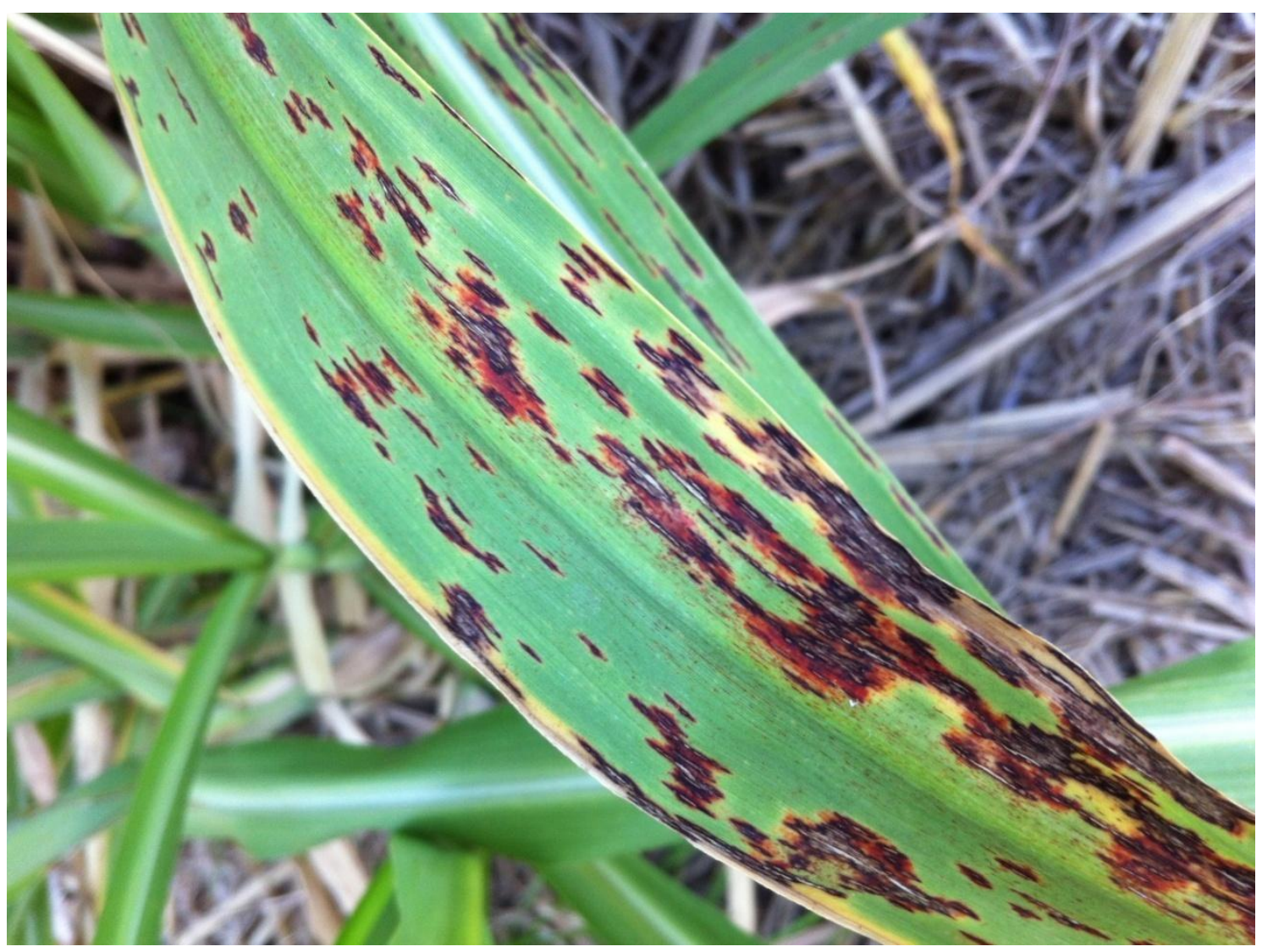

Figura 11A. Detalhe da folha com incidência da podridão vermelha, causada pelo ataque do agente etiológico Colletotrichum falcatum na variedade RB835486. Embrapa Cerrados, Planaltina-DF (2013). 